SF 257

A47 




U. S. DEPARTMENT OF AGRICULTURE, BUREAU OF. ANIMAL INDUSTRY - BULLETIN No. 46.

D. E. SALMON, D. V. M., Chief of Bureau.

\title{
THE MILK SUPPLY
}

\section{TWO HUNDRED CITIES AND TOWNS.}

\author{
HENRY E. ALVORD, C. E., \\ CHIEF OF DAIRY DIVISION,
}

AND

R. A. PEARSON, M. S., ASSISTANT CHIEF OF DAIRY DIVISION.

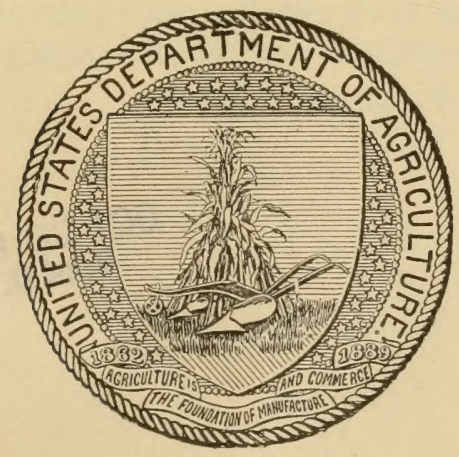

WASHINGTON:

GOVERNMENT PRINTING OFFICE. 


\section{LETTER OF TRANSMITTAL.}

United States Department of Agriculture, Bureau of Animal Industry,

Washington, D. C., May 15, 1903.

SIR: I have the honor to transmit herewith a manuscript dealing with all phases of the milk supply of two hundred cities and towns in the United Statés, and recommend that it be published as Bulletin No. 46 of the series of this Bureau.

Respectfully,

Hon. JaMes WILsON,

D. E. Salion,

Chief of Bureau.

Secretary of Agriculture.

Dy. -48 .

2

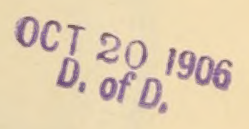




\section{PREFATORY STATEMENT.}

This report upon "The milk supply of 200 cities and towns" is very largely the work of Mr. R. A. Pearson, the Assistant Chief of the Dairy Division prior to September last.

If the full statistics of the market milk industry could be given, the importance of this form of dairying would be better appreciated. It is not known how many persons are actually engaged in the production, transportation, and sale of milk for market. Based upon the Twelfth Census of the United States, about 1,000,000,000 gallons of milk are sold annually by the owners of the producing cows, for consumption in the natural state or for household purposes. The value of this product, joined with the capital invested in production, transportation, distribution, and delivery, constitutes an interest of great magnitude.

The business is also one of interest and importance to a vast army of consumers. It is not surprising, therefore, to find so much attention being given to the improvement of this branch of dairying. A knowledge of what has already been accomplished and what is now being done to promote this good work should contribute to further progress. It is with that view that the facts included in the accompanying report have been collected and compiled.

Henry E. Alvord, Chief of Dairy Division. 



\section{CONTENTS.}

Pisce.

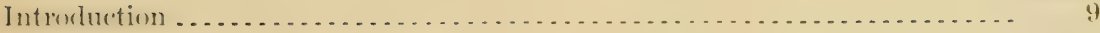

Statisties and general information . . . . . . . . . . . . . . . . . . . .

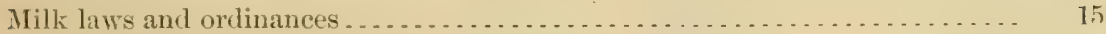

Supervision of the production and handling of market milk ...........

Suggestions for the improvement of market milk ................. 24

Tables showing the statisties of milk supply and supervision. . . . . . . . . . .

Short statements regarding the milk supply of cities and towns ...........

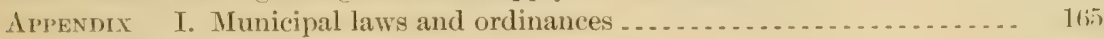

II. I milk dealer's rules . . . . . . . . . . . . . . . . . . . . . . 1 .

III. Jilk commission rules .......................... 1s?

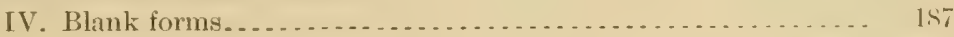




\section{CATALOGUE OF CITIES.}

[Including all of the 161 cities in the United States having a population over 25,000 each, also 39 selected cities and towns of smaller size.]

Stutes and cities, population, and page reference to discussion of dairy data.

[Populations are according to the Twelfth Census.]

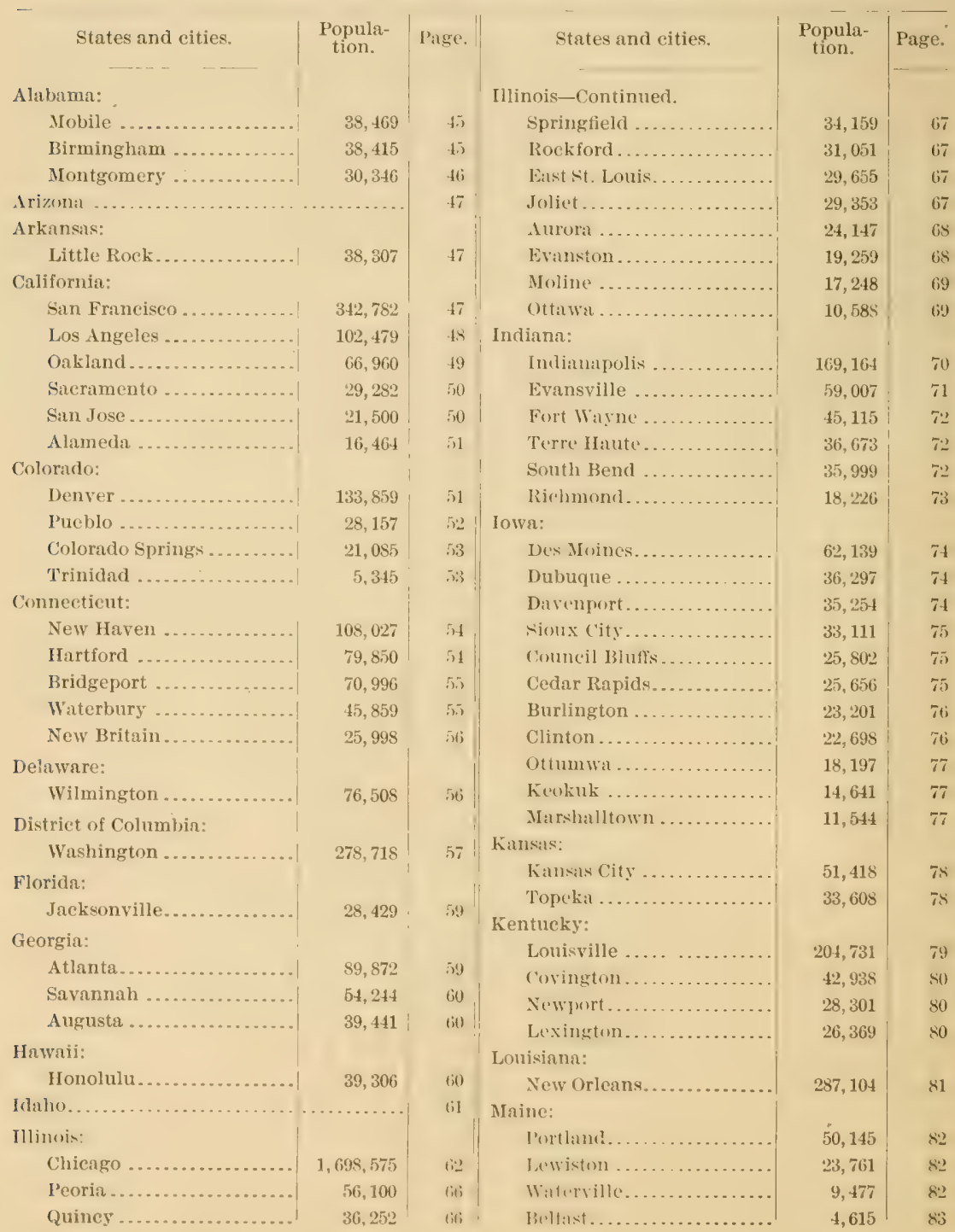




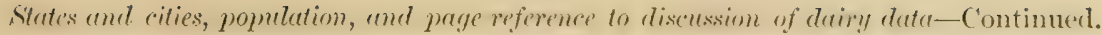

\begin{tabular}{|c|c|c|c|c|c|}
\hline States and cities. & $\begin{array}{l}\text { Popula- } \\
\text { tion. }\end{array}$ & Page. & States and cities. & $\begin{array}{l}\text { Popula- } \\
\text { tion. }\end{array}$ & Page, \\
\hline Maryland: & & & New Jersey: & & \\
\hline Baltimore & 508,957 & 81 & Newark ..... & 246,070 & 112 \\
\hline Massachusetts: & & & Jersey City .. & 206,433 & 114 \\
\hline Boston ..... & 560,892 & 86 & Paterson....... & 103,171 & 114 \\
\hline Woreester.. & 118,421 & 87 & Camden ....... & 75,935 & 115 \\
\hline Fall River... & 104,863 & 88 & Trenton ...... & 73,307 & 115 \\
\hline Lowell ....... & 94,659 & 89 & Hoboken ..... & 59,361 & 116 \\
\hline Cambridge. & 91,886 & 90 & Elizabeth.... & 52,130 & 116 \\
\hline Lynn..... & 68,513 & 90 & Bayonne..... & 32,772 & 116 \\
\hline Lawrence.... & 62,559 & 91 & Atlantic City .. & 27,838 & 117 \\
\hline New Bedford. & 62,442 & 91 & Passaic ......... & 27,777 & 117 \\
\hline Springfi & 62,059 & 92 & New Brunswick & 20,006 & 117 \\
\hline Somerville. & 61,643 & 92 & Montelair...... & 13,962 & 117 \\
\hline Ifolyoke... & 45,712 & 93 & New Mexico..... & 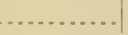 & 123 \\
\hline Brockton. & 40,063 & 93 & New York: & & \\
\hline Haverhill & 37,175 & 91 & New York ... & $3,437,202$ & 124 \\
\hline Salem .... & 35,956 & 94 & Buffalo ...... & 352,387 & 127 \\
\hline Chelseil... & 34,072 & 94 & Rochester... & 162,608 & 128 \\
\hline Malden... & $33,66 t$ & 95 & Syracuse..... & 108,374 & 129 \\
\hline Newton .... & 33,587 & 95 & Albany ........ & 94,151 & 130 \\
\hline Fitchburg ... & 31,531 & 96 & Troy (and Lansingburg) & 73,216 & 131 \\
\hline Taun & 31,036 & 96 & Utica ......................... & 56,383 & 131 \\
\hline (iloucester.... & 26,121 & 96 & Yonkers ...... & 47,931 & 132 \\
\hline North & 24,200 & 97 & Binghamton... & 39,617 & 132 \\
\hline Woburn .... & 11,254 & 97 & Elmira ........ & 35,672 & 133 \\
\hline Melrose....... & 12,962 & 97 & Schenectady... & 31,682 & 133 \\
\hline Wake & 9,290 & 98 & & 30,315 & 133 \\
\hline North Attlebor & 7,253 & 98 & Watertown .... & 21,696 & 134 \\
\hline Michigan: & & & Mount Vernon & 21,228 & 131 \\
\hline Detroit ... & 285,704 & 100 & Lockport ...... & 16,581 & 135 \\
\hline Grand Rapids & 87,565 & 101 & Rome......... & 15,313 & 135 \\
\hline silginaw..... & 42,345 & 101 & North Carolina ... & ........ & 136 \\
\hline B:ly City.... & 27,628 & 101 & North Dakota.... & . $\ldots \ldots \ldots$. & 136 \\
\hline Jarkson . & 25,180 & 102 & Ohio: & & \\
\hline Buttlecreck.. & 18,563 & 102 & Cleveland... & 381,768 & 137 \\
\hline Lansing ..... & 16,485 & 103 & Cincinnati.... & 325,902 & 137 \\
\hline Minnesota: & & & Toledo......... & 131,822 & 138 \\
\hline Mimneapulis. & 202,718 & 103 & Columbus ... & 125,560 & 139 \\
\hline St. Paul ...... & 163,065 & 104 & Dayton ........ & 85,333 & 139 \\
\hline Duluth .... & 52,969 & 105 & Youngstown... & 44,885 & 140 \\
\hline Mississippi..... & (......... & 106 & Akron ......... & 42,728 & 140 \\
\hline Missouri: & & & Springfield .... & 38,253 & 140 \\
\hline st. Louis & 575,238 & 106 & Canton ....... & 30,667 & 140 \\
\hline Kansas ('ity" & 215,170 & 107 & Hamilton.... & 23,914 & 141 \\
\hline St. Joseph .. & 102,979 & 108 & Warren ....... & 8,529 & 141 \\
\hline Joplin ....... & 26,023 & 108 & Fostoria ...... & 7,730 & 142 \\
\hline Mor:tana: & & & Oklahoma....... & $\ldots \ldots \ldots$ & 142 \\
\hline Butte......... & 30,470 & 109 & Oregon: & & \\
\hline Nebraska: & & & Portland .... & $90,426\}$ & 143 \\
\hline Omaha... & 102,555 & 109 & P'ennsylvania: & & \\
\hline Lincoln ........ & 40,169 & 110 & Phulallelphia .. & $1,293,697$ & 141 \\
\hline South Omahit... & 26,001 & 110 & Plttsburg .................... & 321,616 & 145 \\
\hline Nevarla ...................... & & 111 & Allegheny................ & 129,896 & 146 \\
\hline New Hampshire: & & & Seranton ................ & 102,026 & 146 \\
\hline Manchester.. & 56,987 & 111 & Reading ................ & 78,961 & 147 \\
\hline
\end{tabular}

ancluding Kansas City, Kans. 
States and cilies, population, and putge reference to discussion of dairy datu-Continued.

\begin{tabular}{|c|c|c|c|c|c|}
\hline States and cities. & $\begin{array}{l}\text { Popula- } \\
\text { tion. }\end{array}$ & Page. & States and cities. & $\begin{array}{l}\text { Popula- } \\
\text { tion. }\end{array}$ & P'age. \\
\hline Pennsylvania-Continued. & & & Texas: & & \\
\hline Erie ................. & 52,733 & 147 & San Antonin. & 53,321 & 156 \\
\hline Wilkesbarre... & 51,721 & 148 & Houston .... . & 44,633 & 157 \\
\hline Harrisburg ... & 50,167 & 148 & Dallas ...... & 42,638 & $15 \%$ \\
\hline Lancaster.... & 41,459 & 148 & Galveston ... & 37,789 & 157 \\
\hline Altoona ....... & 38,973 & 149 & Fort Worth..... & 26,688 & 158 \\
\hline Johnstown ... & 35,936 & 150 & Utah: & & \\
\hline Allentown.... & 35,416 & 150 & Salt Lake City. & 53,5331 & 158 \\
\hline Mekeesport.. & 34,227 & 150 & Vermont .......... & & 158 \\
\hline Chester....... & 33,958 & 150 & Virginia: & & \\
\hline York .......... & 33,708 & 150 & Richmont. & 85,050 & 159 \\
\hline Williamsport. & 28,757 & 151 & Noriolk... & 80,000 & 109 \\
\hline New eastle... & 28,339 & 151 & Norion... & 40,624 & 159 \\
\hline Easton..... . & 25,238 & 151 & Washington: & & \\
\hline Lebanon...... & 17,628 & 151 & Seattle ... & 80,671 & 160 \\
\hline Meadville.... & 10,291 & 152 & Tacoma .. & 37,714 & 160 \\
\hline Phœenixville... & 9,196 & 152 & Spokane.. & 36,848 & 160 \\
\hline Rhode Island: & & & West Virginia: & & \\
\hline Providence... & 175,597 & 153 & Wheeling & 38,878 & 161 \\
\hline Pawtucket ....... & 39,231 & 154 & Wisconsin: & & \\
\hline Woonsocket... & 28,204 & 154 & Milwaukee. & 285,315 & 162 \\
\hline South Carolina: & & & Superior... & 31,091 & 163 \\
\hline Charleston ... & 55,807 & 154 & Racine .... & 29,102 & $16: 3$ \\
\hline South Dakota ... & ........ & 155 & Lat Crosse.. & 28,895 & 163 \\
\hline Tennessee: & & & Oshkosh... & 28,281 & 164 \\
\hline Memphis.... & $10^{2}, 320$ & 155 & Greenbay.... & 18,681 & 164 \\
\hline Nashville................. & 80,865 & 156 & Marinette ... & 16,195 & 164 \\
\hline Knoxville............... & 32,637 & 156 & Waukesha.... & 7,419 & 165 \\
\hline Chattanooga ............ & $30,15 \downarrow$ & 156 & Wyoming ....... & $\ldots \ldots \ldots$ & 165 \\
\hline
\end{tabular}




\section{TIIE MILK STPPLY OF TWO HUXDRED CITIES AND TOWNS.}

\section{INTRODUCTION.}

No branch of the dairy industry has receired more attention in recent years or made more substantial progress than that of producing milk for delivery to consumers or shipment to market. Nearly onethird of all the milch cows in the United states are necessiry to supply the people with milk for use in its natural state.

The demand for improrement in the milk supply and milk service bas led to much better practices on the part of many of those connected with different phitses of the husiness. P'roducers give more are to the selection and breeding of eows, their health and housing. food and water; to the matter of cleanliness in milking and the calle of milk while on the farm. There have been marked improvements in ressels and methods of shipping, means and manner of transportation, storage, distribution, and delivery. The small glasis jar, or hottle, as a complete and sealed ressel, to pass unopened from producer to consumer, if desired, is a great advance in expuity, purity. and security of delivery. It has heen rapidly improved from the clumsy form in which it was introduced twenty-five years ago, and hats ahost reached perfection as al glass ressel for this purpose. It is yet too heary, short lived, and expensire, howerer. The ideal parckige for milk ("arriage and delivery, light, clean. safe, and so (heap) ats to be used only once and then destroyed, has yet to be found.

Municipal governments, as well as voluntary civie organization and private enterprise, are giving more and more attention to this important subject of the milk supply, its proper regulation, supervision, management, and improvement.

Much reformatory work is still needed in the improrement of all those parts of the business which are within the control of the producing farmers. This requires the uniter efforts of all public and private agencies which can he interested in it and brought into action.

More important is the sistem. or present lack of system, in distribution and delivery. Producers and consumer's are jointly carrying an untold burden in supporting armies of men and "means of transportation" engaged in duplication, or rather multiplication, of labor, 
where intelligent cooperation would be a distinet benefit to all concerned. Here and there some encouraging work has been done, but the problem needs to be earnestly studied. A great opportunity awaits the successful practical reformer in this important field.

It is desirable to know what bas already been done and what measures have been found efficacious, in order to guide new movements or revise old ones in the same direction. To this end the compilation of facts has been made which will be found in the following pages. The report shows the legal requirements as to market milk in every State and Territory having laws upon the subject, and includes a more or less detailed account of the milk supply of all the 161 cities in the United States having a population over 25,000 each; also of 39 selected cities and towns of smaller size, the smallest being Belfast, Me., with a population of 4,615 . The information given is nearly all based upon official documents and special reports from officers who are charged with the enforeement of so-called milk laws and ordinances.

Present conditions are well set forth in the material collected. In numerous instances recommendations for improvement are included, as given by health officers and milk inspectors. This does not imply that they are indorsed, although many of them are worthy of indorsement. This Department has recently published an article under the title, "Narket milk: A plan for its improvement," which was prepared after a careful study of much of the material used in the present report. It sets forth a plan which, it is believed, could be followed in any town or eity where there is a live interest in the subject. That plan applies chiefly to the further improvement of the better "lass of dairies and would have little direct influence on the poorest. It should therefore be supplemented by certain legal requirements and their thorough enforcement. The report now presented will be especially useful in places where some regulation of the milk supply is first contemplated or: where better regulations are needed. The correspondence of the Dairy Division shows there are many such, including cities and towns having no legal prorisions whatever in reference to milk. Inquiries have come in large number for suggestions as to the best way to supervise market milk, and especially as to methods generally employed.

It is hoped that this summary statement of conditions now prevailing throughout the country in reference to market milk will encourage action toward the improvement of that important food supply and lead to a larger use of it. So much has been said and written regarding impure market milk that many persons have become unnecessarily alarmed. For this reason any fair inquiry into this subject which brings out facts and suggests steps that should be taken for the benefit of the industry should be welcomed by milk inspectors and consumers as well as milk producers and dealer's.

" Seventeenth Anmual Report, Bureau of Animal Industry (1900), Wr. 158-193. 


\section{STATISTICS AND GENERAL INFORMATION.}

The usual methods by which milk is distributed in cities, towns, and villages are known to every observing person, and those by which it is produced are known to most people; but statistical facts regarding the use of milk are not generally known, although they are exceedingly interesting and suggestive. All of the statistics ohtained relating to the market milk of the two hundred municipalities have been arranged in tables (pp. 26-44), in which data for any city or town can be readily seen and compared with others. Only a few of these statisties will be repeated here. Figures showing the total amount of milk used in large cities are very impressive, but they do not give the extent of the use of milk as well as those representing its per capita consumption or supply. The following statement shows the maximum, minimum, and arerage number of pints of milk apparently consumed daily in each of the four classes into which the cities and towns have been arranged:

Daily per capita supply of mill.

\begin{tabular}{|c|c|c|c|c|}
\hline & Class I. & Class II. & Class III. & Class IV. \\
\hline Number of eities reporting ........................... & 38 & 39 & 63 & $\cdots$ \\
\hline 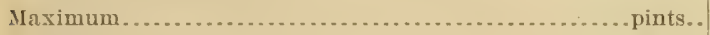 & 1.17 & 2.00 & 1.42 & 1.18 \\
\hline 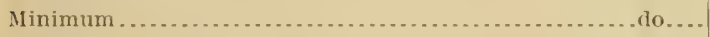 & .27 & .10 & .12 & .23 \\
\hline 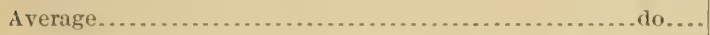 & .61 & .63 & .58 & .57 \\
\hline
\end{tabular}

It is believed that these figures are reasonably areurate. They are based upon the population aceording to the last census and estimates of milk used daily furnished by local officials best qualified to judge. In not a fow cases careful records are kept by milk inspectors of the milk sold by each person having a license, but generally it has been necessary to depend upon estimates. Whenever the estimates appeared to be unreasonably large or small, they were returned for revision.

The arerage quantity of milk per (apita provided in the daily supply and presumably consumed in the largest cities (Class I) is found to be 0.61, or practically two-thirds, of a pint; in cities of Class II (including all those with a population between 50,000 and 100,000), the average consumption is 0.63 pint; in (lass III (cities having a population between 25,000 and 50,000$)$ it is slightly less, or 0.58 pint; and the average of 39 cities and towns, with a population less than 25,000 , is 0.57 pint. In Boston, Worcester, Newton, and Fitchburg, Mass.; Elizabeth and Hobolen, N. .J.; Providence, R. I.; Minneapolis, Minn.; Pueblo, Colo.; Elmira and Mount Vernon, N. Y.; and Sioux City, Iowa, the arerage daily per capita consumption of milk is reported as 1 pint or more. By referring to the separate statements for these cities it will he seen that some explanation is usually given for this 
seemingly large use of milk. The smallest arerage eomsumption of milk in the larger cities is 0.27 , or practically one-fourth, of a pint per capita; this is in New Orleans, where the supply is notably inardequate and unsatisfactory. The average per capita consumption of milk in four of the largest Southern cities is only 0.38 pint, which is less than one-half of the average supply in large Northern citics.

Satisfactory statistics concerning skimmed milk were olntained from only a few of the larger cities reporting. In Indianapolis, Ind., and St. Joseph. Mo., the largest amounts were given, the supply being about one-third of a pint per capita, in addition to the whole milk used. Several eities reported a little lesis than 0.1 pint, and several other's as little as 0.01 pint per capita. Boston, Mass.; Jersey (uty and Elizabeth, N. J.; New York, N. Y.; Nt. Louis, Mo.; and Bridgeport, Conn., report that no skimmed milk is used.

The quantity of (ream per capita in the larger cities raried in sup)ply from 0.01 pint daily to 0.19 pint.

The number of stores and wagons engaged in the sale and distribution of milk shows that the methods of handling it differ considerably in different places. Milk is sold from 12,000) stores in New York City, or an average of 1 store to every 286 persons, and it is delivered from $t, 000$ wagons, or an arerage of 1 wagon to every 859 persons. In all the cities of Class 1 , there is an arerage of 1 stope to 1,17 fi persons, and in (lasis II, to 2,14 ) persons, showing that in the smaller cities wagons are mainly depended upon. In cities of the first two classes, including all with a population above 501,0100 , there is an arerage of 1 wagon to about ist persons. A factor to be ronsidered in this eomnection is the number of eows within the city limits. Some cities report sereral thousand cows in herds within their boundaries, and most cities have quite a number of rows kept singly for the private use of the families owning them.

'The tables show a wide rariation in the prices paid for' milk in different parts of the country. Producers usually recenve, on their farms, from 2 to 3 cento per quart in the summer and 8 cents or more in winter, but these limitware of ten exceeded. On the other hand. in some eases and in some seasons, producers receive less than erents a puart. It was attempted to ascertain the exact prices received by producers on their farms, but in some cases the question seems to have heen misunderstood, and the price reported was apparently that paid for the milk delivered in the city. Allowance should he made for this posible error, especially whenerer the priee seems to be too high. The arerage price paid by consumers of milk when retailed in small quantities is about 6 cents in summer and 7 cents in winter.

In numerous instances an advance of 1 or ey cents per quart for milk from "model dairies" is reported. But the milk from many soalled model dairies is sold at the same price as other milk, and in 
most of these cases the term probably refer's to dairies that are conducted in a mamner only slightly better than the ordinary. The term "model diriry" is differently understood by different persons, hence the number of these dairies reported to be near cities and towns can not be fairly compared. Usually only one, two, or three are reported for a city and often none.

A truly "model dairy" is one which is conducted in the best practicable mamner known to seience. They are not necessarily places where money has been larishly expended for fine blooded cattle and highly adorned buildings; such places, if they are not properly conducted, are far from "model." But they are dairies where milk is produced and handled that is as clean and wholesome as milk "an he made; the cows are in good condition, free from disease in any stage, and frequently examined by a skilled reterinarian, who removes from the herd any suspicious animals; none but wholesome feeds are used; the stable is abundintly lighted and well ventilated, often thoroughly cleaned and kept in a correct sanitary condition; the cows are liept clean and romfortable; the attendants are healthy and cleanly; all utensils are sterilized daily; great care is taken to protect the milk from contamination; the milk is promptly cooled, and it should contain less than one one-thousandth part as many biteteria as are found in much of the milk regularly sold in cities and towns.

A model dairy does not require a large ontlay of apital, but it repuires a keen intelligence and unremitting care in its management. Some increase in rumning expense is necesisary, as would be expected. Such daries are few, hut their number is slowly increasing. One of the chief reasoms why they do not increase more rapidly is that the public does not appreciate the advantages of their product and seems unwilling to pay a slightly advaneed price for it. If the question were generally understood, there would be such a demand for highgrade milk at fair prices that model dairies would quickly come to be the rule instead of the exception. When consumer's are willing to pay enough to encourage dairymen to exercise close supervision over their cows and to take all of the precaution necessary to insure milk of high quality and purity, from both ehemical and bacteriological standpoints, and will insist on having such milk, then that kind will be amply supplied. It is the duty of dairymen themselves to help bring about this condition. Milk is cheaper than most other foods (even when it is sold at an advanced price made necessary by extra care in its production), and for this reason, as well as others, it is well suited to form a large part of the dietary.

The territory from which milk is supplied to cities and towns might he dirided into three zones. The first includes the city itself, which often, as has been stated, has large numbers of cows within its limits; the number is sometimes in the thousands. The second zone includes 
the distriet surrounding the eity, from which milk is carried by wagons. These wagons usually arrive in the city in time to serve milk early in the morning; they may deliver the milk of the previous day or the milk of the same morning and the previous erening. The third zone includes a much greater territory, from which milk is carried to the cities by railroads, trolley lines, and steamboats. In about a dozen cities more than three-fourths of the supply comes from this zone. Seren cities-New York, Philadelphia, Newark and Jersey City, N. J., Baltimore, Md., Memphis, Tenn., and Lynn, Mass.-report milk received from points distant 200 miles or more. The average of the longest distances from which milk is supplied to cities of Class I is practically 100 miles, while the average of the longest distance from which it is supplied to cities of Class II is practically 50 miles. The milk trains bringing milk from medium distances to the cities usually arrive between $s$ and 11 o'clock in the morning with milk of the same morning and previous evening. Much of this is held over in refrigerator tanks of the dealers to be served the following morning, when a part of it is twenty-four hour's old and the remainder thirty-six hour's. Trains carrying milk the longest distance usually arrive in the night, so that their milk can be served the following morning and is not any older than much of that coming from nearer points.

The portion of milk delivered in glass bottles was stated for only about half of the cities reporting. In some cases almost all of the supply is handled in this way. It appear's from the reports that the average retail price is no higher in cities where a large portion is served in bottles than in eities where bottles are but little used. The delivery of milk and cream in bottles is increasing in faror. 'This should he so, for the system has many advantages. Each bottle is a sufficiently exact measure, holding a quart, pint, or half pint, and unless it has been very carelessly filled, contains its right proportion of cream. Bottles are closed packages and thoroughly protect their contents from dust and foul air. They may be easily sealed and their contents guaranteed. The bottles are heary and fragile and expensive, but the greatest objection to their use is on account of their abuse. They are sometimes refilled without having been properly cleansed. This is a dangerous practice, as milk might be put into jars that had been in some way infected with the germs of a contagious disease, and thus carry the disease to other houses and families. Milk jars are easily sterilized, and whenever this is done there seems to be no serious oljection to counterbalance the many advantages of their use.

The pasteurization of market milk is not generally practiced. A few cities report that a small portion of the milk is thus treated. According to returns, the largest quantities of pasteurized milk are sold in Los Angeles, ('al.; Pittshurg, Pal.; St. Paul, Minn.; Kansas City, Kans.; Salt Lake City, Utah; Reading, Pa.; Troy and Bingham- 
ton, N. Y.; Council Bluffs, Iowa; and Lexington, Ky. Sereral cities report that no pasteurized milk is sold within their limits. The practice of pasteurization appears to be gradually extending. Yet the medical fraternity is divided in opinion as to its expediency, and the best sentiment favors natural milk produced and delivered in such a pure and protected condition as to be greatly superior to any pasteurized article. Too often milk is ofiered for sale with the claim that it has been pasteurized, when it has actually been more harmed than helped, the process to which it has been subjected being unworthy the name. If done at all, pasteurization should be in the hands of competent persons, having efficient apparatus.

\section{MILK LAWS AND ORDINANCES.}

In thirty-five States there are laws referring to market milk. In nine other States (and Territories) there are pure-food laws which have a bearing upon the milk supply. In twenty-six States there are ofti('ials whose special duty it is to enforce these laws. Full copies of all the laws but two or three of the latest are included in previous publications of the Dairy Division. Almost every city and many towns and villages have ordinances or board of health regulations concerning the milk supply. Alstracts showing the state requirements and also the local requirements, so far as arailable for the 200 cities and towns here reported upon, will be found in the following pages. (In the abstracts. effort is made to state only the most important features, often omitting the repetition of details of enforcement, the usual authority for inspectors to perform their work, methods of taking samples. rete.) In addition to the special milk laws, general pure-food and sanitary hass and regulations are sometimes construed to apply to milk.

Too often milk laws and ordinances are faulty because their requirements are not dearly expressed. The form of expression is sometimes so cumbrous that the meaning is unintelligible to the average reacler, or the requirements may be rague or obviously inexact, or they may be expressed in very general terms, thus rendering execution practically impossible. For example, some laws probibit the use of any cow feed that is fermented. A strict interpretation of this would exclude silage, a most excellent dairy feed. This could hardly have been intended; but, if one feed is excepted, the exemption of other fermented feeds could be demanded. A law may require dairy stables to be well lighted. What does this mean? A stable considered by some persons to be well lighted would be very poorly lighted from the standpoint of others. A better way of expressing this requirement would be to name a minimum number of square feet of unobstructed windows for a given cubic space within,

On the other hand, some laws and ordinances go to the opposite 
extreme. They seem to show an effort to include the reguilation of almost every detail of dairy work. It is generally considered impuratieable to enforce such laws, and gradually their requirements are more and more ignored until attention is given to none of them or to only a few that ean be most easily enforced.

It is an open question whether state laws or local regulations may be the more effieient in improving the milk supply. It is the general practice to leave to local anthorities all control after the milk is within the eity limits, but in a few cases states exereise authority within the cities and towns as well as elsewhere. It is prohably true that the milk supply of the smaller towns receives hetter ofticial attention when its control is in the hands of the State. State inspector's visit the small towns oceasionally, at least when it is shown that their presence is needed, and this is much better than no inspection, which is the rule in many towns like the one from whose health officer the following letter was received:

It is humiliating to be compelled to confess that a city which is well advanced in all other matters of sanitation should be without ordinances regarding the milk supply. On two different oceasions before the city council assembly I moved that such ordinances be enacterl, and both times the matter was shelved for the alleged reason that it might offend the susceptibilities of some milk venders.

The argument that the State should control the milk supply, hraume local regulations have no fore beyond the city limits, has been shown by numerous eities to have little weight. In places which are not sufticiently protected hy the laws of the states in which they are situated or the laws of other States from which milk is recenved, the matter is thus managed: It is provided hy local ordinames that no milk shall enter the corporate limits unless it comes from a dairy holding a permit, or license. from the city authoritien. The rity am make its own conditions for issung permits. These are usually given only to dairies actually inspected or whieh fumish satisfactory eridence of heing in approyed condition. The permits maty be canceded for cause. A thorough system of milk and dairy inspection on this basis affords ample protection to milk consumers, as the soares of the milk supply can be held completely under local control.

City ordinances relating to milk supply are similar to state laws, hut generally more detailed and more clearly stated. 'They are often supplemented by regulations and rules of the local hoards of health. The character of the eity requirements, as well as those established by State authority, ean best he ascertaned by examining the abstrats of the laws, ordinances, otc., which are given elsewhere in separate statements for cities and towns. I few milk ordinances are printed in full in Appendix I (p. 165); also a number of sections talien from other ordinances which are of interest, because they show commendable ways for preseribing different requirements. 
The suljects of most frequent legislation in connection with the supervision of market milk are shown by the statement below. The milk ordinances and regulations of 126 cities were examined with especial care, and the number of those having similar requirements are given. The most popular subjects for legislation are thus readily seen:

Subjects of most frequent legislation in connection with market milk.

\begin{tabular}{|c|c|c|c|}
\hline Subjects. & $\begin{array}{l}\text { Number } \\
\text { of cities. }\end{array}$ & Subjects. & $\begin{array}{l}\text { Number } \\
\text { of eities. }\end{array}$ \\
\hline Dairies: & & Care of milk: & \\
\hline License or permit required.......... & 12 & Milk vessels to be nonabsorbent .... & 5 \\
\hline - Special authority for inspections.... & 68 & Milk vessels to be thoroughly & \\
\hline l'ure water supply ............... . & 8 & cleaned......................... & 32 \\
\hline Drainage of barnyards ....... & 12 & Milk to be promptly removed from & \\
\hline Stables: & & the stable................................. & 11 \\
\hline Proximity to other buildings ....... & 6 & Straining.................. & 9 \\
\hline Light........................ & 15 & Cooling and aerating.......... & 15 \\
\hline Ventilation...... & 32 & Conditions of storage.......... & 23 \\
\hline Floor space............ & 15 & Sale of milk: & \\
\hline Air space ........ & 10 & Licenses, or permits .................. & 92 \\
\hline Cleanliness............ & 47 & Licenses to be publicly displayed ... & 24 \\
\hline Removal of manure................ & 25 & Source of supply to be posted ...... . & 14 \\
\hline Drainage....$\ldots \ldots \ldots \ldots \ldots$ & 17 & General inspection in eities.. & 75 \\
\hline Other than dairy animals to be ex- & & Signs on wagons ............. & 79 \\
\hline cluded........................... & 1 & Unsanitary milk prohibited.. & 109 \\
\hline Sanitary milk room ............ & 11 & Confiscation of impure milk ........ & 30 \\
\hline Employees: & & Definite standard for composition... & 67 \\
\hline Personal eleanliness ...... & 20 & Skimmed milk prohibited........... & 12 \\
\hline Contagious disease (to be reported). & 15 & Skimmed milk permitted condition- & \\
\hline If exposed to contagious disease .... & 25 & ally ..................................... & 61 \\
\hline Cows: & & Bottling at farm...................... & 8 \\
\hline Provisions for examination . & 58 & Storage of milk for sale ............. & 23 \\
\hline Diseased cows ........... & 24 & Milk tickets to be used but once.... & 16 \\
\hline Unwholesome food forbidden.. & 77 & Milk wagons to be covered........... & 12 \\
\hline P'ure water supply . .......... & 40 & Milk wagons not to carry garbage .. & 5 \\
\hline Cleaning cows....... & 27 & Sellers to register customers......... & 7 \\
\hline Milk rejected at calving time.. & 33 & & \\
\hline
\end{tabular}

In most places having ordinances the sale of unsanitury milk is prohibited, but not infrequently in such general terms that the prohibition is practically without force.

The usual standard requred for milk is 12 per cent total solids, including 3 per cent of fat. In a few eases higher standards are in force during all the year except the summer months. In some ordinunces the standard is expressed in this peculiar manner" "Milk shall contain at least 12 per cent of milk solids, of which 3 per cent shall be fat." This literally means that the milk must contain three onehundredths of twelve one-hundredths, or much less than 1 per cent of fat:

So much trouble has been experienced in some citice in regulating the sale of skimmed milk that in a few cases the sale of this cheap $25839-$ No. $46-03--2$ 
and excellent fool is prohibited. The difficulty arises from the fact that dealers are allowed to carry skimmed milk in the same vehicles with whole milk or keep it in the same refrigerators or ehests. It is then a simple matter to substitute the one for the other in selling to customer's who are incapable of detecting the difference or unable to get redress. Some cities require all skimmed milk to be sold from cans that are painted blue or another distinguishing color. In one place the vender must give to the consumer a printed slip on which it is stated in large type that the milk is skimmed. In one or two other places skimmed milk must be peddled in rehicles different from those used for whole milk. Such methods have been proved so simple and effective that they should be adopted in cities where skimmed milk is now excluded. A good supply of this article, sold honestly on its merits, is of so much benefit to consumer's, and especially to the poorer classes, that prohibition of its sale is inexcusable.

Many different penalties are provided for the violation of milk laws. They are usually fines and imprisonment, but in a few tomns it is recuired that the names of violators be published, thus notifying the public who have been convicted of selling poor milk.

In many eases milk dealers have arlopted the commendable practice of issuing rules and instructions to the producers supplying them with milk. I copy of a set of these rules is shown in Appendix II (p. 1s1). Such rules are a most valuable supplement to the ordinances. The "Fifty dariry rules" issued by this Department, in suitable form for posting in stables and milk rooms, have been widely distributed to dairymen through milk dealer's and milk inspection officials, and by being published in various places.

An excellent list of the conditions which should be found at a wellconducted dairy is given in Appendix III (p. 1.2.). These requirements form the chief part of the contract between the Essex County (I. I.) milk commission and the dairyman whose milk receives the indorsement of this commission.

No attempt is now made to offer what might be called an ideal milk law. Such would be suggestive in the many eities and towns where new legislation is heing considered, hut it is believed that suggestions as useful can be had hy a study of the laws which are al ready in force. An ordinaner suitable in one city or town might be quite inapplieable in another. For example, the larger cities, where dealer's purchatse their milk in such a way as to know practieally nothing of its somre, should have laws different in many respects from those in force in places where all the milk sold is produced by the persons who sell it. The regulations should he as clear and brief as possible, and those relating to milk should be enacted together, so they can be printed separately for distribution. In many eases the distribution of ordi- 
nances is rendered almost uscless because they are long and cumbersome, or beanuse the milk regulations are mingled with those on other subjects. In one city requirements regarding the milk supply alternate with those regarding the burial of the dead.

It is a serious mistake not to comsult with reputable dairymen and dealers when laws concerning them are being considered. Such persons welcome the enactment and rational enforcement of proper measures to regulate the production and sale of milk. The prohibition of adulteration and unsanitary methods helps their business by driving out competitors whose false claims of excellence succeed in holding the trade of many customers.

\section{SUPERVISION OF THE PRODUCTION AND HANDLING OF MARKET MILK.}

With rery few exceptions, there is some supervision of the milk supply in all cities in the Lnited States having a population orel 50.000 . Much less supervision is exereised in cities with a population between 50,000 and 2.5.1000, and in smaller cities and towns supervision is the exception rather than the rule. It is easily seen that in small places, where persons are known or may soon become more or less known throughout the entire community, the same need for official attention to the milk supply does not exist as in more populous centers. Yet this is not sufficient reason for ignoring the subject altogether, as is too often done.

There is the widest variation in the methods followed in different places and the character of the work performed. As stated, in many cities and towns this matter receires no attention, or almost none, and. in some of these, adulterations and general neglect of sanitary measures may be found on every hand, if the replies to inquiries from this office may be relied upon. But it should be added that in some places, where there is little or no supervision. the quality of the milk is excellent.

As has heen explained, most of the states have more or less definite laws relating to the milk supply of rities and towns. In very few of them, however, is there any real effort at supervision by State officials. In Iowa and New York and one or two other States regular corps of milk inspectors are kept in the field. Some are located permanently in the larger cities and others make occasional unannounced visits to smaller places. In general these officials plan their own routes, and respond promptly to calls from places where their presence is particularly desirable. Their duties are largely the examination of milk samples for adulteration. The lactometer is relied upon mainly to indicate suspicious samples, and these are later subjected to more accurate tests. The effect of a risit of the State milk inspector to one 
town, where he is apparently too seldom seen, is shown ly this statement from the health officer:

The only protection the citizens have hat from impure milk is an oceasional visit from a State milk inspector, who invariably caught an offender and emptied his can in the gutter; and some of the other dealers hearing of it, hurrierl back to their homes and left their customers unsupplied.

Some inspections of the sanitary conditions of dairies and milk stores are made hy State authorities, but these are not customary except for special cause, such as an outbreak of disease or evidence of unusual conditions refuiring attention. The New Jersey hoard of health has prepared blanks on which reports of inspections are made and which show how thorough it is proposed they shall be in that State. (See Appendix IV. p. 187.)

Alhough in some cities and many towns there is no local supervision of the milk supply, except an oceasional action of the hoard of health or police in connection with a particularly flagrant case, yet, on the whole, there is much more work done along this line by local officials than hy State officials; the former, however, often act under State laws.

Milk ordinances and regulations being considered health measures, their cnforement is generally intrusted to the board of health. When it is proposed to accomplish something along this line, special officers are appointed to take charge of the work. They are usually given the title of "milk inspector," hut not infrequently their titles are longer and indicate additional duties, such as "inspector of milk and vinegar," "inspector of milk, provisions, kerosene oil, and rinegar," ete.

Ofticials in most of the cities having a population over 1010 , (100) (('lass I) reported fully mpon the work performed in the supervision of their milk supply, and officials in a large portion of the rities with population between 50,000 and 100,000 (Class II) did likewise. Inotails could be furnished from only a small portion of the cities hetween 25,000 and $50.000($ population (C)ass III), and of those of less than 25,000 population (Class IV). From these reports intresting data were obtained, which are tabulated as follows:

Alstract of interesting items from cities of the different classes.

Items and grouping of same.

Amount annually expended in supervision of the milk supply: Cities reporting

Largest amount reported.

Smallest amount reported.

Average amount reported

Milk simples tested for composition

Cities reporting

Largest number reported

Smallest number reported

Average number reported.
Class I. Class II. Class III. Class IV.

\begin{tabular}{r|r|r|r} 
& & & \\
\hline 29 & 33 & 40 & 31 \\
$\$ 13,000$ & $\$ 2,500$ & $\$ 2,500$ & $\$ 1,200$ \\
$\$ 1,000$ & 0 & 0 & 0 \\
$\$ 2,953$ & $\$ 685$ & $\$ 421$ & $\$ 282$ \\
& & & \\
37 & 32 & 52 & 38 \\
79,657 & 12,000 & 5,000 & 4,000 \\
0 & 0 & 0 & 8 \\
6,834 & 1,076 & 521 & 471
\end{tabular}


Alstract of interesting items from cities of the different clusses-Continued.

Items and grouping of same.
Class I. Class II. Class III. Class IV.

Milk samples examined bacteriologically:

Cities reporting

Largest number reported.

Smallest number reported.

A verage number reported.

Dairy herds in eity limits:

Cities reporting .

Largest number reported

Largest number inspected reported.

Smallest number reported.

Smallest number inspeeted reported.

Average number reported.

Average number inspected reported

Dairy farms contributing to the supply:

Cities reporting.

Largest number reported.

Largest number inspected reported .

Smallest number reported.

Smallest number inspected reported.

Average number reported.

Average number inspected reported .

\begin{tabular}{r|r|r|r}
30 & 27 & 39 & 29 \\
390 & 125 & 43 & 275 \\
0 & 0 & 0 & 0 \\
77 & 7 & 2 & 16 \\
& & & \\
29 & 25 & 34 & 29 \\
5,500 & 100 & 200 & 83 \\
560 & 100 & 200 & 83 \\
2 & 0 & 0 & 0 \\
0 & 0 & 0 & 0 \\
297 & 21 & 21 & 12 \\
124 & 15 & 31 & 11 \\
& & & \\
17 & 18 & 37 & 30 \\
4,000 & 800 & 300 & 127 \\
300 & 228 & 250 & 127 \\
69 & 15 & 12 & 6 \\
0 & 0 & 0 & 0 \\
686 & 167 & 65 & 38 \\
114 & 64 & 37 & 29 \\
& & &
\end{tabular}

By an examination of these figures, as well as the separate reports upon different cities and towns, in another part of this publication, it is readily seen that most of the inspection work comsists of testing samples of milk to ascertain if they contain as much fat and other solids as required by the standard. 'This is very useful. but certainly not more so than inspections for other conditions that may have eren more effect upon the wholesomeness of milk than its adulteration by skimming or watering. 'The health of the cows producing milk, the health of the persons who handle it, and the conditions to which it is exposed are too often left out of consideration altogether hy consumers as well as puhlic-health ofticials. Iet there is little doubt that much more harm has resulted from the use of milk that has been contaminated through neglect of these things than from the use of adulterated milk. It is a commercial fraud to decrease the value of milk by the addition of a cheap ingredient, such as pure water, or by the removal of a valuable ingredient, such as fat (in cream), but this is insignificant compared to the evil of allowing milk to become dangerously rontaminated, as may easily result when general sanitary conditions are neglected in comnection with its production and care.

Milk laws, ordinances, regulations, etc., are usually quite well enforced, so far as the requirements regarding the composition of milk are concerned, hut heyond that the enforement is very imperfect. For example, it is commonly required that cows shall be kept in at healthful place and fed only wholesome food, ete., hut such clauses are seldom noticed. Nothing whaterer is known in most cities of the 
source of a large part of the milk sold, as many farms are never inspected. The conclitions at almost any dity in this respect are well described in the report of an inspector at IV ashington, D. C., which is abstracted on page 58 .

'The methods of work are quite similar throughout, and all details need not he given here. It is practicahle to keep a correct list of produring dairies and places where milk is sold by having them licensed. This is the first essential. It is then simply a question of finding everyone on the lists and keeping an office record of the results of the inspections. Special care must be taken in the collection and marking of samples, as these acts have to be fully described in prosecutions. The official report of the method employed in Boston is as follows:

Collections of samples for inspection are made on every week lay and frequently on Sunday. The time varies very much according to circumstances, but most of them are made in the early morning and forenoon, though often a distriet is visited in the afternom or evening. The wisual method of collecting milk samples is as follows: The collectors go to the different districts to which they have been assigned the previous day, and hegin their work very early in the morning, nsually about 2 or $30^{\prime}$ clock. Each carries a satchel in which are sample cans, bottles for return sanples, tags for identifieation of the specimens collecterl, hlank receipts, sealing wax, ete. At the time of taking a sample the collector makes a series of memoranda on a tag, which, before leaving the wagon, he affixes by means of a piece of copper wire to the handle of the sample can. The memoranda include every important point in any way connected with the taking of the milk - the name on the wagon, the license number, the name of the driver in charge, the time and exact locality, the number of cans on the wagem, the kind of can from which the sample was taken, whether the same was marked "skimmed milk," whether a sealed portion of the sample was delivered, and to whom, and any unusual or peculiar circumstances. These notes are made in the presence of the driver; and the tag, securely fastened to the sample, serves for its identification, and may later be used to refresh the memory of the collector on the witness stand in case of prosecution. In every case the person from whom the sample is taken is anked if hedesires a sealed portion of the same. If the answer is in the aftirmative, a 3 -ounce bottle is filled, properly labeled by means of a small tag, and sealed in such a way that the latter can not be removed without breaking the seal. The coliector then delivers the bottle to the person in charge, who signs a receipt for the same. As soon as the collector has obtained a sufficient number of samples he proceeds to the office, amd having delivered them to the chemist, prepares to make a second trip). If as frequently happens, he arrives at the oflice at such an early hour that nolrody else is present, he lock, his samples into a small closet, to which only himself and the chemist have keys. The second trip is made, as a rule, during the forenoon among the stores. The different districts of the city are not visited with any fixed rugularity, and thus it happens that the dealers have no idea when they may next expect a visit, and hence can not feel that having been inspered to-day there will be no risk attending the conveyanee of adulterated milk to-morrow. Collections are frefuently makle on several consecutive days in the same district by one, two, or all the esellectors, and certain districts may be thus visited twice in the same morning.

A further idar of general methods may he obtained from copies of diflerent kinds of forms used, which are shown in Appendix IV, 
(pp. 187-210). They include forms for application for license, forms on which reports of dairies are made, licenses, etc. Tseful suggestions regarding the supervision of market milk may be obtained from an examination of these forms.

The applicant for a license is commonly required to malie a simple formal request for the privilege to sell milk. This may be on a l, lank form containing only a few lines. In some cases this form has printed on its face or back a few of the requirements of the ordinaner, or the ordinance in full (seo p. 1ss). In at least one city the applicant must declare that his cows and the persons in his family and in his employ are free from certain dangerous diseases, and he must agree to give prompt notice of the oceurrence of disease (see p. 18:1). In another case the applicant must agree to numerous conditions explicitly stated (see p. 1s9). In a few cities the applicants must furnish a more or less detailed statement of the conditions ohtaining on the dairy farms or the general conduct of the business proposed (see pr 19:3). The arlvantages of requiring such astatement be fore al license is granted are readily seen. Probably then, more than at any other time, special effort will be made to answer all questions satisfactorily. If the dairy is subsequently inspected and reprorts of conditions as found are made upon blankis like the one originally filled out, they an be conreniently compared and the differences for better or worse readily noted. It should be remembered that it is as important to give attention to facilities for handling milk after it arrires in the city as hefore, and forms for this kind of inspection are in use in a few places (see p. 195). Some states and sereral cities have special forms for use in inspecting dairies from time to time, and some of them "all for many important details (see p. 196). I form upon which additions of cows to a herd must be reported is sometimes used (see p. 19!1).

Lieenses, or permits, are ustally brief, simply stating that the person or concern named is permitted to sell milk in the eity, etc., until a certuin time, unless the license is sooner reroked. In some cases separate licenses are issued for stores and wagons. It is not uncommon to print a part or all of the milk ordinance or regulations upon the license, thus keeping always in sight some at least of the requirements (see p. 173). A special form may be used for notifying negligent persons of the requirement that they must be registered, or licensed, and others to give notice that the license number must appear on wagons (see pp. 200 and 203).

The forms most commonly used in making inspections of milk in (ities and towns are those giving data regarding the collection of milk samples and upon which prosecutions may be hased (see 1). 205). Spe('ial forms are also sometimes used for giving notice that a sample of milk has been taken (́see p. 206(i); for reporting its analysis (see p. 2066); for giving notice of the eonfiscation and perhaps spilling of condemmed 
milk (see p. 2066); and for recording data when stores and wagons are inspected, ete. A special form is sometimes used to compel the discontinuance of the use of bottles at houses where contagious disease exists and giving permission to resume using them when the danger is past. Warnings of violations of the law are sometimes made on special forms (see p. 209). Many different methods of keeping office records are followed. In one city the "card system" appears to be used with success (see p. 210).

It should not be amisis here to mention the desiraloility of having as the official whose duty it is to supervise market milk one who possesses practical lnowledge of the suloject, as well as ability and integrity. Many such are engaged in this work, and their efforts are approved and encouraged alike by milk consumer's and the better class of milk producers and dealers. It is hard to overestimate their value to the community. But, unfortunately, a few persons intrusted with this important work have wrong conceptions of their duties and sometimes they do more harm than good. The official who thinks that everyone engaged in the business of producing or selling milk is intentionally a lawbreaker, or he who constantly seeks to annoy those under his jurisdiction by petty and unreasonable requirements, does a great wrong. For the best results to all concerned, the utmost care should he taken in selecting the person who will have charge of the enforcement of milk laws.

\section{SUGGESTIONS FOR THE IMPROVEIMENT OF IMARKET MILK.}

Those who reported upon the milk supply were asked to mention the chief improvements which had recently come to their attention, and to suggest methods by which further improvements might be brought athout. The improvements reported by the greatest number related to the dairies where milk is produced, and they showed that considerable adrance has been made in the character and healthfulness of the stock, the conditions under which milch cattle are kept, and the methods of handing milk. The chief improrement shown hy inspections in the cities was the decreased use of chemical preservatives in milk.

Many excellent suggestions were received regarding the improvements named and other's needed, and they will be found elsewhere in connection with the separate statements for cities and towns. I fow of the better ones are repeated below. Some exceshingly impracticabe suggestions were also recoived. Naturally, the needs which are given for some places are well met in some ot hers, yet the list includes points that might protitably be eonsidered in every eity. They are so clearly stated that comment upon them is umecessary, and are als follows: 
The registration of all dairies.

Official indorsement of properly conducted dairies.

Inspection of all herds, barns, dairy buildings. ete. once a month.

Better igating, rentilation, drainage, and cleanliness of cow stables.

Whitewashing the interior of stables.

Eradication of tuberculosis from dairy herds.

Branding of condemned cows.

Cows not to be given swill feed, ete.

Cows to be regularly cleaned.

Pasturage for city cows.

Aeration of milk in pure air.

Prompt cooling of milk and holding it at a low temperature until final delivery.

Shipment of milk from farms promptly after milking.

Delivery of milk and aream in sealed packages (glatsis bottles or small (ans) so at to aroid unneressary contamination by city dlust, ete.

Delivery of milk in cities at any hour of the day when it can be supplied in the best condition.

Restrictions upon the sale of milk in markets. andy stores, ete.

Delivery of milk from such stores in bottles only.

Mixing of herd milk to set an article of uniform composition.

Bottling of milk only at the dairy or place of general supply.

Daily sterilization of milk utensils.

More rigid inspections for preservatives in milk.

Chemical and bacteriological examinations of milk.

Standards for cream and skimmed milk.

The patsigge of no law that ean not be reatsemably well enforeed.

More pay and allowameres and greater authority for milk and dairy inspector's.

More severe penalties for violations of milk laws.

Publication of reports on inspection of dairies.

Edacation of milk producers by a liberal distribution of cireulars, leaflets, etc, bearing upon their work.

\section{TABLES SHOWING THE STATISTICS OF MILK SUPPLY AND SUPERVISION.}

For the purpose of enabling eomparison to be made between eities and towns of about the sime sizes surh datal at can be tabulated from the reports have been arranged in the four tables which follow. 
TABLE I. -Statistics of milk supply and supervision in all

\begin{tabular}{|c|c|c|c|c|c|c|c|c|c|c|c|c|c|}
\hline \multirow[b]{2}{*}{ States and cities. } & \multirow{2}{*}{ 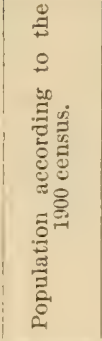 } & \multicolumn{2}{|c|}{$\begin{array}{l}\text { Average } \\
\text { daily milk } \\
\text { consumption. }\end{array}$} & \multirow{2}{*}{ 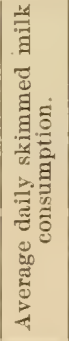 } & \multirow{2}{*}{ 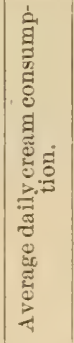 } & \multirow[b]{2}{*}{ 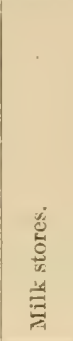 } & \multirow[b]{2}{*}{ 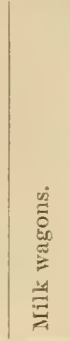 } & \multirow{2}{*}{ 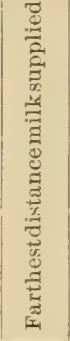 } & \multirow{2}{*}{ 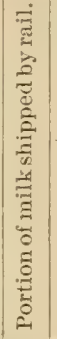 } & \multicolumn{3}{|c|}{$\begin{array}{l}\text { Production of } \\
\text { milk within } \\
\text { eity limits. }\end{array}$} & \\
\hline & & 氶 & 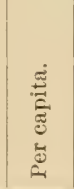 & & & & & & & $\underset{\mathscr{D}}{\stackrel{0}{0}}$ & 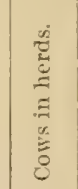 & 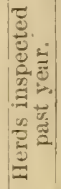 & \\
\hline California: & No. & $\begin{array}{l}\text { Galls. } \\
4,500\end{array}$ & $\begin{array}{l}\text { Pints. } \\
0.35\end{array}$ & Galls. & Galls. & No. & No. & Wiles. & $\mid$ P.et $\mid$ & No. & No. & No & \\
\hline $\begin{array}{l}\text { San Francisco.... } \\
\text { Colorado: }\end{array}$ & 342,782 & 25,000 & $\begin{array}{l}0.58 \\
.58\end{array}$ & 500 & $\begin{array}{r}150 \\
1,500\end{array}$ & 173 & $\begin{array}{l}112 \\
350\end{array}$ & 20 & $\begin{array}{c}0 \\
\ldots\end{array}$ & $\begin{array}{r}25 \\
196\end{array}$ & $\begin{array}{r}500 \\
5,880\end{array}$ & $\begin{array}{r}25 \\
0\end{array}$ & $\begin{array}{l}1 \\
\therefore\end{array}$ \\
\hline $\begin{array}{l}\text { Denver ......... } \\
\text { Connectieut: }\end{array}$ & 133,859 & 12,110 & .65 & 1,000 & 2,000 & 200 & 300 & 40 & 10 & 80 & 900 & 80 & 3 \\
\hline $\begin{array}{l}\text { New Haven...... } \\
\text { Dist. of Columbia: }\end{array}$ & 108,027 & 8,750 & $i .65$ & & . & 400 & 200 & 10 & & & & & 4 \\
\hline $\begin{array}{l}\text { Washington...... } \\
\text { Illinois: }\end{array}$ & 278,718 & 12,500 & .36 & & & 114 & 150 & 92 & ... & 136 & 1,127 & |125 & 5 \\
\hline $\begin{array}{l}\text { Chicago.......... } \\
\text { Indiana: }\end{array}$ & $1,698,575$ & 169,465 & e. 80 . & & & $2,16^{2}$ & 2,692 & 123 & 97 & 30 & 420 & 30 & 6 \\
\hline $\begin{array}{l}\text { Indianapolis..... } \\
\text { Kentucky: }\end{array}$ & 169,164 & 12,000 & .57 & 8,000 & 4,000 & 770 & 273 & 40 & 5 & .25 & 180 & 25 & i \\
\hline $\begin{array}{l}\text { Louisville........ } \\
\text { Louisiana: }\end{array}$ & 204,731 & 10,000 & .39 & 8,000 & 50 & 100 & 250 & 50 & 50 & 100 & 1,000 & 25 & 8 \\
\hline $\begin{array}{l}\text { New Orleans..... } \\
\text { Muryland: }\end{array}$ & 287,104 & 9,609 & .27 & 200 & 75 & 17 & 410 & 83 & 14 & 410 & 6,686 & 440 & 9 \\
\hline $\begin{array}{l}\text { Baltimore........ } \\
\text { Massachusetts: }\end{array}$ & 508,957 & 25,000 & .39 & 5,000 & 4,000 & 2,530 & 525 & 200 & $|\cdots|$ & $5: 9$ & 3,314 & 1539 & 10 \\
\hline Boston ............. & 560,892 & 82,250 & del.17 & & & 2,900 & | 506 & 140 & 75 & 126 & 739 & 126 & 11 \\
\hline Fall River ....... & 104,863 & 6,000 & .46 & 4 & 50 & 327 & 320 & 10 & 0 & 105 & 350 & 105 & 12 \\
\hline $\begin{array}{l}\text { Worcester........ } \\
\text { Michigan: }\end{array}$ & 118,421 & 16,500 & f 1.11 & 200 & 250 & 400 & 350 & 25 & 1 & 310 & 4,036 & 316 & 13 \\
\hline $\begin{array}{l}\text { Detroit........ } \\
\text { Minnesota: }\end{array}$ & 285,704 & 15,000 & .42 & 2,000 & 700 & 700 & 230 & & & 50 & 250 & 25 & 14 \\
\hline Minneapolis ..... & 202,718 & 28,000 & 1.11 & 335 & 3,536 & 400 & 500 & 75 & 20 & & $-91,300$ & 92 & is \\
\hline $\begin{array}{l}\text { St. Paul ........ } \\
\text { Missouri: } \\
\text { Kansas City, in- } \\
\text { cluding Kansas }\end{array}$ & 163,065 & 12,000 & .59 & 1,500 & 1,200 & 400 & 325 & 75 & 20 & & & $\ldots$ & 16 \\
\hline City, Kans .... & 215,170 & 25,000 & .93 & & . & 400 & 420 & 75 & 20 & 40 & 700 & 40 & 17 \\
\hline St. Joseph........ & 102,979 & 8,562 & .66 & 4,290 & 100 & 30 & | 125 & 50 & 12 & 68 & 1,000 & 12 & $1 S$ \\
\hline $\begin{array}{l}\text { St. Louis .......... } \\
\text { Nebraska: }\end{array}$ & 575,238 & 26,375 & .37 & 0 & 3,000 & 1,987 & 1,109 & & & $400(?)$ & 8,000 & 350 & 19 \\
\hline $\begin{array}{l}\text { Omaha......... } \\
\text { New Jersey: }\end{array}$ & 102,555 & $5,7.40$ & .45 & 200 & 140 & 146 & 150 & 75 & 33 & 89 & 2,000 & 89 & 20 \\
\hline Jersey City..... & 206,433 & 12,000 & .47 & 0 & 500 & 150 & 250 & 250 & $90(?)$ & 30 & 275 & 30 & 21 \\
\hline Newark......... & 246,070 & 16,000 & .52 & .... & 1,200 & .800 & 279 & 312 & 60 & 58 & 871 & 58 & 22 \\
\hline I'aterson ........ & 105,171 & 8,000 & .61 & 1. & 200 & 225 & & 12 & 16 & S.t & 423 & $\ldots$ & $2 S$ \\
\hline
\end{tabular}

$u \mathrm{~L}=$ Lactometer. $\mathrm{B}=$ Babcock test. $\mathrm{G}=$ Gravimetric analysis.

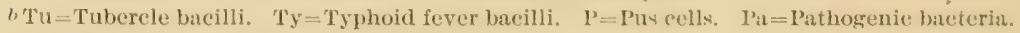

$e$ fortion used in manufacturing butterine.

a Large portion consumed by nonresidents for noon lunch. 
the (3S) cilies of 100,000 or more population (Class $I$ ).

\begin{tabular}{|c|c|c|c|c|c|c|c|c|c|c|c|c|c|c|c|}
\hline & $\begin{array}{l}\text { Dair } \\
\text { beyo } \\
\text { city } 1 \\
\text { its su } \\
\text { plyir } \\
\text { mill }\end{array}$ & $\begin{array}{l}\text { ries } \\
\text { ond } \\
\text { lim- } \\
\text { up- } \\
\text { ng } \\
\text { k. }\end{array}$ & $\begin{array}{l}\text { Ret } \\
\text { pri } \\
\text { milk } \\
\text { qua }\end{array}$ & $\begin{array}{l}\text { tail } \\
\text { ice } \\
\text { per } \\
\text { art. }\end{array}$ & $\begin{array}{l}\text { "Mo } \\
\text { supp }\end{array}$ & $\begin{array}{l}\text { del" d: } \\
\text { lying I }\end{array}$ & $\begin{array}{l}\text { lairies } \\
\text { milk. }\end{array}$ & $\begin{array}{r}M i \\
\operatorname{stan} d\end{array}$ & ard. & $\begin{array}{r}\text { Mil } \\
\text { inspect }\end{array}$ & tion. & Exam & $\begin{array}{l}\text { nations of } \\
\text { past } \mathrm{y}\end{array}$ & $\begin{array}{l}\text { milk } \\
\text { ear. }\end{array}$ & samples \\
\hline & & $\vec{\omega}_{\tilde{\omega}}^{\infty}$ & & & & $\begin{array}{c}\text { Retail } \\
\text { per q }\end{array}$ & $\begin{array}{l}1 \text { price } \\
\text { luart. }\end{array}$ & & & $\vec{\Xi}$ & $\Xi$ & Forcor & position. & For 1 & pacteria. \\
\hline & $\begin{array}{l}\vec{\Xi} \\
\stackrel{\Xi}{0} \\
\text { Ë }\end{array}$ & 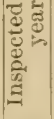 & 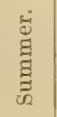 & 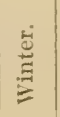 & 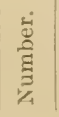 & $\begin{array}{l}\dot{b} \\
\stackrel{\Xi}{\Xi} \\
\dot{a} \\
\dot{\Xi}\end{array}$ & $\underset{\Xi}{\stackrel{E}{3}}$ & $\frac{\tilde{\sigma}}{0}$ & $\stackrel{\Xi}{\tilde{I}}$ & 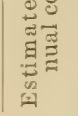 & 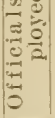 & 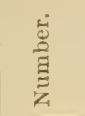 & 总 & $\frac{\stackrel{\leftrightarrow}{0}}{\stackrel{\Xi}{\Xi}}$ & 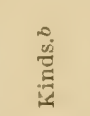 \\
\hline & No. & No. & Cts. & Cts. & & Cts. & $C t s$. & P.ct. & P.ct.! & Dolls. & INo. & & & & \\
\hline 1 & 75 & 75 & 5 & 5 & 1 & $7 \frac{1}{2}$ & $7 \frac{1}{2}$ & 12 & 3.4 & 1,100 & 1 & 419 & I. B. G. & ....... & \\
\hline 2 & 300 & 0 & $5-7$ & $5-7$ & 0 & ....... & $\ldots$ & 12 & 3.2 & & $\ldots$. & 464 & L. B. G. & 3 & Tu. Ty. \\
\hline 3 & 300 & 300 & $5-6 \frac{1}{4}$ & $6 \frac{1}{4}-8 \frac{1}{3}$ & & & & 12 & 3 & 1,200 & 2 & $\begin{array}{r}2,200 \\
600\end{array}$ & $\begin{array}{l}\text { B. } \\
\text { G. }\end{array}$ & Few. & \\
\hline 4 & .. & 12 & 6 & 7 & 6 & 6 & 7 & 11.5 & 3.5 & $\ldots$ & $\ldots$ & 74 & I. B. & $\ldots$ & \\
\hline 5 & 630 ! & 205 & $6-8$ & $6-8$ & 2 & $|10-12|$ & $10-12$ & 12.5 & 3.51 & I.... & 3 & 413 & L. B. G. & 0 & \\
\hline 6 & 4,000 & 11 & $5-7$ & $6-7$ & 2 & $7-12$ & $7-12$ & 12 & 3 & 10,000 & 7 & 19,053 & L. B. G. & 126 & Tu. \\
\hline 7 & 250 & 204 & 5 & 6 & & $\ldots$. & ..... & 12 & 3 & 1,000 & 1 & 850 & I. B. G. & 14 & \\
\hline$s$ & 100 & 25 & $5-6 \frac{1}{4}$ & $\left|5-6 \frac{1}{4}\right|$ & 4 & $6 \frac{1}{4}-7 \frac{1}{2}$ & $\left|6 \frac{1}{4}-7 \frac{1}{2}\right|$ & 12 & 3 & & 3 & 475 & G. & 0 & \\
\hline 9 & 69 & 27 & $7 \frac{1}{2}$ & $7 !$ & 3 & 10 & 10 & 13 & 3.5 & & .. & 1,141 & L. B. G. & 2 & Tu. \\
\hline 10 & 1,500 & 220 & $5-10$ & $5-10$ & 3 & $8-10$ & $8-10$ & 12 & 3 & 2,300 & 3 & $\left\{\begin{array}{r}900 \\
31,803\end{array}\right.$ & $\begin{array}{c}\text { B. G. } \\
\text { L. }\end{array}$ & 300 & P.Tu. \\
\hline 11 & & & $5-8$ & $5-8$ & 20 & $5-8$ & $5-8$ & $\left\{\begin{array}{l}13 \\
12\end{array}\right.$ & $\begin{array}{l}3.7 \\
3\end{array}$ & 13,000 & 6 & 15,000 & L. B. G. & 0 & \\
\hline 12 & 240 & 240 & $5-6$ & $6-7$ & 5 & 7 & 7 & 12 & 3 & 1,250 & 1 & 257 & B. & 0 & \\
\hline 13 & 568 & .... & $5 \frac{1}{4}$ & $5 \frac{1}{2}$ & 25 & 7 & 8 & .... & ..... & 1,000 & 3 & 1,400 & L. B. G. & 200 & \\
\hline 14 & 500 & $\ldots$. & 5 & 6 & 3 & 7 & 81 & 12.5 & 3 & 1,000 & 2 & 1,219 & L. B. G. & 12 & Tu. Ty. \\
\hline 15 & & 99 & 5 & $5-6$ & & & & 13 & 3.5 & 5,000 & 5 & $3,0 \geq 2$ & B. G. & Few. & \\
\hline 16 & & $\ldots$ & 5 & 6 & 0 & ... & $\ldots$ & 13 & 3.5 & 2,000 & $\ldots$ & 500 & L. B. G. & 0 & \\
\hline 17 & 210 & 200 & 5 & $5 ?$ & 3 & 6 & 6 & 12 & 3 & 2,500 & 2 & 2,500 & B. G. & 125 & Tu. \\
\hline 18 & ..... & 18 & 5 & $6 \frac{2}{3}$ & 0 & $\ldots$. & ... & 12 & 3 & ....... & 1 & 6 & L. & 0 & \\
\hline 19 & 119 & .... & $5-8$ & $5-8$ & 3 & $12 \frac{1}{2}$ & $12 \frac{1}{2}$ & 11.5 & 3 & 1,850 & 1 & 684 & L. B. & 72 & Ty. \\
\hline 20 & ...... & 15 & 5 & 6 & & & & 12 & 3 & 1,200 & 1 & 460 & B. & & \\
\hline 21 & & & $6-8$ & $7-8$ & 0 & & & & & $h \mathrm{~S}$. & & 500 & L. G. & 0 & \\
\hline 22 & 500 & .... & 6 & 7 & Few. & $8-12$ & S-12 & 12 & ...... & 2,000 & 3 & $\left\{\begin{array}{r}283 \\
3,508\end{array}\right.$ & $\begin{array}{l}\text { L. B. G. } \\
\text { L. }\end{array}$ & 0 & \\
\hline 2.3 & & (1) & $6-8$ & $6-8$ & 2 & 111 & 12 & & & & - & 0 & te & & \\
\hline
\end{tabular}

e There are 506 licenses, but some persons run several wagons on one license.

$f$ Portion consumed by inhabitants of near-by towns and eities.

$g$ Besides 1,200 cows kept by private families.

$h$ State control.

$i$ Tourists, ete., make average jopulation 150,000 . 
TABLE I. - Statistics of milk supply and supervision in all the

\begin{tabular}{|c|c|c|c|c|c|c|c|c|c|c|c|c|c|}
\hline \multirow[b]{2}{*}{ States and cities. } & \multirow{2}{*}{ 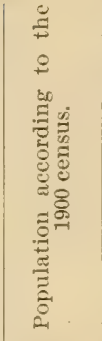 } & \multicolumn{2}{|c|}{$\begin{array}{c}\text { Average } \\
\text { daily milk } \\
\text { consumption. }\end{array}$} & \multirow{2}{*}{ 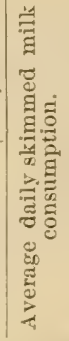 } & \multirow{2}{*}{ 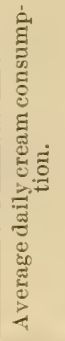 } & \multirow[b]{2}{*}{ 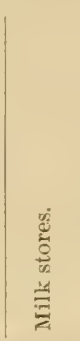 } & \multirow[b]{2}{*}{ 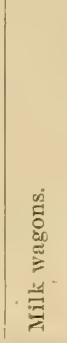 } & \multirow{2}{*}{ 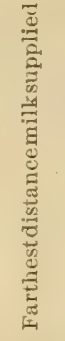 } & \multirow{2}{*}{ 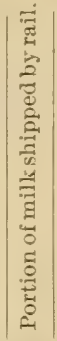 } & \multicolumn{3}{|c|}{$\begin{array}{l}\text { Production of } \\
\text { milk within } \\
\text { eity limits. }\end{array}$} & \\
\hline & & 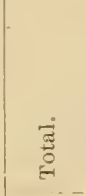 & 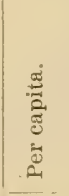 & & & & & & & 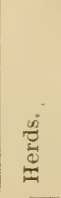 & 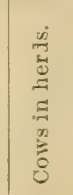 & 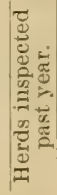 & \\
\hline $\begin{array}{l}\text { New York: } \\
\text { Buffalo .......... }\end{array}$ & $\begin{array}{c}\text { No. } \\
352,387\end{array}$ & $\begin{array}{l}\text { (ivills. } \\
31,000\end{array}$ & $\begin{array}{l}\text { Pints. } \\
0.70\end{array}$ & $\begin{array}{l}\text { finll|s: } \\
\mid 10,000\end{array}$ & livills. & $\begin{array}{c}\text { Vir. } \\
1,200\end{array}$ & $\begin{array}{l}\text { Yis. } \\
529\end{array}$ & Miles. & P.et & $\begin{array}{l}\text { Sn. } \\
22\end{array}$ & $\begin{array}{l}\text { Nis. } \\
310\end{array}$ & Vis. & 24 \\
\hline New York.. & $3,437,202$ & 333,856 & .78 & 0 & 4,000 & 12,000 & 4,000 & 350 & 85 & 5,500 & 23,200 & 560 & 25 \\
\hline Rochester....... & 162,608 & 17,000 & .83 & & ..... & 75 & 275 & 45 & 67 & .6 & 90 & 6. & 26 \\
\hline Syracuse ....... & 108,374 & 10,200 & .75 & 800 & 250 & 340 & 195 & 8 & 1 & 14 & 176 & 14 & 27 \\
\hline $\begin{array}{l}\text { Ohio: } \\
\quad \text { Cincinnati... }\end{array}$ & $325,90^{\circ}$ & 25,000 & .61 & $\ldots$ & ..... & 200 & 200 & 100 & 25 & 40 & $1,-100$ & 40 & $2 S$ \\
\hline Cleveland....... & 381,768 & 21,490 & .45 & 1,000 & 500 & 1,200 & 580 & 65 & $\ldots$ & 31 & 225 & 31 & $\approx 9$ \\
\hline Columbus.... & 125,560 & 6,397 & .41 & & & 134 & 286 & 40 & & & & & 30 \\
\hline Toledo........... & 131,822 & 9,650 & .59 & & & 221 & 253 & so & 33 & 41 & 769 & 41 & 31 \\
\hline $\begin{array}{l}\text { Pennsylvauia: } \\
\text { Allegheny ... }\end{array}$ & 129,896 & 5,000 & .31 & & & 160 & 400 & 150 & 67 & 38 & 500 & 38 & 32 \\
\hline Philadelphin .. & $1,293,697$ & 75,000 & .46 & & & 1,500 & 2,600 & 200 & $|75(?)|$ & 500 & 5,000 & 500 & 38 \\
\hline Pittsburg ........ & 321,616 & 30,000 & .75 & & & 1,230 & 425 & 50 & 30 & 211 & & $\ldots$ & 314 \\
\hline Scranton........ & 102,026 & 7,000 & .55 & .. & & 170 & 125 & 30 & .... & 2 & 25 & 0 & 35 \\
\hline $\begin{array}{l}\text { Rhode Island: } \\
\text { Providenee . . }\end{array}$ & 175,597 & 22,000 & 11.00 & & & 1,200 & 500 & 60 & 33 & & & & 36 \\
\hline $\begin{array}{l}\text { Tennessee: } \\
\text { Memphi॰........ }\end{array}$ & 102,$2 ; 211$ & (i., 400 & .50 & & & 111 & 11iin & 527 & & & & & $\therefore$ \\
\hline $\begin{array}{l}\text { W1seonsin: } \\
\text { Milwaukee ...... }\end{array}$ & 285,315 & 25,000 & .70 & ....... & $60^{0}$ & 500 & 600 & 72 & 25 & 117 & 613 & 70 & $3 s$ \\
\hline $\begin{array}{l}\text { Average of } \\
\text { those re- } \\
\text { porting. }\end{array}$ & 375,257 & 30,930 & .61 & 2,152 & 1,273 & 968 & 550 & 105 & 38 & 297 & 2,260 & 124 & $\therefore:$ \\
\hline
\end{tabular}

a Portion used in manufacturing butterine. 
(38) cities of 100,000 or more population (Class I) -Continuer.

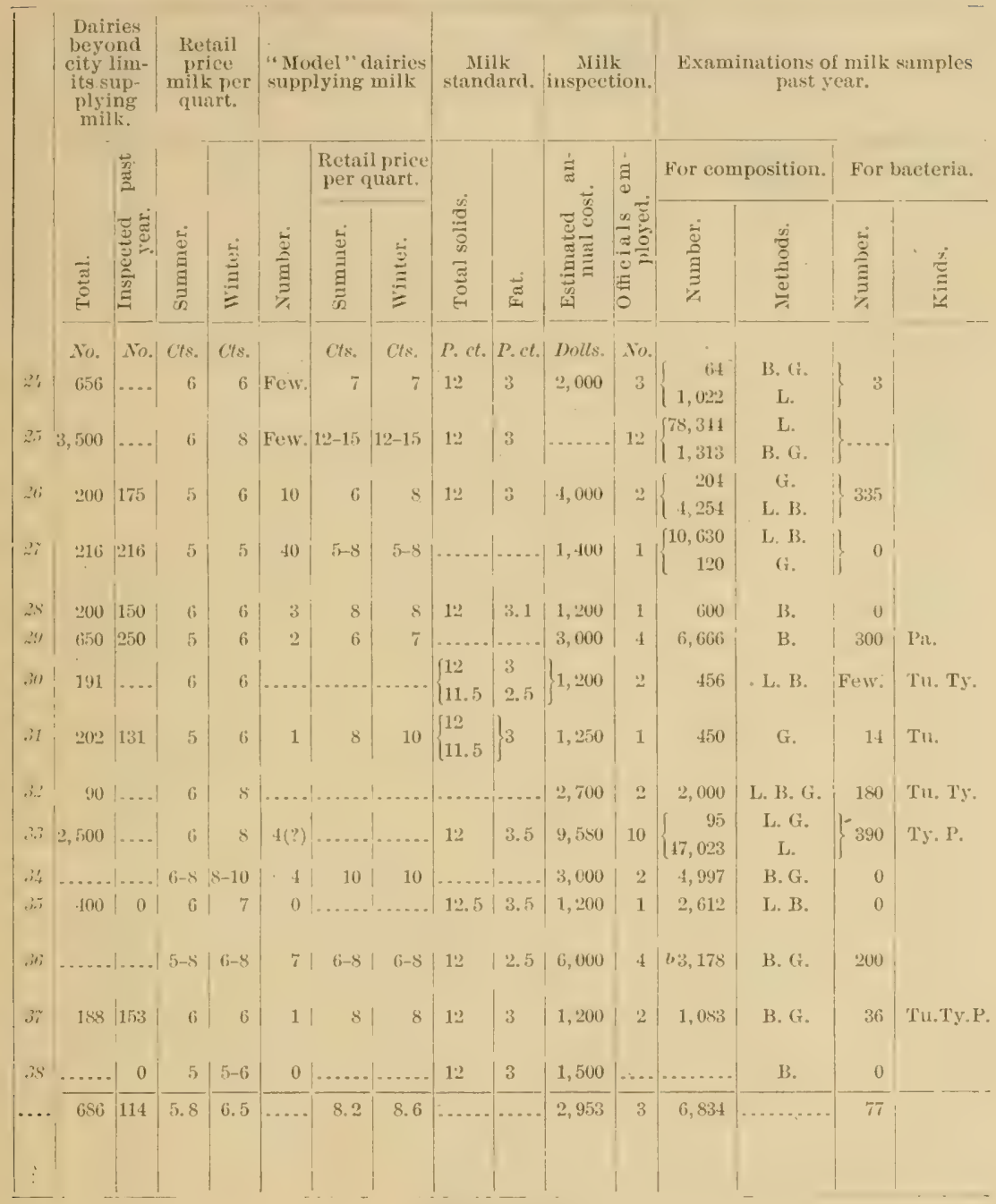

$b$ For five months. 
TABLE II.-Statistics of mille supply and stpervision in all of the (40)

States and citics.

\section{California: \\ Oakland \\ Connecticut: \\ Bridgeport \\ Hartford \\ Delaware: \\ Wilmington..... \\ Georgia: \\ Atlanta. \\ Sayannah....... \\ Illinois: \\ Peoria}

Indiana:

Evansville

Iowa:

Des Moines

Kansas:

Kansas City

Maine:

Portland

Massachusetts:

Cambridge.......

Lawrence........

Lowell ............

Lymn ...........

New Bedford ....

Somerville.

Springfield

Michigan:

Grand Rapids...

Minnesota:

Duluth

New Hampshire:

Manchester

New Jersey:

Camden

Elizabeth........

Hoboken

Trenton.

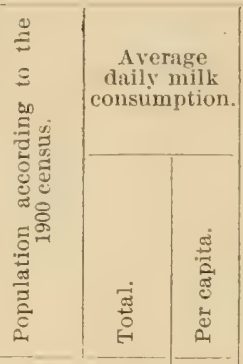

No. 66,960

70,996

79,850

$76.50 \mathrm{~s}$

80,872

\begin{tabular}{l|l}
89,872 & $e$ \\
\hline & 1,500
\end{tabular}

$54,241 \quad 3,000$

\begin{tabular}{l|l}
56,100 & 5,000
\end{tabular}

59,007

2,500

62,139

5,000

51,418

50,145

\begin{tabular}{l|l}
91,886 & $h 9,07.4$
\end{tabular}

62,559

94,969

6,000

7,700

68,513

\begin{tabular}{ll|l|l|}
6,000 & .70 & 600 & 125
\end{tabular}

62,442

61,643

62,059

7,000

$.90 \mid \ldots . . . . . . .6$

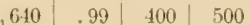

4,750

87,565

52,969

56,087

75,935

52,130

59,364

73,307

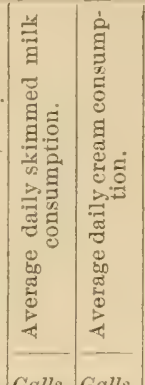

4,000

4, 000

\begin{tabular}{r|r|r|r|}
8,750 & $k 1.21$ & $\ldots \ldots$
\end{tabular}
它

No.

45

$200|250|$

$53 \mid 195$

$55 \quad 341$

10 350

10

45

3

40

0

100

200

75

156

410

700

350

350

201

300

103

51

45

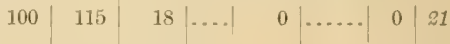

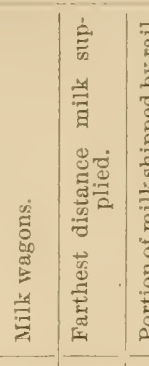

Production of

milk within

city limits.

o. Miles. P.et No. No. No,

\begin{tabular}{l|l|l|l|l|l|l|}
80 & 40 & $\ldots$ & 45 & 3,500 & 45 & 1
\end{tabular}

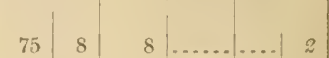

\begin{tabular}{l|l|l|l|l|l|}
20 & 3 & 20 & 300 & 20 & 3
\end{tabular}

\begin{tabular}{l|l|l|l|l|l|}
40 & 50 & 9 & 85 & 0 & 4
\end{tabular}

$20 \quad 20$

5: 0

\begin{tabular}{l|l|l|l|l|l|l}
80 & 50 & 4 & 23 & 416 & 23 & 7
\end{tabular}

\begin{tabular}{l|l|l|l|l|l|l}
60 & 9 & 0 & 5 & 60 & 5 & $s$
\end{tabular}

\begin{tabular}{l|l|l|l|l|l|l}
125 & 40 & $\ldots$ & 75 & 1,000 & $\ldots$ & 9
\end{tabular}

\begin{tabular}{l|l|l|l|l|l|l}
75 & 40 & $\ldots$ & 42 & 1,000 & 42 & 10
\end{tabular}

\begin{tabular}{|l|l|l|l|l|l|l|}
156 & 100 & 53 & 76 & 234 & 76 & 12 \\
\hline
\end{tabular}

\begin{tabular}{|l|l|l|l|l|l|l|}
200 & 12 & $\ldots$ & 8 & 130 & 8 & 18
\end{tabular}

\begin{tabular}{l|l|l|l|l|l|l|}
156 & 20 & 4 & $\ldots$. & 100 & $\ldots$. & 14 \\
\hline
\end{tabular}

\begin{tabular}{l|l|l|l|l|l|l|}
75 & 300 & 67 & 60 & 350 & 60 & 15
\end{tabular}

\begin{tabular}{|l|l|l|l|l|l|l|}
170 & 20 & $\ldots$ & 20 & 700 & 20 & 16 \\
\hline
\end{tabular}

\begin{tabular}{l|l|l|l|l|l|l|}
185 & 175 & 87 & 2 & 62 & 2 & 17
\end{tabular}

\begin{tabular}{|l|l|l|l|l|l|l|}
133 & 14 & 0 & 20 & $i 130$ & $\ldots .$. & 18
\end{tabular}

\begin{tabular}{l|l|l|l|l|l|l}
2,28 & 100 & 5 & $\ldots$ & 1,000 & $\ldots$ & 19
\end{tabular}

\begin{tabular}{l|l|l|l|l|l|l|}
95 & 155 & 33 & 100 & 1,100 & 100 & 20
\end{tabular}

\begin{tabular}{l|l|l|l|l|l|l|l}
128 & 75 & 30 & $(j)$ & 0 & $\ldots$ & 0 & $\mathbf{2 2}$
\end{tabular}

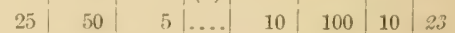

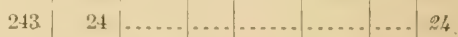

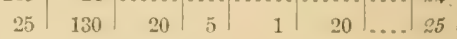

$a \mathrm{~S} .=$ State control.

$b \mathrm{~L}$. = lactometer. G. =gravimetrie analysis. $\mathrm{B}_{\text {. }}=$ Babeock test.

a A portion is consumed by nonresidents.

d Many.

$c$ Besides 2,500 gallons of buttermilk.

$f$ Nearly all. 
cities of over 50,000 and under 100,000 population (Class II).

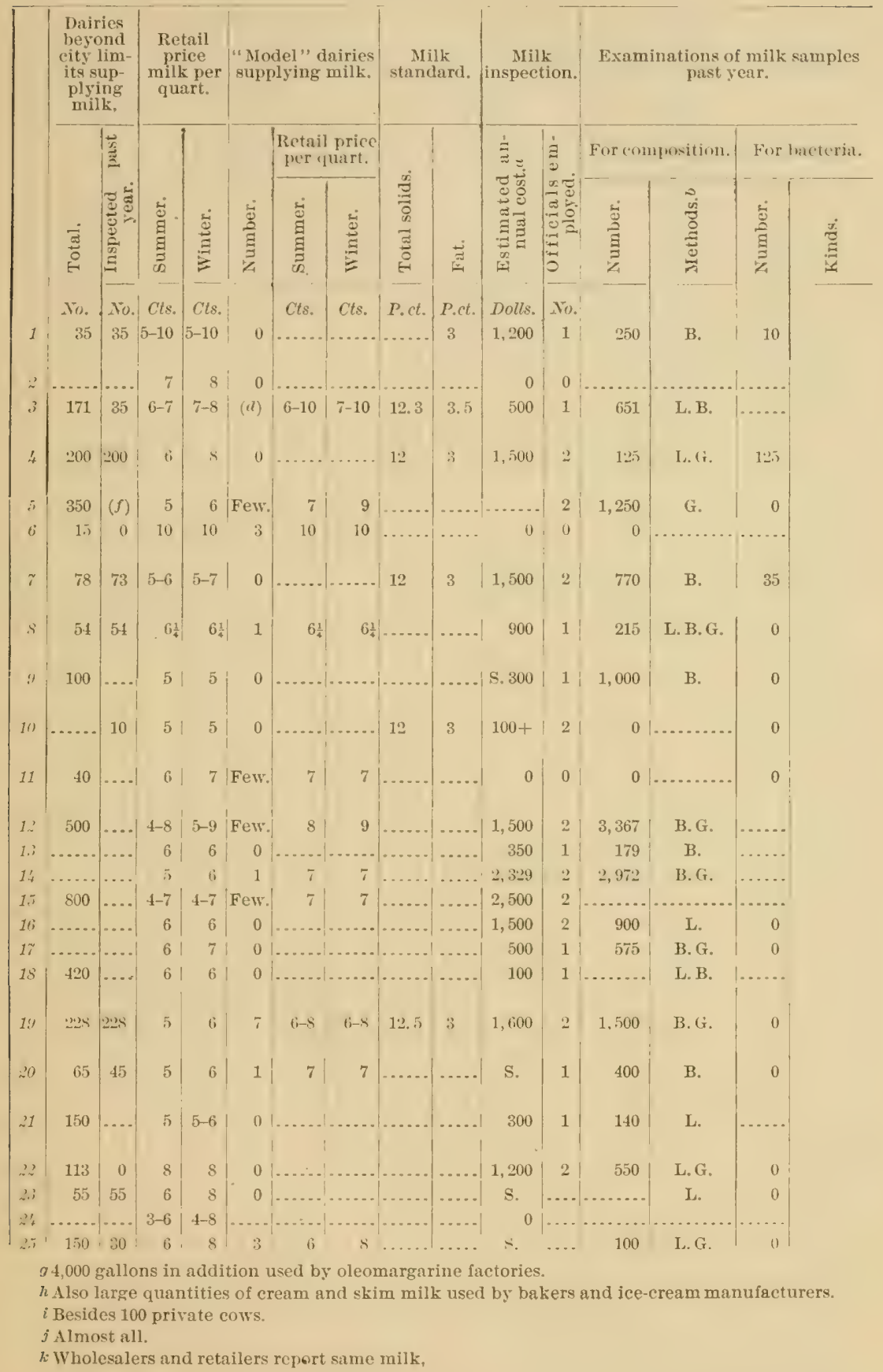


TABLE II.-Statistics of milk supply and supervision in wll of the (40)

States and cities,

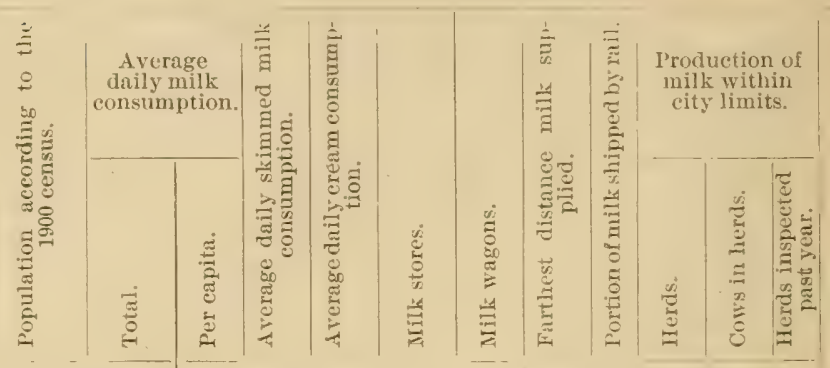

New Tork:

Albany -.........

No. | Galls. Pints.|Galls. Galls. | No.

No. Miles.'P.ct No. No. $\mid$ No.

Troy (and Lan$94,151|8,022| 0.65|1,468| 213|105|$ singburg).

Utica.

$73,246 \mid 6,000$

Ohio:

Dayton.

Oregon:

Portland.

Pennsylvania:

Erie .............

Harrisburg .......

Reading . .

Wilkesbarre

\begin{tabular}{l|l}
56,343 & 5,000 \\
\hline
\end{tabular}

$.60|750|$

South Carolina:

Charleston .

$85,333 \mid 6,500$

\begin{tabular}{l|l|l|l|}
.71 & 300 & $150 \mid$ & 60
\end{tabular}

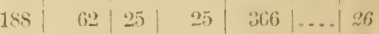

Tennessee:

Nashville

Texas:

San Antonio....

$90,426 \div 7,500$

Ttah:

Salt Lake City ..

Virginiat:

Richmond.

Washington:

Seattle

Arerage of
those report-
ing.

52,733

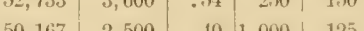

\begin{tabular}{l|l|l|l|l|}
78,961 & 4,200 & .43 & 1,400 & 175
\end{tabular}

\begin{tabular}{|l|l|l|l|l|}
51,721 & 2,890 & .45 & $\ldots .$. & $\ldots$. \\
\hline
\end{tabular}

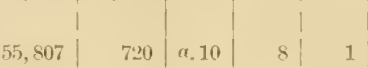

$60 \quad 210$

|

\begin{tabular}{l|l|l|l|l}
$80,86.5$ & 6,802 & .67 & $\ldots \ldots$. & $\ldots .$. \\
& & & &
\end{tabular}

13

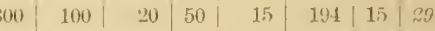

25 $\mid$\begin{tabular}{l|l|l|l|l|l|} 
& $150 \mid$ & $\mathrm{s}$ & 0 & 45 & $210+20 \mid 30$
\end{tabular}

\begin{tabular}{ll|l|l|l|l|l|l|}
$1 \geq 3$ & 78 & 15 & 0 & 3 & 25 & 3 & 31
\end{tabular}

\begin{tabular}{l|l|l|l|l|l|l|l|}
12 & 75 & 15 & 8 & 2 & 20 & $\ldots$ & 32
\end{tabular}

\begin{tabular}{l|l|l|l|l|l|l|l}
20 & 145 & 8 & 0 & 0 & $\ldots \ldots$ & 0 & 33
\end{tabular}

\begin{tabular}{l|l|l|l|l|l|l|l}
40 & 60 & 130 & 50 & 0 & $\ldots .$. & 0 & 34
\end{tabular}

....

$6|\quad 5| 0|\ldots \ldots| \ldots \ldots|\ldots| 35$
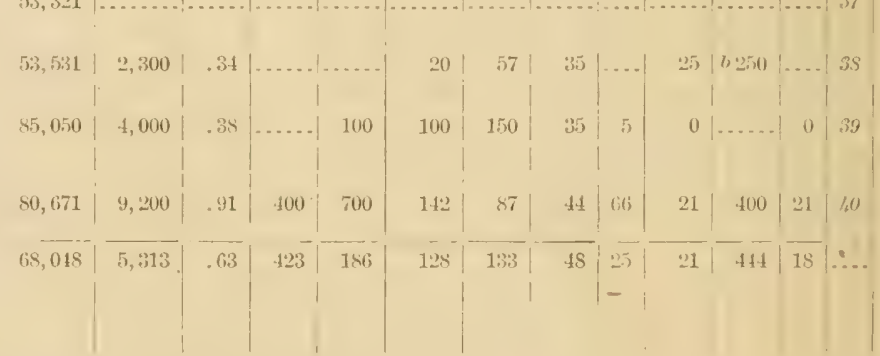

a Large number of private cows kept and no record of inilk sold from these.

b 1,000 gallons are produced by private cows. 
cities of over 50,000 and under 100,000 population (Class II) -Continuer.

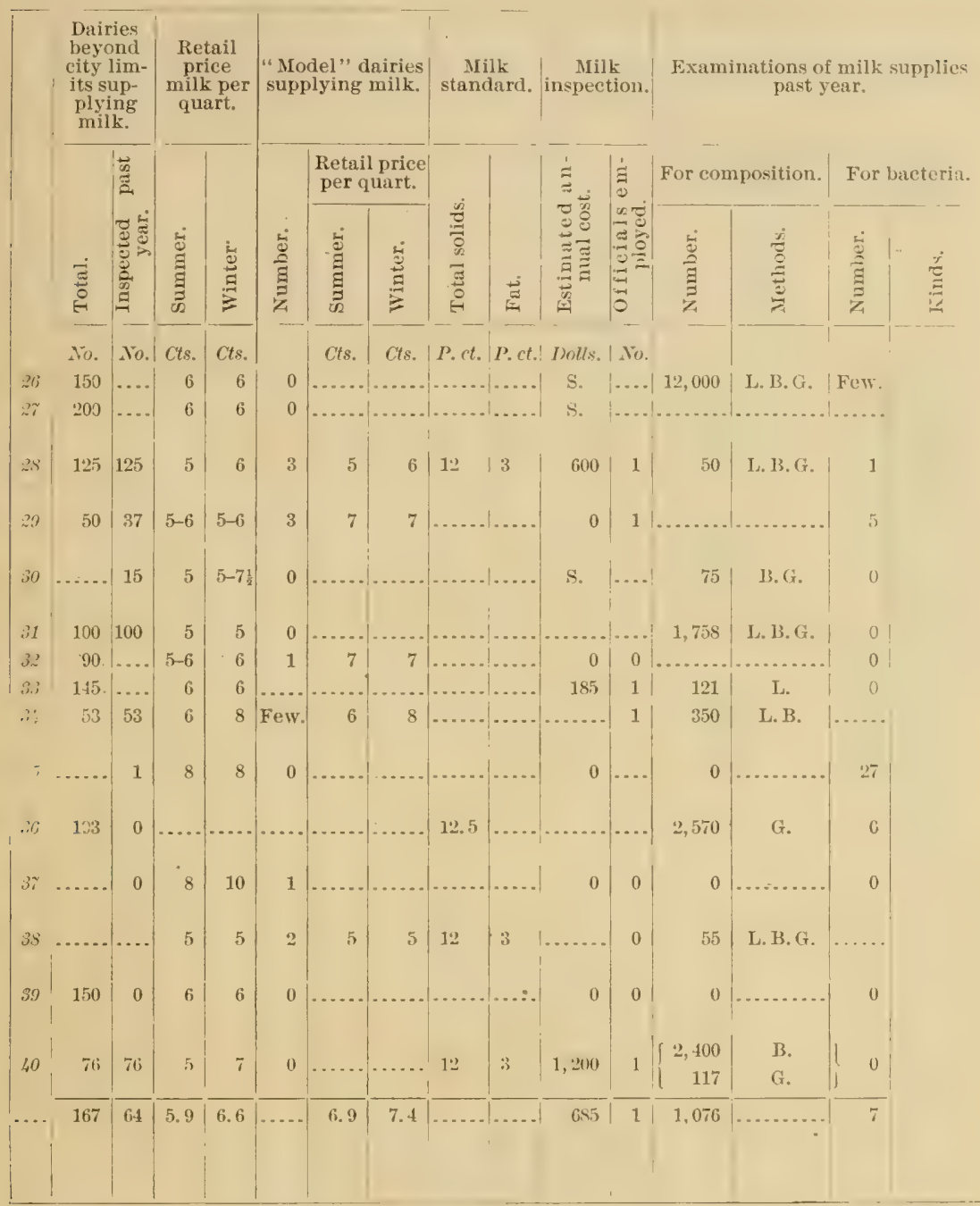

$25839-$ No. $46-03-3$ 
TABLE III.-Statistics of milk supply and supervision in (S3)

States and cities.

\section{Alaham :}

Birmingham .

Mobile...........

Montgomery .....

Arkansas:

Little Rock ......
Californin:
Sacramento......
Colorado:
Prueblo...........

Connecticut:

New Britain .....

Waterbury ........

Florida:

Jacksonville .....

Georgia:

\section{Augusta ...}

Hawaii:

Honolulu

Illinois:

East St. Louis...

Joliet

Quiney ............

Rockford $h \ldots . .$. .

Springfield .......

Indiana:

Fort Wayne...

South Bend.....

Terre Haute ..... Iowa:

Cedar Rapids....

Council Bluffs ..

Davenport ........

Dubuque.

Sioux City .......

Kansas:

Topek ..........

Kentucky:

Covington

Lexington .......

Ninumet.

1.ivint .......

$a S_{2}=$ State control

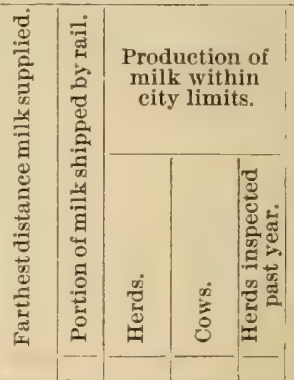

No, | Galls. |Pints. Galls. Galls.| No. No. Miles. P.et No. No. No.

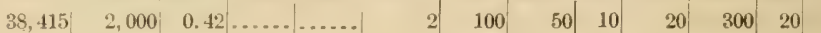

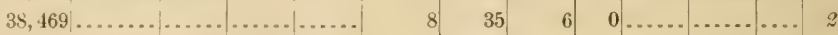

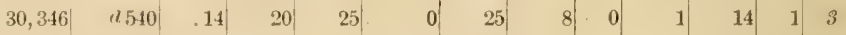

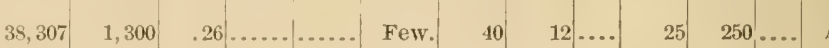
\begin{tabular}{ll|l|l|r|r|r|r|r|r|r}
29,282 & 3,000 & 82 & $\ldots \ldots$ & 50 & 15 & 55 & 7 & $\ldots$ & 0
\end{tabular}

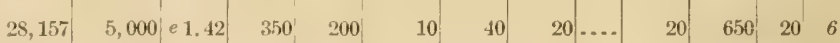
\begin{tabular}{lllllllll|l|l|l}
25,998 & 1,500 & .46 & 50 & 10 & 0 & 30 & $\ldots \ldots$ & $\ldots$ & 1 & $\ldots \ldots$
\end{tabular}

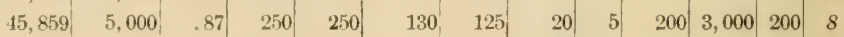
$28,429 \quad 1,200 \quad .34 \ldots \ldots . \ldots$.

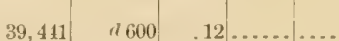

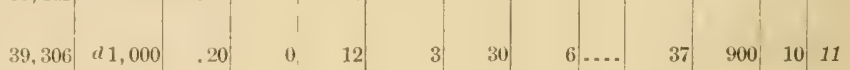

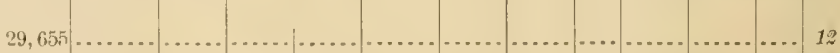
$\begin{array}{llllllllllll}29,353 & 2,400 & .65 & 0 & 15 & 8 & 55 & 5 & 0 & 0 & \ldots \ldots & \ldots\end{array}$

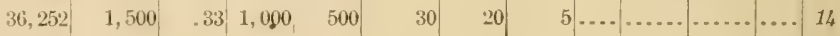

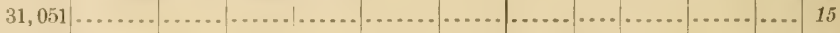

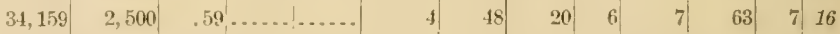

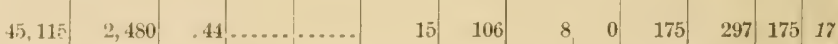
$35,998 \quad 1,000 \quad .22 \ldots \ldots . . . . .$. $36,675 \quad 1,000 \quad .22 \quad 40 \quad 30$

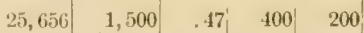

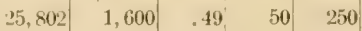
\begin{tabular}{lll|l|l|}
35,254 & 1,400 & .32 & 500 & 150
\end{tabular} \begin{tabular}{l|l|l|l|l|}
36,297 & 1,425 & .31 & $\ldots \ldots$ & 150
\end{tabular} $33,111 \quad 4,500 \mid g 1.09 \ldots \ldots . . . .$. \begin{tabular}{l|l|l|l|l|}
33,608 & 2,000 & .48 & 50 & 80
\end{tabular}

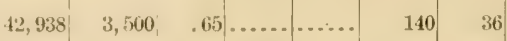

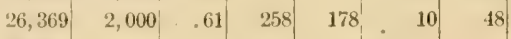
29,301

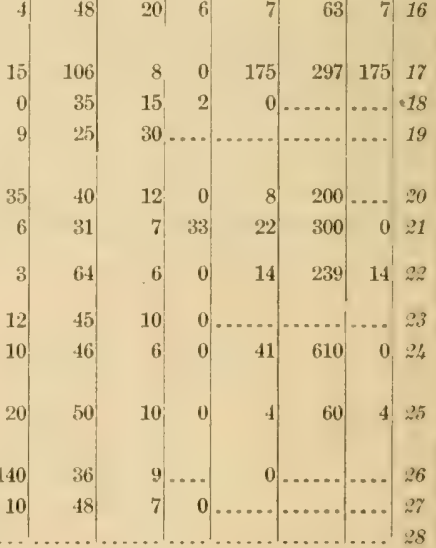

‘Tu. Tuherele bacilli. Ty.=Typhoid fever bacilli. P.=Pus cells. Pa.=Pathogenie baeteria. J)ip.=1)iphtheria, 
MILK SUPPLY OF TWO HUNDRED CITLES.

cities of over 25,000 and under 50,000 population (Class III).

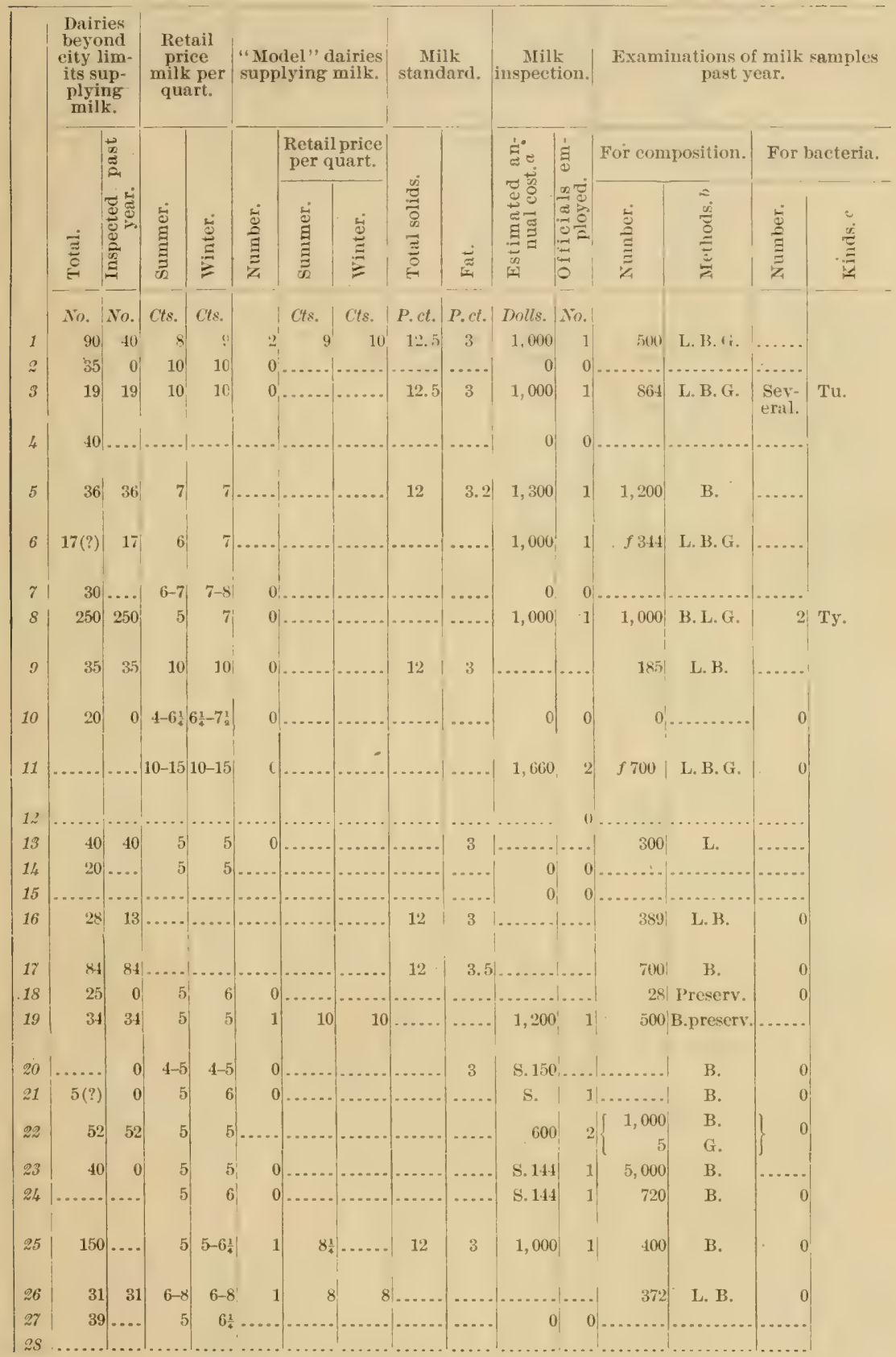

$d$ Large number of private cows kept and milk sold; no record.

$e$ Claim population is 47,955 .

$f$ Samples examined in 9 months.

y Claim population is over 35,000 .

$h$ No inspector and no records; can get no facts. 
TABLE III.-Statzstics of milk supply and supervision in (83)

\begin{tabular}{|c|c|c|c|c|c|c|c|c|c|c|c|c|c|}
\hline \multirow[b]{2}{*}{ States and cities. } & \multirow{2}{*}{ 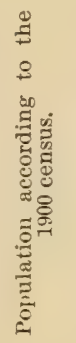 } & \multicolumn{2}{|c|}{$\begin{array}{c}\text { Arerage } \\
\text { daily milk } \\
\text { consumption. }\end{array}$} & \multirow{2}{*}{ 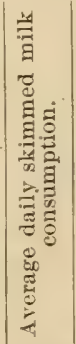 } & \multirow{2}{*}{ 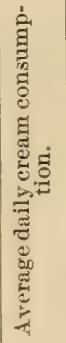 } & \multirow[b]{2}{*}{ 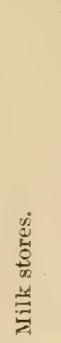 } & \multirow[b]{2}{*}{ 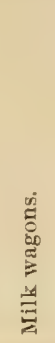 } & \multirow{2}{*}{ 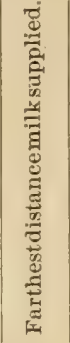 } & \multirow{2}{*}{ 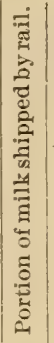 } & \multicolumn{3}{|c|}{$\begin{array}{l}\text { Production of } \\
\text { milk within } \\
\text { city limits. }\end{array}$} & \\
\hline & & 远 & 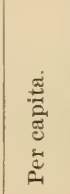 & & & & & & & $\stackrel{\mathscr{B}}{\mathscr{D}}_{\mathscr{B}}^{\dot{B}}$ & $\stackrel{w}{5}$ & 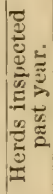 & \\
\hline $\begin{array}{l}\text { Massachusetts: } \\
\text { Brockton .... }\end{array}$ & $\begin{array}{c}\text { No. } \\
40,063\end{array}$ & $\begin{array}{l}\text { Galls:- } \\
3,200\end{array}$ & $\begin{array}{c}\text { Pints. } \\
0.61\end{array}$ & $\begin{array}{c}\text { Galls. } \\
50\end{array}$ & $\begin{array}{c}\text { Galls. } \\
40\end{array}$ & $\begin{array}{l}\text { No. } \\
150\end{array}$ & $\begin{array}{l}\text { No. } \\
150\end{array}$ & $\begin{array}{c}\text { Miles. } \\
16\end{array}$ & P.ct & $\begin{array}{r}\text { No. } \\
41\end{array}$ & $\begin{array}{l}\text { No. } \\
584\end{array}$ & $\left\{\begin{array}{l}\text { No. } \\
41\end{array}\right.$ & 29 \\
\hline Chelsea ....... & 34,072 & 3,800 & \begin{tabular}{|l}
.89 \\
\end{tabular} & 100 & 40 & 179 & 46 & ..... & .... & 15 & 140 & 15 & 30 \\
\hline Fitchburg... & 31,531 & 4,541 & 1.15 & & 45 & 99 & 126 & 12 & $\ldots$. & 34 & 404 & 34 & 31 \\
\hline Gloucester . & 26,121 & 2,300 & .70 & 0 & 125 & 124 & 88 & 16 & $\ldots$. & 50 & 700 & 50 & 32 \\
\hline Haverhill... & 37,175 & 3,290 & $.7 \mathrm{~L}$ & & ..... & 120 & 100 & 10 & .... & 120 & 1,000 & 120 & 33 \\
\hline Holyoke..... & 45,712 & 4,373 & .77 & 488 & 63 & 172 & 136 & 16 & .... & 78 & 858 & 78 & 34 \\
\hline Malden ...... & 33,664 & 3,000 & .71 & & .... & 95 & 45 & 75 & 50 & 25 & 183 & (a) & 35 \\
\hline Newton.... & 33,587 & 5,275 & 1.25 & & 32 & 140 & 130 & 50 & $\cdot \frac{1}{2}$ & 41 & 1,170 & 41 & $\$ 6$ \\
\hline Salem ........ & 33,956 & 4,200 & .93 & & 33 & 80 & 61 & 12 & .... & 6 & 185 & .... & 37 \\
\hline Taunton ....... & 31,036 & 2,532 & .65 & & & 26 & 135 & 9 & $0 \mid$ & 77 & 810 & 77 & 38 \\
\hline \multicolumn{14}{|l|}{ Michigan: } \\
\hline Bay City ......... & 27,628 & 3,000 & .87 & & . & 8 & 28 & 6 & $\ldots$. & 3 & 40 & 3 & 39 \\
\hline Jackson City ..... & 25,180 & 1,745 & .55 & ... & .... & 60 & 52 & $6 \frac{1}{8}$ & $\ldots$ & 8 & 55 & 8 & $\angle 0$ \\
\hline Saginaw ......... & 42,345 & & & & & & & & & & & $\ldots$ & 41 \\
\hline \multicolumn{14}{|l|}{ Missouri: } \\
\hline $\begin{array}{l}\text { Joplin............. } \\
\text { Montana: }\end{array}$ & 26,023 & 3,500 & .56 & 50 & 25 & -21 & 32 & 20 & -... & 1 & 25 & $\ldots$ & 42 \\
\hline - Butte ............ & 30,470 & 7,000 & .75 & 1,000 & 100 & 12 & 35 & 12 & 4 & 0 & & $\ldots$ & 43 \\
\hline \multicolumn{13}{|l|}{ Nebraska: } & 44 \\
\hline South Omaha.... & 26,001 & 1,108 & .34 & 30 & 60 & 2 & 27 & 30 & .... & 4 & 71 & 4 & 45 \\
\hline \multicolumn{14}{|l|}{ New Jersey: } \\
\hline Atlantie City .... & 27,838 & & ..... & & & 30 & 50 & $50^{\circ}$ & 100 & 0 & $\cdots .$. & $\cdots$ & 46 \\
\hline Bayonne......... & 32,772 & 1,800 & .50 & & & 130 & 35 & 40 & $\ldots$ & 4 & 125 & 4 & 47 \\
\hline Passaic.......... & 27,777 & & & & & & & 100 & 70 & 43 & 122 & 43 & $4 S$ \\
\hline \multicolumn{14}{|l|}{ New York: } \\
\hline Auburn ........ & 30,345 & 3,000 & .79 & 50 & 50 & 4 & 60 & 6 & 0 & 5 & 230 & .... & 49 \\
\hline Binghamton ..... & 39,647 & 2,520 & .51 & 215 & 250 & 50 & 72 & 10 & $\ldots$ & 0 & ...... & .... & 50 \\
\hline Elmira ........... & 35,672 & 5,000 & 1.12 & & ...... & 25 & 100 & 6 & $\cdots$ & 8 & 170 & $\cdots$ & 51 \\
\hline Schenectady ..... & 31,682 & 2,000 & .51 & .... & .... & 8 & 34 & 18 & 13 & 3 & 20 & 0 & 52 \\
\hline Yonkers ......... & 47,931 & 4,000 & .67 & 0 & 40 & 208 & 56 & 85 & 50 & 28 & 648 & 28 & 53 \\
\hline \multicolumn{14}{|l|}{ Ohio: } \\
\hline Akron............. & 42,728 & 3,000 & .56 & & 100 & 75 & 88 & 20 & 13 & 2 & 25 & 2 & 54 \\
\hline Canton....... & 30,667 & 2,000 & .52 & & & & 70 & 10 & 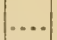 & 3 & 41 & 3 & 55 \\
\hline Springfield....... & 38,253 & ........ & ..... & & & & .... & 8 & & -.. & & $\ldots$ & 56 \\
\hline Youngstown ..... & 44,885 & 2,000 & .36 & & & 45 & 60 & 15 & .... & 0 & & 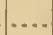 & 57 \\
\hline \multicolumn{14}{|l|}{ Pennsylvania: } \\
\hline Allentown ...... & 35,416 & & & & & & & & & & & & 58 \\
\hline Altoona .......... & 38,973 & 3,500 & .72 & & ..... & 25 & 40 & 15 & $50 \mid$ & 2 & 20 & $10 .$. & 59 \\
\hline
\end{tabular}


cities of over 25,000 and under 50,000 population (Class III)-Continued.

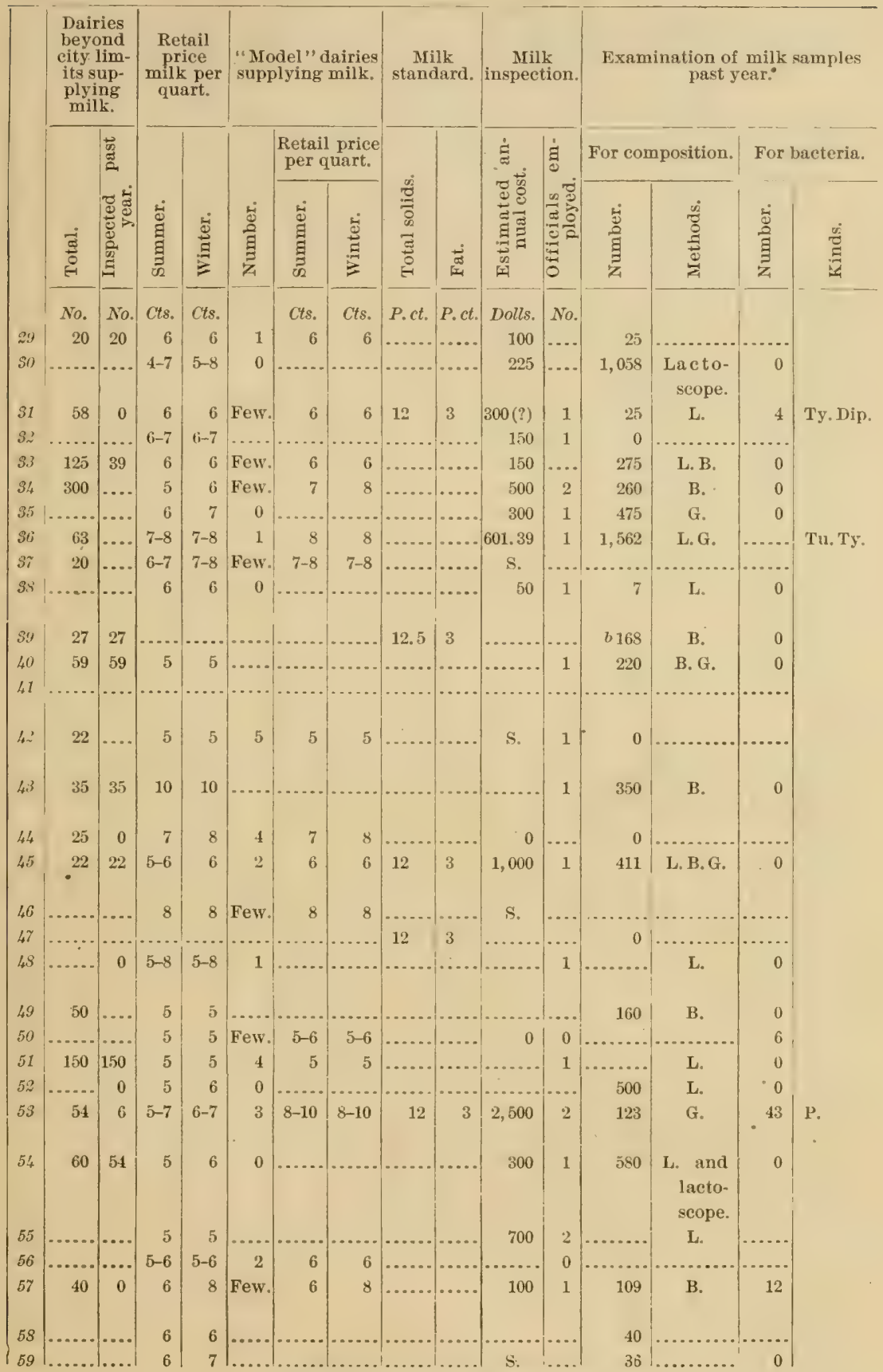

$\checkmark$ Samples cxamined in 9 months. 
'TABLE III.-Slatistics of milk supply and supervision in (83)

States and eitics.

\begin{tabular}{|c|c|c|}
\hline$\stackrel{8}{\sharp}$ & \multicolumn{2}{|c|}{$\begin{array}{l}\text { Average } \\
\text { daily milk } \\
\text { consumption }\end{array}$} \\
\hline 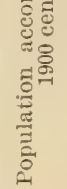 & 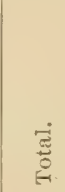 & 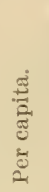 \\
\hline
\end{tabular}

Pennsylvania-Ctd

No.

Chester ......... 33,988

biston .......... $25,23 \mathrm{~s}$

Galls. Pints. Galls. Galls.

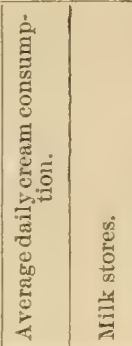

Juhnstown

3.5, 9330

Lancaster

41,459

MeKeesport

34,227

\begin{tabular}{l|l|l|l}
1,625 & 0.38 & 600
\end{tabular}.

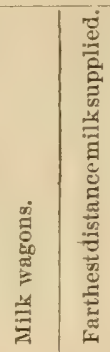

Production of

milk within

city limits.

Newcastle ...... 28,339

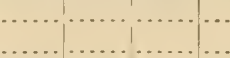

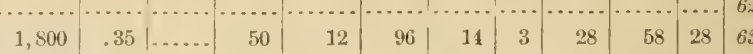

\begin{tabular}{l|r|l|l|l|l|l|l|l|l|l|l|}
2,000 & .47 & $\ldots \ldots$ & $\ldots \ldots$ & $\ldots \ldots$ & 50 & 5 & $\ldots$ & 15 & 30 & $\ldots$. & 64
\end{tabular}

\begin{tabular}{l|l|} 
Williamsport..... & 28,757
\end{tabular}

\begin{tabular}{l|l|l|l|}
700 & .20 & 150 & 150
\end{tabular}

\begin{tabular}{l|l|l|l}
75 & 7 & 0
\end{tabular}

\begin{tabular}{l|l|l|l|l|l|}
875 & .24 & $\ldots . .$. & $\ldots . .$. & 14 & 90
\end{tabular}

York

33,708

Rhode Island:

Pawtucket

Woonsocket $a$....

39,831

\begin{tabular}{l|l|l|l|}
1,350 & .32 & 150 & 25
\end{tabular}

$25 \quad 40$

Tennessee:

Chattanoogar....

Knoxville

'Texas:

Dallas.

Fort Worth $a$

Galveston $a$

Houston

28,204

\begin{tabular}{|c|c|c|}
\hline 2,955 & .60 & 75 \\
\hline
\end{tabular}

30,154

32,637

Virginia:

Norfolk $\alpha$.

Washington:

Spokane

Tacomate. .

West Virginia:

Wheeling .

Wisconsin:

La Crosse

Oshkosh .........

Racine.

Superior

\section{2,638}

26,688

37,789

5,250

$\begin{array}{lll}50 & 14\end{array}$

0

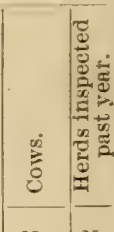


MILK SUPPLY OF TWO HUNDRED CIIIES.

cilies of over 25,000 and under 50,000 population (Class III).-Continued.

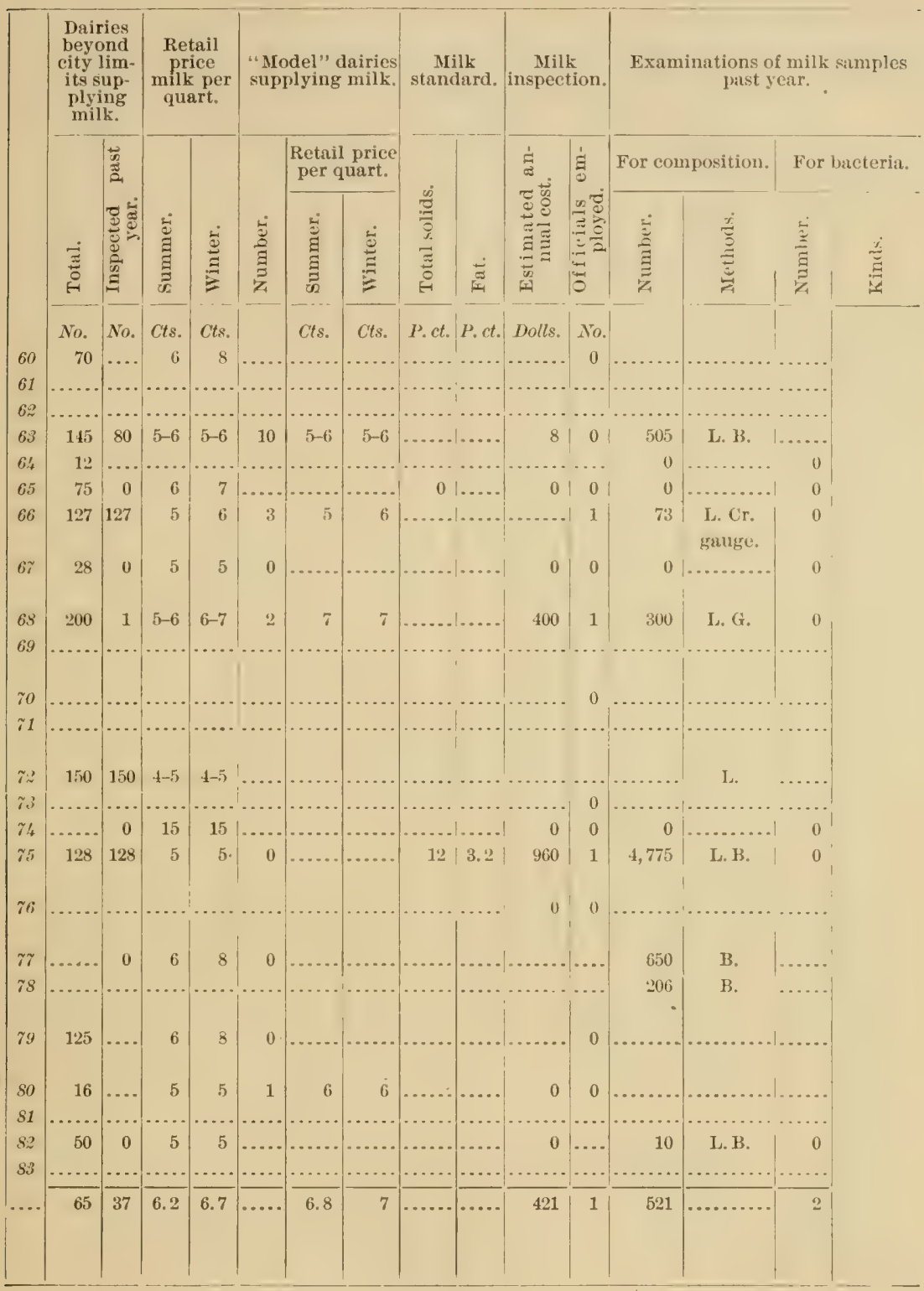


TABLE IV.-Statistics of milk supply and supervision in (39)

States and cities.

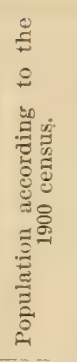

\section{California:}

Alameda.

San Jose ........

No.

16,464

21, 500

Colorado:

Colorado Springs.

Trinidad.

Illinois:

Aurora.......... 24,147

\begin{tabular}{l|l|} 
Evanston ........ 19,259 & 17,19
\end{tabular}

Ioline.

17,248

Ottawa

10,588

Indiana:

Richmond.

18,226

Iowa:

Burlington.......

Keokuk..........

Marshalltown....

Ottumwa ........

Iaine:

Belfast

Lewiston.

23,201

22,698

14,641

11,544

18,197

Waterville .......

4, 615

23,761

Massachusetts:

Melrose

North Adams .... 24. 24.200

North Attleboro... $\quad 7,253$

Wrakefield........ $\quad 9,290$

Woburn

14,254

Michigan:

Battleereek .......

Lansing...........

New Jersey:

IIontclair.

New Brunswick..

New York:

Lockport.

Mount Vernon...

Rome

Watertown

13,962

20,006

8,563

6,485

1,600

1,000

500

$800 \quad .55+100$

\begin{tabular}{l|l|l|l|}
606 & $f .27$ & 15 & 12 \\
\hline
\end{tabular}

300

1,800

800

800

2, 000

885

800

1,032

1,400

1,000

860

1,250

16,581

21,228

15,343

21,696
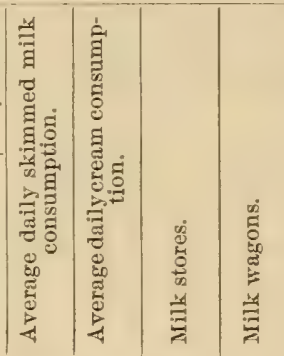

总|

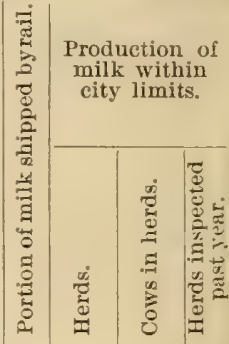

$a \mathrm{~S}=$ State control.

$b \mathrm{~L}=$ Lactometer. $\quad B=$ Babcock test. $\quad \mathrm{G}=$ Gravimetric analysis.

$c^{\top} \mathrm{T} u=$ Tubercle bacilli. Ty $=$ Typhoid bacillı. B'd corp. $=$ blood corpuscles.

"3,76 gallons brought to city daily, but about one-third goes to suburbs not included in the popu. lation of San Jose. 
cities and towns of less than 25,000 population (Class $I \mathrm{~V}$ ).

\begin{tabular}{|c|c|c|c|c|c|c|c|c|c|c|c|c|c|c|c|}
\hline & $\begin{array}{l}\text { Dai } \\
\text { beyo } \\
\text { city l } \\
\text { its } \\
\text { ply } \\
\text { mil }\end{array}$ & $\begin{array}{l}\text { ries } \\
\text { ond } \\
\text { lim- } \\
\text { up- } \\
\text { ing } \\
\text { ik. }\end{array}$ & $\begin{array}{r}\text { Re } \\
\text { pr } \\
\text { mil } \\
\text { qu }\end{array}$ & $\begin{array}{l}\text { tail } \\
\text { ice } \\
\text { k per } \\
\text { art. }\end{array}$ & $\begin{array}{l}\text { " Mro } \\
\text { supp }\end{array}$ & $\begin{array}{l}\text { del" } \\
\text { lying }\end{array}$ & $\begin{array}{l}\text { airies } \\
\text { milk. }\end{array}$ & $\begin{array}{l}\text { Mi } \\
\text { stane }\end{array}$ & $1 \mathrm{k}$ & $\begin{array}{r}\text { Mil } \\
\text { inspect }\end{array}$ & tion. & Exam & $\begin{array}{r}\text { nations o } \\
\text { past y }\end{array}$ & $\begin{array}{l}\text { milk } \\
\text { ar. }\end{array}$ & amples \\
\hline & & 蒡 & & & & $\begin{array}{r}\text { Retail } \\
\text { per q }\end{array}$ & $\begin{array}{l}\text { price } \\
\text { uart. }\end{array}$ & & & & & For con & position. & For & acteria. \\
\hline & हैं & 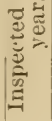 & 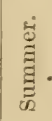 & $\stackrel{\stackrel{E}{S}}{\Xi}$ & $\frac{\stackrel{5}{\vdots}}{\grave{g}}$ & 苛 & 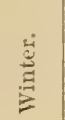 & $\begin{array}{l}\frac{0}{0} \\
\frac{1}{3} \\
\frac{5}{0} \\
\frac{5}{0}\end{array}$ & 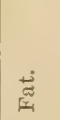 & 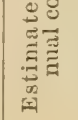 & 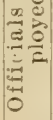 & $\frac{\dot{d}}{\mathrm{~d}}$ & 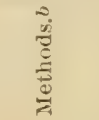 & 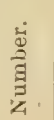 & 莕 \\
\hline & No. & No. & Cts. & $C t s$. & & Cts. & Cts. & P.ct. & P. ct. & Dolls. & No. & & & & \\
\hline 1 & 23 & 23 & 63 & $6 z$ & 5 & $7 \frac{1}{8}$ & $8 \frac{1}{3}$ & 12.5 & ..... & 1,200 & 1 & 925 & I. B. G. & 20 & Bd. corp. \\
\hline 2 & 127 & 127 & 5 & 5 & Few. & 5 & 5 & 13 & $3 \frac{1}{4}$ & 600 & 1 & ...... & B. & 0 & \\
\hline 3 & 17 & 8 & $\left\{\begin{array}{r}e \mathrm{I} \\
5-8 \frac{1}{3}\end{array}\right.$ & $\begin{array}{r}e \mathrm{P} \\
5-8 \frac{1}{3}\end{array}$ & 3 & $6 \frac{1}{4}$ & $6 \frac{1}{4}$ & 12 & 3 & & 1 & 175 & G. & 3 & Ту. Tu. \\
\hline 1 & .... & .... & $6 \frac{9}{3}$ & $6 \frac{2}{3}$ & 0 & & & 12 & 3 & & $\ldots$ & 8 & B. L. G. & 0 & \\
\hline 5 & 100 & 0 & 5 & 5 & 1 & 12 & 12 & 12 & 3 & 300 & 1 & 314 & B. L. & 15 & Tu. \\
\hline i & 37 & 25 & 6 & $7-10$ & 2 & 8 & 10 & 13 & 3 & ..... & 2 & 40 & B. I. G. & 0 & \\
\hline$\gamma$ & 30 & 24 & 5 & 5 & 0 & & & & & ..... & $\mid \ldots$. & 332 & B. & ..... & \\
\hline$S$ & 13 & 11 & 5 & 6 & 0 & & & & & 400 & 1 & 13 & B. $\mathrm{L}_{\text {. }}$ & 0 & \\
\hline$\because$ & 36 & 36 & 5 & 5 & Few. & 5 & 5 & & & 150 & 1 & 38 & B. & .... & \\
\hline . & 12 & 0 & 5 & 6 & 0 & & $\ldots$ & & & S. & ... & 600 & B. & 0 & \\
\hline : & 30 & $\ldots$ & 5 & 5 & 0 & & $\ldots$ & & & $\mathrm{s}$. & |... & 4,000 & B. & .... & \\
\hline $1:$ & ...... & $\cdots$ & 5 & $6 \frac{1}{4}$ & 0 & & & & & S. 126 & .... & 432 & B. & 0 & \\
\hline 1.) & 12 & .... & $4-5$ & $5-6$ & 0 & & ... & & & S. 110 & .... & 500 & B. & $\cdots$ & \\
\hline $1 ;:$ & 20 & 1 & 5 & 6 & 0 & & & & & S. & $\mid \ldots$. & 576 & B. & 1 & Ty. \\
\hline 1.5 & 30 & 130 & 5 & 6 & 0 & & & & & 50 & 1 & 150 & B. I. G. & 0 & \\
\hline $1 i ;$ & 50 & 10 & 6 & 6 & 0 & & .. & & & 200 & 1 & 300 & B. L. G. & 0 & \\
\hline $1 i$ & 39 & 39 & 5 & 6 & 4 & 5 & 6 & & & 100 & 1 & 160 & B. L. & 0 & \\
\hline $1 \mathrm{Y}$ & 25 & .... & $5-7$ & $5-7$ & 6 & 7 & 7 & & & 100 & 1 & 36 & L. G. & 0 & \\
\hline 1.1 & 75 & 75 & 5 & 6 & Few. & 5 & 6 & & & 100 & 2 & 300 & B. & 0 & \\
\hline (2) & 8 & $\ldots$ & 6 & 6 & 0 & ... & & & & 200 & 1 & 150 & B. & 0 & \\
\hline 21 & .... & .... & 6 & 6 & Few. & 7 & 7 & & - & 150 & ... & 154 & B. G. & 0 & \\
\hline 22 & & $\ldots$ & 6 & 6 & 0 & $\cdots$ & & & & 100 & $\ldots$. & 25 & L. $G$. & & \\
\hline$\therefore 3$ & 70 & 70 & 5 & 5 & & & & 12.5 & 3 & 130 & 1 & 560 & B. L. & & \\
\hline 23 & 45 & 45 & 5 & 5 & & & & & & 900 & 1 & 41 & B. L. & 4 & Tu. \\
\hline 25 & 24 & 24 & $7-12$ & $7-12$ & 6 & $8-12$ & $8-12$ & & & 300 & 2 & 166 & B. L. G. & 166 & \\
\hline$\therefore i$ & 55 & |... & $4-6$ & $5-8$ & 1 & 6 & 8 & & & S. & $\ldots$ & 3,500 & B. & ..... & \\
\hline$\because 2$ & 22 & 12 & 5 & 6 & 0 & & & & & s. & & $\left\{\begin{array}{r}40 \\
1,000\end{array}\right.$ & $\begin{array}{l}\text { B. } \\
\text { L. }\end{array}$ & 0 & \\
\hline 28 & 90 & 90 & $7-15$ & $8-15$ & 4 & $8-15$ & $8-15$ & 12 & 3 & 500 & .... & 40 & L. B. G. & 275 & Ty. \\
\hline 29 & 36 & 36 & 4 & 5 & 0 & & & & & 400 & 1 & 106 & L. B. & ..... & \\
\hline 30 & 37 & 37 & 5 & 5 & ..... & $1 . . . .$. & . & 1...... & I..... & 750 & 12 | & 850 & L. B. G. & 0 & \\
\hline
\end{tabular}

$e$ Pasteurized.

$f$ Large number of people keep private cows, and some sell milk to neighbors. $g$ There are also about 200 cows kept by private families.

$h$ Large amount used in institutions, population of which is not counted in the city. 
TABLE IV.-Statistics of milk supply and supervision in (39)

\begin{tabular}{|c|c|c|c|c|c|c|c|c|c|c|c|c|c|}
\hline \multirow[b]{2}{*}{ States and cities. } & \multirow{2}{*}{ 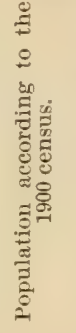 } & \multicolumn{2}{|c|}{$\begin{array}{c}\text { Average } \\
\text { daily milk } \\
\text { consumption. }\end{array}$} & \multirow{2}{*}{ 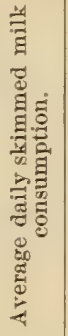 } & \multirow{2}{*}{ 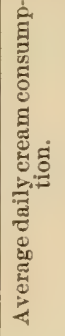 } & \multirow[b]{2}{*}{ 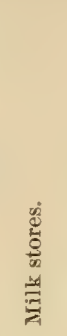 } & \multirow[b]{2}{*}{ 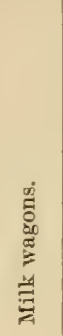 } & \multirow{2}{*}{ 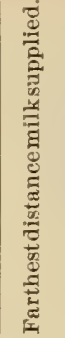 } & \multirow{2}{*}{ 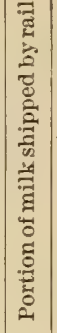 } & \multicolumn{3}{|c|}{$\begin{array}{l}\text { Production of } \\
\text { milk within } \\
\text { city limits. }\end{array}$} & \\
\hline & & 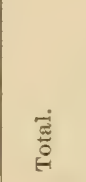 & 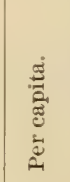 & & & & & & & 苞 & 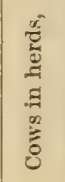 & 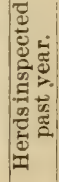 & \\
\hline $\begin{array}{l}\text { Ohio: } \\
\text { Fostoria... }\end{array}$ & $\begin{array}{l}\text { No } \\
7,730\end{array}$ & $\begin{array}{r}\text { Galls. } \\
400\end{array}$ & $\begin{array}{r}\text { Pints. } \\
.41\end{array}$ & $\begin{array}{r}\text { Galls. } \\
25\end{array}$ & $\begin{array}{r}\text { Galls. } \\
10\end{array}$ & $\begin{array}{l}\text { No. } \\
10\end{array}$ & No. & $\begin{array}{c}\text { Miles. } \\
3\end{array}$ & $\left|\begin{array}{l}P . c t \\
\ldots . .\end{array}\right|$ & No. & $\begin{array}{l}\text { No. } \\
125\end{array}$ & $\left|\begin{array}{c}\text { No } \\
1\end{array}\right|$ & 31 \\
\hline Hamilton .. & 23,914 & 1,027 & .31 & & & 46 & 32 & 6 & 0 & 21 & 73 & 13 & 32 \\
\hline Warren .... & 8,529 & 645 & .60 & 20 & 20 & 1 & 11 & 15 & 3 & 1 & 24 & 1 & 33 \\
\hline Pennsylvania: & & & & & & & & & & & & & \\
\hline Lebanon .... & 17,628 & 1,500 & .68 & 200 & 300 & ... & 45 & 8 & 0 & 15 & 60 & 12 & 34 \\
\hline Meadville.... & 10,291 & 875 & .68 & & .... & 2 & 30 & 4 & & & 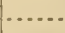 & .. & 35 \\
\hline Phoenixville.. & 9,196 & 725 & .63 & 30 & 10 & 3 & 37 & 5 & ... & 7 & 60 & ... & 36 \\
\hline Wisconsin: & & & & & & & & & & & & & \\
\hline Green Bay .. & 18,684 & 600 & $a .26$ & & 60 & 1 & 28 & 8 & 0 & 8 & 120 & 8 & 37 \\
\hline Marinette... & 16,195 & 464 & $\mid a, 23$ & $\cdots$ & 12 & 3 & 23 & 96 & 10 & 8 & b 105 & 8 & $3 s$ \\
\hline Waukesha ...... & 7,419 & 395 & | . .43 & 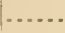 & 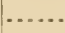 & ........ & 15 & 3 & 0 & 2 & 40 & ... & 39 \\
\hline $\begin{array}{l}\text { Average of } \\
\text { those re- } \\
\text { porting. }\end{array}$ & 15,728 & 1,112 & .57 & 109 & 68 & 15 & 34 & 25 & 6 & 12 & 136 & 11 & 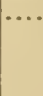 \\
\hline
\end{tabular}

a Large number of people keep private cows, and some sell milk to neighbors. 
cilies and toms of less than 25,000 population (Class $I \mathrm{~V}$ )-Continued.

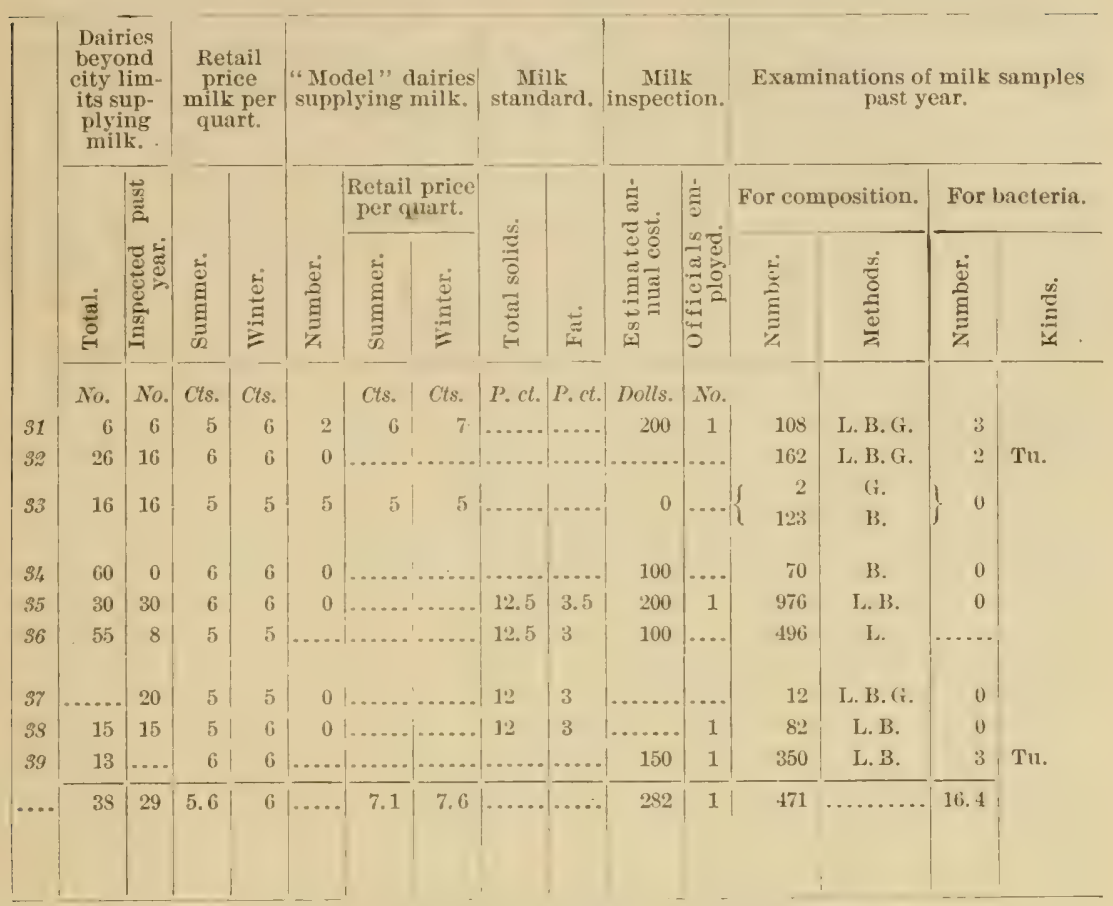

b There are also about $200 \mathrm{cow}$ kept by private families. 
TABLE V.-State standards for milk, skimmed milk, and cream.

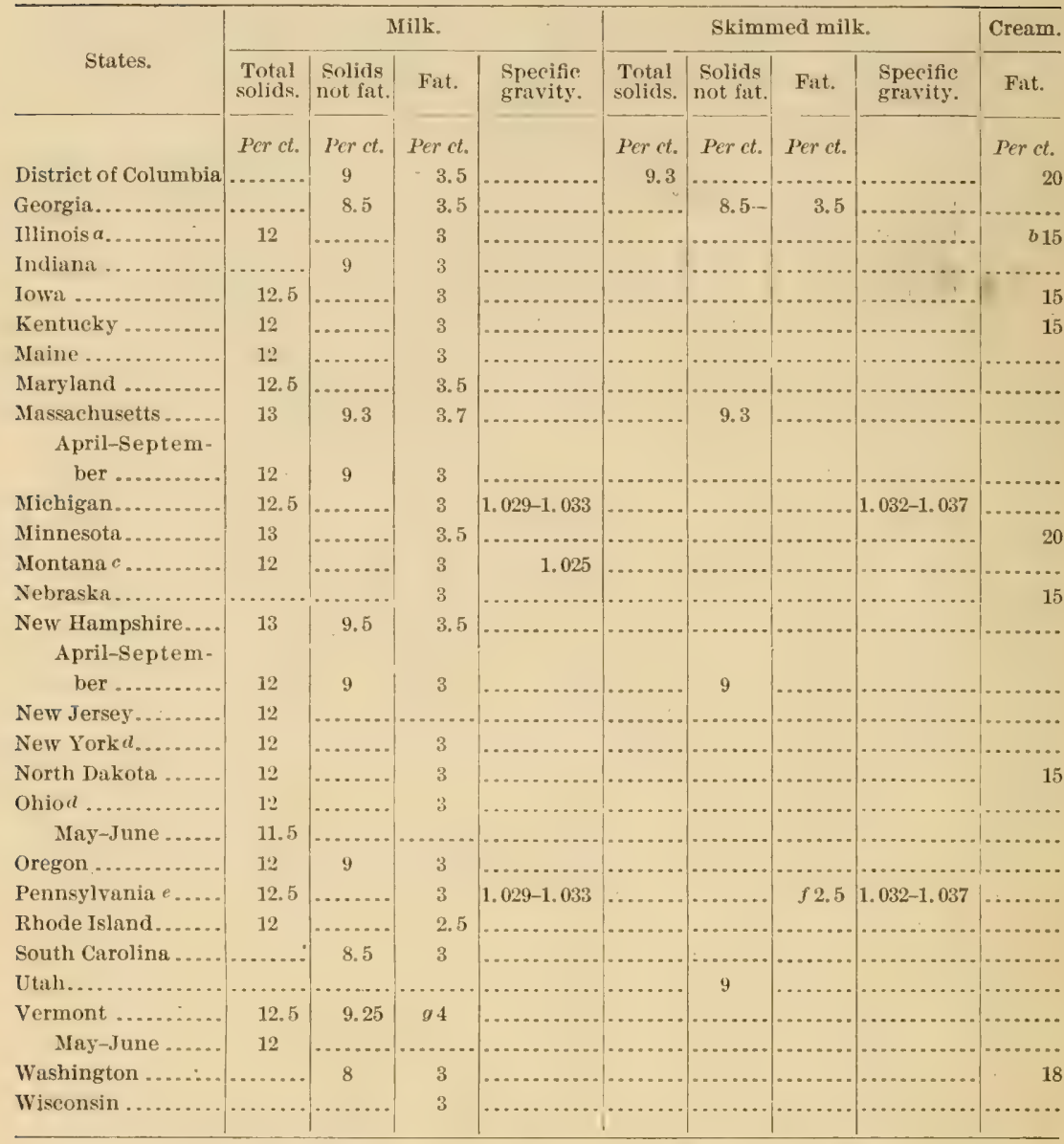

a Condensed milk shall be made from milk containing at least the legal standard of 3 per cent butter fat and evaporated to one-third or less of its original volume.

$b$ Coffee cream shall contain at least 15 per cent of fat, and whipping cream 22 per cent fat.

c Applies to cities with a population over 5,000 .

dIn New York and Ohio the milk solids of condensed milk shall be in quantity the equivalent of 12 per cent of milk solids in crude milk, of which solids 25 per cent shall be fat.

$e$ Milk and skimmed milk standards refer to eities of second and third class.

$f$ Six per cent cream by volume.

$g$ As basis for pryment at factories.

\section{SHORT STATEMENTS REGARDING THE MLK SLPPLY OF CITIES AND TOWNS.}

In the following pages are given briefly and in narrative form such statistical and other general information as it has been possible to collect in the course of this inquiry regarding the milk supply of every one of the 161 cities in the United States having a population of over 25,000, 
according to the census for 1900, and of 39 others selected from the large number of smaller cities and towns. The data thus given show, therefore, the conditions as reported by 200 representative cities and towns in the United States.

The cities and towns of each State are grouped together in the order of their size; and those in each group are preceded by a general account for the entire State whenever there are facts of interest which apply to the State as a whole. This latter includes an abstract of State laws relating to milk, and a few words to show what has been done under these laws by the State authorities.

The statement for each city and town includes the following information, or so much of it as has been obtainable: First, the name and title of the official most closely connected with the supervision of the milk supply; second, general statistics - the amount of milk used, the way it is handled, the prices for which the producers and retailers sell it, and the number and location of herds supplying it; third, an abstract of the local ordinances, regulations, etc., relating to the milk supply (care has been taken to give in considerable detail the requirements of the milk ordinances in all cities of Class I, but in others many of the ordinary requirements are omitted or barely referred to); fourth, a summary of the work done by the authorities in the supervision of the milk supply - the amount of money expended for this purpose, the number of officials employed, and numbers of inspections of dairies, and chemical and bacteriological examinations of milk; fifth, mention of a few ways in which recent improvement of the milk supply has been shown, if at all, and suggestions for further improvement; and, sixth, additional matter of interest, whenever supplied, such as the results of special investigations. With very few exceptions, every statement is based wholly upon reports received from the official named in connection with it.

\section{ALABAMA.}

This State has no milk law.

Mobile. (Population, 38,469.)

[For comparison with other cities in Class III, see p. 34.]

D. T. Rogers, clerk of the board of health.

Milk is sold from 8 stores and 35 wagons. A portion of the milk is delivered in glass bottles, which are filled at the farms. The retail price is 10 cents per quart throughout the year. There are no "model dairies" near the city. Milk is supplied from 35 dairy farms, all within a radius of 6 miles.

The city has no milk ordinance and exercises no supervision over its milk supply.

Birmingham. (Population, 38,415.)

[For comparison with other cities in Class III, see p. 34.]

W. B. Fleming, chief inspector of meat and milk.

The estimated daily consumption of milk is 2,000 gallons, or an average of 0.42 pint per capita. Milk is sold from 2 stores and 100 wagons. About 50 per cent of 
the milk is delivered in glass bottles, which are 11stally filled at the farms. The retail price of milk is 8 cents per quart in summer and 9 cents in winter. The milk from 2 "model dairies" is sold for 9 cents per yuart in smmer and 10 cents in winter. Within the city limits there are 20 herds, including 300 cows, and milk is sent in from 90 dairy farms. About 10 per cent is received by railway, the longest shipment being 50 miles.

An ordinance adopted in September, 1899, regulates the sale of milk in the city. License for supplying milk is as follows: For 10 or fewer cows, $\$ 5$; over 10 cows, $\$ 10$; but private families keeping not more than 2 cows may sell the surplus milk to their neighbors without licenses. Adulterater, etc., milk is prohibiter. Cows producing milk for the city must be tested with tubereulin. The milk standard is 12.5 per ('ent solids, 3 per cent fat, and a specific: gravity at $60^{\circ} \mathrm{F}$. between 1.029 and 1.033 . Skimmed milk must contain 9 per cent milk solids not fat.

One thousand dollars is expended annually in the supervision of the city milk supply, one milke inspector giving his entire time to this work. In the past three months 500 samples were examined hy lactometer, Bahcock test, and gravimetric analysis; all the city herds and 40 of the 90 dairy farms were inspected.

The inspector states that better sanitary conditions should obtain at dairies, and more care should be exercised in feeding milch cows.

\section{Montgomery. (Population, 30,346.)}

[For comparison with other cities in Class III, see p. 31.]

\section{W. L. Stewart, milk inspector.}

John L. Harley, clerk of the sanitary department.

The amount of milk sol: 1 daily is estimaterl as 540 yallons, or 0.14 pint per capita, hesides 20 gallons of skimmed milk and 25 gallons of cream. In explanation of this low consumption of milk, it is stated that nearly half of the families in the city keep their own cows and sell milk. This milk is not included in the above estimate. Milk is sold from no stores, but from 25 wagons. Only a limiterl quantity of milk is delivered in glass bottles, and these are filled at the farms. None is pasteurized. The retail price of milk is 10 cents per quart throughout the year, the producers selling direct to the consumers. No dairy near the city is conducted in an entirely satisfactory manner. Jilk is supplied from one herd of $1+$ cows within the eity limits, and 19 herds ( 537 cows) on farms within a radius of 8 miles.

Milk ordinances adopterl in September, 1896 , regulate the sale of milk. All persons selling or supplying milk must take out an ammal license, at the rate of $\$ 5$ for 10 cows or under, and $\$ 10$ for any number exceeding 10 cows, lut persons who keep not more than 2 cows for family use and sell the surplus milk to neighbors are exempt from license. Arlulteraterl, ete., milk is prohibited. Cows prorlucing milk to be used in the city must be free from dangerous divease, and must be tested with tuberculin. The milk standard is 12.5 per cent solids, 3 per cent fat, and specific gravity at $60^{\circ} \mathrm{F}$, between 1.029 and 1.033 . Skimmerl milk standard is 9 per cent milk solids not fat.

One thousand dollars is expenderl annually in the supervision of the milk supply. A milk chemist and inspector gives lis entire time to this work. During the past year 864 samples of milk were examinell hy lactoneter, Bahook test, and gravimetric analysis, besides tests for coloring matter and preservatives; several examinations were made for tubercle hacilli. The cows at 17 dairy farms were tested with tuber('ulin, and all dairies were examiner one a month as to sanitation, food, manner of handling milk, etc.

Recently there has been an improvement in the rharacter of the milk supply and in the sanitary endition of daries. It is helieverl that more sanitary dairy huildings are needed. 


\section{ARIZONA.}

This Territory has no milk law.

\section{ARKANSAS.}

This State has no milk law.

Little Rock. (Population, 38,307.)

[For comparison with other cities in Class III, see p. 34.]

R. B. Christian, secretary of the State board of health.

The amount of milk sold daily is about 1,300 gallons, or 0.26 pint per capita. In explanation of this small consumption of milk, it is stated that a large proportion of the city families keep their own milch cows, whose product is not included in the above figures. Milk is sold from a few stores and about 40 wagons. Within the (ity there are 25 herds, including 250 cows, and milk is sent in from 40 dairy farms, the most distant being 12 miles from the city.

The city has no milk ordinance and exercises no supervision over its milk supply.

\section{CALIFORNIA.}

J. MT. Thomas, agent and secretary of the State dairy bureau, San Francisco.

Statutes of 1899 - chapter 136 refers to milk. No person shall sell impure milk or eream, or milk that is from cows fifteen days before or five days after parturition, or milk from cows that are diseased or fed unwholesome food. It is the duty of the State dairy bureau to inspect any dairy complained of as having diseased cows or being in an insanitary condition, and the bureau may require changes at places inspected. The State veterinarian may order the slaughter of diseased animals at the expense of owners. County district attorneys shall prosecute offenders.

Statutes and amendments to the Codes, extra sescion, 1900-1901, page 324: The use of incorrect glassware, Babcock testers, etc, in determining the richness of milk or cream as a basis for payment therefor is prohibited.

The State exercises no supervision over the milk supply of cities.

San Francisco. (Population, 342, 782.)

[For comparison with other cities in Class I; see P. 26.]

Adolph Sutro, president of the board of health.

The daily consumption of milk is estimated as 25,000 gallons, or 0.58 pint per capita. It is estimated, also, that the city consumes daily 500 gallons of skimmed milk and 1,500 gallons of cream. Milk is sold from 173 stores and 350 wagons. Glass bottles are used by large dealers in the delivery of about one-fourth of the total milk supply; they are filled in the city. Practically no pastenrized milk is used. The retail price of milk is 5 to 7 cents per quart throughont the year, the producers receiving 2 to 3 cents. There are no dairies near the city which could be classed as "model dairies." Within the city there are 196 herds, including 5,880 cows, and milk is sent into the city from 300 dairy farms, the longest shipment being 60 miles.

The milk ordinance of January, 1896, gives authority to the board of health to regulate the milk supply. Some of the principal requirements of the ordinance and regulations are as follows: Each person selling milk in the city must have a permit. This is issued without cost by the board of health only after certain detailed information regarding the source of the milk and the conduct of the proposed business has been filed; it is revocable for cause. A permit is required for every place where milk is sold. Each person holding a permit must file at least once a year a detailed statement containing data similar to that in the application. Permit number shall 
be prominently displayed wherever milk is sold. The ordinance forbids the sale of impure, ete, milk, including milk from cows fifteen days before or five days after calving; milk from cows given unwholesome food or water, or kept in insanitary condition, or affected with disease; milk to which any water or other substance has been added, or from which any cream has been removed; milk that is drawn from cows or by milkers that are unclean; and milk containing less than 12 per cent solids, or 3.2 per cent fat. Swill, garbage, or milk diluent must not be carried in delivery wagons. The hoard of health must occasionally have inspecter all rlairies from which milk is brought into the city. Owners of dairies must report conditions which might render milk impure. The sale of condensed milk, buttermilk, or sour milk is permitted if from pure milk; the proportion of solids in condensed milk must be equivalent to 12 per cent solirls in crude $m i l k$ and 26.5 per cent of them nust be fat. Market inspectors are required to visit, twice a month, all dairies in the city and county and they are requester to visit nilk ranches at least once a month. In certain parts of the city no person may keep more than 2 cows.

The ordinance section concerning carrying swill on milk-delivery vehicles is given in Appendix I (p. 180).

The city makes no special appropriation for the supervision of its milk supply, nor is any officer designated to give his entire time to this work. During the past year 464 samples of milk were examined for specifie gravity and fat by lactometer and Babcock test, checks being oceasionally made by the Westphal balance, butyrorefractometer, and gravimetric analysis; 3 samples were examined bacteriologically2 for tubercle and 1 for typhoid bacilli; none of the city dairies or dairy farms sending milk to the city have been inspected.

It is not stated that the milk supply has recently shown any marked improvement. Liberality in providing funds for the health department to carry on a thorough inspection of dairies is recommended. It is also urged that milk users be more particular as to the character of the milk delivered to them.

Los Angeles. (Population, 102,479.)

[For comparison with other cities in Class I, see p. 26.]

George W. Hood, milk inspector.

The amount of milk sold daily is estimatert as 4,500 gallons, or 0.35 pint per capita, besides 150 gallons of cream and a very small amomnt of skimmed milk. These figures do not include the milk producesl hy town cows and not sold, hence the average daily consumption is greater than 0.35 jint per capita. Milk is sold in nearly all grocery stores and in many of the fruit stores, and is served from 112 wagons. Glass bottles are used largely in the delivery of milk, being filled only at the dairies. It is estimated that about 1,000 gallons of $n$ ill is pastemrizerl daily, the pratetice having increased since the use of formalin was stopped. The retail price of milk is 5 cents per quart, both summer and winter, and the price paid the producer is just half that amount. There is only one "model dairy," which receives $7 \frac{1}{2}$ cents per quart throughout the year for its product. Within the rity limits there are 25 dairy herds, including about 500 head. Milk is sent into the city from 2,000 cows, on about 75 dairy farms. About 5 per cent of the milk supply is received by rail, the longest shipment being 20 miles.

City milk ordinance (No. 6t92), adopted in March, 1901, requires all milk or cream dealers to have an annual permit, granted by the board of health free of charge. Dairies, cows, cow stahles, milk houses, milk vesels, and vehicles, whether within the city limits or not, must be subject to inspection by a board of health officer. Milk must be redueed to $60^{\circ} \mathrm{F}$. before it is put into closed cams or marketed, and delivery wagons must be covered during the months of May to Séptember. Bottling must be done at the milk houses and not upon the delivery wasons. The 
delivery of bottled milk to any dwelling where there is a contagions disease is prohibited. The milk standard is as follows: Specific gravity, 1.03 ; butter fat, 3.4 per cent; total solids, 12 per cent; cream by volume, 9 per cent. Cream standard, butter fat 20 per cent. Skimmed milk may he sold if plainly labeled. Milk is prohibited from cows fed on any garbage or other improper food, or kept in an unsanitary condition.

In 1899 a resolution was adopted by the hoard of health prohibiting the delivery of milk in bottles. This resolution was passed because of the practice of refilling the glass jars in delivery wagons or elsewhere, without having the jars properly cleansed, thereby making it possible for contagions diseases to he conveyed and milk to be otherwise contaminaterl. The length of tine this rule was in effect is not given.

The annual expenditure for the supervision of the city milk supply is alout $\$ 1,100$, one inspector giving his entire time to this work. During the year 419 samples of milk were examined by lactometer and the Babcock test; a part of them also for formalin. All dairy farms and all cows from which milk is userd have been inspecterl. A detailed statement of the work performed by the milk inspector in the year ending November 30,1899 , is as follows:

Inspections of dairies, ranches, and milk depots........... 1, 782

Samples of milk tested............................. 765

Cows condemned (tubereulosis) ............................... 6

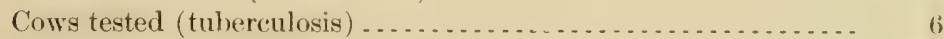

Complaints sworn to ...................................... 10

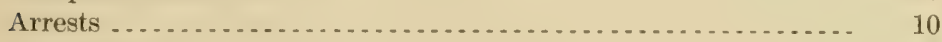

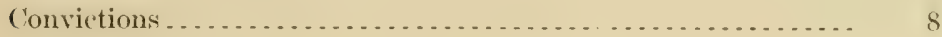

Acquittals ................................................. 1

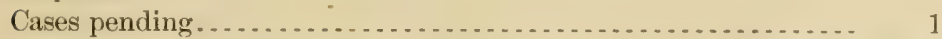

The general average percentage of hutter fat in samples tested this year was 3.6. Samples from hotels and restaurants averaged only 2.8, while those from dairy wagons averaged 3.7 .

The form for dairyman's permit to sell milk, and stuh, for same, is shown in Appendix IV (p. 201).

Recent improvements in the quality of milk are due to the recreased use of preservatives and a better sanitary condition of the dairy premises. A more thorough inspection of the cattle, dairies, and milk, and a more rigid enforcenent of the ordinances, would bring about further improvement.

\section{Oakland. (Population, 66,960.)}

[For comparison with other eities in Class II, see p. 30.]

Fred.E. Pierce, D. V. S., market, meat, and milk inspector.

The daily consumption of milk is estimated as 4,500 gallons, or 0.54 pint per capita, besides about 100 gallons of skimmed milk and to gallons of cream. Milk is sold from th stores and 80 wagons. Glass bottles, filled in the city depots, are used in the delivery of only a very small portion of the milk supply. The practice of prasteurizing milk has been discontinued. The retail price of milk varies during the year from 5 cents to 10 cents per quart, producers receiving 3 to 313 cents throughout the year. About 3,500 cows, in 45 city herds and 35 country herds, furnish the city with milk. A very small portion of the milk supply is receiverl by railway, the longest shipment being 40 miles.

Ordinance No. 1618, July, 1894, refers to milk. Persons selling milk must be registered. Impure, adulterated, ete, milk is prohibited. The milk standard is 3 per cent fat. Skimmed milk must be labeled.

$25839-$ No. $46-03-4$ 
About $\$ 1,200$ is expended ammally in the supervision of the milk supply, one inspector giving the greater part of his time to this work. During the past year 250 samples of milk were examiner by the Babcock test, 10 samples were examined bacteriologically, and all the city herds and all the dairy farms were inspected.

Recent improvement has heen made in the sanitary condition of the dairies. The rnatenent and enforcement of measures to require cleanliness in the production of milk is given as an important need.

Sacramento. (Population, 29,282.)

[For comparison with other cities in Class III, see p. 34.]

H. L. Nichols, M. D., health officer.

The daily consmption of milk is estimated as 3,000 gallons, or 0.82 pint per eapita, hesides 50 gallons of cream. Milk is sold from 15 stores and 55 wagons. Glass bottles are used to a small extent (mostly for cream), and they are filled both in the city and at the farms. Very little milk is pasteurized, and the practice is not increasing. The retail price of milk is 7 cents per quart throughout the year. There are no dairy herds within the city limits, hut about 100 cows are kept by private familiew. Milk is brought to the city in wagons from 36 dairy farms, the longest haul being 7 miles.

City ordinance No. 428 and board of health ordinances Nos. 48 and 49 refer to milk. Permits for the sale of milk are issued free of charge. The sale of impure, ardulteraterl, ete, milk is prohil,ited. The milk standard is 12 per cent solids, 3 per cent fat. Dairies supplying milk to the city must be kept clean, and all utensils used in handling milk must be sterilized with boiling water once a day. Garbage, ete., must not be arrierl in milk wagons. (ondensed milk and buttermilk must be from pure milk. ('molensod milk must have milk solids equivalent to 12 per cent milk solids in crude milk; 26.5 per cent of the milk solids must be fat.

Alont 81,300 is expenderl annually in the supervision of the eity milk supply, one insector giving his cntire time to this work. During the past year 1,200 samples of milk were examined hy the Babock test, and all the dairy farms were inspected.

San José. (Population, 21,500.)

[For comparison with other cities in Class IV, see p. 40.]

Robert Caldwell, M. D., secretary and health officer.

The daily consumption of milk is estimaterl as 2,512 gallons, or 0.93 pint per capita, hesider small amounts of skimmed milk and cream. Milk is sold from 40 stores and 100 wagons. Glass bottles, filled at the farms, are in general use in the delivery of milk. The retail price is 5 cents per quart throughout the year, producers receiving 3 cents in the summer and $3 \frac{1}{2}$ cents in the winter season. There are a few dairies near the city conducted on a more modern plan than others, but they receive no advance in price for their product. Within the city limits there are 3 herds, innluding to cows, and milk is brought in wagons from 127 dairy farms, all within 7 miles of the city.

Ordinances Nos. 1650 and 1654 refer to milk. License for the sale of milk is free. Adulterated, impure, etc., milk is prohibited. The milk standard is 13 per cent solids, one-fourth of which shall be butter fat. Skimmed milk must be labeled. Wagons must bear license number. The board of health has passed a regulation requiring that all cows furnishing milk for the city be tested with tuberculin.

Six hundred dollars is expended annually in the supervision of the milk supply, the milk and market inspector giving a part of his time to this work. During the past year milk samples were examined by the Babcock test. No bacteriological cxaninations were made. All the city herds and all the dair farms were inspected. 
Recent improvement in the milk supply is due to greater cleanliness at the dairies and a veterinary inspection of cows. It is stated that there would be further improvement if a State board of reterinary inspectors should examine all cows and kill those found to be affected with tuberculosis.

Alameda. (Population, 16,464.)

[For comparison with other cities in Class IV, see p. 40.]

T. Carpenter, V. S., veterinary and food inspector.

The daily consumption of milk is estimated as 1,760 gallons, or 0.86 pint per capita, besides 50 gallons of skimmed milk and 100 gallons of cream. Milk is sold from 21 stores and 38 wagons, and about 30 per cent of it is delivered in glass bottles, which are filled in the city. Several consumers pasteurize their own supply. The retail price of milk is $6_{4}^{3}$ cents per quart throughout the year, producers receiving 3 cents in summer and $3 \frac{1}{4}$ cents in winter. The milk from 5 "model dairies" near the city is sold for $7 \frac{1}{2}$ cents per quart in summer and $8_{3}^{\frac{1}{3}}$ cents in winter. There are 11 herds, including 62 cows, within the city limits, and milk is sent in from 2'3 dairy farms. About 9 per cent is received by railway, the longest shipment being 45 miles.

Ordinances No. 318, June, 1896, and No. 368, Octoher, 1898, and bourd of health regulations govern the milk supply. Permit is required for the sale of milk or cream. Impure or adulterater milk, or milk from cows within fifteen days before or ten days after calving, is prohibited. The milk standard is 12.5 per cent solids. Skimmed milk must contain 7.5 per cent milk solids and be plainly labeled. Cows must be free from dangerous disease and must not be fed upon wet brewers' grains, swill, etc., nor kept in an insanitary condition. Contagious disease among employees must be reported. Wagons must bear owner's name, etc.

Board of health rules and regulations for the handling of milk include a number of those published in the Seventeenth Annual Report of the Bureau of Animal Industry, pages 165-171. They are published on large cloth-backed cards, suitable for posting in stables, etc.

Twelve hundred dollars is expended annually in the supervision of the milk supply, one official giving his entire time to this work. During the past year 9.5 samples of milk were examined by lactometer, Babcock test, and gravimetri. analysis; 20 bacteriological examinations were made "for milk ferments, bloor corpuseles, etc.;" all the city herds and all the dairy farms were inspected.

Recently there has been an improvement in the health of the cows and in the sanitary method of handling milk. Needed improvements, as given, include the stamping out of tuberculosis and regulations to control dairy herds and the transportation of milk.

\section{COLORADO.}

This State has no milk law.

\section{Denver. (Population, 133,859. ${ }^{1}$ )}

[For comparison with other cities in Class I, see p. 26.]

Charles K. Cook, milk inspector.

S. B. Newland, deputy State dairy commissioner.

The daily consumption of milk is estimated as 12,110 gallons, or 0.65 pint per capita. It is also estimated that the city consumes daily about 1,000 gallons of skimmed milk and 2,000 gallons of cream. Milk is sold from only 200 stores, the greater part of it being distributed from 300 wagons, many delivering twice a day. Ahout 25

${ }^{1}$ Including average transient population, 150,000 . 
per cent is delivered in glass jars, which are filled in the city or on the dairy farms. The entire product of one establishment, amounting to 4 per cent of the total milk supply, is pasteurized. The retail price of milk is 5 to $6 \frac{1}{4}$ cents per quart in summer and $6 \frac{1}{4}$ to $8 \frac{1}{3}$ cents in winter, the producers receiving $2 \frac{1}{2}$ to 3 cents per quart throughout the year. Within the city limits there are 80 herds of 3 or more cows each, including 900 head, and about 1,500 separate or private cows. About 300 dairy farms send milk into the city. Of the total supply, about 10 per cent is received hy rail, the longest shipment being 150 miles.

Numerous milk regulations were publisher in the manual of the bureau of health in 1899. They are generally drawn up in considerable detail for the protection of milk consumers against the use of impure or arlulterated milk, or milk prodnced in insanitary places or from cows suffering from tuberculosis or other disease. The sale of milk from cows two weeks before or two weeks after calving is prohibited. The milk standard is 12 per cent total solids, 3 per cent fat; the cream standard, 25 per cent total solids, two-thirds of which shall be butter fat. Skimmed or watered milk may be sold to any person for his own individual consumption, if he is informed of the character of the article. When milk below the legal standard is used in hotels, restaurants, ete., a sign must be displayed bearing the words "watered milk." License (fee $\$ 1$ for one year) is required for each store or vehicle selling milk. A set of 10 rules relating to the production of milk-cleanliness and rentilation of stables, cleanliness of employees, straining of milk twice, cooling of milk and use of ice during its delivery in warm weather, use of screens to exclude flies from milk rooms, prohibition of preservatives-are printerl on cloth by the health commissioner to be posted in dairy stables.

Ordinance section regarding notice of use of watered milk is given in Appendix I (p. 180).

The city expends anmually $\$ 1,200$ for the supervision of the milk supply. (me milk and dairy inspector devotes his entire time to this work, and he is occasionaily assisted by the city chemist. During Nay, Jume, July, and August 1,200 samples of milk and 1,000 samples of cream were examined by the Babcock test, 600 samples were analyzed gravimetrically, and a few samples of milk were examined hacteriologically. All of the milch cows within the city limits and all the dairy herds outside which send milk to the city have been inspected.

\section{Pueblo. (Population, 28,157.)}

[For comparison with other cities in Class III, see p. 34.]

H. R. Thompson, milk and dairy inspector.

The daily consumption of milk is estimated as 5,000 gallons, or 1.42 pints per capita; also 350 gallons of skimmed milk and 200 gallons of cream. Milk is sold from 10 stores and 40 wagons. Thirty-three per cent of the milk is delivered in glass bottles, which are filled at the farms; none is pasteurized. The retail price of milk is 6 cents per quart in summer and 7 cents in winter. Within the city limits there are 20 herds, including 650 cows, and milk is sent in from 17 (?) dairy farms. Ten per cent of the crean is received by railway, the longest shipment being 20 miles.

The city expends annually about $\$ 1,000$ in the supervision of its milk supply, one dairy and milk inspector giving his entire time to this work. In the past nine months 344 samples of milk were examined by the lactometer, Babcock test, and by chemical tests for preservatives; no bacteriological examinations were made; all the city herds and all the country farms were inspected, 15 of the city herds being tested with tuberculin.

Recently there have been a higher fat content and a marked decrease in the use of preservatives. Needed improvements, as given, include better methods for cooling and aerating milk, sterilizing cans, and better sanitary conditions at the dairies. 


\section{Colorado Springs. (Population, 21,085.)}

[For comparison with other cities in Class IV, see p. 40.]

\section{R. H. Custer, food inspector.}

The daily consumption of milk is estimated as 1,800 gallons, or 0.68 pint per capita, besides 300 gallons of skimmed milk and 80 gallons of cream. This does not include the milk from about 200 cows kept by private families. Milk is sold from 19 stores and 28 wagons. None of the milk is shipped in glass bottles, but nearly all dairies use them and charge a higher price for the bottled product. Pasteurized milk is used by invalids, and at present many private lamilies do their own pasteurizing. The retail price of milk is 5 cents per quart throughout the year, bottled milk $6 \frac{1}{4}$ cents, and pasteurized milk $8 \frac{1}{3}$ cents, producers receiving 3 cents to $3 \frac{1}{2}$ cents per quart. The milk from 3 "model dairies" is sold for 61 cents. Within the city there is 1 herd (60 (ows), and milk is sent in from 17 dairy farms. The longest shipment of milk to the city is 14 miles.

An orlinance arlopted in December, 1897, refers to milk. License fees for the sale of milk or eream are $\$ 5$ for each wagon and store; $\$ 5$ for each shipper who does not sent to a licensed dealer; but persons who keep not more than 2 cows, and stores which sell milk or cream from a regular registered dairyman, pay only $\$ 1$. Impure, adulterated, ete., milk is prohibited, except that skimmed or watered milk may be sold if the buyer is informed of its character. "Watered milk" sign must be displayed in restaurants, etc., where milk is server that contains less than 3 per cent fat. The milk standard is 12 per cent solids, 3 per cent fat. Cream standard is 25 per cent solids, 16 per cent fat. Those handling milk must not he suffering from or exposed to contagious disease.

The food inspector (salary $\$ 1,020$ ) gives a part of his time to the supervision of the milk supply. During the past year 175 samples of cream were analyzed gravimetrically; 3 samples were examined bacteriologically for typhus and tubercle bacilli; and 8 (of the 18) dairy herds were inspected.

\section{Trinidad. (Population, 5,345.)}

[For comparison with other cities in Class IV, see p. 40.]

D. F. Dayton, health officer.

The daily consumption of milk is estimated as 500 gallons, or 0.75 pint per capita. Milk is sold from 10 wagons, but no stores, and about two-thirds of it is delivered in glass bottles, which are filled at the farms. Dairies do not supply pasteurized milk. The retail price of milk is $6 \frac{2}{3}$ cents per quart throughout the year. There are no "model dairies" near the city, and no herds within the city limits. Milk is supplied from dairy farms within a radius of 3 miles.

The milk standard, as given by the health officer, is 12 per cent solids, one-fourth of which shall be butter fat. The cream standard is 25 per cent solids, two-thirds of which shall be butter fat.

No specific amount is appropriated for the supervision of the milk supply. During the past year 8 samples of milk were examined by lactometer, Babcock test, and gravimetric analysis; no bacteriological examinations were made; all the dairy farms were inspected. The inspector states that the milk supply would be improved if dairymen were more particular about keeping the cows' udders clean, and cooling the milk immediately after milking.

\section{CONNECTICUT.}

\section{J. B. Noble, dairy commissioner, Hartford.}

General Statutes, revision of 1887, sections 2660-2664, and Public Acts of 1899, chapter 209 refer to milk, etc. The warden and burgesses of any borough, or the mayor and common council of any city, may appoint a milk inspector, who may 
supervise the milk supply, and is authorized to take samples (but in duplicate when requested); persons selling milk may he required to register with the city or borough clerk, the latter receiving 15 cents from the public treasury for each name registered. It is unlawinl to sell impure or adulterated milk, or knowingly to sell milk from a cow that has heen "adjudged, by the commissioners unon diseases of domestic animals, affected with tuberculosis or other blood disease." Skimmed milk shall be labeled as such when sold.

Public Acts of 1895 , chapter 235, sections 4 and 5, refer to food products, and forbid the sale of articles that are adulterated or misbranded, these terms being defined at length. The State agricultural experiment station may fix standards of purity. The State dairy commissioner conducts prosecutions.

The State exercises very little supervision over market milk. The commissioner has examined numerous samples in connection with the experiment station.

\section{New Haven. (Population, 108,027.)}

[For comparison with other cities in Class I, see p. 26.]

Ward Bailey, elerk of the city board of health.

The average amount of milk consmed daily is 8,750 gallons, or 0.65 pint per capita. The amounts of skimmed milk and cream are not recorded. Milk is distributed from about 400 stores and 200 wagons. Glass bottles are used in the delivery of a large part of the milk supply, most of them being filled in the country. A little of the milk is pastenrized, and the quantity so treaterl does not seem to be increasing. The retail price of milk is 6 cents per quart in summer and 7 cents in winter, producers realizing 3.2 cents and $t$ cents in the two seasons. About half a dozen dairies near the city are conducted considerably better than others, but do not receive an extra price for their milk. There are no herds and only a few milch cows within the eity limits. The average distance from which the milk supply is received is 10 miles.

The milk ordinance refuires that venders of milk shall be licensed by the board of health. License fee is 50 cents, and licenses expire the 1st of each May. They are revocable for canse. The license number must he shown on wagons. The sale of adulterated, etc., milk, which is lefined at length, is prohibited. The milk standard is 11.5 per cent total solids, 3.5 per cent fat, and specific gravity between 1.029 and 1.033. Skimmed milk may be sold if in vessels plainly labeled.

No special appropriation is provided for the supervision of the milk supply, and the entire time of $n 0$ officer is given to this work. During the past year 74 samples of milk were examined with the lactometer and the Babcock test, 25 being found below the standard for butter fat, and 12 dairy farms were inspected.

There is less alulteration of milk now than formerly. There is need of a milk inspector, freguent insipection of dairy farms, and more cleanly methods where milk is produced and handled.

Hartford. (Population, 79,850.)

[For comparison with other cities in Class II, see p. 30.$]$

Edmund D. Roberts, milk inspector.

The daily (ensumption of milk is estimated ats 9,000 gallons, or an average of 0.90 pint per capita, hesides 600 gallons of skimmed milk, and 115 gallons of cream. It is explained that many monesidents take their meals in the city, thus partly accounting for the aplarently large average consumption. Milk is sold from 53 stores and 195 wagens. (ilass buttles are need in the delivery of about one-fourth of the total milk suphly, the greater part of them being filled at the farms. The experience of three darymen who have ahandoned the practice of pasteurizing is proof that there is little or no demand for pastenrized milk in the eity. The retail 
price of milk is 6 to 7 cents per quart in summer and 7 to 8 cents in winter, the producers receiving $2 \frac{1}{2}$ to 3 cents per quart in summer and $3 \frac{1}{2}$ to 4 cents in winter. There are numerous well-conducted daries in this locality, some of which receive as high as 10 cents per quart throughunt the year. Within the city limits there are 20 herds of milch cows, including 300 head, and milk is sent into the city from 171 dairy farms averaging ahout 22 cows each. Ahout:3 per cent of the supply is shipped in by railway, the longest shipment being 20 miles.

Ordinance of Hartford, 1897, chapter 11, sections 15) to :2:, refers to milk. Percons selling milk must be licenserl; fee, 25 cents. The sale of arlulterated or inpure milk is prohibited. The milk inspector has marle a stamdart for milk of 12.3 per cent solids, 3.5 per cent fat.

About 8500 is expended annually in the supervision of the city milk supply, one officer giving the greater part of his time to this work. During the past year (5is 1 samples of milk were examined by lactometer and the Balscock test; all of the city herds and 35 of the 171 dairy farms were inspected; inspections of placess in private residences where milk is kept were marle during the spring, smmmer, ant fall months.

Recent improvements are shown in the care of cows and cleanlinesis in handling the milk. The inspector believes that stringent milk laws may do more harm than good.

\section{Bridgeport. (Population, 70,996.)}

[For comparison with other cities in Class II, see p. 30.]

E. A. McLellan, M. D., health officer.

The daily consumption of milk is estimated as 6.250 gallons, or 0.70 pint per (apita, besides 250 gallons of cream. Noskimmer milk is sold. Milk is sold from 200 stores and 250 wagons. In the delivery of milk, 7 estal,ishments use glass bottles, these being fillerl in the city. No milk is pasteurizerl. The retail price of milk is 7 cents per quart in the summer and 8 cents in the winter season, producers receiving 3 cents per quart in summer and 4 cents in winter. There are no "morlel dairies" near the city. There are 8 herds of milch cows in the city. About onetwelfth of the total milk supply is received hy railway, the longest shipment heing 75 miles.

The city expends nothing in the supervision of its milk supply. Samples of milk are occasionally sent to the State experiment station for analysis. No dairy cattle have been inspected.

Needed improvements, as given, include the inspection of clairy herds, greater cleanliness in handling milk, and proper cooling facilities during the hot season.

\section{Waterbury. (Population, 45,859.)}

[For comparison with other cities in Class III, see p. 34.]

P. T. Keeley, M. D., milk inspector.

The averagre daily consumption of milk is estimated as 5,000 gallons, or 0.57 pint per capita; also 250 gallons of skimmer milk and 250 gallons of cream. Milk is sold from 130 stores and 125 wagons. (ilass hottles, filled in the city, are used in the delivery of 25 per cent of the milk supply. Very little milk is pasteurized, and the practice is not increasing. The retail price of milk is 5 cents per quart in summer and 7 cents in winter, the producers receiving : cents in summer and 4 ? cents in winter. No dairies are conspicuous for being conducterl in a better mamner than others. Within the "town" there are 200 herds, including :3,000 milch cows. Two hundred and fifty dairy farms send milk into the city. About is per cent is received by railway, the longest shipment being 20 miles.

The city expends anmully alout $\$ 1,000$ in the supervision of its milk supply, one official giving his entire time to this work. I uring the past year 1,000 samples were 
examined by Babcock test, lactometer, and gravimetric analysis; two bacteriological examinations were marle for typhus hacilli; all herds supplying the city with milk were inspected four times.

Improvement has recently been shown in the sanitary condition of dairies. Further improvement would result if milk simples and sanitary conditions of dairies were studied by a trained bacteriologist.

New Britain. (Population, 25,998.)

[For comparison with other cities in Class III, see p. 34.]

A. L. Thompson, city clerk.

The daily consumption of milk is estimated as 1,500 gallons, or 0.46 pint per capita, besiles 50 gatlons of skimmed milk and 10 grallons of cream. Nilk is sold from about 30 wagons and no stores. Nearly all the dealers deliver milk in glass bottles, whieh are fillesl at the farms. ('msiderable milk is pastemrized, and this practice is increasing. The retail price of milk is 6 to 7 cents in summer and 7 to 8 cents in winter, producers receiving 5 and 6 cents per quart in the two seasons. There are no dairies near the city which are conducted in an entirely satisfactory manner. one herd of 40 cows within the city limits and 28 heris outside produce the milk supply.

Nothing is done to supervise the milk supply.

\section{DELAWARE.}

This State has no milk law.

Wilmington. (Population, 76,508.)

[For comparison with other cities in Class II, see p: 30.]

Walter A. McEvilly, inspector of milk.

The daily consmption of milk is estimated as :3,756 gallons, or 0.39 pint per capita, besides 250 gallons of skimmerl milk and 25 gallons of cream. Milk is sold from 55 stores and 341 wagons. Ahout one-half of the milk supply is delivered in crlass bottles, some of these being filled in the city and some at the producing farms. No milk is pasteurized. The retail price of milk is 6 cents per quart in summer and 8 cents in winter, producers receiving 3 and 4 cents in the two seasons. There are no so-called model dairies in the vicinity. Within the city limits there are 9 herds, including s.5 cows. Two hundred dairy farms send milk into the city. Ahont ome-half of the total supply is received oy railway, the longest shipment heing 40 miles.

An ordinance arbopted in December, 1901, amending a previous orlinance, relers to milk. Adulterated, etc, milk is prohibited. Skimmed milk must be labeled. The milk standard is 12 per cent total solids, 3 per cent fat.

The city expends annually $\$ 1,500$ in the supervision of its milk supply. Two ofticials-a chemist and an inspector-give their time to this work. The milk inspector recerves 81,000 salary and finds his own implements. Inoring the past year 125 simples of molk were examined hy lactometer; all samples not up to standard were analyzed gravinetrically; 125 samples were examined hacteriologically; all the dary farms sending milk into the elty were inspected, but none of the dairy herds within the city were inspected.

Sugresested improvements include the rigid enforcement of milk laws and the maintenance of prices which will enable dealers to sell the pure article. 


\section{DISTRICT OF COLUMBIA.}

The District laws are the same as those referred to under Washington City.

Washington. (Population, 278,718.)

[For comparison with other cities in Class I, see p. 26.]

William C. Woodward, M. D., health officer.

The daily consumption of milk is estimated as 12,500 gallons, or an average per eapita of 0.36 pint. The amounts of skimmed milk and eream are not known. Milk is sold from $11+$ licensed dairies and about 150 wagons. Glass jars are in general use in the delivery of milk. They are not used for shipping, but are filled in the eity. Perhaps 100 gallons of pasteurized milk is sold daily; this treatment does not seem to be gaining in favor. The retail price is 6 to 8 cents per quart throughout the year, the producers on the farms receiving 2 to 3 cents in summer and 31 to $4 \frac{1}{2}$ cents in winter. (One or two dairies near the city are conducted in an entirely satisfactory manner, and their milk is retailed at 10 to 12 cents per quart. One hundred and thirty-six dairy herds, including 1,127 cows, are within the limits of the District of Columbia, and milk is sent into the District from $6: 30$ dairy farms, the longest shipment being 92 miles.

Chapter 164, Session III, Fifty-third Congress, March, 1895, refers to the milk supply of the District of ('olumbia. A permit from the health officer is required for maintaining a dairy within the District. This is issued after the dairy premises have been inspected and approved. Permit is also required for sending milk into the District, this to be issued if the health officer is satisfied with the detailed description of the dairy farm, and the sworn statement as to the physical condition of the cattle, which must accompany the application. Every person receiving this permit must agree to allow his premises to be inspecterl at any time, and to conform to the health officer's regulations. Permits are issued without charge and are revocable for cause. No person is delarred from selling milk during the time his application for permit is being considererl. Persons recently exposed to contagious disease shall not work in a dairy. Milk wagons must show pernit number, location of dairy, etc. Names of dairymen furnishing milk must be displayed in stores, etc., where milk is sold. The sale of unwholesome or adulterated mitk, or milk from cows fed on swill, etc., or milk from diseased cows, or milk taken from cows less than 15 days before or 10 days after parturition is prohibiterl. Skimmed milk may be sold if plainly labeled; its standard is 9.3 per cent solids.

Chapter 25, Sescion II, Fifty-fifth Congress, refers to foorls. It prohibits adulterated food, the same being defined at length and including milk altered in any way, and it makes the milk standard 9 per cent solids not fat, 3.5 per cent fat, and the cream standard 20 per cent fat.

Inder authority of the first law above mentioned, regulations governing the milk supply are made by the health officer. They specify, in considerable detail, conditions which shall be found where milk is produced and handled, requiring sanitary buildings, pure water for cleaning purposes, cleanly methods, etc.

$A$ (opy of the health officer's regulations for the government of dairies and dairy farms is shown in Appendix I ( $p .167$ ).

Two veterinary surgeons give their entire time, and a chemist part of his time, to the supervision of the milk supply. During the year 413 samples of milk were examined with the Babcock test and lactometer, some of them being analyzed gravimetrically; no bacteriological examinations were made; all the dairy herds in the District were repeatedly inspected, and 205 of the 704 dairy farms were inspected.

The form for application to bring milk into the District is shown in Appendix IV (p. 193). The form for notification of violation of the law is shown in Appendix IV (p. 209). 
Recent improvements are shown in the sanitary conditions of dairy farms and the health of the herds. Recommendations for further improvement include: An official indorsement of properly conducted dairies; the eradication of tuberculosis from dairy herds; better lighting, ventilation, and drainage, and greater cleanliness of barns and dairies; the branding of condemned cows; the immediate cooling of milk and its maintenance at a low temperature till final delivery.

In a special report, dated May 3, 1900, by Dr. J. P. Turner, inspector of live stock and dairy farms, prepared, under the direction of the health officer, in compliance with a resolution of the Senate, much interesting information is given regarding the conditions existing on dairy farms supplying milk and cream to the District and the amount wif work performed in the interest of their improvement. It states that there were in the District 185 farms producing daily 2,000 gallons of milk, some of these farms being insperterl as often as once a month. Only about one-third of the 600 dairy farms in Virginia and Jaryland sending milk into the District hat been inspected. Wherever inspections are made, the following points are included: The physical examination of cows, the sanitary conclition of the barn, methods of cleaning and milking the cows, facilities in the dairy room for cooling and handling milk, and the character of the forl and water supply. Alout 3,500 gallons of milk from uninspected dairy farms were received daily over the Baltimore and Ohio Railroad, and the same amount over the fouthern Railroal. I'ermits are held by all the shippers of this milk, having been given on a basis of their own statements of conditions in their dairies. It is well known that the sanitary conditions on many farms are not such as the health department regulations require, as, whenever the area in which inspections are made is extended, many diseased cows are found and many buildings have to be abandoned or altered. In the inspected area, which supplies about one-third of the milk used in the city, 140 diseased cows were condemned in 1897 and 120 in 1899 . It is shown that not a few of the veterinarian's reports upon herds beyond the insperted districts are unreliable. Tuberculosis is the disease most commonly found, wer 59 per cent of the cows condemned being affected with it. The tuberculin test has been the means of finding many badly diseased animals which conld not be detected by a thorough physical examination. The importance of requiring the removal of diseased cows from dairy farms, after their condemnation, is emphasized. It is recommended also that farmers be reimbursed for at least a part of their loss when their cows are condemned. Many dairy barns have been greatly improved by the construction of good floors and gutters, windows, and ventilators, and the use of whitewash has done much to improve their sanitary condition. The old dark hasement barn is gradually disappearing. In some respects, methods of milking are more cleanly than in the past, though there is yet much room for improvement. ("ows are kept fairly clean, but the filthy habit of "wet" milking and the neglect of personal cleanliness prevails in too many dairies. The use of separate milk rooms and the cooling of milk to below $50^{\circ} \mathrm{F}$. is strongly recommended. The feeds given milch cows are generally satiufactory. Some farmers are using ensilage and no unfavorable results have been noted when the silo was properly built and filled. In making inspections, special attention is given to the water supply.

The report above abstracted was accompanied by one from the chemist and inspector of dairy products. The only forms of intentional adulteration of milk are the addition of water, coloring matter, and preservatives, and the removal of cream. A few years ago these were very common, but to-day they exist only to a small exient. Inintentional forms of adulteration, through which different forms of bacteria, including the germs of disease that are most likely to enter the milk, are discusserl at length. The amount of acidity found in 146 samples of milk, collected, in one vear, varied between wide limits; 5 samples contained from 1.08 to 3.25 , the remaining 141 varied from 0.27 to 0.96 per eent acility, their average being 0.52 per cent. 
During a recent winter a bacteriological study of the milk sold in the District was made by the veterinary inspector, the bacterial content per cubic centimeter was found to vary from 2,500 to $100,000,000$. Of 117 samples examined, 9 contained more than 1,000,000 bacteria per cuhic centimeter, 36 contained from 100,000 to $1,000,000$, and 20 contained less than 10,000 per cubic centimeter.

\section{FLORIDA.}

Revised Statutes, sections 2659 and 2660 , refer to foorls. It is unlawful to sell diseased or unwholesome food except when the buyer is fully informed, and the sale of food adulterated with any substance injurious to health is forbidden.

Jacksonville. (Population, 28,429.)

[For comparison with other cities in Class III, see p. 34.]

Claude Joyner, health officer.

The daily consumption of milk is estimated at 1,200 gallons, or 0.34 pint per capita. Milk is sold from Th stores and 35 wagons. About one-half of the milk is supplied in glass bottles, and these are filled at the farms. A large amount of milk is pasteurized, but the practice is not increasing. Milk is retailed at 10 cents per quart throughout the year, the producers receiving 7 cents per quart. There are no "model dairies" near the city. There are no dairy herds within the city limits. The milk supply is produced by 560 cows on 35 dairy farms, within 4 miles of the city.

An ordinance adopted in April, 1888, and amended in October, 1899, refers to milk. The health ofticer must examine the city milk supply. License is required for the sale of milk. Adulteraterl, etc., milk is prohibiterl. The water at dairies must be pure. The milk standard is 12 per cent solids, 3 per cent fat, board of health lactometer reading of $100^{\circ}$ at $60^{\circ} \mathrm{F}$, and show " 6 per cent of cream by the lactometer."

During the past year 185 samples of milk were examined hy lactometer and Babcock test, and all the dairy farms were inspected.

\section{GEORGIA.}

Acts of 1895 , part 1 , title 7 , No. 207, sections 1 and 2, refer to milk. The sale of unclean, unwholesome, or alulterateri milk, or milk from an animal less than 15 days before or 5 days after parturition is prohibiterl. The milk standard is 3.5 per cent fat, 8.5 per cent other solids. Skimmed milk and buttermilk may be sold as such.

\section{Atlanta. (Population, 89,872.)}

[For comparison with other cities in Class II, see p. 30.]

George M. Hope, chief of the sanitary department.

Estimated amount of milk used daily is 1,500 gallons, or 0.13 pint per capita; also 300 gallons of skimmed milk, 101 gallıns of eream, and 2,500 gallons of buttermilk. Milk is distributed from 10 stores and 350 wagons. (ilass jars are used to a certain extent, being filled in the country or in the delivery wagons in the eity. None of the milk is pasteurized. The retail price per quart for milk is 5 cents in summer and 6 cents in winter, producers receiving 3 cents in summer and $t$ cents in winter. The few "model dairies" sell their product at 7 cents per quart in summer and 9 cents $m$ winter. Abont 2,129 milch cows in : 'ity herds and 350 country herds furnish the city with milk. Only about 300 gallons of milk are received by railway, the longest shipment being 20 miles. 
Two inspectors devote a large part of their time to the supervision of the city milk supply, having examined during the past year 1,250 samples chemically, but none bacteriologically; and inspected all of the city dairies and nearly all of the farms sending milk into the city. A report issued by the city board of health in 1899 shows that about 8 per cent of the samples analyzed failed to come up to the requirements of the law, while 62 per cent showerl more than 13 per cent total solids.

It is claimed that the milk standard should be raised.

\section{Savannah. (Population, 54,244.)}

[For comparison with other eities in Class II, see p. 30.]

\section{W. F. Bunner, health officer.}

The daily consumption of milk is estimated as 3,000 gallons, or 0.44 pint per ("apita, besides an unknown quantity of skimmed milk and eream. Milk is sold from 10 stores and numerous wagons. Glass bottles are used in the delivery of unilk by all the best dairy establishments. Those outside the city fill the bottles at the producing furms. No milk is pasteurized. Milk retails for about 10 cents per quart throughout the year. Three dairies near the city are conducted in a very satisfactory manner, their milk selling at the regular rate. The number of herds of milch cows within the city is not known, but about 15 dairy farms wend milk into the eity. Practically all the milk used is produced within a radius of 5 miles.

The city has no ordinance regulating the milk supply and no work has been clone along this line.

Recent inprovements are due to the introduction of high-grade cattle, better water supply at dairies, and more care in the conduct of the dairy business. Milk ordinances are very much needed.

\section{Augusta. (Population, 39,441.)}

\section{[For comparison with other eities in Class III, see p. 34.]}

Thomas D. Coleman, M. D., secretary of the board of health.

The average amount of milk sold daily is estimated as 600 gallons, or 0.12 pint per capita. In explanation of this apparently low per (apita consumption of milk, it is stated that many families keep 1 or 2 cows, and that the milk from these is not included in the above estimate. Milk is sold from 1 store and 30 wagons. Nearly all the dairymen use glass bottles in the delivery of milk, and these are filled at the farms. No milk is jasteurized. The retail price of milk is 4 to $6 \frac{1}{4}$ cents in summer, and $6 \frac{1}{4}$ to $7 \frac{1}{2}$ cents in winter. There are no "morlel dairies" near the city. Dairy herds are not allowed in the eity. Milk is sent in from about 20 dairy farms, the most distant being 6 miles from the city.

The city conducts no inspection of the milk or herds.

\section{HAWAII.}

Laws of 1898 , act No. 34, refers to foods. It forbids the sale of any adulterater food, which term is defined at length and so as to include impure milk.

Honolulu. (Population, 39,306.)

[For comparison with other cities in Class III, see p. 34.]

Edmund C. Shorey, food commissioner for Hawaiian Territory.

About 1,000 gallons of milk is sold daily by milkmen, or 0.20 pint per capita, besides 12 gallons of cream. No skimmed milk is sold as such. In explanation of the small amount of milk reported, it is stated that some private families keep eows and sell milk to their neighbors, and that canned comdensed milk instead of natural milk is used largely by native Ilawaians, Awiaties, and others. Milk is sold from 
30 wagons, and cream is sold from 3 stores. (ilass hottles are used in the delivery of most cream sold, but not for milk. No milk is pasteurized, but a small quantity of cream is thus treated, and the practice is increasing. Some sterilized cream comes from California. The retail price of milk is 10 to 15 cents per quart throughout the year, and of cream 50 to 60 cents per pint. Producers of milk in all cases retail their own product. Nodairy near the city is conducted in an entirely satisfactory manner. Thirty-seven herds, including about 900 cows, and located within 6 miles from the center of the city, furnish the milk supply; one herd more distant supplies milk and cream to steamships.

No milk standard has been fixed by law, but the minimum ohtained hy numerous analyses is used for comparison in prosecutions. License fee for selling milk is $\$ 2.50$.

In the supervision of its milk supply the city expented last year $\$ 1,660-\$ 700$ to the food commissioner, or one-third of his salary, $\$ 900$ to the milk inspector, and $\$ 60$ for lahoratory expenses. The milk inspector gives his entire time to this work. During the past year 700 samples of milk were exanined for composition by the lactometer and Babcock test, and in suspicious cases hy gravimetric analyses (very few samples were examined in Jannary and February on account of an epidemic of plague); no samples were examined bacteriologically; 10 herds were tested with tubereulin. Milk has heen fomm to eontain as high as 40 per cent of arded water. In the year there were 11 proserntions for the sale of adulterated milk, resulting in 9 convictions with fines from $\$ 25$ to $\$ 100$. The milk inspector's analyses of herd milk known to be pure showed an average of 12 per cent wolich, 3.5 per cent hutter fat, mininum solids 11 per cent, and minimum fat 2.5 per cent. Dairy work is often conducted in a very crude munner; many of the employees are Japanese or Portuguese, and ignorant of modern methods. It is a common practice to allow the calves heing raised to suckle the cows. The calf is usually allowerl to take the last of the milk, which is the richest in fat. A number of analyses of herd milk, showing the results of allowing the calves to take the first or last portion of the milk in the udder, or none at all, are as follows: .

\begin{tabular}{|c|c|c|}
\hline Part of milk taken by calves. & $\begin{array}{l}\text { Total } \\
\text { solids. }\end{array}$ & $\begin{array}{c}\text { Butter } \\
\text { fat. }\end{array}$ \\
\hline When the calres took the first part of the milk... & 13.2 & 4.6 \\
\hline When the calves were allowed to have none........ & 12.8 & 4.0 \\
\hline When a few calves took the last part of the milk ...... & 12.5 & 3.6 \\
\hline When a large number took the last part of the milk... & 11.5 & 2.8 \\
\hline
\end{tabular}

Recent improvement in the milk supply is due to less adulteration with water and better care of milk utensil., the latter resulting in less sour and ropy milk. It is stated that a milk standard should be fixed, and information regarding the care of cows and milk should be distributed to dairymen.

IDAHO.

Revised Statutes of 1897 -section 6918 refers to foods. The adulteration of any article of food or drink with fraudulent intent, or sale of same as unadulterated, is a misdemeanor.

\section{ILLINOIS.}

Alfred H. Jones, State food commissioner, Chicago.

Laws of 1879 , page 111 , and 1897 , page 268 , refer to milk. Cows producing market milk must not be kept in an unhealthy condition, nor shall any person (knowingly) give them unwholesome food, which inclucles "distillery waste, usually called 'swill,' " and other substances in a state of putrefaction. It is unlawful to sell milk or cream adulterated by the addition of water or any foreign substance. The milk 
standard is 12 per cent solids, 3 per cent fat. Skimmed milk shall be sold as such in any city and only from cans plainly laheled. Persons retailing milk in cities shall have plainly marked on each can and vehicle the name of the owner and the name of the locality where the milk is produced. Condenserl milk shall be made from milk containing at least 3 per cent of butter fat and evaporated to one-third or lese of original volume; the word "cream" on cans is evidence of fraud; condensed skimmed milk must be labeled. The addition of sugar to condensed milk is permitted. Canned goods must be labeled to show grate and name of manufacturer.

Laws of 1899, page 368, refer to the State food commissioner. It is his duty to enforce all dairy laws, to inspect fools believerl to be 1 mhealthful or adulterated, and to prosecute for their sale. State's attorneys assist in prosecutions. This law forbids the sale of foods that are adulterated, which term is defined at length, and under its authority the commissioner has announced the following standards: Milk, 3 per cent fat; "coffee cream," 15 per cent fat; "whipping cream," 22 per cent fat.

Chicago. (Population, 1,698,575.)

[For comparison with other cities in Class I, see p. 26.]

Thomas F. Grady, superintendent of milk inspection, board of health.

Adolph Gehrmann, M. D., director of laboratory, board of health.

It is estimated that 169,465 gallons of milk are used daily. This is equivalent to a supply of 0.8 pint per capita, hut it is probable that this does not represent the average per capita consumption becatise a considerable quantity of the milk is used in the manufacture of oleomargarine, and much is consumed daily in the city by persons not included in its stated population. The amounts of skimmed milk and cream are not known. There are 4,629 firms engaged in selling milk; 2,162 of these sell from licensed stores, 1,867 sell from 2,692 licenserl wagons; and 600 parties sell milk from their own cows. About one-third of the milk peddlers use glass bottles for a part of their trade and only 49 of these sterilize the bottles. Over 115,000 quarts of bottled milk come into the city each day, half of it heing supplied by a single firm. Only two concerns fill all of their bottles in the comtry. Pastenrized milk is used but little, and it is not gatining in favor. The retail price per quart of milk is 5 to 7 cents in the summer and i $t 07$ cents in the winter season, the producers on the farms being paid in the two seasons $2 \frac{1}{2}$ cents and $3 \frac{1}{2}$ cents, respectively, $a$ The milk from

"The Milk Newn is repm-ible for the following table, which shows a considerable increase in the price paid to milk shippers. The figures were compiled from shippers' books and oftice recork and represent the price prevailing the longest time in each month. Prices given are for 8 -gallon cans delivered on the Chicago platform, freight prepaid:

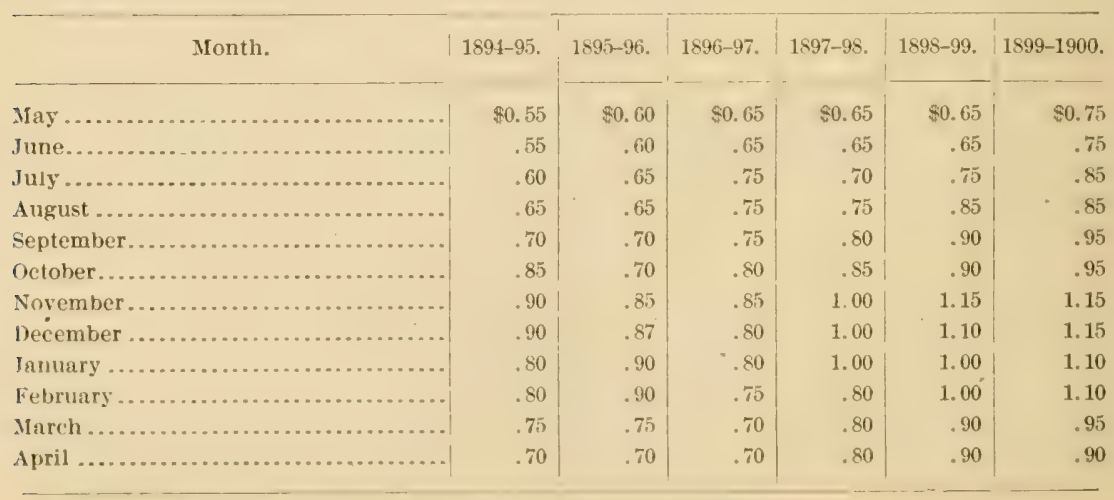


two dairies near Chicago, which are conducted in an entirely satisfactory manner, is sold throughout the year for from $\tau$ to 12 cents per quart. Within the city limits there are 30 dairy herds, including 420 cows, besides 1,830 cows kept privately, 1, 2, or 3 , in a place. The amount of milk produced by the city cows is 4,500 gallons daily. Milk is sent into the city from 4,000 dairy farms, and about 97 per cent of their product is shipped in over 16 railroads, the longest shipment being 123 miles. The charge for hauling an 8 -gallon can of milk varies from 8 to alout 22 cents.

Sections $933-965$ of the municipal corle relate to the eity milk supply. Among their provisions are the following: A milk and food division is created in the department of health, the chief ofticer being known as the superintentent. He and his first aswistant must each give bond for $\$ 5,000$, and each inspector must give hom for $\$ 2,000$. The officers are supplied with badges and are given neeseary authority for making inspections. No inspector is allowed to serve in one district longer than four consecutive weeks, at the end of which time he can not again serve there until he has served in at least two other districts. Licenses, to he renewed the first of each May, must be obtained by milk or cream sellers (excepting persons owning 1 or 2 cows, and hotels, restaurants, etc., where milk or 'ream is furnished with meals); the fee is $\$ 10$ for each store and each wagon. Licenses will be granterl for a portion of the year at a proportionate rate. They must be displayed in stores, and delivery wagons must bear metal signs obtained from the city clerk showing that they have been licensed. The milk standard is 12 per cent total solids, 3 per cent butter fat; cream standard 15 per cent hutter fat; skimmed milk may be sold if plainly labeled by means of a metallic tag; buttermilk is allowed if pure. Condensed nilk must he made from pure milk and be in packages plainly labeled to show by whom condensed. The ordinance prohibits the sale of milk or cream for human food which is unclean, impure, adulterated by the addition of water or any foreign substance; milk or cream from diseased cows, cows within fifteen days before and twelve days after parturition, cows kept in an unhealthy condition or fed distillery or brewery refuse or other fermented food; milk or cream exposed to infection from diseased persons or animals. Impure milk and cream, including the product of diseased cows or cows fed on refuse, etc., shall be confiscated when found. Cow stalles (in the city?) shall be washed out and thoroughly cleaned each week. Milk vessels, refrigerators, and all places where milk is stored must be kept scrupulously clean.

The ordinance sections regarding qualifications, requirements, and duties of milkinspection officials are given in Appendix I (p. 177).

The ordinance section referring to signs on delivery vehicles is given in Appendix I (p. 17\%).

The city expends annually in the supervision of its milk supply about $\$ 10,000$, and 7 officials - 1 superintednent, 5 inspectors, and 1 milk tester-give their entire time to this work. During the past year 19,05:3 samples of milk and cream were examined by the Babcosk test and lactometer and some of them by gravimetric analysis, and 126 samples were examined, upon requests of citizens, for tubercle bacilli. "Of the 19,053 samples of milk and cream analyzed 4,926 were brought to the laboratory by private individuals (the remaining 14,127 were collecter by the milk inspectors). Of the 14,127 inspectors' samples 1,813 where tagged skimmed milk and 7,970 were not tagged, therefore sold for whole milk; of these, 859 were found below grade. Out of 4,344 samples of cream, $15 t$ were found below grade. Percentage of inspectors' samples of milk and cream helow grate, 7.17. Of the 4,926 samples brought to the office by private individuals, 3,107 were milk, of which 328 were below grade, and 1,813 were cream, of which 104 were below grade. Percentage of samples of milk and cream brought to office found below grade, 8.77. Percentage below grade, 
all sources, 7.58. $a$ The numbers of examinations made each month, with their results, are shown in the table following. The daily records of the examinations of milk are kept on forms similar to this table:

a In a report of the department of health it is shown that the percentage of nilk samples found below grade in the last eight years has been as follows:

\begin{tabular}{|c|c|}
\hline Per cent. & Per cent. \\
\hline$\ldots \ldots .45 .4$ & $\ldots 5.8$ \\
\hline$\ldots \ldots \ldots .7$ & $1898 \ldots$ \\
\hline … & $1899 \ldots \ldots \ldots \ldots \ldots$ \\
\hline $1896 \ldots \ldots \ldots \ldots \ldots \ldots \ldots$ & $1900 \ldots \ldots \ldots \ldots \ldots \ldots \ldots$ \\
\hline
\end{tabular}

Commissioner Reynolds calls attention to the fact that in this period there has been a decided decrease in the mortality of infants. 


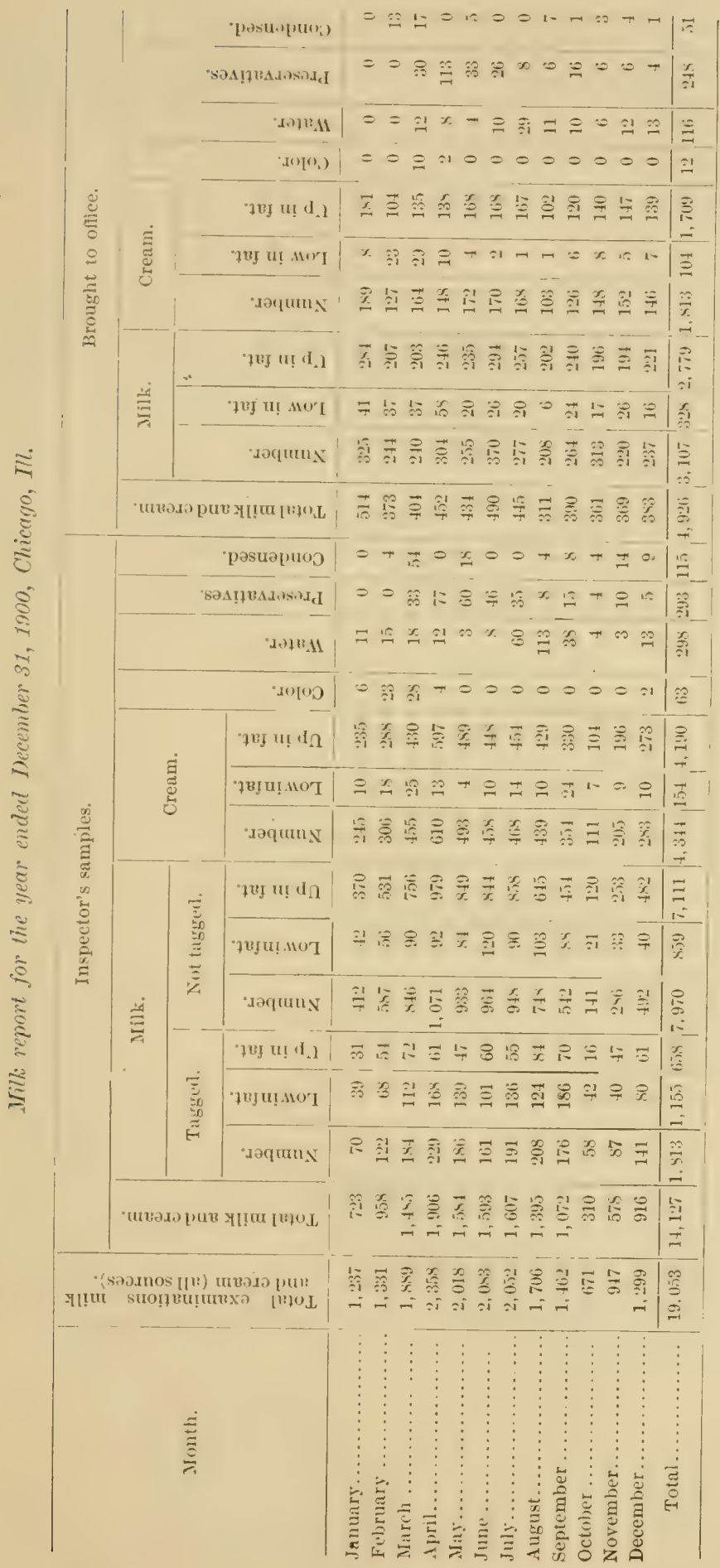

$25839-\Lambda^{\top}$. $46-03-5$ 
Inspection of premises in the eity where milk is handled shows the following:

\begin{tabular}{|c|c|c|c|}
\hline Condition of premises. & Stores. & $\begin{array}{l}\text { Peddlers' } \\
\text { premises. }\end{array}$ & $\begin{array}{c}\text { Premises } \\
\text { where cows } \\
\text { are kept. }\end{array}$ \\
\hline Good sanitary condition... & 1,100 & 839 & 194 \\
\hline Fair sanitary condition..... & 1,043 & 929 & $\$ 11$ \\
\hline Bad sanitary condition . . . . . . . . . . . . . . & 10 & 90 & 48 \\
\hline Not reported upon ............................. & 9 & 9 & 45 \\
\hline Total ................ & 2,162 & 1,867 & 698 \\
\hline
\end{tabular}

There were during the year 618 prosecutions-99 for selling milk or eream helow stanclard and 519 for selling without lieense; 357 were settled by the payment of costs, and 176 by fines of $\$ 25$ or more. All of the dairy herds within the city and 11 of the 4,000 outside have been inspected during the past year.

The form for application for milk license is shown in Appendix.IV (p. 188).

Recent improvement in market milk is shown by its larger average fat content than formerly and the dereasing uwe of preservatives. Recommendations as given inclule a thorough system of dairy inspection with the assistance of State authorities, the registration of dairies and certification as to their sanitary condition, the use of the tuberculin test, and frequent instead of occasional or no inspections.

\section{Peoria. (Population, 56,100.)}

[For comparison with other cities in Class II, see p. 30.]

F. C. Bourscheidt, M. D., commissioner of health.

The daily eonsmmption of milk is estinated as 5,000 grallons, or 0.71 pint per cap)ita, hesides 500 gallons of skimmed milk and 450 gallons of cream. Milk is sold from 45 stores and 80 wagons. Glass bottles are deed in the delivery of milk from 6 or 8 establishments, the greater part of these being filled at the producing farms. No milk is pastemrized. The retail price of milk is 5 to 6 cents per quart in summer and 5 to 7 cents in winter, the producers receiving :3 cents per quart in summer and $3 \frac{1}{2}$ cents in winter. There are no "model dairies" in or near the city. There are 2:) dairy herds, incluling 446 head, within the eity limits, and 5 s dairy farms, with 1.262 cows, send milk into the city. Alout 200 gallons of cream is shiped into the city by railway, the longest shipment being 50 miles.

An orlinance adopted Octoher, 1899 , refers to milk. License fee for selling milk is \$5. The board of health may require the examination of all cows whose milk comes to the city, the owner paying 25 cents per cow. Milk from cows that are diseased, ete., milk from a place where a contagious disease exists, or adulterated milk, is prohibiter. Milk standard, 12 per cent solids, 3 per cent fat; cream standard, 25 per cent solids, two-thirds of which must be fat. Skimmerl milk must be labeled.

Fifteen hundred dollars is expended amnually in the supervision of the milk supply. The commissioner and one assistant give a part of their time to this work. During the past year 655 samples of milk and 115 samples of cream were examined by the Babcok test; 35 samples were examined hacteriologieally; all dairy herds in the city and 73 of the 78 dairy farms were inspected.

\section{Quincy. (Population, 36,252.)}

[For comparison with other eities in Class III, seen I, 31.]

William IIild, secretary of the board of health.

The daily consumption of milk is estimated as 1,500 gallons, or 0.33 pint per capita, besides 1,000 gallons of skimmed milk and 500 gallons of cream. This is sold from 
30 stores and 20 wagons. Glass bottles, filled at the producing farms, are used by :? dairies. Very little milk is pasteurized, and the pratetice seems to be increalsing. IIilk is retailed, at 5 cents per quart thromghout the year, and is supplied from 20 dairy farms, all within 5 miles of the city.

There is no supervision of the city milk supply.

\section{Springfield. (Population, 34,159.)}

[For comparison with other eities in Class III, see P. 34.]

Frank N. Patterson, sanitary inspector.

Estimated arerage daily consmution of milk is 2,50) gallons, or (1).5!) pint fur (apita. Milk is sold from 4 stores and $t 5$ wagons. W'ithin the city limits there are 7 herds, including 63 cows, and milk is sent in from 28 . dairy farms. About 6 per cent is received by rail, the longest shipment being 20 miles.

An ordinance adopted in July, 1897, regulates the milk supply. The health officer or sanitary inspector must make a thorough inspection of conditions existing at all premises wheremilk is sold. Anmual license fee is s., lout "private persoms" keeping 1 or more cows, and who sell to their customers hy perldling same hy hand, are exempt from license fee. Each nitk wagon must bear a painterl metal plate, furnished with the license. Adulterated milk or cream is prohibiterl. The milk standard is 12 per cent solids, 3 per cent fat; cream standard, 15 per cent fat. Skimmed-milk containers nust be tagged with a metal plate, :3 hy 5 inches in size. Hotel keepers, restaurant keepers, and hoarding-house keepers are subject to the provisions of this ordinance, except the obtaining of a license.

During the fast year 35 : samples of milk were examined hy lactometer and Bal)(ock test; no bacteriological examinations were made; all the eity herds, and $1: 3$ of the 28 dairy farms, were examined.

\section{Rockford. (Population, 31,051.)}

L. W. Brown, mayor.

This city has no milk inspector, and there is no supervision of its milk supply.

\section{East St. Louis. (Population, 29,655.)}

M. M. Stephens, mayor.

This city has no milk inspector, and information regarding its milk supply is not available.

\section{Joliet. (Population, 29,353.)}

[For comparison with other cities in Class III, see p. 34.]

John R. Casey, M. D., health commissioner.

The daily consumption of milk is estimated as 2,400 gallons, ur 0.65 pint per cappita, besides 15 gallons of cream. No skin!med milk is sold. Milk is sold from 8 stores and 55 wagons. Very little milk is delivered in glass bottles, and these are filled, soure at the farms and some in the city. Only two dealers pasteurize milk and the practice is not increasing. The retail price is 5 cents per quart throughout the year, producers receiving 2! cents. There is no herd near the city conducted in an entirely satisfactory manner. There are no city herds of milch cows. Milk is brought in wagons from 40 dairy farms within 5 miles of the city.

A city ordinance, Nay, 1897, requires dairymen to furnish to the health commissioner a description of all their milch cows, a sample of milk obtained therefom, and a sample of the water used in washing milk cans, ete. All the herds must be tested with tuberculin. The milk stamlard, as given by the health commissioner, is 3 per cent fat; specific gravity, not less than 1.028. 
Nothing is alpropriated especially for the supervision of the milk supply. During the past year 300 samples of milk were examined by the lactometer, and all the dairy farms were inspected.

It is recommender that all cows should be subjected to the tuberculin test.

Aurora. (Population, 24,147.)

[For comparison with other eities in Class IV, see 1 . 40.]

J. W. MacDonald, health officer.

The daily consumption or milk is estimated as 1,500 gallons, or 0.50 pint per cappita, besicles 100 grallons of skimmed milk and 50 gallons of (ream. Milk is sold from It stores aml 4:3 wagons, and about three-fourth of it is delivered in ghiss leottles, which are filled in the city. About 10 per cent of the entire anount is pasteurized, and this practice is increasing. The retail price of milk is 5 cents per quart throughout the year, producers receiving $2 \frac{1}{4}$ and 3 cents, summer and winter, respectively. The milk from one "model dairy" near the city is sold for 12 cents per quart. Within the city there are 2 herds, including 40 cows, and milk is sent in from about 100 dairy farms, the most distant being 8 miles from the city.

An orilinane of November, 1897 , consisting of 21 sections, refers especially to milk. Another ordinance, relating to food and drink, refers in general terms to milk. License for the sale of milk or cream is $\$ 5$; each wagon after the first, $\$ 5$; but persons owning not more than 2 cows are exempt. Impure, adulterated, etc., milk is prohibited. The milk standard is 12 per cent milk solids, 3 per cent fat; cream standard, 15 per cent fat. Condensed milk must be from pure milk and contain the right progortion of milk solids and fat. Skimmed milk must be labeled. Buttermilk is permitted if made from pure milk. Milk premises, utensils, ete, must be kept clean. Milk wagons must bear metal sign. Cows must be given pure food and water.

About $\$ 300$ is expented anmually in the supervision of the milk supply, one official giving a part of his time to this work. During the past year 314 samples were examined by lactometer and Babeock test; 15 samples were examined bacteriologically for tuberele bacilli; the city herds, but none of the dairy farms, were inspected.

Recent improvement is due to greater cleanliness obtaining at dairies amd to the practice of pasteurizing. It is stated that all cows shonld be tested for tubereulosis and all dairies as to sanitary combition, and there should be a more frequent inspection of the milk.

\section{Evanston. (Population, 19,259.)}

[For comparison with other cities in Class IV, see 1. 40.]

William R. Parkes, M. D., health commissioner.

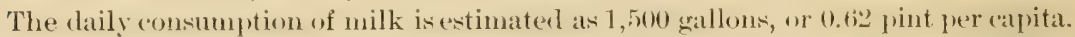
Milk is sold from 10 stores and to wagons, there besing $2: 3$ dealers. dilass bottles, filled in the city, are used almost universally in the delivery of milk. No milk is pasteurized. The retail price is 6 cents in summer and 7 to 10 cents in winter, producers receiving 4 cents and 5 cents in the two seasons. The milk from two dairies, conducted on a better plan than others, is sold for 8 cents per quart in summer and 10 cents in winter. Within the city limits there are 7 herds, including 400 cows, and milk is sent in from 37 dairy farms. About 35 per cent is received by railway, the longest shipment being 75 miles.

City ordinances, Chapter XLVI, sections 653-681, refer to milk. License fee for the sale of milk or eream is $\$ 5$ for each store and wagen; eath additional wagon, s.2. This does not apply to persons who own 1 or more cows and peddle milk to their neighbors. Impure, adulterated, ete., milk is prohibited. The milk stambarl is 1:3 per cent solids, :) per cent butter fat; the cream standard is 15 per cent butter fat. 
Skimmed milk must be labeled. Condensed milk and buttermilk must he from pure milk. Milk from diseased cows may be confiscated. ('ow stables must he washed ont at least once a week.

The health officer and the sanitary inspector give a part of their tine to the supervision of the milk supply. Inring the past year to samples of milk were examined by the lactometer, Babcock test, and gravimetric analysis. No bacteriological examinations were made. All the city herds and 25 of the 37 dairy farms were inspected. Four herds were subjected to the tuberculin test and 6 cows were condemnerl.

It is stated that all tubercular cows should be disposest of, and the tulecroblin test. should be used for their detection.

\section{Moline. (Population, 17,248. )}

[For comparison with other cities in Class IV, see p. 40.]

Ed. Kittilsen, city marshal and health oflicer.

The daity consumption of milk is entimaterl as 575 gallons, or 0.27 pint per capita. Milk is wold from 1 store aid :34 wagons, and a jart of it is delivered in glass bottles, filled at the farms; nome is pasteurized. The retail price is 5 cents per quart throughout the year, producers receiving 3 cents. There are no "model dairies" near the city. Within the city limits there is 1 herd ( 30 cows), and milk is sent from 30 dairy farms. The longest shipment of milk by railway is 10 miles.

The city has no milk ordinance.

Dhring the past year :3:3 samples of milk were examinesl by the Babeork test, and 24 of the 30 dairy farms were inspected.

Ottawa. (Population, 10,58s.)

[For comparison with other eities in Class IV, see p. 40.]

W. F. Weese, V. S., acting dairy inspector.

The daily consmuption of milk is estimated as 600 gallons, or 0.45 pint, per capita. Nilk is sold from 15 wagons, but from nostores. Alout one-fourth of it is delisered in ghass hottles, which are filled at the farms; none is pastemized. The retail price is 5 cents per quart in summer and 6 cents in winter, producers receiving $2 \frac{1}{2}$ and 3 cents in the two seasons. There are no "model dairies" near the city. Within the city limits there are 3 herds, including 25 (nw, and milk is supplied from $1: 3$ dairy farms, all within a radius of 4 miles.

Revised ordinances adopted in June, 1899, and August, 1899, refer to milk. License fee for the sale of milk or erean is sil for each cow. Cows must be free from contagions and infectious disease. Provision is made for the use of the tuberoulin test.

Four hundred dollars is expended ammually in the supervision of the milk supply, one oflicial giving a part of his time to this work. During the past year 13 samples of milk were examined by the lactometer and Baheock test; no hacteriological examinations were made; all the city herds and 11 of the 13 dairy farms were inspected.

Recent improvements in the milk supply include an inerease in the butter fat content, creater cleanliness in handling, and the removal of all tubereulous cows from chiry herds. Needer improvements stated inchule the enforement of more stringent sanitary measures at the producing farms and the more frequent testing of milk.

\section{INDIANA.}

J. N. Iurty, M. D., secretary of the board of health, Indianapolis.

Horner's Revised Statutes, 1897 -section 2071 refers to milk. It is unlawful to knowingly sell milk that is adulteraterl or skimmed, or milk from a cow that is diseased or fed upon deleterious foods, including the refuse of a distillery or brewery. 
Acts of 18:9-chapter 121 refers to foods. Its enforcement is charged to the State loard of health. It forbids the sale of adulterated food, which is defined at length, and under its authority the state board of health has establisherl the following standarik and rules: Milk shall contain at least :3 per cent fat, 9 per cent other solids: no coloring matter or antiseptic is permitted; it shall not be sold when taken less than twenty-one days before or four days after calving, nor when from a cow that is diseased or fed upon damaged food.

The buard of health has issued rules describing in detail conditions which shond be found and methods which should be followerl at dairies.

As no appropriation has been made for the enforcement of the food law, the State board of health has been unable to take action under its anthority.

\section{Indianapolis. (Population, 169,164.)}

[For comparison with other eities in Class I, see p. 26.]

\section{A. F. Zearing, clerk of the board of public health.}

The daily consumption of milk is estimated as 12,000 gallons, or 0.57 pint per (alpita. It is estimated also that 8,000 gallons of skimmed milk and $t, 000$ gallons of (ream are consumerl daily. Milk is sold from 770 stores and 27:3 wagons. Glass jars are used almost exclusively in its delivery, and these are filled both on the farms and in the eity. A small amount of milk is pastenrized and this treatment is increasing in favor. The retail price per quart is 5 cents in summer and 6 cents in winter, and the producers receive 21 and 3 cents in the two seasons. A large portion of the dairies are conducterl in a very satisfactory manner. Twenty-five herds, including 180 milch cows, are within the city limits, and 250 dairy farms sencl milk into the ('ity. Five per cent of the total supply is received by rail, the longest shipment being 40 miles.

Dairies must be linensed and ohserve certain regulations atopted by the lowal of public health and charities, January, 1896, under authority of ordinance No. 71, December, 1895. License fee for sale of milk is 50 cents. The regulations require that dairy stables be constructed and the work be conlueted in a sanitary manner; the requirements are detailed, some of them being: 111 animals except dairy stock

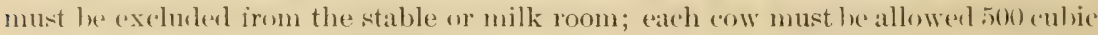
feet air space; each cow must be clcaned daily and be properly fed and watered; cans must be scalded daily; milk mist he strained and cooled to $58^{\circ} \mathrm{F}$. promptly after milking; no milk must be used from cows sixty days before or twelve days after calving; the board of health must be promptly notified of the disovery of disease; and the tuberculin test may be required on suspected cows, etc. The milk standard is 9 per cent solids not fat, 3 per cent fat.

Regulations governing dairies are shown in Appendix I (p. 171).

()ne thomsam dollars is appmpriated ammally for the supervision of the rity milk supply, and one inspector gives his entire time to this work. During the past year 850 samples of milk were exanined hy lactometer, Babock test, and gravinetric analywin; 14 samples were examined lateriologically, and the eity milch eows and 204 of the 250 dairy farms were inspected.

The superior quality of the milk supply of Indianapolis is due in mo small measure to a plan put in operation hy the health officials a few years ago wherely the dairymen who kept their dairies up to the highest standard received special certifieates of appoval. These were helpful in obtaining new trale and were therefore grenerally somght after, with the result that sanitary methods were introduced into many places where they would not otherwise lave been found. "

" Market Milk: A Plan for its Improvement. Seventeenth An. Kpt. Bu. An. Ind., pp. 158-193. 
The most marked recent improvement has resulted from prosecutions for the use of formaldehyde" as a preservative, and in compelling greater cleanliness in the handling of milk.

\section{Evansville. (Population, 59,007.)}

[For comparison with other cities in Class II, see p. 30.]

\section{J. H. Kerth, milk and food inspector.}

The daily consumption of milk is entimated as 2,500 gallons, or 0.34 pint per eapita. Milk is sold from :3 stores and 60 wagons. In the delivery of milk wlass bottles are used by two dairy establishments. One of these fills the bottles in the city, the other at the producing farm. No milk is pasteurized. The average retail price of milk is ahout $6_{4}^{1}$ cents per quart throughout the year. There is one well-conducted dairy near the city, but it receives no advance in price for its product. Within the city limits there are 5 herds of milch cows, including 60 head, and 54 dairy farms send milk into the city. No milk is shipped in by railway, the supply coming by wagons as far as 9 miles.

Ordinance No. 31, October, 1893, regulates the milk supply. License to sell milk is granted free of charge. Unwholesome or adulterated milk, "swill milk," and milk from unhealthy cows is prohibited. The inspector must inspect at least once a month all dairies, including cows, milk, vessels, etc.

Nine hundred dollars is expended annually in the supervision of the milk supply. One officer, as milk and food inspector, gives his entire time to this work. During the past year 215 samples of milk were examined by lactometer, the Bahenck test for fat, and by a qualitative test for formaldehyde; no bacteriolocrical examinations were made; all of the city herds and all the dairy farms were inspected.

Recently the sale of milk containing preservatives has dexpeased and greater cleanliness has obtained in the production of milk.

Sugrested improvements as given, include a higher milk standard and a more frequent inspection of dairies and dairy products.

"Regarding the use of formakdehyde as a preservative in milk, the following statement, attributed to Dr. Morrison, health officer of Indianapolis, is reprinted:

My experiments were undertaken by reason of some prosecutions here for the sale of allulterated milk. Total number of experiments, 96 ; preservative, formaldehyrle. Milk was secured direct from the cow and immediately transferred to tent tubes." In each test tuhe was placed 6 c. (. of this milk. The tubes were placed upon racks in rows, each row containing a "control" tube, five tubes in each row, so that the average result could be obtained.

In row No. 1, pure milk; all other rows, one pure and four adulteraterl. To one row was arlded artificial gastric juice, prepared from Fairchild's pepsin. Exactly the same in same amounts applied to each of the tubes in other rows. Previons to futting in the digestive material, however, four tubes in each row were adulterated as follow: Second row, quantity equal to 9 drops of a 40 per cent solution of formal. dehyde for each gallon of milk, and decreasing the per cent in each row until the last had an amount equal to one drop per gallon.

The first effect noted was that the coagulation which normally occurs in milk upon the arldition of "remnin" in the ordinary commercial pepsin, was slightly retarded, the retardation being directly proportionate to the amount of formaldeh yde used. When coagulation did oceur the coagulum was tough in proportion to the amount of formaldehyde present, proving to my satisfaction that the coagulum formed by the digestive juice in the presence of formaldehvile was an exceedingly tough one. Next, tubes were placed in an incubator, kept there at a temperature of $100^{\circ} \mathrm{F}$. for 8 hours and then examined. I give briefly the result without burdening with weights of undigested residue, etc: P'ure milk in all tubes, fully digested; where large amount s of formaldehyde were present alsolutely no digestion. When the amount of formaldehyde present approached three drops to the gallon, digestion commenced and gradually increased as the porportion of the preservative decreased, but in the presence of one drop to the gallon the inhibitory action upon digrestion could be seen. 
Fort Wayne. (Population, 45, 115.)

[For comparison with other eities in Class III, see p. 34.]

L. Park Drayer, city sanitarian.

The daily consumption of milk is estimated as 2,480 gallons, or an average of 0.44 pint per eapita. Milk is sold from 15 stores and 106 wagons. Within the city lianits there are 297 cows in 175 stables, and milk is brought to the rity in wagons from 8.1 dairy farms, the longest haul being 8 miles.

General ordinance No. 128 regulates the milk supply. License fee for the sale of milk or cream is \$1. The city bacteriologist is placed in charge of the milk division of the department of health. Adulterated, etc, milk or cream is prohibited. Buarding-house keepers, etr., furnishing milk or cream are subject to the provisions of this ordinance. The milk standard is 12 per cent solids, 3.5 per cent fat. Cream standarl is 18 per cent fat. Skimmed milk rontainers must be painted red and be plainly labeled. Buttermilk must be from pure milk or cream. It is the duty of an ofticer of the board of health to examine as often as necessary all stables where cows are kept.

Ordinance section regarding delivery of skimmed milk is given in Appentix I (p). $179)$.

During the past year 700 samples of milk were examined by the Babeock test; no bacteriologieal examinations were made; all the city herds and all the dairy farms were inspected.

Terre Haute. (Population, 36,673.)

[For comparison with other cities in Class III, see p. 34.]

\section{O. Elliott, city inspector.}

The daily wnmm tion of milk is estimaterl as 1,000 gallons, or 0.22 pint per capita, besides 40 gallons of skimmed milk and 30 gallons of eream. Milk is sold from 9 stores and 25 wagons. Fifty per cent of the dairies supply milk in glass bottles, filled at the farms. A lawe fuantity of milk is pasteurized, am the practice is ine reasing. Milk is retailed at 5 cents per quart throughout the year, the producers receiving $3 \frac{1}{2}$ cents. The milk from one "model dairy" near the city is sold regularly for 10 cents per quart. Thirty-four dairy farms send milk into the city. Only a very little milk is received by railway, the longest shipment being 30 miles.

About $\$ 1,200$ is expended annually in the supervision of the milk supply, one official giving his entire time to this work. During the past year 500 samples were examined by the ladometer and Babeock test and were terted for preservatives, and all the dairy farms were inspected.

\section{South Bend. (Population, 35,999.)}

[For comparison with other cities in Class III, see p. 31.]

C. M. Butterworth, commissioner of health.

The daily consmption of milk is entimated as 1,000 gallons, or 0.22 pint per cappita. Milk is sold from 35 wagons. About one-third of the milk is delivererl in glatsy loottles, filled at the producing farms. Nomilk in pasteurized. The retail prionof milk is 5 cents per quart in summer and 6 cents in winter. There are no "model dairies" near the city. There are no dairy herds within the eity limits. Milk is sent in from 25 dairy fams. About 2 per ent is received hy railway, the longest shipment heing 15 iniles.

During the past year 28 samples were tested for preservatives; no basteriological examinations were made, and no herds were inspected. 
Richmond. (Population, 18,226.)

[For comparison with other cities in Class IV, see p. 40.]

George G. Ferling, V. P. S., dairy inspector.

The daily consumption of milk is estimated as 1,250 gallons, or 0.55 pint per caputa. Milk is sold from alout 15 stores and 39 wagons, and one-third of it is delivered in glass buttles, filled at the farms. Milk is pasteurized at one dairy farm, lnut the practice is not increasing. The retail price is 5 cents per quart throughout the year. A few dairies near the city are conducted in a better manner than others, but receive no arlvance in price for their product. There are 4 herds, inchuliner tis cows, within the city limits, and milk is sent from 36 dairy farms, all within 6 miles of the city.

There is expended annually $\$ 150$ in the supervision of the milk supply, one ofticial griving a part of his time to this work. During the past year 38 samples of milk were examinesl by the Baberek test, all the eity herds were inswected monthiy, and all the dairy farms were inspected.

liecently there have heen more cleanly methods in dairies amb nore care in the colling of milk. Further improvenents, as given, include the proper cleaning of stables and cows, a pure water and food supply, and the lelivery of milk in bottles.

\section{IOWA.}

II. R. Wright, dairy commissioner, Des Moines, sucressor to H. P. Norton (1908). code of 1897 , title 1:2, chapter 13, sertions 2522 to 2525 , and title 24 , whapter 10 , sections 4989 to 4991 , refer to market milk. They are enfored by the State dairy commiswioner. City milk dealers and persons supplying them must ke'p fremises and utensils in hygienie condition and must report statisties to the dary commissimer. Fvery persom wing a milk tent shall ohtain certified glasware from the dairy commissioner. An agent may he placed in each city of over 10,000 inhabitants to collect and test milk samples. A permit to sell milk must be olotained for each wagon, lepot, or store; all permits expire every July 4 , and cost s1 anmually. The sale of impure or adulteratenl milk, or milk from a direased cow or one having nlcers or sores, or milk from a cow within fifteen days before or five days after parturition, is forhidden. No person shall keep cows for production of market milk or cream in an unhealthy place nor shatl knowingly give them food which produces impure milk, or feed them distilled ghoose or brewery waste in a state of fermentation, or any jutrefying or unhealthy substance. The milk standam is 1:as per cent solids, 3 per cent fat; cream standard, 15 per cent fat. Skimmed milk may be sold as such.

An amenhment (Feneral Acts, 1902, chapter 102, section 1), places a penalty on creameries, etc., which do not report statistics to the dairy commissioner.

Inspection is now enducted under the direction of the dairy commisioner in 14 cities. The work of the local inspectors consists entirely of an inspection as to sanitary conditions of milk and the wagons and cans used in its delivery, and the testing of milk and cream samples for fat content. During the last year ist store and wagron licenses to sell milk were issued, and about 12,000 tests of milk and cream were made by the commissioner's agents; a number of examinations for preservatives were marle. Work in 1900 was carried on under difliculties due to atverse court decisions which have since been reversed. The total time expended in their work by the 14 milk inspectors is equivalent to perhaps sixty days a month; they are paid $\$ 3$ per day for their services.

The form for application for milk license is shown in Appendix IV (p. 190). 
Des Moines. (Population, 62,139.)

[For comparison with other cities of Class II, see P. 30.]

B. P. Norton, State dairy commissioner.

The daily consumption of milk is estimated as 5,000 galloms, or 0.64 punt per capita. This is sold from 40 stores and 125 wagons. Ten jer cent of the milk is delivered in glass bottles, some of which are filled at the farms an 1 some in the city. No milk is pasteurized. The retail price of milk is 5 cents per quart throughout the year, producers receiving 2 cents per quart in summer and $2 \frac{1}{2}$ cents in winter. There are no "model dairies" in or near the city. There are 75 herds, including 1,000 cows, within the eity, and 100 dairy farms send milk into the city. A portion of the cream shipped by railway comes a distance of 40 miles.

The city has no milk ordinance and provides no specific fund for the supervision of its milk supply, this work being under State control with an appropriation of 8300. One State official gives eight hayw each month to this work. During the past year about 1,000 samples of milk were examined by the Babcock test; no bacteriological examinations were made.

Recently there has been a decrease in the use of preservatives in milk.

\section{Dubuque. (Population, 36,297.)}

[For comparison with other citıes in Class III, see 1. 31.]

B. P. Norton, State dairy commissioner.

The amount of milk sold daily is estimated as 1,425 gallons, or 0.31 pint per capita, besides 150 gallons of cream. The above estimate does not include the milk from cows kept by private families in the city. Milk is sold from 12 stores and 45 wagons. Very little milk is delivered in glass bottles, and none is pasteurized. The retail price is 5 cents per quart throughout the year, producers receiving 2 cents and $2 \frac{1}{2}$ cents in the two seasons. There are no dairies near the city conducted in an entirely satisfactory manner. The milk from 40 dairy farms is brought to the city in wagons, the longest haul being 10 miles.

The city expends nothing in the supervision of its milk supply. The State dairy commission expends annually about $\$ 144$, one oflicial giving four days of each month to this work. During the past year 5,000 samples of milk were examined by the Babcock test; none of the dairy farms were inspecterl.

\section{Davenport. (I'opulation, 35,254.)}

[For comparison with other cities in Class III, ree p. 34.]

\section{H. Preston, city physician.}

The daily consumption of milk is estimated as 1,400 gallons, or 0.32 pint per capita, besides 500 gallons of skimmed milk and 150 gallons of cream. Milk is sold from 3 stores and 64 wagons. - Glass bottles, filled at the farms, are used largely in the delivery of milk. Little if any milk is pasteurized. The retail price of milk is 5 cents jer quat throughout the year, the joroluers delivering their milk at the above price. Within the eity limits there are 14 herds, including 239 cows, and milk is brought in wagons from 52 dairy farms within a radius of 6 miles from the eity.

An ordinance, passed in December, 1896, refers to milk. Wach dairy and dairy herd must be inspected by an officer of the board of health previous to the issuing of a license for the sale of milk therefrom. The tuberculin test is authorizerl. Inspected animals are tagged.

Inring the past year sto6) (eity $\$ 40)$, state $\$ 200)$ was expenterl in the supervision of the milk supply. One milk and health inspector and one food and dairy inspector 
give a part of their time to this work. One thousand milk samples were examined by the Babcock test, and five samples by gravimetric analysis; no bacteriological examinations were made. All city herds and dairy farms were inspected twice. Although there is no "model dairy" near the city, it is stated that all dairies "are conducted with care under inspection."

Recently dairies have improved in cleanliness, and the use of lottles has increased. It is stated that the milk supply might be further improverl if (xamination of samples conld be made in distriet bacteriological and chemical laboratories established by the State.

\section{Sioux City. (Population, 33,111.)}

[For comparison with other cities in Class III, see p. 34.]

\section{O. P. MeCray, agent of the dairy commission.}

The daily consumption of milk is estimated as 4,500 gallons, or 1.09 pints per capita. Milk is sold from 10 stores and 46 wagons. Glass hottles, filled at the producing farms, are used to a limited extent in the delivery of milk, and this practice is increasing. No milk is pasteurized. The retail price of milk is 5 cents pere quart in summer and 6 cents in winter. There are no "model daries" near the city. Within the city limits there are 41 herds, including 610 cows, and milk is brought in wagons from dairy farms within 6 miles of the city.

The State expends annually about sitt in the supervision of the rity milk supply, one ofticial giving a part of his time to this work. During the past year tat) samples of milk were examined hy the Babeock test; no bacteriological examinations were made; none of the city herds were inspected.

\section{Council Bluffs. (Population, 25,802.)}

[For comparison with other cities in Class III, see p. 34.]

IV. A. Groneweg, city milk inspector.

The daily consumption of milk is estimated as 1,600 gallons, or 0.49 pint per capita, besicles 50 gallons of skimmed milk and 250 gallons of cream. Milk is sold from 6 stores and 31 wagons. Ahout one-half of the dealers use glass buttles for delivering milk; these are filled both on the farms and in the city, and their use is increasing. Nearly one-third of the milk is pastentized, but this practice is not increasing. The retail price of milk is 5 cents per quart in summer and 6 cents in winter, the producers receiving $2 \frac{1}{2}$ cents throughout the year. There are no "model dairies" near the rity. Within the city limits there are 2.2 herds, including 300 (nws, and milk is sent in from 5 (?) dairy farms. One-third of the total supply comes in by railway, the longest shipment being 7 miles.

One official of the State dairy commission gives a part of his time to the supervision of the milk supply. During the past year milk samples were collected and examined by the Babeock test three or four times every month; no bacteriological examinations were made; none of the dairy herds were inspected.

The greatert recent improvement has been in the increased use of grasis lottles, which are both convenient and cleanly. It is suggested that all herds, barns, dairy buildings, ete., should be inspected once each month, and that all milk and cream be delivered in bottles, or small cans, so as to aroid munecessary contamination by dust, ete.

\section{Cedar Rapids. (Population, 25,656.)}

[For comparison with other eities in Class III, see P. 34.]

J. W. Griffith, V. S., city milk inspector.

The daily consumption of milk is estimated as 1,500 gallons, or 0.47 pint per (eapita, hesides 400 gallons of skimmerl milk and 200 gallons of crean. Milk is sold 
from 35 stores and 40 wagons. Glass bottles, filled mostly at the farms, are used by one-half of the milkmen. Milk was pasteurized by one dealer, but, on account of the snall demand for it, the practice has heen discontinued. The retail price is $t$ to 5 cents per quart throughout the year, the producers receiving 2 to 3 cents in summer and 3 to 4 cents in winter. There is no dairy near the city which is conducted in an entirely satisfactory manmer. Within the eity limits there are 8 herds, including 200 cows. No milk is received by railway. The most distant source of supply is 12 miles from the city.

The city expents nothing for milk inspection work, this being done hy the State dairy commission, one official giving a part of his time to this work at a cost to the State of $\$ 150$. During the past year milk samples were examined by the Babcock test; no bacteriological examinations were made, and none of the dairy farms were inspected.

Recently the milk supply has improved, due to greater cleanliness at the producing farms. It is suggested that all milch cows be tested with tuberculin.

\section{Burlington. (Population, 23,201.)}

[For comparison with other eities in Class IV, see p. 40.]

W. C. Hummell, health officer and milk inspector.

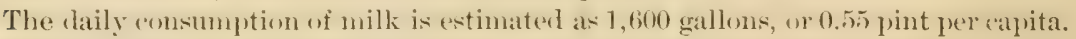
Milk is sold from 1 store and $4 t$ wagons. ()ne firm delivers milk in sterilizerl grlass bottles, which are filled in the eity. No milk is pasteurized. The retail price is 5 cents per quart in summer and 6 cents in winter. There are no "model dairies" near the city. Within the city limits there are 50 herds, including 1,200 cows. Milk is sent in from 12 dairy farms, the most distant being 20 miles from the city.

$A$ city ordnance gives the health oflicer power to prosecute under State law and to prohibit the sale of impure or adulterated milk.

Nothing is appropriated hy the aity for the supervision of its milk sulply, this work leing under State control. Ihuring the past year tovo sumples of milk were examined by the Babcock test; no bacteriological examinations were made; 35 of the 50 city herds, but none of the dairy farms, were inspected.

Needed improvements, as given, include thorough inspections of milk and dairies, such inspections to be made often until the character of the supply is satisfactory.

\section{Clinton. (Population, 22,698.)}

[For comparison with other cities in Class IV, see p. 40.]

B. P. Norton, State dairy commissioner.

The daily consmpution of milk is estimaterl as 1,000 gallons, or 0.35 pint per capita, besides to gallons of (eream. In explanation of this alplarently low ansmuntion it is staterl that many families keep their own cows and the milk from these is not

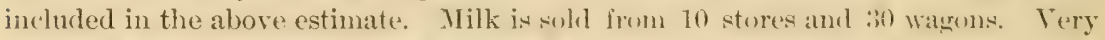
little milk is delivered in grass bottles, filled at the farms and in the rity; none is pasteurized. The retail price is 5 cents per quart throughout the year, producers receiving 2 cents in summer and $2 \frac{1}{2}$ cents in winter. There are no so-called "model dairies" near the city. Milk is sent in from 30 dairy farms, the most distant being 10 miles from the eity.

The city milk supply is under State supervision. During the past year 4,000 samples of milk were examined by the Babeock test.

Recent improvement is due to the decreased use of preservatives. 
Ottumwa. (Population, 18,197.)

[For comparison with other cities in Chass IV, see p. 40.]

E. B. Hill, milk agent.

The daily consumption of milk is estinnated as tok gallons, or 0.27 pint per capita, hesides 15 gallons of skimmed milk and 12 gallons of cream. In explanation of this small consumption, it is stated that there are 200 cows kept by private families in the city, and the milk from these is not inelueder in the above estimate. Milk is sold from 1 store and 18 wagons. Only a few bottles are used in the delivery of milk, and these are filled at the farms. No milk is pasteurized. The retail price is 5 cents per quart in summer and 6 cents in winter, producers receiving $2 \frac{1}{2}$ cents and 3 cents in the two seasons. There are no so-called "model dairies" near the city. Within the eity there is one herd (12) (ows), amd milk is sent in from 20) dairy farms within a radius of 10 miles. About 8 per cent is received by railway.

During the past year 576 samples of milk were examined by the Babcock test; 1 bateriological examination for typhoid hacilli; 1 of the 20 dairy farms was inspected.

Keokuk. (Population, 14,641.)

[For eomparison with other eities in Class IV, see p. 40.]

Frank Harshman, deputy state dairy commissioner.

The daily consumption of milk is estimated as 500 gallons, or 0.27 pint per capita, bexides:30 gallens of skimmerl milk and 50 gallens of aream. Milk is sold from :0 stores and restaurants and 16 wagons. Glass bottles are not used, and no milk is pasteurized. The retail price is 5 cents per quart in summer and $6 \frac{1}{4}$ cents in winter, producers receiving 4 and 5 cents in the two seasons. There are no "model dairies" near the city. About 500 cows in the city and on 16 dairy farms produce the milk supply. The most distant dairy farm is 4 miles from the city.

About $\$ 126$ is expended annually as the salary of one State official, who gives a part of his time to this work. During the past year 432 samples of milk were examinerl hy the Babcock test; no hacteriological examinations were mate; all city cows and all dairy farms were inspected.

Recent improvement in the milk supply is due to a better crrate of cows and more careful feeding.

It is stated that milk should be delivered in bottles filled at the farms.

\section{Marshalltown. (Population, 11,5t4.)}

[For comparison with other cities in Class IV, see p. 40.]

E. M. Singleton, M. D., city milk inspector.

The daily comsumption of milk is estimated ats 800 galloms, or 0.55 print jeer capita, hexides 100 gallons of skimmed milk and 20 grallons of eream. Milk is sold from 1 store and $1+$ wagons, and about one-half of it is delivered in glass bottess filied at the farms; none is pasteurized. The retail price is + to 5 cents per puart in smmmer and 5 to 6 cents in winter, producers receiving $2 \frac{1}{2}$ cents per quart. There are no "model dairies" near the city. Within the city there are 2 herds, including 35 cows, and milk is sent in from 12 dairy farms within a radius of 3 miles.

About $\$ 110$ is expended annually in the supervision of the milk supply as the salary of one State official, who gives a part of his time to this work. During the past year 500 samples of milk were examined by the Babcock test.

It is stated that dairies should be mepecterl, and that cleanly methods be required. 


\section{KANSAS.}

General Statutes, 1897 , volume 2, sections :222 to:3:31, refer to milk and food. The salle of alulteraterl and skimmerl milk with intent to defraur, or the sale (knowingly) of the product of discasest animals, is forbirlilen. It is unlawful to sell food which is adulterated, this term being defined at length.

\section{Kansas City. (Population, 51,418.)}

[For comparison with other cities of Class II, see P. 30. See also Kansas City, Mo.]

Jacob S. Heisey, inspector of licenses, weights, measures, and milk.

The daily comsumption of milk is estimated as 3,000 gallons, or 0.47 pint per capita, besidtes 16ij gallons of (ream. In addition to the aloove, 4,000 gallons of milk is used daily by six oleomargarine manufacturers. Milk is sold from 100 stores and 75 wagons. Glass bottles are not used in delivering milk. During the summer months fully 80 per cent of the milk is pasteurized. The retail price of milk is 5 cents per quart throughout the year. There are no "model daries" in this vicinity. Within the city limits there are 42 herds, including 1,000 head of cattle. A part of the city milk supply comes 40 miles by railway.

()rdinance No. :3:20), August, 1899, refers to milk. P'ersoms selling milk must have permit. Adulterated, discased, ete, nilk is prohibiterl. Inspector must inspect all dairies and lairy "ows within the eity limits during the months of $\lambda_{\text {pril }}$ and October, and he may inspert dairies beyond the eity limits on payment of 82 each and is cents per mile. The milk standard is 12 per cent solids, 3 per cent fat. Condensed milk, buttermilk, sour milk, or skimmerl milk must be properly labeled and be from pure, wholesome milk.

Besides expenses borne by the license department, about $\$ 100$ is paid each year to a veterinary surgeon for assistance in examining herds. No milk samples were examined during the past year, but all the city herds and 10 dairy farms were inspected.

The form for notice which must be sent to the inspector when cows are added to a dairy herd is shown in Appendix IV (p. 199).

Recent improvement has been made in the quality of milk by the introduction of cows producing rich milk.

Topeka. (Population, 33,608.)

[For comparison with other eities in Class III, see p. 31.]

J. P. Farnsworth, eity food inspector.

The daily consumption of milk is estimated as 2,000 gallons, or 0.48 pint per atpita, besides 50 gallons of skimmed milk and 80 gallons of cream. This is sold from 20 stores and 50 wagons. Five per cent of the milk is delivered in glass bottles, which are filled in the city; none is pasteurized. The retail price is 5 cents per quart in summer and 5 to $6 \frac{1}{4}$ cents in winter, producers receiving $2 \frac{1}{2}$ cents in summer and $2 \frac{1}{2}$ to $3 \frac{1}{8}$ cents in winter. The milk from one "model dairy" near the city is sold for s! cents per quart and higher. Within the city limits there are 4 herds, including 60 cows, and milk is brought to the eity in wagons from 150 dairy farms within a radius of 10 miles.

Ordinances No. 620, of May, 1886, and No. 802, of April, 1888, refer to milk. The forel inspertor (salary sogo) must inspect the milk supply. Persons selling milk most register with the board of health. Adulterated, etr., milk is jmohibiterl. Nilk from cous fed on refue from stareh factory, vinexar factory, or grlucuse factory is prohibited. The milk standard is 12 per cent wolids, 3 per cent fat. Skimmed milk must be labeled. 
About $\$ 1,000$ is expended annually in the supervision of fooks, the inspector giving a part of his time to the milk supply. During the past year about too samples of milk were examined by the Babonck test; no hacteriological examinations were made; all the city herds and nearly all the dairy farms were inspected.

It is stated that the milk supply would be very much improved if producers would not aerate their milk in or near barns.

\section{KENTUCKY.}

Acts of 1891, 1892, and 1893, chapter 182, section 144, refer to milk. It is unlawful to knowingly sell milk that is arlulterated, or from at diseasest cow or from a cow ferl upon still slop, brewers' slop, or brewerw' grains. Skimmed milk shall not he sold with intent to defraud.

Acts of 1900 , chapter 13 , refers to foods. It forbids the sale of a food which is adulterated or contains an antiseptic or preservative, unless same is branded "adulteraterl," and sild for what it is. The State agricultural experiment station may inspect and analyze fools, adulterated products to be reported to the Commonwealth attorney of the clistrict, or county attorney, or city attorney for lrosecutions. The director of the asrienltural experiment station is (mmpwered to fix standarls of purity, ete.,

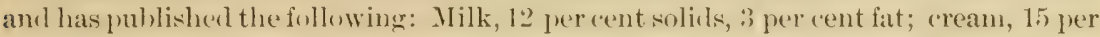
cent fat; both of these to be free from yreservatives or coloring matter.

Louisville. (Population, 204,731.)

[For comparison with other cities in Class I, see p. 26.]

- M. K. Allen, M. D., health ofticer.

The daily consumption of milk is estimated as 10,000 gallons, or 0.39 pint per capita, hesides 8,000 gallons of skimmerl milk amel 50 gallons of cream. Milk is sold from 100 stores and 250 wagons. Possibly one-fourth of the milk is delivered in glass hottles, which are fillexl on the producing farms. (Mnly a small amount of milk is pasteurized, but the practice is increasing. The retail price of milk is 5 to 6 if cents per quart throughout the year, producers receiving :3 (ents per quart in summer and 32 cents in winter. There are three or four especially well-conducted dairies near the city which retail their product as high as $7 \frac{1}{2}$ cents per quart. Within the city limits there are about 100 heris, including 1,000 cows. There are also about 100 dairy farms sending milk into the eity. It is estimated that one-half of the total milk supply is shipped by railway, the longest shipment being 50 miles.

Orlinance No. 108, series 1898 , adopted in May, regulates the milk supply. Wach person semeling milk into the city must have a permit from the health oflicer, granter in January of each year, free of charge. Permit numbers must be shown on wagons, aud names of tairymen supplying milk must be shown in stores, etc., where it is sold. Permit holders must furnish, once every three months, a certificate from a veterinarian to the effect that all his milch cows are free from disease. The tuberculin test may he required in any herd suspected of infertion with tuberculosis. Wach cow must have 600 eubic feet air space, and all dairy buildings must be well constructed and painted or whitewasherl. The standard for milk is 12 per cent milk solids, 3 per cent fat, and a specific gravity not less than 1.029 ; cream must contain 20 per cent of butter fat. The sale of unwholesome or artulterated milk is prohibited, including milk from cows within fifteen days before or ten days after calving, from cows fed on distillery waste or any fermenting substance or given any unwholesome food or drink, or from eows kept in a crowderl or unhealthy endition, milk from which any part of the erean has been removerl, and milk to which any foreign substance has been added. Skimmed milk may be sold, if plainly babelert, and if it contains the normal amount of casein and salts. Bottled milk must not be delivered to, nor empty bottles taken from, any dwelling where there is a contagious 
disease, and no person who has heen exposed to at contagious diseame shall work in at dairy. Dairy employees must maintain strict cleanliness. Manure must be removen twice daily, one hour preceding each milking. The teats and, if necessary, the ndders must le carefully cleaned before milking. All apparatus usert in handling milk must be of nonabsorbent material and be kept clean at all times. When milk vessels are filled they shall be promptly removed from the stable and not sturerd in a rom where animals are kept. The health officer must be notified within twentyfour hours after the discovery of a contagious or infections direase anong the cuws. Diseased cows must be isolated.

The full text of the milk ordinance is shown in Appendix I (p. 169).

The city does not provide a specific fund for the supervision of the milk supply. Three sanitary inspectors of the health department ocasionally give attention io this part of the food supply. During the past year 475 samples of milk were analyzed, and about 25 of the 100 eity herds and 25 of the 100 dairy farms were inspected; no bacteriological examinations were made.

Marked improvement has been made in the sanitary condition of the dairies. Further needs, as given, include close attention to the sanitary condition of the dairies, the use of the tuberoulin test, and hacteriologieal examinations of the milk.

Covington. (Population, 42,938.)

[For comparison with other cities in Class III, see p. 34.]

Charles W. Reynolds, health officer.

The daily consumption of milk is estimated as 3,500 gallons, or 0.65 pint per capita. This is sold from 140 stores and 36 wagons. Two firms deliver milk in glass loottles, these being filled at the producing farms. The same firms jasteurize milk and the demand for milk so treated is increasing. Milk is retailed at 6 to 8 cents per quart throughout the year; the milk from one "model dairy" is sold regularly at 8 cents. There are no dairy herds within the city limits. Milk is sent in from 31 dairy farms, all within 9 miles of the eity.

During the past year 372 samples of milk were examined by the lactometer and Babcock test; no hacteriological examinations were nade; all the dairy farms were inspected.

Newport. (Population, 28,301.)

No reply to inquiries was received.

Lexington. (Population, 26,369.)

[For eomparison with other cities in Class III, see p. 34.]

F. O. Young, M. D., president of the board of health.

The daily consumption of milk is estimated as 2,000 gallons, or 0.61 pint per capita, hesides 258 gallons of skimmed milk and 178 gallons of cream. Milk is sold from 10 stores and 48 wagons. Ninety per cent of the milk is delivered in glass loottles filled at the farms. Abont one-third of the supply is pasteurized, and this matetice is increasing. The retail price of milk is 5 cents per quart in summer and (i) rents in winter, producers receiving $3 \frac{1}{8}$ rents and 33 cents, respectively. ILilk is brought to the eity in wagens from 39 dairy farms, the lomgent hatul being 7 miles.

The rity has mo milk ordinance and exercises no supervision over its milk supply.

\section{LOUISIANA.}

A ('ts of 18s:2, No. 82, refers to foods. It forbids the sale of adulterated forid, which term is defines at length. It is the duty of the state board of health to investigate foods. 


\section{MILK SUPPLY OF TWO HUNDRED CITIES.}

New Orleans. (Population, 287,104.)

[For comparison with other cities in Class I, see p. 26. ]

Quitman Kolnnke, M. D., health officer.

The daily ('manuption of milk is estimated as 9,609 gallons, or 0.27 pint per capita, besilfes 200 grallons of skimmerl milk and 75 gallons of (ream. Milk is distributed from 17 stores and 410 wagons. A few venters use grlass bottles in their trade. A small amomt of milk is pasteurized, and this treatment is increasing in favor. The retail price of milk is $7_{2}$ eents per quart both in summer and winter, producers receiving 23 cents. There are 3 "molel dairies" in the vicinity which sell their product for 10 cents per quart during the entire year. There are 440 dairy herls, including 6,685 cows, within the eity limits, producing 86 per cent of the total supply, and 69 dairy farms send milk into the city, the longest shipment being $8: 3$ miles.

Several city orlinances relate to the milk supply. The principal one appears to be No. 1620-t, arlopterl in IIay, 1890; others are 4627 of 1890, 6596 of 1892, and 7581 of 1893. It is required that a permit be ohtained for the production or sale of milk or other dairy product to be userl as food in the city. This is issued by the board of health, free of charge, and only after certain detailed information regarding the source of the milk and the conduct of the proposed business has been filed; it is revocable for cause. Permit number am name of supplying dairy, ete., must appear on delivery wagons. The reguirements for dairy stables and milk rooms are given in considerable rletail, some of them being that all dairy buildings must be constructed in a sanitary mamer, properly equipperl, and well cared for; 600 cubic feet of air space must be allowed for each animal; milk appliances must be of nonabsorbent material; milk cans must he removed from the stable promptly when filled and be thoroughly scalded when cleanet; refrigerators must be constructed and located in a particular manner; milk must not he storerl in a room where animals are kept; bottles must not bedelivered to nor taken from any place where there is a contagious disease; bottles must not be filled on delivery wagons; stock must not he given impure water, nor ferl on hrewery grain or other unhealthy fool; cows must be rejected if diseased and the tubereulin test must be userl in their examination; healthy cows must be taggenl; employees must be perwonally cleanly and healthy and not recently exposed to disease. The nilk standard is 13 per cent solids, 9! per cent solids not fat, $31 \frac{1}{2}$ per cent fat; specific gravity, at $60^{\circ} \mathrm{F}, 1.029$. Adulterated milk, milk to which any foreign substance has been adrerl, or milk from unhealthy cows is prohibited. Skimmed milk may he sold if in plainly labeled ressels. To liquirl other than milk or cream shall be carried in a milk wagon.

The supervision of the milk supply is included in the work of the food inspection department and its expense to the city is not kept separately. In the department named there is one chief (a veterinarian), whose salary is $\$ 1,500$, and 13 assistants paid $\$ 600$ each. These officers inspect dairies and collect milk samples for the chemist, whose salary is $\$ 1,300$. During the past year 1,141 samples of milk were examined by the Babcock test, pycnometer, or gravimetrically; 2 bacteriological examinations were made for tubercle bacilli; all the dairy herds within the city and 27 of the 69 dairy farms were inspected.

Milk "runs" are made at freruent irregular intervals. The officer is supplied with a known number of hottles with perforatel necks and the same number of perforater learl seals, also short wires and a clamp. Samples must be sealed in the presence of the render. The number of lead seals used and unnsed are checks on each other. The lead seals may be marked by venders if desired. (This method is explained here in detail because it differs from the one usually practiced by which samples are taken in duplicate, one being leit with the vender for analysis or disposition as he chooses.)

It is sairl the average quality of the milk sold in the eity has recently shown marked improvement.

$25839-$ No. $46-03-6$ 


\section{MAINE.}

Revised Statutes of 1883 , chapter 38 , sections 44 to 47 , amended in 1857,1893 , and 1897, and Public Laws of 1895 , chapter 144 , section 1, refer to milk. Milk inspectors shall be appointed in towns of more than 3,000 inhabitants, and may be appointed in smaller towns. They are required to keep a record of the names and addresses of all milk dealers, and may inspect places and vehicles where milk is sold and take samples for analysis. It is unlawful knowingly to sell milk from cows having tuberculowis or other lisease or fed upon the refuse of breweries or distilleries or other deleterious sulstance, or milk to which water or any foreign substance has heen adderl. The milk standard is 12 per cent solids, 3 per cent fat. Skimmed milk must not be sold for pure milk. Milk must be sold by wine measure, and measures must be sealed anmually.

Public Laws of 1895 -chapter 169 requires that milk tests, for basis of payments, shall be accurate.

\section{Portland. (Population, 50,145.)}

[For comparison with other cities in Class II, see p. 30.]

\section{W. C. G. Carney, health inspector.}

The daily ensumption of milk is estimated as 3,000 gallons, or 0.48 pint per eapita. Milk is sold from 200 stores and 75 wagoms. About one-fourth of the milk is delivered in wlass hottles which are filled in the city. Little or no milk is pasteurized. The retail price of milk is 6 cents per quart in summer and 7 cents in winter, producers receiving 3 cents in summer and 4 cents in winter. $A$ few dairies near the city, better comlucted than others, receive a slight increase in price for their product. Within the city limits there are 19 herds of milch cows, including 13 thearl, and nilk is sent into the cidy from to dairy farms. About three-fourths of the total uilk supply is received by railway, the longest shipment being 48 miles.

The city has no milk ordinance and expends nothing in the supervision of its milk supply, therefore no inspection work has been done.

\section{Lewiston. (Population, 23,761.)}

[For comparison with other cities in Class IV, see p. 40.]

James H. Goddard, milk inspector.

The daily consumption of milk is estimated as 1,800 gallons, or 0.61 pint per capita. Nilk is sold from 10 stores and 75 wagons. Glass bottles, used only to a small extent, are filled at the farms. About 500 gallons are pastemized daily; the pratice is not increasing. The retail price is 6 cents per quart throughout the rear, the producers receiving 3 cents. There are no "model dairies" near the city. Within the city limits there are 25 herds, and milk is sent in from 50 dairy farms within a radius of 5 miles.

State statutes regulate the sale of milk.

thont 8200 is expended annually in the supervision of the milk supply, one oflicial giving a part of his time to this work. During the past year alhout :ato milk samples were exanined by gravimetric analysis; no hacteriological examinations were made; 15 city herds and 10 of the 50 dairy farms were inspected.

\section{Waterville. (Population, 9,477.)}

[For eomparison with other cities in Class IV, see p. 40.]

A. Joly, D. V. S., milk inspector.

The daily consumption of milk is estimated as so0 gallons, or 0 . 6 s pint per eapita, heides 100 gallons of skimmed milk amb 50 gallons of eream. Milk is sold from 15 
stores and 39 wagons, and a number of private families sell milk to their neighbors. About 75 per cent of the supply is delivered in glass bottles filled at the farms; mone is pasteurized. The retail price is 5 cents per yuart in summer and 6 cents in winter. There are four dairies conducter on a considerably better plan than others, but they receive no advance in price for their product. Within the city limits there are 8 herds, including 75 cows, and milk is brought in wagons from 39 dairy farms, the longest haul being 8 miles.

State laws regulate the sale of milk.

One humberd dollars is expented annually in the supervision of the milk supply, one official giving a part of his time to this work. During the past year 160 samples of milk were exanined by the lactometer and Babeock test; no hacteriological examinations were made; all the city herds and all the dairy farns were inspected.

The milk inspector's report for 1899 shows that out of 201 samples exanined 7 were found to be below the standarl, and these were from grocery stores where the milk was not mixed before sales. Thirty-four dairies were inspected, the inspection consisting of a physical examination of each cow and an examination of the water supply, lrainage, rentilation, etr. Two herds were tested with tuberculin and found to be free from tuberculosis.

Recent improvement in the milk supply is due to better hatns, cows, and sanitary conditions.

\section{Belfast. (Population 4,615.)}

[For comparison with other eities in Class IV, see p. 40.]

IV. L. West, M. D., milk inspector.

The daily consumption of milk is estimaterl as 300 galloms, or 0.52 pint per capita, besides 20 gallons of skimmed milk and 5 gallons of eream. Milk is sold from 6 stores and 12 wagous. Ahont one-half of it is delivered in grass bottles, filled at the forms, and the portion thus served is increasing. No milk is pastemized except hy

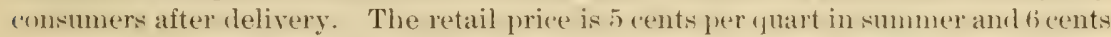
in winter. There are no "model dairies" near the city. Within the city limits there are 5 herds, including 125 cows, and milk is brought in wagons from 30 dairy farms, the longest haul being 8 miles.

Ahout 850 in expended by the city in the supervision of its milk sulply, one official giving a part of his time to this work. During the past year 150 samples of milk were camined ly lactometer, Babeock test, and gravimetric analysis; no bateriological examinations were made; each dairy farm was inspected every month.

Recent improvement is shown in the feeding of cows and the handling of milk. Needed improvements, as given, include the testing of all cows with tuberculin; compelling milk to be delivered in glass lottles, and the dissemination of information regarding the care and handling of milk.

\section{MARYLAND.}

Laws of 1894 - chapter 533 refers to milk. The mayor and city council of Baltimore shall make regulations for the sale and provide hy ordinance for the inspection of milk and food products; shall provide for and fix compensation of inspectors and analysts.

Laws of 1895 - hapter 306 refers to rattle and dairies. Cow producing market milk shall he registered with the live stock sanitary hoard, and a certificate of health may be furnished for a herd which is kept as the law reduiress and has no visible sign of disease. Said boarl must inspect at least annually premises where cows are kept and enforce rules requiring buildings to be sanitary, well lighted and rentilated, clean, and painted or whitewashed; cows to be clean, properly fed, and watered; milk vessels to be clean, etc. 
Laws of 1890 - chapter 604 , sections 52 to 56 , refer to milk and food. Direased or unwholesome milk must not be sold. The state board of health is given power to enforce.

Laws of $1900-$-supplement, article 27 , parge 40 , refers to milk and food. The milk standard is 12.5 per cent total solids, 3.5 per cent fat. The sale of alulterated milk, milk to which any foreign substance has been added, milk from diseased cows, and milk from cows fifteen days before or five days after barturition. Skimmed milk mat be sold if properly labeled. Condensed milk must be from pure milk of standard quality.

\section{Baltimore. (Population, 508,957.)}

[For comparison with other cities in Class I, see p. 26.]

G. W. Lehmann, chemist of health department.

Estimated average ammunt of milk uwert daily is 25,000 gallons, or 0.39 pint per (alpita; skimmed milk, 5,000 gallons; (ream, 4,000 gallons. Milk is distrilonted from $2,5,30$ stores and 525 wagons. In its delivery glass jars are used by abuut twenty different concerns, only one of which brings the milk in them from the country. Pastemized milk is used very little and is not increasing in faror. The retail price of milk is 5 to 10 cents per quart, the producers on the farms being paid 3 to 4 cents. There are three "model dairies" near the city and their milk is sold at 8 to 10 cents per quart. Within the eity limits there are 3,314 cows in 539 stables and sheds. About 1,500 dairy farms send milk into the city, some of them from a distance of 200 miles.

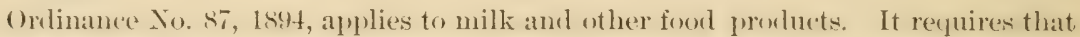
milk sold shall be the natural product of healthy cows, from which no cream has been removed and to which no liquid, solid, or preservative has been added; it shall contain 3 per cent fat and 12 per cent total solids, and at $60^{\circ} \mathrm{F}$. have a specific gravity of at least 1.029. Skimmed milk or buttermilk may besold if purehaser is andvised of its character. The board of health enforces the ordinance and is authorized to make additional rules. ()rdinance No. 130, 18:4, provides for prompt confication of milk for violation.

The city expends annually about $\$ 2,300$ in the supervision of the milk supply. Two inspectors give their entire time and one chemist part of his time to this work. The year's work in 1900 included the examination of 31,803 lots of milk, aggregating 1, 166, stitigallons, of which 11,226 gallons were spilled beratuse whown hy the lactometer or general appearance to be below the legal standard. The loss of his milk is pratioally the only penalty suffered by the offender; no arrests are made, on account of difliculty of foreceution before police justices. During the year $900 \mathrm{milk}$ samples were examined for fat content by the centrifugal test and in a few cases by gravimetric analysis. The average of the analyses of ts miscellaneous sampley of milk taken during the twelve months, and which were considered good, showed total solids 13.96 per cent; fat, 4.58 per cent. It is suggested that some dealers nee preservatives and some skillfully alter their milk with the aid of the lactometer, taking eare not to bring it below the reguired standard. About 300 samples of milk have been examined microscopically or bacteriologically for tuberele bacilli, pus rells, ete. An interesting study was made along this line: Milk from 11 dairy farms, after its arrival in the city, was found to contain from 5,160 to $: 3,3,200$ bacteria per cubic centimeter, 0 to 1.4 pus cells, and no tubercle bacilli. The clarifying of milk by means of a separator was not found to reduce its bacterial content. The milk of 11 unsanitary dairies near the city limits was found in all cases to have pus cells, varying in number from 0.1 to 9.5 per cubie centimeter, and tubercle bacilli were found in the milk of 3 of these dairies. Stables within the city limits and the sanitary condition of the stock are frequently inspected by a veterinarian. In one recent year the city inspector of cow stables issued over 1,100 notices to abate nui- 
sances. Two hundred and twenty of the 1,500 dairy farms sending milk into the city have heen inspected under the direction of the Ntate live-stock sanitary hoard.

The form to be attached to a can from which milk has been spilled is shown in Appendix IV (p. 206).

There has recently been noticeable improvement in the guality of milk and the cleanliness of dairy stables, and increased care has been taken to exclucle diseased animals from dairy herds. Suggested improvements include a standard of 13 per cent total solids and $t$ per cent fat, and more milk insuectors and legislation to compel all milk shippers to submit to the regulations of the local health department.

\section{MASSACHUSETTS.}

\section{George M. Whitaker, agent of State dairy bureau, Boston.}

Acts of 1901 , chapters 202 and 360 ; 1900 , chapters $300,359,368$, and 369 ; and 1891 , chapter 412 , sections 7 to 11 , provide for the protection of dairymen, sealing of glass bottles and measures, enforement of State dairy laws hy the dairy hurean, and refer to adulteration of milk and destruction of milk vessels. P'ublic statutes, chapter 57 , sections 1 to 11 , amenderl; and acts of 1899 , chapter 169 , section 1; 1896 , chapter 264 , sections 1 and 2 ; 1894 , whapter 425 , section 1 ; 1889 , chapter :22ti, section 1 ; 1886 , chapter :318, sections 3 and 4 , amended; and 18 s.5, chapter 35.2 , section 8 , refer to milk, milk inspectors, etc.

The dairy burean is empowered to investigate all dairy products. The mayor and alclermen of eifies shall, amb the selectmen of towns may, appoint milk inspectors. (Under authority of other acts the milk inspectors of Boston, Lymn, and somerville. are appointed hy the hoards of health of those cities.) P'eroms pedlling milk in rities or towns having nilk inspectors must be licensed annully in May; fee, 50 cents. License number and place of business must be shown on wagons, ete, and all whanges of employees must be reported. Persons selling milk from stores, ete., munt he registered; fee, 50 cent. Dealers in milk or cream may register in the office of the clerk of the city or town brands for bottles, cans, etc., including the mord "registered," and "anse the same to be published, and the use or destruction of such resiels or mutilation or destruction of marks thereon by other parties than the owner is prohibited, and it is unlawful to put into such ressels any unclean or foul sulstance or matter. Inspectors may visit places where milk is sold and take samples for analysin. Duplicate simples must be given to owners when requested and report of analysis must be sent to them within ten days. It is unlawful to sell milk not of good standaril quality, or adulterated milk, or milk to which water or any foredion sulstame has heen arliked, or milk from cows diseased or fed upon the refuse of distilleries; and it is unlawful knowingly to feed garbage to a milch cow. The milk standard, October to March, is 9.3 per cent solids not fat, 3.7 per cent fat; April to Sieptember, 9 per cent solids not fat, 3 per cent fat. Skimmesl milk must be plainly marked; its standard is 9.3 per cent solids not fat. Cans, bottles, etc., of specified capacities used for distribution of milk or cream shall be sealed as measures. Cilassware, etc., used in terts shall be tested for accuracy and marked hy the director of the IIatch experiment station, and once each year he shall test "entrifugal machines user in such tests. Milk tests must be accurate, and persons manipulating them shall hold a certificate of competency from said director. Said director whall test by the Babcock methor samples of milk or cream for farmers, creameries, firctories, or milk depots, the charge heing for actual cost. Convictions for selling arlulterated milk nust be advertised in newspapers. Condensed milk must he labeled with the name of manufacturer; if in hermetically sealed packages, brand and contents must also be shown.

The State board of health does more than the dairy bureau in the supervision of the milk supply of cities. Very few sanitary inspections are made. The dairy 
bureau has no jurisdiction over local milk inspectors, but has broader power and to a limited extent cooperates with them. In most cities the chief work of the milk inspector consists of issuing licenses and keeping a record of certain statistical and other general information. In many cases their compensation is merely nominal.

In several cities and towns the State laws relating to the milk supply are published and distributed by local authorities.

\section{Boston.a (Population, 560,892.)}

[For comparison with other eities in Class I, see p. 26.]

Charles Harrington, M. D., inspector of milk.

Alexandire Burr, health department.

The daily receipts of milk are estimated at 82,250 gallons, or 1.17 pints per capita. In explanation of this apparently large per capita consmuption, the inspector of milk states that a very large anount of milk is consumed each day at the quick-lunch places and elsewhere ly the several thousand persons who live in neishboring cities and town but speme the business hours in Boston. A single luneh room uses as high as 640 quarts daily. The milk supply is practically controlled by a few large contractors, who operate cars on the different railrads. The contractors will not sell skimmed milk. It is impractieahle to estimate the amount of cream need, ats a conwiderable part of it is shimped by express to retailers. Milk is sold in about 2,900 stores; the number of wagons employed in its delivery is not known. Licenses for the sale, ete, of milk have been issued to the number of 506 . Some licensees do not operate wagons, while others may rum as many as 30. It appears that milk stores from which the milk is not perldled are not required to have a lieense, but simply a permit. Glass bottles filled in the city are quite extensively used for delivering milk; they are used but little in its transportation. Very little pasteurized milk is on the market, and it is not inereasing in favor. The retail price of milk is from 5 to 8 cents per quart (32 fluid ounces) in summer and winter, and the producers are paid about 3 cents per quart in summer and 4 cents in winter. There are about 20 well-conducted dairies in the vicinity of Boston, but, with one or two exceptions, they receive no advance in price for their product. Within the city limits there are 126 dairy herk, including 739 hearl. The number of dairies sending milk into the rity is not known; 75 per cent of the milk supply is receiverl by railway, the longest shipment being 140 miles.

The regulations for the sale and care of milk adopted in December, 189s, are publisherl in circular No. \& of the hoard of health. Five sections of regulations arlopted in 1892 appear to be also in force. Persons selling milk must obtain a license from the board of health annually, in May; it is revocable for cause. A statement of the conditions under which each cow is kept must be filed with the inspector of milk. No milk shall be sold from cows that have not, within one year, been exanined and found to be free from dangerous disease. The tubereulin test is not required. License must be posted in a conspicuons place on premises, and wagons must bear owner's name and license number. 111 cans and ressels used in handling milk must. be cleaned or sterilized before use, nor shall they be used for any other purpose. Rooms in which milk is stored, cooled, or mixed must have tight walls and floors and be kept clean, and must have proper appliances for washing or sterilizing all dairy utensils with boiling water or steam. Such room must not bes connected with water-clowet, urinal, etc., nor be used for stabling animals, nor shall milk be stored in a room used for domestic or sleeping purposes. Milk in stores, restaurants, etc., must be kept in a covered box or refrigerator properly drained and cared for.

"The milk supply of Boston is discussed at length in Bulletin No. 20, Bureau of Animal Industry. 
Every person engaged in handling milk must notify the board of health and stop the sale of milk when an infections disease is discovered in his family or among his employees. All vessely handled by persons suffering from such diseases shall be thoroughly sterilized hefore being used to hold milk. Cow stahles must have at least 1,000 cubic feet air space for each aninal, be well lighterl and ventilater, have tight roof and floors, be well drained, have a pure water supply, and he kept clean. Pastures must be clean.

A copy of the instructions sent out by an enterprising Boston milk contractor to the dairgmen from whom his milk is obtained is shown in Appendix II (p. 181).

Ahout 813,000 is expended annually in the supervision of the city milk supply. An inspector, a chemist, a clerk, and three collectors of samples give their entire time to this work. During the past year about 15,000 samples of milk were examincel hy lactometer and lactoscope, the Baborck test, and gravimetric analysis, all of them heing tested for preservatives; no hacteriological examinations were made; all of the city herds, and "many humbeds" of the dairy farms sending milk into the city, were inspected. A letailed description of the method of procuring samples of milk for inspection is given on page 22 .

The form for application to sell milk is shown in Appendix IV (p. 195).

The form for reporting conditions at dairies is shown in Appendix IV (p. 196).

The form for license to sell milk, receipt, and stub for sime, are shown in Apuendix IV (p. 202).

Iiecent marked improvement has been made in the sanitary quality of the milk suphly. Sugrested improvements include the erlueation of those who use milk, as well as those who promber it. The consumer wants his milk delivered early in the morning and insists that it must be fresh. He will not deal with one who would propose to deliver as late as 10 c'clock a. m., which is about the time the milk trains arrive. So the dealer is obligerl to hold the milk, perhaps in his stable, through the day and over one night, in order that it may be delivered early in the morning.

Worcester. (Population, 118,421.)

[For comparison with other cities in Class I, see p. 26.]

\section{Herbert De Fosse, inspector of milk.}

The milk inspector's recorls show that there are received in the city daily about 16,500 gallons milk, 200 gallons skimmed milk, 250 galloms cream, and 400 cans of condensed milk. It would appear from these figures that the average consmution of milk is 1.1 pints per capita. But it is somewhat less than this, for the reason that considerable milk, cream, etc., is sent from Worcester to smaller towns within a radius of 30 to 40 miles. However, it is claimed that an unusually large amount of milk is consumed in the eity, much of it heing employed in cooking; bread male with milk is used to a large extent. It is estimated that the resilents of the city pay annually for milk $\$ 1,095,000$. Milk is distributed from 400 stores and 350 wagons. About 85 per cent of the supply is delivered in glisis hottles, and these are filled at the farms. Only alonut me two-hundredth part of the milk is pasteurized, and this treatment does not seem to be increasing in favor. The retail price of milk is 5.2 cents per quart, both smmmer and winter, its profucers receiving 3.3 .3 cent per quart throughout the year. Twenty-fice of the dairies which are conducter in the most satisfactory manner sell their produet at 7 cents per puart in smmer and 8 cents in winter. Within the eity limits there are 340 dairy herds, including 4,036 heal. Five hundred and sixty-eight dairy farms send milk into the (ity; about 1 per cent is received by railway, the longest shipment being 25 miles.

The eity authorities appropriate $\$ 1,000$ annually for the supervision of the milk supply. Three officers give a part of their time each day to this work. During the past year 1,400 samples of milk were examined, 200 general bacteriological examinations were made, and 316 dairy herds within the city limits were inspected. 
The form for recording data regarding milk samples is shown in Appendix IV (p. 204.)

The form for reporting analyses of milk samples is shown in Appentix IV (p. 206).

Previous to April, 1899, little was done to govern the supply of milk in this city. Since that date facilities for examining milk samples have been provided by the equipment of a new laboratory.

The recent introduction of a large number of cows giving rich milk has caused a marked improvement in the quality of the supply. An ordinance is needed to regulate the sanitary condition of places where milk is kept.

\section{Fall River. (Population, 104,863.)}

[For comparison with other cities in Class I, see p. 26.]

Thomas F. Wiseman, secretary of the board of health.

The daily consumption of milk is estimated at 6,000 gallons, or about 0.46 pint per capita. The entimated quantities of skimmerl milk and cream used daily are 4 and 50 gallons, respectively. Milk is distributed from 327 stores and 320 wagons. About 10 per cent of the milk is delivered in glass bottles, and the portion thus handled is increasing. The bottles are filled almost exclusively at the farms. Little, if any, milk is pasteurized. The retail price of milk is 5 to 6 cents per cuart in summer and 6 to 7 cents in winter. The producers on the farms realize $3 \frac{1}{2}$ to $4 \frac{1}{2}$ eents per quart in summer and 4 to $5 . \frac{1}{2}$ cents in winter. The product of five well-conducted dairies is sold for 7 cents per quart throughout the year. Within the rity limits there are 105 herds of milch cows, including 350 head. Two humbed and forty dairy farms send milk into the eity. All these are within a radius of 10 miles, and the milk is brought in by teams.

An ordinance adopted June, 1899, and milk regulation No. 71 refer to the milk supply. A license to sell milk in a store or from a wagon must be olstained from the board of health, and all dairy premises, vessels, and vehicles must be kept in a sanitary condition satisfactory to said hoard. License must be posted in stores and carried in delivery wagons, and wagons must bear owner's name and wagrom and license numbers. Milk adulterated by watering, skimming, or by the adlition of any foreign substance, milk from diseased cows or cows fed on distillery waste or other fermented food, milk from cows within fifteen days hefore or five day's atter calving, or milk from cows kept in a crowded or unhealthy condition is prohihited, and may be seized and destroyed. The milk standard is 12 per cent solids, 3 per cent fat. Perwons selling skimmed milk must ol,tain a special license from the buard of health, and delivery wagons and vessels must be plainly marked "skimmerl milk," ete. Milk shall not he kept, nor bottles washed, in any room used for sleeping or any domestic purposes or in a rom opening into the same, nor shall milk he stored in a stable, and a room separate from the stable and water-eloset shall he provided on dairy farms for straining and cooling milk, the same to have tight floors and walls. Cows must be examined at least once a year for tuberculosis and other contagions diseases in a manner approved by the board of health. All dairies shall be insperterl at least every June and December, and written report of their condition filed with the city clerk for public examination. Walls of cow stables must he cleaner and whitewashed at least once every six months. Milk in stores must he kept in a refrigerator or other tight receptacle separate from any food or contaninating prosuet, and ieed in warm weather. Milk in wagrons shall be proterted from dust, and on the streets it shall never be transferred from one vessel to another except when delivered to the consumer. Milk shall not be sold in bottles unless they are firnt washed with hot water cleaning solution and then with rlean hot water; they must not be filled except at the dairy or ereamery, or in a room free from dust. Vessels hambled by persons suffering from a contagrions discase must be sterilized before 
being used to hold milk. No attendant suffering from or suspected of a contagious disease is allowed to care for cows or handle milk. Every person engaged in handling milk must notify the boart of health and stop the sale of milk when an infectious disease is discovered $\mathrm{in}$ his family or among his employees.

The section referring to skimmed milk is shown in Appendix I (p. 179).

About $\$ 1,250$ is expended annually in the supervision of the milk supply. One milk inspector gives his entire time to this work. During the year 257 samples were examinerl by the Babcock test, 7 being found below standard; no hacteriologieal examinations were made. All the dairies within the eity and all of the dairies and farms sending milk to the city were inspected.

Nince the appointment of a milk inspector there has been much improvement in the sanitary condition of dairies, milk utensils, etc. It is believed that to a certain extent the production of market milk should be under State anthority. Frequent bacteriological examinations of the inilk supply should be made.

The form for recording inspection of stores, ete, is shown in Appendix IV (p. 207). The form for recording inspection of wagons, etc, is shown in Appendix IV (p. 208).

Lowell. (Population, 94,969.)

[For comparison with other cities in Class II, see p. 30.]

Thomas $O$. Allen, inspector of milk and vinegar.

The daily consumption of milk is estimated as 7,700 sallons, or 0.65 pint per (atpita, besides 200 gallons of skimmed milk and 50 gallons of cream. Milk is sold from almut 350 stores and 156 wagons. (ilass bottles are used in the delivery of about one-fourth of the total supply, and are filled both in the city and at the dairy farms. Only about 3 per cent of the mik is pasteurized, and there is no increase in the practice. The retail price of milk is 5 cents per quart in summer and 6 cents in winter, the producers receiving 2.7 cents in summer and 3 cents in winter. The product of one "model dairy" near the city is sold for 7 cents per quart thronghout the year. There are only about 100 cows within the city limits, and no data are available as to the umber of dairy farms sending milk into the city. About 300 gallons is shipped into the city by railway, the longest shipment being 20 miles.

State laws regulate the milk supply.

The supervision of the milk and vinegar cost the city last year \$2.329.97. Two oflicials-one inspector, who is also city analyst, and one collector of samples-give their entire time to this work. During the past year 2,972 samples of milk were examinel by the Balreck test and by gravimetric analysis; only a few hacteriological examinations were made.

The averages of total solids in samples of milk collecterl from wagons aud stores, in different months of the year, are as follows:

\begin{tabular}{|c|c|c|c|c|c|}
\hline & $\begin{array}{c}\text { From } \\
\text { wagons. }\end{array}$ & $\begin{array}{l}\text { From } \\
\text { stores. }\end{array}$ & & $\begin{array}{c}\text { From } \\
\text { wagons. }\end{array}$ & $\begin{array}{l}\text { From } \\
\text { stores. }\end{array}$ \\
\hline January ............ & $\begin{array}{r}\text { Per cent. } \\
12.80\end{array}$ & $\begin{array}{r}\text { Per cent. } \\
12.16\end{array}$ & July .......... & $\begin{array}{r}\text { Per cent. } \\
12.70\end{array}$ & $\begin{array}{r}\text { Per cent. } \\
11.50\end{array}$ \\
\hline February ........ & 12.92 & 12.41 & August..... . & เ2. 72 & 12.06 \\
\hline Mareh.......... & 13.16 & 12.98 & September . ............. & 13.00 & 12.83 \\
\hline April ...... & 13.11 & 13.21 & October........... & 13.07 & 12.47 \\
\hline May ....... & 12,82 & 13. 20 & November ........................ & 13.03 & 11.94 \\
\hline June........................ & 12.92 & 12.05 & 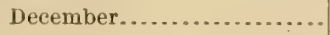 & 13.00 & 12.77 \\
\hline
\end{tabular}

It is stated that a law is needed to regulate the sanitary condition of dairy barns, lots, pastures, etc., and that it would be well to have a standard of cleanliness for dairies, those not coming up to it to he excluled from the privilege of selling milk in the city. 


\section{Cambridge. (Population, 91,886.)}

[For comparison with other cities in Class II, see p. 30.]

Philip P. Sharples, inspector of milk.

The daily consumption of milk is estimated as 9,074 gallons, or 0.79 pint per capita. In aldition to what is used by ice-cream manufacturers and bakers, 202 gallons of skimmed milk and 116 gallons of cream are nsed in family trade. There are sold, claily, 4,324 gallons of milk from 410 stores, 4,639 gallons by 156 milkmen, and 111 gallons from "private cows." Three-fourths of the milk used in family trate is delivered in glass hottles, the greater part of them being filled in the eity. Little or no milk is pasteurized; one concern tried it, but is now out of business. The retail price of milk is 4 to s cents per quart in summer and 5 to 9 cents in winter, the producers receiving $3 \frac{1}{4}$ cents in summer and $3 \frac{1}{2}$ cents in winter. The milk of a few well-comlucted dairies near the city is sold for 8 cents per quart in summer aud 9 cents in winter. Within the city limits there are 76 herds of milch cows, including 234 head. Five hundred or more dairy farms send milk into the city. The city herds produce, daily, 476 gallons of milk; wagons haul to the eity 3,770 gallons, and rail way trains bring 4,828 gallons. The longest shipment is 100 miles.

The city has no milk ordinance, the milk supply being regulated by State laws.

Gne thousand five humdred dollars is expended annually in the supervision of the milk supply. Two officials-an inspector and his deputy-give one-half of their time to this work. During the past year 3,36 t samples of milk were examined by the Babcock test; ruspected samples were tested for coloring and preservatives, and all the city herds were inspected.

The form used when applying for milk license is shown in Appendix IV (p. 18s).

Recent improvement in the cutality of the milk supply is said to be due to the fact that it is now largely in the control of eoncerns that pay strict attention to the character of the milk they handle. It is recommended that the license fee for stores be raised to $\$ 50$.

\section{Lynn. (Population, 68,513.)}

[For comparison with other eities in Class II, see p. 30.

William E. Welts, inspector of milk.

The daily consumption of milk is estimated as 6,000 gallons, or 0.70 pint per capita, besicles 600 gallons of skimmed milk and 125 gallons of cream. Milk is sold from 350 stores and 75 wagons. Cilass bottles are used to a limited extent in the delivery of milk, these being filled hoth in the eity and at the producing farms. Only a very small quantity of milk is pasteurized and the practice is decreasing. The retail price of milk is $t$ to $t$ cents per quart, hoth summer and winter, the producers receiving 2 to $3 \frac{1}{2}$ cents per quart throughout the year. A few especially well-conducted dairies near the city sell their product for 7 cents per quart the year round. Within the city limits there are 60 herds, including 350 cows, and milk is sent into the city from alwot 800 dairy farms. Two-thirds of the entire milk supply is shipped by railway, the longest shipment being about 300 miles.

Regulations adopted in April, 1899, supplement the State laws referring to the milk supply. Cows which produce milk for the city must have been examined (within one year) and found free from dangerous disease. Rooms where milk is handled must he properly constructed and located; all dairy utensils must be kept clean and, when exposed where contagious disease exists, must be thoroughly sterilized. Milk from places where there is any contagious disease is prohibited.

The eity expends $\$ 2,500$ annually in the supervision of its milk supply. Two officials-an inspector and a collector of samples-give their entire time to this work. The number of milk samples examined during the past year is not rejorted; all the 
herds in the city and all the dairy farms within the State sending milk to the city have been inspected.

Recently the quality of the milk supply has improved, due to the enforcement of the milk regulations. It is recommended that tuberculin tests be made of cows ontside the State producing milk for the city.

\section{Lawrence. (Population, 62,559.)}

[For comparison with other cities in Class II, see p. 30.]

Michael A. Scanlon, inspector of milk.

The daily consumption of milk is estimated as 6,000 gallons, or 0.76 pint per capita, besides 500 gallons of skimmed milk and 200 gallons of eream. Milk is sold from 700 stores and 200 wagons. Glass bottles are used quite extensively in the delivery of milk. The increase in their use will be checked by the destruction of some bottles under an act of the State legislature requiring all bottles to be sealed by the sealer of weights and measures. The bottles are filled mostly at the producing farms. Little or no milk is pasteurized. The retail price of milk is about 6 cents per quart throughout the year. The producers realize $2 \frac{1}{2}$ to :3 cents per quart in summer and $3 \frac{1}{2}$ to 4 cents in winter. Within the city limits there are 8 dairy herds, including 130 cows. The longest shipment of milk from the country is 12 miles.

State laws regulate the city milk supply.

Only about $\$ 550$ is expentert annually in the supervision of the city milk supply. The inspector (salary $\$ 150$ per year) grives one hour daily to this work, oceasionally going ont to collect samples. During the past year 179 samples were examined by the Babcock test, and all of the city herds were inspected. When milk samples are found by the Babcrek test to be below the standard, they are submitted to chemical analysis, for which the city pays $\$ 2$ per sample.

Recently a more e'ven quality of milk has been supplied, owing to mixing the milk of numerous herls of cows, and its quality has improved hecause of more sanitary conditions at dairies. It is stated that the license fee should be raised from 50 cents to $\$ 25$ or more, and closer attention should be given to producing dairies.

New Bedford. (Population, 62,442.)

[For eomparison with other cities in Class II, see p. 30.]

Daniel C. Ashley, D. V. S., inspector of milk, provisions, and animals.

The daily eonsmmption of milk is extimated as 7,000 gallons, or 0.90 pint per eapita. Milk is sold from 201 stores and 170 wagons. A very small part of the milk is delisered in glass bottles, and these are filled at the producing farms. No milk is pasteurized. The retail price of milk is about 6 cents per quart throughout the year, producers receiving 3 to $3 \frac{1}{2}$ cents in summer and $3 \frac{1}{2}$ to 4 cents in winter. There are no "model dairies" near the city. Within the city limits there are 700 milch cows, kept 1 to 20 in a place. Milk is received from many of the adjacent towns. Only a small portion of the supply comes in ly railway, the longest shipment being 20 miles.

State laws regulate the milk supply.

Ahout $\$ 1,500$ is expended ann!ally for the inspection of nilk, provisions, and animals. Two officials-an inspector and one assistant-give their entire time to this work. During the past year 900 samples of milk were examined by lactometer, lactoscope, etc.; no bacteriological examinations were made; all the city herds were inspected.

The inspector states that the most neederl improvements are a more thorough inspection of milch cows with the aid of turberculin, and the enforcement of a requirement that dairy utensils be scalded after use. 


\section{Springfield. (Population, 62,059.)}

[For comparison with other cities in Class II, see P. 30.]

James Kimball, inspector.

The daily consumption of milk is estimated as 4,750 gallons, or 0.61 pint per (anjita. Milk is sold from 103, stores and 13:3 wayons. Ahout 1,000 quarts of milk is ilelivered in glass bottles, which are filled in the city. No milk is pasteurized. The retail mice" of nilk is 6 cents per quart, both summer and winter, except bottlesl nilk, which sells for 7 cents per quart. The producers receive :" "ents per quart in summer and $3 \frac{1}{2}$ cents in winter. There are no "model dairies" in or near the eity. Within the city limits there are 20 herds of milch cows, including 130 hear, besides alout 100 cows kept in private stalls, 1 or 2 in a place. Milk is sent into the city from 420 dairy farms. All the milk is brought in by teams, the longest haul being 14 miles.

A cooperative milk association controls a large part of the trade in Springfield. This association was organized in 1884. According to the fifteenth annual report (1899), the receipts of milk cluring that year were $2,911,218$ ynarts, which was 38,000 quarts less than the receipts of the previous year. There was paid to the farmers $\$ 68,751.29$, which was $\$ 1,373.08$ more than in the previous year. The report showed 150 patrons, 86 of whom were stockholders.

There is no city milk ordinance.

The city expends annually $\$ 100$ in the supervision of its milk supply. During the past year a number of samples were examined hy the lactometer and the babeod test.

Recent improvement has been made in the milk supply, by an organized effort on the part of dealers recpuiring the proshecers to arlopt better sanitary methorls in handling milk. There is need for a thorough inspection of all premises where milk is handled.

\section{Somerville. (Population, 61,643.)}

[For comparion with other cities in Class II, see p. 30.]

\section{J. E. Richardson, inspector of milk and vinegar.}

The quantity of milk sold daily is reported as 7,640 gallons, or an average of 0.99 pint per capita, besides 400 gallons of skimmed milk and 500 gallons of eream. In explanation of the apparently laree comsmmption of milk it is staterl that a part of the milk reported is probably sold in adjacent towns. Milk is sold from 300 stores and 185 wagons. In addition to the above, there were 5 cream teams, 1 condensed milk, and 1 modified-milk team licensed. Glass hottles, filled in the city, are used in the delivery of about one-half of the milk supply. Only a limited amount of milk is pasteurized, with no increase in the practice. The retail price of milk is 6 cents per quart in summer and 7 cents in winter, the producers receiving 3 cents in summer and 4 cents in winter. There are no "model dairies" near the city. Within the the city limits there are 2 herds, including 62 milch cows, besides 222 cows kept 1 or

a'The retail prices established by the local milk dealers' association are as follows:

$$
\begin{gathered}
\text { cents } \\
\text { per cluturt. }
\end{gathered}
$$

Pasteurized and sterilized milk. . . . . . . . . . . . . . . . . . . . . 8

Bottled milk .......................................... 7

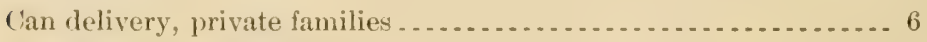

Boarding houses, hotels, ete:

Less than 5 quarts daily .............................. 6

From 5 to 10 quarts daily ............................. 5

Ten quarts or more daily . . . . . . . . . . . . . . . . . . . . . . . . 41

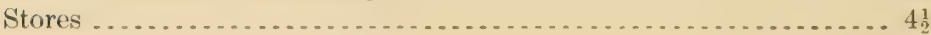


2 in a place. There is no record of the number of dairy farms sendine milk into the city. Seven-eighths of the total supply is received by railway, the longest shipment being 175 miles.

The milk supply is regulated by State laws.

Ahout 500 is expenterl amnually in the supervision of milk, one inspector giving a part of his time to this work. During the past year 5is samples of milk were examinerl hy the Babcock test and hy gravimetric analysis; no bateriological examinations were made; 19 milk cases were prosecuted.

\section{Holyoke. (Population, 45,712.)}

[For comparison with other cities in Class III, see p. 36.]

James K. Morrill, inspector of milk and vinegar.

The laily consumption of milk is estimated as 4,373 gatlons, or 0.77 pint per capita; alko) ths gallons of skimmerl milk and 6:3 gallons of ('ream. Milk is sold from 17: stores and 136 wagons, and about 25) per cent is delivered in glaks bottles, which are filled mostly at the farms. Very little milk is pasteurized, and the practice is not increasing. Milk is retailed at 5 cents per quart in summer and 6 cents in winter, the producer receiving $3 \frac{1}{4}$ cents and $3 \frac{3}{4}$ cents, respectively. The milk from a few specially well-conducterd dairies near the city is sold for 7 cents per quart in summer and 8 cents in winter. Within the city limits there are 78 herds, including s.5 cows,

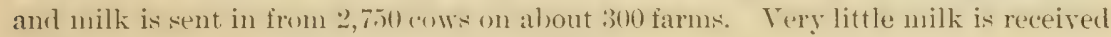
by railway, the longest shipment being 16 miles.

The city has no milk ordinance, but prints State laws referring to milk.

The city expends annually about $\$ 500$ in the supervision of its milk supply, two oflicials giving nearly half their time th this work. During the past year 260 - wimples of milk were examined by the Babcock test; no bacteriological examinations were marle; all the city herds were inspected, and there were 5 prosecutions for violations, and 14 warnings. The prosecutions were: One for selling skimmed milk from a can not properly marked, 1 for prestling milk without license, :3 for selling milk from stores without license.

The form for warning anainst the sale of adulterated milk is shown in Aplendix IV (p. 209).

It is stated that there should he some limitation to sale of milk in matkets, camly stores, etc., snd that glass bottles should be more generally used.

\section{Brockton. (Population, 40,063.)}

[For comparison with other cities in Class III, see p. 36.]

Benjamin Thatcher, inspector of milk.

The daily consmuption of milk is estimaterl as 3,200 gallons, or 0 . 6 th pint per capita, besicles 50 grallons of skimmerl milk and 40 gallons of cream. Milk is sold from 150 stores and 150 watrons. Alout one-half the milk is supplied in ghats bottles filled at the farms, and a large percentage of it is pasteurized. The retail price of milk is 6 cents per quart throughout the year. There is one "model dairy" near the city, but its product is not sold for an extra price. Within the city limits there are 41 herds, including 58t cows. Milk is supplied from 20 dairy famm, the most distant one being 16 miles. No milk is received by railway.

The city has no milk ordinance or regulation.

During the past year $\$ 100$ was expenteel for milk-inspection work; 25 samples of milk were examined; all the city herds and all the dairy farms were inspected. 
Haverhill. (Population, 37, 175.)

[For comparison with other cities in Class III, see p. 36.]

Grantley W. Bickell, inspector of milk.

The daily consmmption of milk is estimated as 3,290 gallons, or 0.71 pint per capita. Milk is sold from 120 stores and 100 wagons. Glass hottles, filled at the farms, are ued very largely in the delivery of milk. No milk is pasteurized. The retail price is 6 cents per quart throughout the year, the producers receiving 3 cents and $3 \frac{7}{2}$ cents, respectively, in summer and winter. The milk from a few dairies conducted in a very satisfactory manner is sold at the regular price. Within the eity limits there are 120 herds, including about 1,000 cows, and milk is sent in from 125 dairy farms, the most distant being 10 miles.

A city ordinance requires four dairy inspections per year.

The city expends annually about $\$ 150$ in the supervision of its milk supply. No one official gives his entire time to the work. During the past year 275 samples of milk were examined by lactometer and Babock test; no bacteriological examinations were matle; all the city herds and 39 of the 125 dairy farms were inspected.

The form to accompany application for milk license is shown in Appendix IV (p. 191).

Improvement has recently been shown in the grade of cows, sanitary conditions of the buildings, and the care of utensils. The importance of having attendants free from disease is emphasized.

Salem. (Population, 35,956.)

[For comparison with other cities in Class III, see page 36. ]

R. L. Newcomb, clerk of the board of health.

The daily consumption of milk is estimaterl as 4,200 gallons, or $0.9 \% 3$ pint per capita,

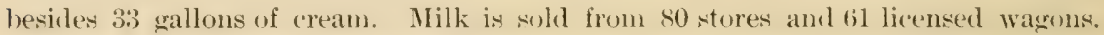
One-third of the total quantity delivered is supplied in glass bottles, filled either at the farms or in the city. About 20 gallons of milk is pasteurized daily, and is sold for 7 cents per quart. The demand for milk so treated is increasing. The retail price of milk is 6 to 7 cents per quart in summer and 6 to 8 cents in winter, producers receiving $: 3 \frac{1}{2}$ to 4 cents throughout the year. The milk from a few especially well-conducted dairies near the city is sold for 7 to 8 cents per quart. Within the city limits there are 6 herels, including about 185 cows, and milk is sent in from 20 dairy farms, the most distant being 12 miles.

State officials supervise the milk supply.

Chelsea. (Population, 34,072.)

[For comparison with other eities in Class III, see p. 36.]

George F. Marsh, inspector of milk.

The daily consmuption of milk is estimated as 3,800 gallons, or 0.89 pint per capita, besides 100 gallons of skimmed milk and 40 gallons of cream. Vilk is sold from 179 stores and 46 wagons. Glass bottles are used almost entirely for retail delivery, being filled in the city. Nilk is pasteurized only for special orders, and the practice is not increasing. The retail price of milk is 4 to 7 cents per quart in summer, and 5 to 8 cents in winter. There are no "model dairies" near the city. Within the city limits there are 15 herde, including 140 cows. Ninety per cent of the milk is furnished by Boston contractors.

About 5225 is expended hy the eity for milk-inspection work. During the past year 1,058 samples of milk were examined by the lactoscope; no bacteriological examinations were made; all the city herds were inspected.

An inspector is needed who is well equipped for the work and able to give it sufficient time. 
Malden. (Population, 33.664.)

[For comparison with other cities in Class III, see p. 36.]

Henry M. Hartshorn, inspector of milk and vinegar.

The daily consumption of milk is estimated as 3,000 gallons, or 0.71 pint per capita, besides skimmed milk and cream in variable quantities. Milk is sold from 95 stores and 45 wagons. Only a few milkmen use glass bottles in the delivery of milk, and these are filled in the city. Little or no milk is pasteurized. The retail price of milk is 6 cents per quart in summer and 7 cents in winter, producers receiving $3 ! 2$ and 4 cents, respectively. There are no "model dairies" near the city. Within the city limits there are 25 herds, including 183 aws. About half of the milk supply is received by railway, the longest shipment heing 75 miles; this latter portion is believed to be of poorer quality than the milk produced near by.

The revised ordinances of 1894 , chapter XXX, supplement the state laws in regard to milk. License fee for the sale of milk is 50 cents. Name and place of business of every person convicted of selling adulterated milk must be printed in two newspapers in the city or county, as well as in the report of the milk inspector.

The ordinance section regarding publication of names of violators is given in Appendix I (p. 180).

The city expends annually about 8300 in the supervision of its milk supply, one ofticial given a part of his time to this work. Inring the past year 455 samples of milk were analyzed gravimetrically; no bacteriological examinations were made; nearly all the city herds were inspected.

The examination of samples for milkmen and consumers is believed to have a beneficial and improving effect.

Newton. (Population, 33,587.)

[For comparison with other cities in Class III, sec p. 36.]

Arthur Hudson, inspector of milk.

The daily consumption of milk is estimater as 5,275 gallons, or 1.25 pints per capita, besiles 32 gallons of cream. Milk is sold from 140 stores and 130 wagons. Threefourths of the milk is delivered in glass bottles, filled both in the city and at the farms. Very little milk is pasteurized, but the practice is increasing. The retail price of milk is 7 to 8 cents per quart throughout the year, producers receiving 3.1 to 4 cents. The milk from one "model dairy" near the city is sold remularly for 8 cents per quart. Within the city limits there are 41 herds, of 7 or more animals each, including 1,170 cows, hesides those kept by private families. Sixty-three dairy farms send milk into the city. Only 21 gallons of milk is receiverl daily by railway, the longest shipment being 50 miles.

During the past year $\$ 601.39$ was expended in the supervision of the dity milk supply, one inspector giving about half of his time to this work. Samples to the number of 1,562 were examined hy lactometer, doubttul sumples by gravimetric analỵsis; bacteriological examinations were marle for tuberele, typhoid, and lactis viscosis bacilli; all the city herds were inspected.

The form for notification that license to sell milk must be secured is shown in Appendix IV (p. 200).

There has been a recent improvement in the sanitary conlitions at dairies and in the methofis of handling milk. It is urged that printed instructions regarding the feeding of animals and the cooling and bottling of milk be distributed among milk producers. 


\section{Fitchburg. (Population, 31,531.)}

[For comparison with other cities in Class III, see p. 36.

John F. Bresnahan, inspector of milk.

The daily consumption of milk is estimated as 4,541 gallons, or 1.15 pints per eapita, besicles 45 gallons of cream. Milk is sold from 99 stores and 126 wagons. Glass bottles, fillerl at the farms, are used quite extensively in the delivery of milk. No milk is pasteurized. The retail price is 6 cents per quart throughout the year, producers receiving $2 \frac{3}{5}$ cents in summer and $2 \frac{4}{5}$ cents in winter. The milk from a few wellcomblueterl dairies near the eity is sold at the regular price. Within the eity limits there are :3t herds, incluling 404 cows, and milk is sent in from 1,152 cows on 58 dairy farms within 12 miles of the city.

Board of health regulations, May and June, 1897, supplement the State laws in regard to milk. A special license is required for the sale of skimmed milk. Milk hottles must he filled in properly constructed rooms and he thoronghly cleaned hefore using. Milk should be kept at a temperature below $50^{\circ} \mathrm{F}$. In selling milk, the contents of a can should be mixed before measuring out the desired quantity. Cow stables must be properly constructed and located, and be kept clean. Cows must he gromed at least three times a week when kept in stahles. Adulterated, etc., milk is prohibited, and may he seized and destroyed. The milk standard is 12 per cent solids, 3 per cent fat.

The dity expends ammually $\$ 300$ (?) in the supervision of its milk supply as the salary of the milk insuector. During the past year 25 samples of milk were examined by the lactometer; 4 hacteriological examinations were made for bacilli of typhois! fever and diphtheria. All of the city herds but none of the dairy furms were inspected.

\section{Taunton. (Population, 31,036.)}

[For comparison with other cities in Class III, see p. 36.]

F. M. Seudder, inspector of milk.

The daily comsumption of milk is estimated as 2,532 gallons, or 0.65 pint per capita. Milk is sold from 26 stores and 135 wagons. It is retailed at 6 cents per quart throughout the year. There are no "model dairies" near the city. Within the city limits there are 77 herds, including 810 cows. The most distant dairy farm suplying milk is 9 miles from the city. No milk is received by railway.

thout 850 is expender annually by the city in the supervision of its milk supply, one inspector grving a part of his time to this work. During the past year 7 samples of milk were examined hy the lactometer; no bacteriological examinations were made; all the city herds and nearly all of the dairy farms were inspected.

Gloucester. (Population, 26,121.)

[For comparison with other cities in Class III, see p. 36.]

Fred Corliss, inspector of animals, provisions, milk, and vinegar.

The daily consumption of milk is estimated as 2,300 gallons, or 0.70 pint per capita, besides 125 gallons of eream. No skimmed milk is sold. Milk is sold from 124 stores and 88 wagons. Glass bottles, filled at the farms, are used in the delivery of about 12 per cent of the milk supply. Very little milk is pasteurized and the praktice is not increasing. Milk is retailed from stores at 6 cents per quart and from wagons at 7 cents throughout the year, the producer receiving :3! cents. Within the city limits there are about 700 cows and 50 herds. The most distant dairy farm supplying milk is 16 miles from the city.

The city expends ammually $\$ 150$ in the supervision of its milk supply, the inspertor giving a part of his time to this work. During the past year all of the city (n)w were inspected; no samples of milk were examined for composition. 
North Adams. (Population, 24,200.)

[For comparison with other cities in Class IV, see p. 40.]

Albert G. Nichols, inspector of milk.

The daily consumption of milk is estimated as 2,000 gallons, or 0.66 pint per capita, besides 75 gallons of skimmed milk and 25 gallons on cream. Milk is sold from 10 stores and 50 wagons. About one-fourth of it is delivered in glass bottles filled at the farms; little or none is pasteurized. The retail price is 5 cents per quart in summer and 6 cents in winter, producers receiving 3 cents throughout the year. There are a few dairies conducted better than others, but they do not receive an advance in price for their product. Within the city limits there are 27 herds, including 377 cows, and milk is brought in wagons from 75 dairy farms, the longest haul being 9 miles.

An ordinance adopted in February, 1900, refers to milk. It requires that dairies, etc., be inspected in June and December, and premises and apparatus he kept clean; that cows be free from tuberculosis, and stables be whitewashed; that milk rooms be properly located and constructed; and that persons handling milk be free from contagious disease.

One hundred dollars is expended annually in the supervision of the milk supply, but this does not include a portion of the salary of the inspector of animals. During the past year about 300 samples of milk were examined by the Babcock test; no bacteriological examinations were made; all the city herds and all the dairy farms were inspected.

Recent improvement in the city milk supply is due to an increased use of bottles. Further improvement would result from the pasteurization of milk and the sterilization of utensils.

\section{Woburn. (Population, 14,254.)}

[For comparison with other cities in Class IV, see page 40.]

Gorden Parker, inspector of milk and vinegar.

The daily consumption of milk is estimated as 1,032 gallons, or an average of 0.58 pint per capita. Milk is sold from 16 stores and 30 wagons. Glass bottles are in general use in the delivery of nilk and are filled in the city and at the farms. Little or 110 milk is pasteurized. The retail price is 6 cents per quart throughout the year, producers receiving $3 \frac{1}{8}$ cents and $3_{4}^{3}$ cents in summer and winter, respectively. There are no "model dairies" near the city. The longest distance milk is supplied to the city is 5 miles.

One hundred dollars is expended annually in the supervision of the milk supply. During the past year 25 samples of milk were examined by lactometer and gravimetric analysis. Cattle are inspected by the local inspector of cattle and provisions under the direction of the State board of health.

Improvement of the milk supply might be brought about by frequent inspection of herds and barns, and by educating consumers as to what good milk is, so that they will demand it.

Melrose. (Population, 12,962.)

[For comparison with other eities in Class IV, see p. 40.]

William S. Briry, inspector of milk and vinegar.

The daily consumption of milk is estimated as 800 gallons, or 0.49 pint per capita, besides 25 gallons of skimmed milk and 20 gallons of cream, IIilk is sold from 49 stores and 69 wagons. Nearly all milkmen deliver milk in glass bottles filled in the city. Some cream is pasteurized, and the practice is increasing. The retuil price of milk is 5 to 7 cents per quart thronghont the year, producers receiving 4 cents. Six $25839-$ No. $46-03-7$ 
dairies, better conducted than others, receive 7 cents per quart for their product. Within the city limits there are 40 herds, including $150 \mathrm{cow}$, and milk is sent in from 25 dairy farms. About 5 per cent is received hy railway, the longest shipment heing 10 miles.

The city prints State laws relating to the inspection and sale of milk.

One humbred dollar is expended annually in the supervision of the milk supply, one ofticial giving a part of his time to this work. During the past year 36 samples of milk were examined hy lactometer and gravimetric analysis; no bacteriological examinations were made.

Wakefield. (Population, 9,290.)

[For comparison with other cities in Class IV, see p. 40.]

Josiah S. Bonney, inspector of milk.

The daily eonsumption of milk is estimated as son gallons, or an average of 0.68 pint per capita. Milk is sold from 93 stores and 54 wagons. A large amount of milk is delivered in glass bottles filled at the farms; little if any is pasteurized. The retail price is 6 cents per quart throughout the year, producers receiving $3 !$ cents in summer and 4 cents in winter. A few well-conducted dairies receive 7 cents per quart for their product. Within the vity limits there are $8: 3$ herds, including 343 cows. About 12 per cent of the milk is received loy railway, the longest shipment being 35 miles.

There is allowerl anmually the sum of $\$ 150$ as salaries of milk inspector and collector. During the past year 154 samples of milk were examined by the Babeock test and gravimetric analysis; no hacteriological examinations were made; all the eity herds were inspected; $\$ 150$ was collected as fines, and $\$ 40$ as license fees.

The inspector believes that hetter sanitary conditions should obtain at dairies, and that all the milk should be pasteurized.

\section{North Attleboro. (Population, 7,253.)}

[For comparison with other cities in Class IV, see p. 40.].

\section{Henry Kling, inspector of milk, provisions, and cattle.}

The daily consumption of milk is estimated as 88.5 gallons, or 0.98 pint per capita. Milk is sold from 6 stores and 34 wagons. Four dealers deliver milk in glass lottles filled at the farms. No milk is pasteurized. The retail price is 6 cents per quart throughout the year, producers receiving 3 to $3 \frac{1}{2}$ cents in summer and 4 cents in winter, There are no "model dairies" near the city. Within the city limits there are 24 herds, including 275 cows, and milk is brought in wagons from 8 dairy farms, the longest haul being 4 miles.

About $\$ 200$ is expended annually in the supervision of the milk supply, one oflicial giving a part of his time to this work. During the past year 150 samples of milk were examined by the Babcock test; no bacteriological examinations were made; 535 cows were inspected, and 3 condemned for tuberculosis.

A copy of the form used for placing a cow or cows in quarantine when suspected of having tuberculosis is shown in Appendix IV (p. 199).

Recent improvement in the milk supply is due to cleaner barns and cows and to more care in handling milk. It is recommended that employees wear special clothes while milking; that milk be removed from the stable immediately after milking; that cows be fed pure feeds and curried daily, and that udders be washed before milking.

\section{MICHIGAN.}

IV. B. Snow, dairy and food commissioner, Lansing.

I'ublic acts of 1893 -No. 211, amended, provides that the dairy and food commissioner shall inquire into the quality of dairy products sold in the State, and gives him 
authority to take samples for analysis. Prosecuting attorneys shall assist in enforeing the food laws. Monthly bulletins shall be issued showing results of inspections.

Public acts of 1887, No. 246, amemiterl; 1899, No. 106, and 1873, No. 26, refer to milk and milk inspertors. The police commissioners of Itetroit appoint a milk inspector, with rank of eaptain, sergeant, or roundsman. He is given anthority and resuired to make inspertions in Ietroit and Wayne ('ounty. ('ommon councils of rities and hoards of trustees or comods of villages may appoint milk insperetors with similar powers. It is unlawful to sell unwholesome, arlulterated, or impure nilk; or swill milk; or colostrum; or milk from cows kept on garbage, swill, or any fermenting or deleterious substance; or milk from cows kept in connection with a family where there is an infectious disease; or milk, skimmerl milk, buttermilk, or rream to which water, preservatives, or any foreign substance has been added; or knowingly to sell milk from diseased cows or cows fed on the refuse of a distillery or a brewery. The milk standard is 12.5 per cent milk solids, s per cent fat, and a specifie gravity at $60^{\circ} \mathrm{F}$. hetween 1.029 and 1.033 . Skimmed milk must he plainly marked and have a specific gravity between 1.032 and 1.037 .

Public: arts of $1895-\mathrm{No}, 193$ forbids the sale of adulterated food, which term is defined at length.

The dairy and fool commissioner issues a monthly report showing in considerable detail the amount and character of the work performed. Fath report "ontains brief statements regarding the conditions of dairies vivited during the month in the vicinity of cities and towns throughout the state. The character of the statements concerning dairies can best be shown by cuoting one, which refers to an apparently well-managed place, and another referring to one in much need of improvenent; they are as follows:

(a) Condition of cows, very good and clean; feed, corn fodder, hay, and ground corn and oats; stables, very neat and clean and whitewashed; yard, clean and iry; ventilation, gond; water, well; milk roon, neat and clean, has cement floor; uses an aerator.

(b) Condition of cows, good; feed, forlder, corn, and chops; stablen, dirty and rlark; yard, muddy and filthy; ventilation, none; water, well.

This system of inspection is said to have had a very beneficial effect npon the milk supply of cities and villages. During the past year $4 t 7$ dairies supplying milk to $t 8$ cities and villages were reported upon, in the different months, as follows;

\begin{tabular}{|c|c|c|c|c|c|}
\hline $\begin{array}{c}\text { Month of inspere- } \\
\text { tiun. }\end{array}$ & Citien nurl villages. & $\begin{array}{l}\text { No. of } \\
\text { inspece- } \\
\text { tions. }\end{array}$ & $\begin{array}{c}\text { Month of inspee- } \\
\text { tion, }\end{array}$ & Cities and villages. & $\begin{array}{l}\text { No. uf } \\
\text { insirece } \\
\text { tions. }\end{array}$ \\
\hline January .......... & Lansing ......... & 40 & September:.... & Flint ........... & 16 \\
\hline \multirow{2}{*}{ February ........ } & Typsilanti.... & 8 & & Holly . ........... & \\
\hline & Battle Creek .. & 45 & & Mount Pleasant. & \\
\hline March.. & Jackson ....... & 57 & October ... & St, Clair .......... & \\
\hline \multirow{5}{*}{ April ............ } & Adrian ..... & 16 & & Marine City ..... & \\
\hline & Hudson .... & 3 & & Algonac.......... & \\
\hline & Waldron .... & 1 & & Mount Clemens .. & \\
\hline & Hillsdale.... & 6 & November...... & Reading......... & \\
\hline & Jonesville..... & 6 & & Hillsdale....... & \\
\hline \multirow{8}{*}{ May ............. } & Eaton Rapids.... & 4 & & Adrian .......... & \\
\hline & Charlotte...... & 5 & November...... & Union City ...... & \\
\hline & Wryne....... & 5 & & Three Rivers.... & \\
\hline & Northville.... & 2 & & Cassapoiis ....... & \\
\hline & Albion ....... & 6 & & Kalamazoo..... & \\
\hline & Marshall ..... & 6 & & Nliegan ......... & \\
\hline & Grass Lake ... & 1 & & Benton Harbor.. & \\
\hline & Chelsea........ & 5 & & St. Joseph ....... & \\
\hline June. & Saginaw.......... & 68 ! & & Monroe......... & \\
\hline
\end{tabular}




\begin{tabular}{|c|c|c|c|c|c|}
\hline $\begin{array}{l}\text { Month of inspece- } \\
\text { tion. }\end{array}$ & Cities and rillages. & $\begin{array}{l}\text { No. of } \\
\text { inspece- } \\
\text { tions. }\end{array}$ & $\begin{array}{l}\text { Munth of insine } \\
\text { tion. }\end{array}$ & (ities and villatges. & $\begin{array}{l}\text { No. of } \\
\text { inspec- } \\
\text { tions. }\end{array}$ \\
\hline \multirow[t]{2}{*}{ November.. } & SummerfieldTownship & 2 & December... & Homer ........... & 1 \\
\hline & Niles ............... & 4 & & Albion ....... & 3 \\
\hline \multirow[t]{9}{*}{ December ....... } & Port Huron....... & 25 & & Jonesville ...... . & 3 \\
\hline & Pontiac............. & 10 & & Manistee ............ & 1 \\
\hline & Lapeer ............ & 2 & & Big Rapids...... & 4 \\
\hline & Wyandotte... & 12 & & Eaton Rapids.... & 2 \\
\hline & Alma .................. & 4 & & Total inspections & \\
\hline & Ithaea .............. & 2 & & in 48 cities and & \\
\hline & Hart ............. . & 1 & & villages.......... & 417 \\
\hline & Frankfort ....... & 1 & & & \\
\hline & Cadillac ........ & 6 & & & \\
\hline
\end{tabular}

The department has waged a vigorsus campaign against the we of preservatives, and reports 49 prosecutions.

\section{Detroit. (Population, 285,704.)}

[For comparison with other cities in Class I, see 1). 26.]

M. B. Fauykner, milk inspector.

C. L. Stewart, M. D., milk inspector.

The daily consumption of milk is estimaterl as 15,000 gallons, or 0.42 pint per capita. While the daily receipts of milk are 25,000 gallons, a considerable portion of this is delivered to suburban places and used in the manufacture of ice crean, butter, and cheese. It is also estimated that 2,000 gallons of skimmed milk and 700 gallons of cream are consumed daily. Milk is sold from to0 stores and 230 wagons. Glass bottles are used in the delivery of ahout half the total supply. Pasteurized milk is used only to a small extent, but its use is increasing. The retail price of milk is 5 cents per quart in summer and 6 cents in winter, the producers receiving 2 cents in summer and $2 \frac{1}{2}$ cents in winter. Three "model dairies" near the city sell their product for 7 cents per quart in summer and 8 cents in winter. Within the eity limits there are 50 dairy herds, including 250 hearl. About 500 dairy farms send milk into the city.

A city ordinance of twelve sections, adopted and amended in 1897, regulates the city milk supply. Any person selling milk must have a license for each establishment or vehicle. Every person delivering milk by hand "jin quantities less than 1 gallon to each customer" shall wear upon his vest a small shield bearing the number of his license. Licenses are issued ammally ly the mayor and cost sl each. Adulterated milk, milk from eows fert on fermenterl or other unhealthy ford, milk produced in places where any contagions direase is known to exist, or any milk that does not come up to the legal standard of 12.5 per cent total solich, :3 per cent fats, and a specific gravity between 1.029 and 1.033 at $60^{\circ} \mathrm{F}$, is prohibiterl. Skimmer milk may be sold if the packages are plainly labelex and if it has a specific gravity at $60^{\circ} \mathrm{F}$. between 1.032 and 1.037 .

The city expends $\$ 1,000$ annually in connection with the supervision of its milk supply. One oflicer, an inspector, gives his entire attention to the work and one chemist part of his time. During the past year 1,219 samples of milk were examined ly lactometer and the Babock test, a part of them heing analyzed gravimetrically and 850 of them being examined for preservatives; 12 bacteriological examinations were made for typhoid and tubercle bacilli; and one-half the city herds were inspecterl. In the two years enderd June 30,1900 , 6si samples of milk were examined for preservatives and $4: 3$ of them were fomel to contain formaldehyde and 9 boracie acid. The milk inspeetor reports the results of the examination for fat and specific gravity of several samples of milk from different breeds and a few samples of fore milk and strippings. 
The greatest recent improvement has been in the composition of the milk. There should be more thorough inspeetion of dairies, veterinary examination of all milch cows, and more care in the handling of the milk supply hy producer, middleman, and retailer. Care should be taken not to license a dairy that is not calpable of producing good milk.

\section{Grand Rapids. (Population, 87,565.)}

[For comparison with other eities in Clasy II, see p. 30.]

George F. Richardson, milk inspector.

The daily consumption of milk is estimated as 5,000 gallons, or 0.46 pint per capita, besides 500 gallons skimmed milk and 200 gallons of rream. Milk is sold from 51 licensed stores and 22.28 wagons. Alout :2) per cent of the retail trade is supplied in glass bottles, and these are filled mostly at the producing farms. The retail price of milk is 5 cents per quart in summer and 6 cents in winter, the producers on the farms receiving 2 cents in summer and 2 to 3 cents in winter. The milk from 7 well-conducted dairies near the city is sold for 6 to 8 centes per quart throughont the year. There are ahout 1,000 milch cows within the city limits, and milk is sent in from ess licensed dairy farms. Alwont 5 per cent of the supply is shipped into the city by railway, the longest shipment being 100 miles.

An ordinance arlopten in October, 1897, and amended in November, 1897, refers to milk. Licenses for the sale of milk, issued annually, cost as follows: One wagon, \$5; each additional wagon, \$2; hand carts, \$1; cans carried by hand, 50 cents; dairies and creameries, 55; private house, restaurant, etc., 81 . But any farmer selling only the milk from his own cows is licensed free. Dairies and dairy herds furnishing milk must be inspected hefore license is granted. The use of the tuberculin test is anthorized. Adulterated, ete., milk is prohibited. The milk standard is 12.5 per cent total solids, 3 per cent fat, specific gravity at $60^{\circ} \mathrm{F}$. between 1.029 and 1.033 . Skimmed milk must be plainly labeled.

Ordinance section regarding milk license fees is given in Appendix I (1. 17s).

Alout $\$ 1,600$ is expended amnually in the supervision of the milk supply. Two officials-an inspector at $\$ 800$ and an assistant at $\$ 600$-give their entire time to this work. During the past year 1,500 samples of milk were examined by the Babcock test for butter fat, and the Westphal balance for specitic gravity; no bacteriological examinations were made; all the city cows and all the dairy farms were inspected.

Recent improvements include better methods in the are of "ows; greater cleanliness in dairies, and proper aeration and cooling of milk. It is helieved an organization of milk producers and dealers should be effected to promote the common interesty encourage better methods, etc.

Saginaw. (Population, 42,345.)

No reply to inquiries was received.

\section{Bay City. (Population, 27,628.)}

[For comparison with other cities in Class III, see p. 36.]

W. H. Gilbert, milk inspector.

Daily consumption of milk is estimater as 3,000 gallons, or $0.8 \bar{t}$ pint per capita. Milk is sold from 8 stores and 28 wagons. Within the city limits there are 3 herds, including 40 cows, besides private cows kept for family use, 1 to 3 in a place. Milk is sent in from about 27 dairy farms within 6 miles of the city.

An ordinance adopter in May, 1898, regulates the sale of milk. Dairies and dairy herds supplying milk must be inspecter previous to the issuing of licenses. License fee $\mathrm{for}$ the sale of milk is as follows: From wagons, $\$ 10$ earh; hand 'arts, $\$ 3$; hand peddlers, \$2; dairies or cremeries, \$5; restaurants, etc., \$2; private housen, $\$ 1$ for 
each cow. Dairmen outwisle the city furnishing nilk for city pededlers pay no license fee. The sale of adulterated, ete., milk is prohibited. Bottles ased in the delivery of milk or crean must he sterilized, and the milk and crean aerated and cooled previous to bottling. The milk standard is 12.5 per cent molids, 3 per cent fat, and specific gravity at $60^{\circ} \mathrm{F}$, between 1.029 and 1.033 . Skimmed milk containers must be labeled.

During nine months in 1900, 168 samples of milk were examined by the Babcock test, no bacteriological examinations were made; all the city herds and all the dairy farms were inspected.

\section{Jackson. (Population, 25,180.)}

[For comparison with other cities in Class III, see p. 36.]

\section{J. C. Harter, food and sanitary inspector.}

The daily consumption of milk is estimated as 1,745 gallons, or 0.55 pint per capita. This is sold from 60 stores and 5: wagons. Nearly all the milk is delivered in glass bottles which are filled at the farms. No milk is pasteurized. The retail price of milk is 5 cents per quart throughout the year, producers receiving 2 cents in summer and $2 \frac{1}{2}$ cents in winter. About one-half the dairies are said to be conducted in a satisfartory mamer, and one to be a "model." Within the city limits there are 8 herds, including 55 cows, and milk is brought to the city in wagons from 59 dairy farms, the longest haul being $6 \frac{1}{2}$ miles.

The city milk supply is under the supervision of the food and sanitary inspector. During the past year $2 ? 0$ samples of milk were examined by the Babcock test and gravimetric analysis; no bacteriological examinations were made; all the city herds and all the dairy farms were inspected.

\section{Battlecreek. (Population, 18,563.)}

[For comparison with other cities in Class IV, see p. 40.]

E. Cunningham, assistant milk inspector.

The daily consumption of milk is estimated as 1,400 gallons, or 0.60 pint per capita. Milk is sold from 4 stores and 26 wagons. All milk dealers deliver milk more or lexs in glass bottler, filled some at the farms and some in the city. A small amount of milk is pasteurized and the practice is increasing. The retail price is 5 cents per quart throughout the year, producers receiving 2 cents. Within the city there are 6 herds, and milk is brought in from 70 dairy farms within a radius of 9 miles,

An ordinance alopted in June, 1898 , refers to milk. License fee for retailing unilk is as follows: Milk wagons, \$5; hand carts, hand peddlers, stores, ete., \$2; each wagon after the first, $\$ 3$. Persons having one cow are exempt from license fee. The tubereulin test is authorized in the inspection of cows. Cows must be kept in good sanitary condition and be given wholesome food. Impure, arlulterated, ete, milk is prohibited. The milk standard is 12.5 per cent solids, :3 per cent fat, and specific gravity hetween 1.029 and 1.033 . Sperial license is required for the sale of skimmed milk and buttermilk, and their containers must be labeled.

One hundred and thirty dollars is expended annually in the supervision of the milk supply, one official giving a part of his time to this work. During the past year 560 samples of milk were examined by lactometer and Babcock test; all the city herds and all the dairy farms were inspected.

Recent improvement in the quality of the supply is due to greater cleanlinesis at dairies and the aeration of the milk. 


\section{Lansing. (Population, 16,485.)}

[For comparison with other cities in Class IV, see p. 40.]

\section{W. Crum, M. D., health officer.}

The daily consumption of milk is estimated as 1,000 gallons, or an avearge of 0.49 pint per capita, besides 100 gallons of skimmed milk and 25 gallons of cream. Milk is wolil from 3 stores and 22 wagons. Ahout one-third of it is delivered in glass botthes filled on the farms. Only a very small amount of milk is pasteurized, and the nractice is not increasing. The retail price of milk is 5 cents per quart throughout the year, producers receiving 2 and $2 !$ cents per quart in the two seasons. Within the city limits there are 3 herds, including 32 cows, and milk is brought in wagons from 45 dairy farms, the longest haul being 4 miles.

Nine hundred dollars is expenderl annually in the supervision of the milk supply, one official giving his entire time to this work. During the past year 41 samples of milk were examined by lactometer and Babcock test; 4 samples were examined for tubercle bacilli; all the city herds and all the dairy farms were inspected.

\section{MINNESOTA.}

IV. W. P. McConnell, State dairy commissioner, St. Paul.

Cieneral laws of 1899 , chapter 257 , amended, and chapter 295; and 1895, chapter 202 and chapter 203 , refer to milk, etc. It is the duty of the state dairy and food commissioner to enforce all laws relating to dairy products. Persons peddling milk in cities and towns having 1,000 or more population must, every May, procure a licen:e from the State commissioner at a cost of $\$ 1$ for each vehicle; and license nmmler, name, and business address shall be shown on vehicles. Stores, booths, aic., atre licensed at the same fee. Changes of drivers or other employees must be reported. It is unlawful to sell milk or cream from milk that is unclean, minwhlesome, or adulterated, or that has not been cooled or aerated, or to which preservatives or other substances have been added; or milk from cows kept in ('owrled, filthy, or poorly ventilated stables; or milk from cows having tuberculosis, uleers, or other disedse, or fed upon distillery waste or brewery grains, ete.; or milk from (ows less than 15 days before or 5 days after parturition. The milk standard is 13 per cent solids, $3 \frac{1}{2}$ per cent fat. The cream standard is 20 per cent fat. skinmed milk must he plainly labeled. Cans, bottles, ete, used in the transportation of milk over any railway or hoat line must be emptied before the milk sours, and then promptly cleaned. Ordinances not conflicting with State laws may be passed by the council of any city, providing for the inspection of milk, dairies; and dairy herds within the vity limits, and may require licenses (without fee) for selling milk; and inspectors, experts, etc., may be appointed for their enforcement.

The Penal Code, section 331 anended, provides that whoever adulterates milk with the intent of selling it as mululterated, or knowingly makes such a sale, is guilty of a misdemeanor.

Dairies numbering 1,025) have been inspected in 129 cities; between 200 and 300 lairies shipping milk to these cities are not inspected.

Forms for recording data regarding milk samples are shown in Appendix IV (1. 203).

\section{Minneapolis. (Population, 202,718.)}

[For comparison with other cities in Class I, see p. 26.]

W. D. McCall, milk and bread inspector.

The daily consumption of milk is estimated as 28,000 gallons, or 1.11 pints per capita. This large amount is explained by the common use of milk by the Soandinavian element. It is estimated also that 335 gallons of skimmed milk, 3,536 gallons 
of cream, and 200 gallons of huttermilk are consumed daily. Milk is sold from about 400 stores and 500 wagons. Only a small percentage of the milk is delivered in glass bottles and these are filled in the city. The trade in pasteurized milk is as yet unimportant. About half of the cream is pasteurizerl. The retail price of milk is 5 cents per quart in summer and 5 to 6 cents in winter, the producers receiving $2 \frac{1}{2}$ cents in summer and 3 cents in winter. Within the city linits there are about 2,500 cows, and perhaps half of them are kept by persons who have only 1 or 2 ; the total within a radius of 10 miles is 10,000 , inclurled in 450 herds. Outwide the 10 -mile radius there are 50 dairy farms sending milk into the city. One-fifth of the total supply of milk is received by rail, the longest shipment being 75 miles.

An ordinance to regulate the eity milk supply was passed by the rity council in 1895 and has since been amended three times (twelvesections). A lin'ense is required for the sale of milk; applicant must give detailed information regarding the management of the dairy whence his supply. The dairy must be inspected by a veterinarian acceptable to the health commission, and the animals must be examined for tuberculosis and other diseases. For the detection of tuberulusis the use of tuberenlin is authorized a; this is furnished by the health department free of charge. All inspected animals are tagged to show the presence or alnence of infections disease. Investigation of dairies is reported to the city comncil before decision as to issuing a license is made. The license is issued without charge; it extends until the first of the following May, but can be revoked for cause. The sale of impure milk or milk from unhealthy animals is prohibited. Cow within the city must be kept clean, and they must not be fed on hrewery grains or other food which will cause the milk to be unhealthy, and their drinking water must be pure. No foreign matter shall be added to milk, nor shall any constituent be removed; it must contain 13 per cent solids and $: 32$ per cent fat. Skimmed milk may be sold if in a vessel plainly labeled.

About $\$ 5,000$ is expended annually for the supervision of the city milk supply. Three officers give their entire time and 2 part of their time to this work; these include 1 veterinarian, 1 chemist, 1 milk inspector, and 2 dairy inspectors. During the past year 3,022 samples of milk were analyzed by the Babcock test and by gravimetric analysis; a few samples were examined hacteriologically; 92 of the city herds and 99 dairy farms were inspected; $1,516 \mathrm{milk}$ dealers were warned that their milk must be improved, 5 were convicted and fined for watering their milk, 1 was convicted for selling without a license, and 1 firm was convicted and fined for selling a preservative.

In the year $1900,4,450$ cows were tested with tubereulin and only 79 were condemned; this was 1.78 per cent as comprared with 9 per cent in 1895, when the use of tulnereulin was inangurated. During the year 43 (oows were retested; 33 of them reacted and were condemned.

The form for notice to milk dealers to display license number on delivery wagons is shown in Appendix IV (i). 00).

The most marked recent improvement is shown by the increased willingness on the part of dairymen to have their herds inspected. More well-trained inspectors are needed for the proper enforcement of the law.

\section{St. Paul. (Population, 163,065.)}

[For comparison with other cities in Class I, see p. 26.]

W. W. P. McConnell, State dairy and food commissioner.

The daily consumption of milk is estimated as 12,000 gallons, or 0.59 pint per capita, besides about 1,500 gallons of skimmed milk and 1,200 gallons of cream. Milk is distributed from 400 stores and 325 wagons. (ilass bottles are ured in the

"The right to use tuberculn was contimed by the supreme court of Minnesota. 
denvery of ahout one-seventh of the supply, and these are filled in the eity. Ten per cent of the milk is pasteurized, and this treatment is increasing. The retail prive of milk is 5 cents per cuart in summer and 6 cents in winter, the producers receinng 13 to 2 ents in summer and $2 \frac{1}{4}$ to 4 cents in winter. There are no "model dairies" in the vicinity. Within the city limits and within a rarlius of 10 miles there are 300 dairy herds, including 6,600 head; 30 other dairy farms send milk into the city. About 20 per cent of the milk supply is received ly rail, the longest shipment being 75 miles.

City ordinance No. 2042, April, 1899, regulates the milk supply. Every person selling milk is required to hold a license, applisation for which must be accompanied ly a statement giving certain information rearaling location, soure of milk supply, etc. Sale may commence after application is filed and may continue moss license is refused. The dairy must he examined hy an inspector, special attention being given to the health of the attle, each one being tagged to show its condition. A charge of 50 cents per aninal is made for inspection. If the inspector's report is favorable, the license is issued, to be effective one year; license number must appear in milk stores and upon delivery wagens. The use of the tubereulin test is athorized. The sale of arblteraterl or unwholesome nilk, milk taken from diseased or unclean cows, or cows ferl on fermented hrewery grains or distillery waste, or given impure water, milk kept in unclean veswels or in unsanitary surroundings, or milk containing a preservative, is prohibited. The milk standard is 13 per cent solids, 32 per cent fat. Skimmed milk nay be sold if in rexsels plainly labeled. Cows within the city limits must not be overerowded or kept in badly ventilated stables.

The city expends annually about $\$ 2,000$ for the improvement of its milk supply. No one official gives his entire time to this work, but varions employees of the health department are detailed from time to time. During the past year more than 500 samples of milk were examined hy the Babeock test, and those that did not come "1p to the required standaril weresuljected to gravimetric analywis; no bacteriologieal examinations were made; all of the producing dairies were inspected, many cows being examined for tuberculosis.

Lately special attention has been given to the better feeding of the cows, and proper aeration and refrigeration of the milk. Needed improvements include better sanitary conditions, greater care in handling milk, and thesterilization of all milk utensils. It is proposed to have the State provide for the payment for mileh cows condemned by the city authorities on account of tuberculosis or other diseases.

\section{Duluth. (Population, 52,969.)}

[For comparison with other cities in Class II, see p. 30.]

W. IV. P. McConnell, State dairy and food commissioner.

The daily eonsmuption of milk is estimated as 4,000 gallons, or 0.60 pint per capita, besides 100 gallons of skinmed milk and 225 gallons of cream. Milk is sold from 45 stores and 95 wagons. About "3 pere cent of the total supply is delivered in glass jars which are filled in the eity. No milk is pasteurized. The retail price of milk is 5 cents per quart in summer and 6 cents in winter, producers receiving about $13 \frac{3}{4}$ cents in summer and 21 cents in winter. The product of one small "model dairy" is sold for 7 cents per quart throughout the year. Within the city limits there are about 100 dairy herds, including 1,100 cows, and milk is sent in from about 45 dairy farms in Minnesota and 20 in Wisconsin. About 33 per cent of the total supply is received by railway, the longest shipment being 155 miles.

The milk supply is regulated by State laws.

One official is detailed from the State dairy and food commission to Duluth and vicinity to inspect dairies, dairy cattle, milk, and other food supplies. For this work an annual salary of $\$ 1,200$ is paid. During the past year 400 samples of milk 
were examined by the Babcock test; no bacteriological examinations were made; all the herds in the city and all the dairy farms except those in the aljoining state were inspected.

Recently there has been a marked improvement in the character of the milk supply, due to an increased interest on the part of producers in fumishing a pure article. Suggested improvements, as given, are the refrigeration of milk buring railway transportation and the inspection of milk and cream shipped from the farms out of the State.

\section{MISSISSIPPI.}

This State has no milk law.

\section{MISSOURI.}

Laws of 1891, page 163, empowers cities and towns "to license and regulate milk dairies and the sale of milk, and provide for the inspection thereof."

The supervision of market milk is left entirely to local anthorities.

St. Louis. (Population, 575,238.)

[For comparison with other cities in Class I, see P. 26.]

Henry J. Helwig, M. D., milk inspector.

The daily consumption of milk is extimated as 26,375 gallons, or 0.37 pint per capita, besides 3,000 gallons of cream. To skimmed milk is userl. Milk is solil from 1,987 stores and 1,109 wagons. In the delivery of milk, glass buttles are generally used, the greater part of them being filled in the city. Very little milk is pasteurized and there is no increased demand for this treatment. The retail price of milk is 5 cents per quart when delivered from the can am as high as 8 cents when in glass bottles, the producers receiving 2 to 23 cent, the price per cuart varying aceording to the percentage of butter fat. Three dairies in the vicinity conduct their business in an especially satisfactory manner, and are paid at high as 12. centes per quart for their product. Within the eity limits there are 400 herds, includines about 8,000 cows, and milk is sent into the city from 119 dairy farms.

Ordinance No. 2n808, August, 1902, regulates the city milk supply. License to sell milk and eream at retail is $\$ 1$, in addition to a semiannual license of $\$ 2.50$ for each delivery rehicle; license to sell at wholesale is $\$ 25.5$. The sale of impure, arlulterated milk, milk from diseased cows, milk containing any foreign substance, or milk from cows within tifteen days before or twelve days after "alving is prohibiterl. The milk standard is solids, 11.5 per cent; fat, 3 per cent. Cream must not contain less than 12 per cent fat. Skimmed milk (all milk containing less than 10.5 per cent total solids and 1.5 per cent fat.) may besold if in properly labeled containes's and if the "Skimmed Milk" sign is displayed on wagons and in stores from which it is sold. Condensed milk must be made from pure milk. Dairies where milk is produced for use in the city must be inspected at least once a month under the direction of the eity chemist. Mileh cows must be free from disease. ('ares of sickness of persons or animals on dairy farms must be reported. Milk must not be exposed to contagious diseare, and must be cooled down to $45^{\circ} \mathrm{F}$. and maintained at or below $50^{\circ} \mathrm{F}$. until delivered to customers. The inspectors must give bonds to faithfully perform their duties and are given the usual anthority to enter dairy premises to make inspection.

The city expends annually for the supervision of the milk supply $\$ 1,850$, and 1 inspector gives his entire time to the duties of the office. I mring the yoar, 6\$4 samples of milk were examined by lactometer and the Babook tent, and $7: 2$ bacterological examinations were made for typhond hacilli. About seven-eighths of the herds 
within the city limits were inspected. It is admitted that the law is not well enforcerl. Many of the city dairies are said to we brewer's grains and to be kept in an insanitary condition, and a considerable portion of their cows are believed to be tuberculons.

The composition of the milk has recently improved. There is great need for a State sanitary ofticer to inspert dairies and dairy herds and to see that they are kept in good sanitary condition.

\section{Kansas City (including Kansas City, Kans.). (Population, 215,170.)}

[For comparison with other cities in Class I, see p. 26.]

R. H. Hodges, meat and milk inspector.

Population: Kansas ('ity, Mo., 16.7,752; Kamsas (ity, Kans, 51,41s-total, 215,170.

The daily consmmption of milk in the two cities is estimated as 25,000 gallons, or 0.93 pint per capita, hesides some skimmed milk and cream. Milk is sold from 400 stores and 420 wagons. Glass bottles are used by one large concern and they are filled in the city. Trade in pasteurized milk is unimportant. The retail price of milk is 5 cents per quart in summer and $5_{4}^{3}$ cents in winter, the producers on the farms receiving $2 \frac{1}{2}$ cents per quart in summer and 3 cents in winter. Two or three specially well-conducted dairies near the city sell their product for 6 cents per quart throughout the year. There are 40 herds, including 700 cows, within the city limits. and about 240 dairy farms send milk into the city. One-tifth of the total milk supply is received by railway.

Sections of the "Revised ordinances of Kansas City of 1898 ," referring to the milk supply, are Tos. 1015 to 1020, 1023, 1029 (amended by ordinamce 11,179, Mareh, 1899), and 1030 to 10:35. License is required for the sale of milk or cream, and its number amb date of expiration must be sheswn upon delivery wagon. Persons selling milk must furnish to the hoard of health a list of their supplying dairies, with a statement showing the location of stables, pastures, etc. The sale of milk or cream that is impure, adulterated, or preserved, or from a cow condemmed by the health officer, is prohibited. Rexuired standards are, for milk, 3 per cent fat; huttemilk, ¿ per cent solids not fat; skimmed milk, 9 per cent solids not fat. Skimmed milk must he in a vessel plainly labeled, and when sold at retail a gummed label bearing the words "skimmed milk" must be attached to each veswel into which it is placed. Sperial attention must be given to milk, cream, and buttermilk served at hotels, ete. A thorough inspection must he made eree y two months or oftener at all places where milk is profuced for sale in the city, careful attention being given to the pastures. feeds, health of the cows, and sanitary conditions. If improvements directed are not made the sale of the milk is stopped. The manufacture, sale, or use in milk of any compound for the purpone of adulteration or prevervation is prohibited. Informers are entitled to one-third of fines collected.

Ordinance section regarding inspections of dairies, etc., is given in Appendix I, (p. 179).

Abont $\$ 2,500$ is appropriated amnually for the supervision of the milk supply. One inspector and one chemist give their entire time to this work. During the past year 2,500 samples of milk were examined by the Babeock test, and deficient samples by gravimetric analysis; 125 bacteriological examinations were made for tuberele bacilli; and all the dairy herds within the city and 200 of the 240 dairy farms were inspected.

Recent improvements in the milk supply are due to the almost entire abolishment of preservatives, to an increase in the percentage of butter fat, and to better refrigeration of milk in transit. Needed improvements include advancement in the price of pure milk, enforeement of the law, and legislation regulating the equipment and conduct of dairies. 
St. Joseph. (Population, 102,979.)

[For comparison with other cities in Class I, see p. 26.]

H. N. Keener, M. D., clerk of board of health.

The daily consumption of milk is estinated as 8,562 gallons, or 0.66 pint per capita, besides 4,290 gallons skimmed milk and 100 gallons cream. Milk is sold from 30 stores and 125 wagons. Little if any milk is delivered in glass jars. A small amount is pasteurized under the directions of physicians for special cases. The retail price of milk is 5 cents per quart in summer and $6 \frac{2}{3}$ cents in winter, the producers receiving 21 cents per quart in summer and $2 \frac{3}{4}$ cents in winter. There are no "model dairies" in this vicinity. Within the eity limits there are $6 \mathrm{~s}$ dairy herk, including ahout 1,000 head, and just ontside there are 25 dairies; but the exact number of dairy fams sending milk into the eity is unknown. One-eighth of the total nilk supply is received by rail, the longest shipment being 50 miles.

The ordinance regulating the milk supply recuires every milk and cream dealer to have a license, costing $\$ 15$ per year, and every person selling milk from only 1 cow to have a license costing $\$ 2.50$. Every milk dealer must register his license, tongether with the names and ahlresses of persons supplying him with milk. The legal standard for milk is 12 per cent solids, 3 per cent fat. Skimmed milk is permitted if purchasers know its character. Informers are entitled to one-third of the fines collected.

No definite fund is appropriated for the supervision of the milk supply, small amomnts being set aside at intervals for this purpose. There is no official milk insperetor, the bittle work performed heing done by an officer of the board of health. During the past year only bamples of milk were examined by lactometer; no examinations were made for bacteria; 12 of the 68 city herds and 18 dairy farms were inspeeted.

Demand for a better milk supply is responsible for some recent improvement. Needed improvements include thorough inspextion of all dairy herds supplying milk and the enforcement of the milk ordinances.

Joplin. (Population, 26,023.)

[For comparison with other cities in Class III, see ]. 36.]

J. II. Spencer, mayor.

It is elaimed that 50,000 people in and near the rity are supplied with milk. The daily (onsumption of milk is estimated as :3,500 sallons, besides 50 gallons of skimmed milk and 25 grallons of (ream. (On the hasis of the larger jonplation the average consumption of milk would be 0.56 pint per apita. Milk is sold from 21 stores and 32 warons. Cilase bottles filled at the farm are used by one concern in the delivery of milk. The retail price is 5 cents per quart throughout the year. There are 5 especially well-conducted dairies, and their milk is sold at the regular price. There is only 1 dairy herd (25) (ows) within the (ity linits. Milk is sent in from 202 dairy farms, the most distant one being 20 miles from the city.

The city has no milk ordinances.

Nothing is expended by the eity for the supervision of its milk supply. During the past year no samples of milk were examined for composition, but the State veterinatian examined nearly all the herds which produce milk for the city and found no tuberculous cows.

\section{MONTANA.}

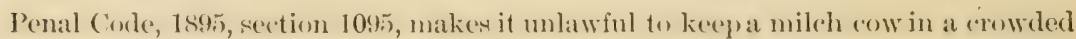
or unhealthy place or in a diseased condition, or to feed such cow upon any food that produces impure or unwholesome milk. 
Laws of 1901, page 66, refer to the sale of milk. It is unlawful to sell arhulterated milk-milk containing any ahled foreign substance, or milk from a diseaked dow. In cities having a population over 5,000 the milk and meat invpertor must he a grarkuate of a reterinary medical college. He must inspect, at least once a month, all dairies supplying milk, and cows must be subjected to the tuberculin test. In cases where they are free from disease, certificates of health are given. Milk must not he exposed to infection from persons having a contagious discase. Milk utensils, etc., must be kept clean. The milk standard is 12 per cent solids, :3 per cent fat, and a specific gravity not less than 1.025 .

\section{Butte. (Population, 30,470.)}

[For comparison with other eities in Class III, see p. 36.]

J. H. Cronin, sanitary inspector.

It is stated that 75,000 people in and near the city are supplied with milk. The daily consumption of milk is estimated as 7,000 gallons, lesides 1,000 gallons of skimmerl milk and 100 gallons of eream. ()n the hasis of the larger population, the average consumption of milk would he 0.75 pint per capita. Milk is sold from 12 stores and 35 wagons. About 2 per cent of it is delivered in glass bottles; none is pasteurized. The retail price of milk is 10) cents per quart and cream 40 cents per quart. There are no dairy herds within the city limits. Milk is sent in from 35 dairy farms, the most distant one being 12 miles out. Only 250 gallons is recerverl daily by railway.

A part of the time of one ofticial is given to the supervision of the city milk suplly. During the past year:350 samples of milk were exanined by the Batrock test. No bacteriologieal examinations were marle. All the dairy fams were inspecterl.

\section{NEBRASKA.}

S. C. Bassett, deputy State food commissioner, Lincoln.

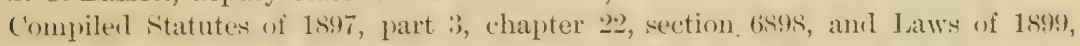
chapter 35 , sections 1 to 4 , refer to milk, ete. It is the duty of the state ford commission, assisted by county attorneys, to enforce laws relating to milk and cream, and it may exercise control over milk and cream testing. No person shall, with intent $\mathrm{t}$ ) defraud, sell milk that is anlulterated or skimmed, or from a diseasorl animal. Under anthority of the law the commissioner has establishert the following standards: Milk, 3 per cent fat; cream, 15 per cent fat.

(ieneral laws of 1897 , chapter 99, forbirl the sale of atulterated foul, whirh term is defined at length.

The State food commission has been unable to give any attention to the subject of market milk.

\section{Omaha. (Population, 102,555.)}

[For comparison with other cities in Class I, see p. 26.]

L. K. Hutton, milk inspector.

The daily consumption of milk is estimated as 5,740 gallons, or 0.45 pint per capita, besides 200 gallons of skimmed milk and 140 gallons of cream. Milk is sold from 146 stores and 150 wagons. Glass hottles are used in the delivery of about one-fifth of the milk supply. It is estimated that 300 gallons of milk is pastemrized, and the demand for milk so treated is increasing. The retail price of milk is 5 cents per quart in smmmer and 6 cents in winter. Within the dity limits there are s! herds, including 2,000 cows. Nearly one-third of the total anomnt of milk wiserl is receiver by railway, the longest shipment being 75 miles.

The ordinance regulating the sale of milk consists of thirteen sections. I license 
is reyuired for the sale of milk or cream, the fee heing $\$ 10$ per year for each store or wagon, but persons having less than 10 cows, and delivering by hand from a residence are rewuired to pay only si per cow, and persons selling less than 10 gallons of milk per day from a store are required to pay $\$ 5$. All licenses expire June 30 or December :31. Application for license must be accompanied by a statement giving rertain general information. Drivers and employees must hold certifieates from the board of health, there to be renewed the same as licenses. Milk wagons must carry a tin plate furnished free by the license inspector and showing license number. The orlinance forbids the sale of milk or cream which is melean, impure, arlulterated; from diseased cows or cows kept in an unclean place, or fed on distillery or brewery refuse, etc.; milk or cream which has been exposed to infection from a sick person or animal; milk from cows within fifteen days before or eight days after calving. The milk standard is 12 per cent total solids, 3 per cent fat. The cream standard is 16 per cent fat. Skimmed milk is permitted if plainly labeled. The milk inspector whall inspect all cows, dairy comblitions, etc., where milk is problueer for sale in the city. Cases of sickness on dairy farms shall be reported to the board of health. Distillery slops or refuse shall not be kept on dairy premises.

About $\$ 1,200$ is expended annually in the supervision of the city milk supply. One ins jector gives his entire time to this work. During the past year t60 simples of milk were examined by the Babcock test; all of the dairy herds in the city and 15 dairy farms were inspected.

Marked improvements have been shown in the way of cleanliness in the production of milk. Teeded improvements, as stated, include the inspection of dairy herds and premises by a competent veterinarian; the whitewashing of barns; and the delivery of milk in sealed packages.

\section{Lincoln. (Population, 40,169.)}

[For comparison with other cities in Class III, see [. 35.]

Thomas H. Pratt, city clerk.

The daily consumption of milk is estimated as 3,000 yallons, or 0.60 pint per capita, besides 2,000 gallons of skimmerl milk and 200 galloms of eream. Milk is sold from 25 stores; the number of wagons is not known. Five dealers deliver milk in glass bottles, some of which are filled at the farm and some at milk depots. The retail price of milk is 7 cents per quart in summer and 8 cents in winter. Four dairies near the city are conducted in a manner much superior to all others, but their milk is not sold at an extra price. There are no dairy herds within the city limits. Milk is sent in from farms within a radius of 6 miles.

The eity has no milk ordinances or regulations.

Nothing has been expended in the supervision of its milk supply, and no examinat tions of milk samples or inspections of dairies have been made.

\section{South Omaha. (Population, 26,001.)}

[For comparison with other cities in Class III, see p. 36.]

Frank E: Jones, milk inspector.

The daily consumption of milk is estimated as 1,108 gallons, or 0.34 pint per capita, besides 30 gallons of skimmed milk and 60 gallons of cream. Milk is sold from 2 stores and 27 wagons. About 5 per cent of the milk is delivered in glass bottles, filled at the farms. At present no milk is pasteurized. The retail price of milk is 5 to 6 cents per quart in summer and 6 cents in winter, the producer receiving $3 \frac{1}{2}$ to 4 cents in summer and 4 cents in winter. The milk from 2 dairies, conducted in a very satisfactory manner, commands the highest price. Within the eity limits there are 4 herds, including 71 cows, and milk is sent in from 202 dairy farms. One dealer receives milk by railway, the longest shipment being 30 miles. 
The milk orilinance of Marh, 1sig, regulates the sale of milk. The milk standard is 12 per cent solids, 3 per cent fat, specific gravity, 1.027 to 1.035 , and cream must have 16 per cent fat.

The city expends annually ahmut $\$ 1,000$ in the supervision of its milk supply, the milk inspector giving his entire time to this work. During the past year 411 milk samples were examined by the Babork test and lactometer. No hacteriological examinations were marle. The city herds were inspected monthly, and all the dairy farms were inspected.

\section{NEVADA.}

General statutes of 1885 , sections 4801 to 4809 , refer to milk, etc. County milk inspectors shall be appointed by the board of county commissioners. It is unlawful, knowingly, to sell adulterated or unwholesome milk or milk from cows fed on distillery, brewery, or hotel waste, called "swill," or impure matter from stalls or stahles. Skimmet milk may be sold as such. (ows producing market milk must not be kept in a crowded or whealthy condition nor given ford that will produce impure milk.

\section{NEW HAMPSHIRE.}

P'uhlic statutes of 1s!91-chapter 127, amented, refers tomilk, ete. Boards of health of cities and selectmen of towns are placed in charge of the inspection of milk, skimmed milk, and cream, and may appoint insperctors to attend to this work. No inspector shall be paid for his servioes unless he is a registered chemist or holder of a certificate from the dairy department of the state agricultural college. Chiefs of police or county sulicitors shall prosecute offenders. A license for the sale of milk, skimmed milk, and cream is required in all cities and towns having milk inspertors. Such license will be iswed to any person who shows that he understands the business and gives reasonahle assurance that the enws from which his milk is taken are healthy, pruperly ferl, ete. The license costs \$2, expires the first of each Jume, and is revoeable for cause. Its number and owner's name must be shown on delivery rehicles and in stores. It is unlawful to sell any milk, skimmed milk, or cream that is arlulterated or unwholesome, or contains a coloring matter or preservative, or milk from cows diseased or ferl on refuse of hreweries or distilleries or other suhstance which may be deleterious to their product. Milk standard, Oetoher to March, is 13 per cent solick, 9.5 per cent solids not fat, 3.5 pere cent fat; April to september, 12 per cent wolids, 3 jer" cent fat. Skimmer milk standard is 9 per cent solids not fat. The sale of milk that has heen skimmed is prohibited, except from ressels plainly marked. Milk shall be sold hy wine measure, and all measures used in selling milk shall have their capacity marked upon them. Milk tests by inspectors and for apportioning pay. ments must be accurate and marle by perons holding certificate of competency.

\section{Manchester. (Population, 56,987.)}

[For comparison with other cities in Class II, see p. 30.]

Joseph H. Geisel, milk inspector.

The daily consumption of milk is estimated as 4,000 gallons, or 0.56 pint per capita. This is sold from 100 stores and 115 wagons. Almost all the milk is delivered in glass buttles, some of which are filled in the city and some in the country. Very little milk is pasteurized. The retail price of milk is 5 cents per quart in summer and 5 to 6 cents in winter, producers receiving 21 to 3 cents throughout the year. There are no "model dairies" near the eity. There are no herds of milch cows in the city, Milk is sent in from 150 dairy farms, all being within a radius of 18 miles. 
State laws regulate the city milk supply.

Three humdred dollars is expended annually in the supervision of the milk supply, one inspector giving a part of his time to this work. During the past year 140 samples of milk were examined by the lactometer.

\section{NEW JERSEY.}

George IV. McGuire, chief inspector of foods and drugs, Trenton.

Public laws of 1894, chapter 317 ; 1893, chapter 207; 1891, chapter 210 and chapter 257 ; 1888 , page 461 , section 2; 1883 , chapter 68 and chapter 185 ; and an act approved March 21, 1901, refer to milk. The enforcement of the milk laws is charged to the chief inspector, under the direction of the State hoard of health. City boards of health shall require the registry of all cattle in the different cities, and may order inspections for disease when deemed necessary, and State officials may declare the prorluct of diseased animals unfit for use. $A$ commission is authorized to investigate and provide stfeguards against tuberculosis. Cows producing market milk must not be kept in a crowled or unhealthy place, or fed swill or any putrefying substance, etc. Milk must not be exposed to infection from persons having a contagious disease. Samples of milk shall be taken in duplicate, ete., and analyzerl at the State agricultural experiment station. Milk changed by the ardition of water or other substance shall not he sold in any eity of the first class. All cans and bottles in which skimmed milk is sold must be plainly marked. It is unlawful for any person to use a milk can belonging to another without his consent. The sale of food deemed to be impure aceording to numerous detailed definitions is forbidden.

Very few cities have taken advantage of the State laws regarding milk.

The form for reporting conditions at dairies and methods of handling milk is shown in Appendix IV, (p. 197).

The form for recording inspection of milk depots is shown in Appendix IV (p. 207).

\section{Newark. (Population, 246,070.)}

[For comparison with other cities in Class I, see p. 26.]

IVilliam H. Lyle, milk inspector.

The daily consumption of milk is estimater at 16,000 galloms, or 0.52 pint per capita, besides 1,200 gallons of cream and a small amount of skimmer milk userl by bakers. Nilk is sold from 800 stores and 279 wagons. About one-fourth of the supply is delivered in glass bottles, most of these heing filled at the producing farms. Little or no milk is pasiemrizerl. The retail prioe of milk is 6 cents per quart in summer and 7 cents in winter, and the producers receive 20 cents in summer and $3 \frac{1}{2}$ cents in winter. A few well-conducted dairies near the rity sell their product for 8 to 12 cents per quart throughout the year. There are in the city 58 herds, including 562 cows, hesides 312 cows in private stables. About 500 dairy farms send milk into the city. It is estimated that 60 per cent of the total milk supply is received hy rail, the longest shipment being 312 miles.

The sanitary corle ardopter by the city hoard of health in June, 188s, contains a few sections (XXYI, LX, LXVI, and LXVII) referring to the milk supply. An annual permit costing 10 cents is required for each animal kept within the city limits, but no license is necessary for the sale of milk. The law requires, also, that all stables and lots where animals are kept be in goul sanitary condition, particularly that all manures be removed and the premises kept rean and properly drained. Milk exposed where any communicable disease exists is prohibited.

The city expends anmally 82,000 in the supervision of the milk supply. One inspector gives his entire time, and the chemist and bateriologist of the board of health a part of their time to this work. I) nong the pas year 3,508 samples were 
examined by the lactometer, and 283 by the Babcork test and gravimetric analysis. No hacteriological examinations were made. Only the dairy herds within the city were inspected by city oflicials, those untside coming under the juriscliction of the State authorities.

Of the 283 samples of milk analyzerl, 185 contained more than 12.5 per cent total solids, 61 contained from 12 to 12.5 per cent total solids, and 37 contained less than 12 per cent total solids, the pouret showing 10.62 per cent. The lowest fat content was 2.4 per cent. As these samples were taken at random, the results of their examination may he understool to show fairly the composition of the entire supply. It is stater that the moral effect of taking samples promiscuously is goorl. It is the practice of the milk inspectors to take several samples at each place visited, only those suspected being taken in cluplicate. The following table shows the results of the analyses mate in 1900 (n)mbred with these mate in the three preceding years:

Number of samples analyzed.

\begin{tabular}{|c|c|c|c|}
\hline $18: 17$ & 1898 & 1899 & 1900 \\
\hline 136 & 178 & 221 & 283 \\
\hline 69. 12 & 70.222 & 72.40 & $65: 37$ \\
\hline 13.24 & 13.24 & 13.06 & 13.21 \\
\hline & $\ldots \ldots \ldots$ & 3.45 & 4.06 \\
\hline 21.32 & 14.15 & 15.38 & 21.55 \\
\hline 12.23 & 12,35 & 12.27 & 12.25 \\
\hline & $\ldots$ & 3. 60 & 3.56 \\
\hline 9.56 & 15.73 & 12.22 & 13.07 \\
\hline 11.61 & 11.58 & 11. 48 & 11. 56 \\
\hline & & 3. 11 & 3. 25 \\
\hline 12.87 & 12.82 & 12.75 & 12. 77 \\
\hline- & & 3.80 & 3.87 \\
\hline
\end{tabular}

Only two samples of milk were found to contain formaldehyde.

The details of the work performed in 1897 in connection with the supervision of the milk supply were reported as follows:

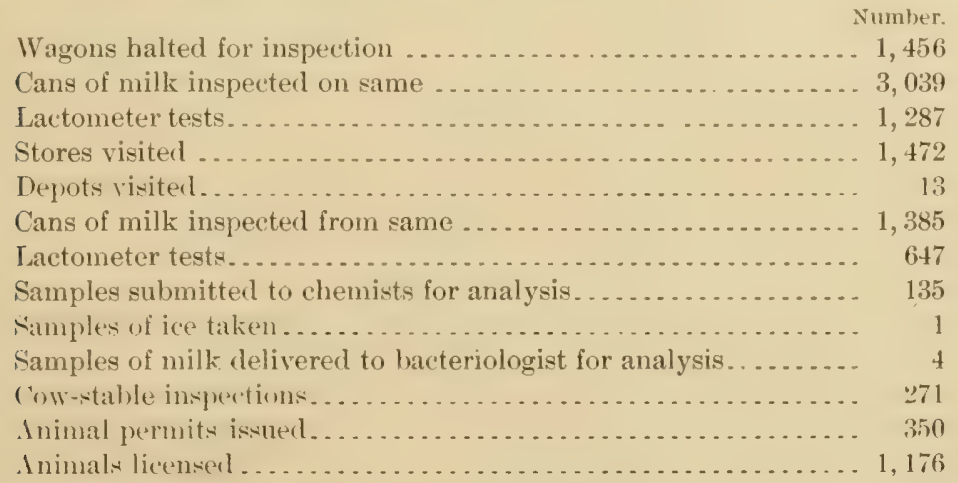

The health officer (alls attention to the fact that there has heen great improvement in the composition of milk since ten years ago, when samples below standard were frequently found to have less than 11 per cent total solids and sometimes as low as 7 per cent.

$25839-$ No. $46-03-8$ 
The forms for recording data regarding milk samples and the form for notification of the taking of a sample are shown in Appendix IV (pp. 205 and 206).

Neederl improvements include the enatment of a law requiring dealers to be licensed, and a more thorough and systenatic inspection of dairies and dairy products.

Reference is marle to a few dairies which produce milk of extra good quality and receive an extra price for it. Special mention should be marle of one of these, which for several years has heen operated in aceorlance with an agreement with a milk commission in Fssex County. This commission and its work are referred to on pages 173 and 174 of the Seventeenth Annual Report of the Bureau of Animal Industry. Undoubtedly it deserves aredit for the high quality of much of the milk sols in the vicinity of Newark, and much credit also for the establishment of milk commissions working along similar lines elsewhere.

The contract between the milk commission and the dairyman is shown in Appendix III (p. 182).

\section{Jersey City. (Population, 206,433.)}

[For comparison with other cties in Class I, see p. 26.]

D. W. Benjamin, M. D., health inspector.

John C. Tracy, assistant State dairy commissioner.

The daily consumption of milk is estimated as 12,000 gallons, or 0.47 pint per capita. No skimmed milk is used, but it is estimated that there are 500 gallons of eream consumerl daily. Milk is sold from 450 stores and 250 wagons. Glass bottles are used in the delivery of about one-half of the total supply, and these are filled, some on the farms, some at the stores, and some on the wagons. Only a little pasteurized milk is used. The retail price of milk is 6 to 8 cents per cyuart in summer and 7 to 8 cents in winter. There are no "morlel dairies" supplying milk to the city. Within the city limits there are 30 herds, including 275 cows; no data is available as to the number of dairy farms sending milk into the city. The greater part of the total milk supply is received by rail, the longest shipment being 250 miles.

The city authorities have made no provisions for the regulation of the milk supply, its supervision being left to the State.

During the past year about 500 samples of milk were examined by lactometer, and some of them by gravimetric analysis; no bacteriological examinations were made; all the city herds were inspected.

It is urged that a competent milk inspector shonld be appointed to work under the direction of the city board of health.

\section{Paterson. (Population, 105,171.)}

[For comparison with other cities in Class I, see p. 26.]

James P. MeNair, secretary of the board of health.

The daily consumption of milk is estimated as 8,000 gallons, or 0.61 pint per capita, besides 200 gallons of cream. The use of skimmed milk is not known to the authorities. Milk is distributed from 225 stores; the number of wagons is not known. About one-eighth of the milk is delivered in glass bottles, being the output of four dairy establishments, two in the city and two in the country. Very little milk is pasteurized. The retail price of milk is 6 to 8 cents per quart both in summer and winter, the producers receiving 3 to 4 cents per quart in summer and 3 to 5 cents in winter. There are two establishments near the eity, managed in an up-to-rlate manner, which sell their entire product for 10 cents per quart in summer and 12 cents 11 winter. Within the city limits there are 84 herdy, including 423 cows; the number 
of the dairy farms sending milk into the city is mnknown. It is estimated that 16 per cent of the milk is brought into the eity by rail, the longest shipment being 42 miles.

The city has no milk ordinances or regulations.

Nothing has been expended in the supervision of the milk supply, and no examinations of milk samples or inspections of country dairies have been made. The dairies in the city have been inspected.

Needed improvements include the appointment of milk inspectors, the repuirement that all milk dealers be licensed hy the board of health, and an ordinance establishing a standard for milk and regulating its sale and delivery.

\section{Camden. (Population, 75,935.)}

[For comparison with other cities in Class II, see p. 30.]

J. O. George, D. Y. S., food and milk inspector.

The daily consumption of milk is estimated as 4,000 gallons, or 10.42 pint per capita, besides 125 gallons of skimmerl milk and 100 gallons of cream. Milk is sold from 128 stores and 75 wagons. Two dairynen supply milk in glass jars, using alout 700 bottles daily; one fills his lottles in the city, the other at the producing farm. No milk is pasteurized. The retail priee of milk is 8 cents per quart throughout the year, producers receiving 3 to 3.2 cents in smmmer and $32 \mathrm{t}$ to 4 cents in winter. There are no herls of mileh cows in the rity, the milk heing sent in from 113 dairy farms. Almost the total supply in receiverl by railway, the longest shipment heing 30 miles.

About $\$ 1,200$ is expended annually in the supervision of the rity milk supply. One milk and food inspeetor and one chemist give a part of their time to this work. During the past year 550 samples of milk were examined by lactometer and by gravimetric analysis; a large number of tests were made for formaldehyde; no bacteriological examinations were made; and no dairy farms were inspected.

Recent improvement is due to the introluction of cow giving richer milk; better feeding; and a more careful handling of the milk. Neexled improwements, as given, include a thorough inspection of all milch cows for tuberculosis and better care of the milk.

\section{Trenton. (Population, 73,307.)}

[For comparison with other cities in Class II, see $\mathrm{y}_{0} 30$. ]

A. S. Fell, M. D., health officer.

George W. MeGuire, State dairy commissioner.

The daily consumption of milk is estimated as 4,500 gallons, or 0.49 pint per cappita. Milk is sold from 25 stores and 130 wagons. Fifty per cent of the total supply is delivererl in glass hottles, some of them being filled in the city and some in the country. No milk is pasteurizerl. The retail price of milk is 6 cents per quart in summer and 8 cents in winter, the producers on the farm being paid 3 cents in summer and 4 cents in winter. There are 3 well-conducted dairies near the city which reseive the regular retail price for their product. There is only one herd of cows in the city, and it includes 20 hearl. One hundred and fifty dairy farms send milk into the city. About 5 per cent of the total supply is received by railway, the longest shipment being 20 miles.

Nothing is expended hy the city in the supervision of its milk supply, this work heing under State control. During the past year 100 samples were examined by lactometer and gravimetric analysis; no bacteriologieal examinations were made; about 20 per cent of the dairy farms were inspected.

Recently the milk supply has been found to be practically free from preservatives, and has shown general improvement otherwise. 
Hoboken. (Population, 59,364.)

[For comparison with other cities in Class II, see p. 30.]

Antonio Granelli, health inspector.

The daily sales of milk are estimated to he 8,750 gallons, but these include some duplications, recording the same milk sold both at wholesale and retail. Consefuently the average raily per capita consumption is actually less than 1.21 pints, as would appear from the reports. Milk is sold from 243 stores and 24 wagons. The retail price of milk varies from 3 to 6 cents per quart in summer and $t$ to 8 ceents in winter.

An ordinance passed September, 1897, refers to milk. A permit costing $\$ 1$ is repuired for the sale of milk. Wilk vessels must be kept clean. Irblteraterl, impure, etc., milk is prohibited. The milk standard is 12 per cent solids, 3 per cent fat.

Nothing is expended by the eity in the supervision of its milk supply.

The inspector recommends that milk be shipperl from the farms in sealed packages.

\section{Elizabeth. (Population, 52,130.)}

[For comparison with other cities in Class II, see p. 30.]

John C. Tracy, assistant State dairy inspector.

The daily consumption of milk is estimated as 13,062 gallons, or 22 pints per eapita. No explanation of this apparently very large consumption of milk is given; it may be due to the fact that some milk is forwarled to other cities. No skimmerl milk is userl. Nlilk is sold from 25 stores and 50 wagons. Only a small quantity is delivered in glass hottles and these are filled at the prorlueing farms, and none is pastemizerl. The retail price of milk is 6 cents per quart in summer and 8 cent's in winter, producers receiving 3 and 4 cents in the two seasons. There are no "model dairies" near the city. Within the city limits there are 10 herds of milch cows, including 100 head, and milk is sent in from 55 dairy farms. A very small portion of the total supply is received by railway, the longest shipment being 5 miles.

An ordinance adopted in March, 1899, supplements the State laws. City cow stahles must he kept in a good sanitary comlition and be provided with underground manure vaults. Unwholesome milk is prohibited. Milk, when offered for sale, must not be misrepresented.

Nothing is expended by the eity in the supervision of its milk supply, this work being under state control. During the past year a number of milk samples were examined hy the lactometer; no bacteriologial examinations were marle; all the city milch cows and all the dairy farms sending milk into the eity were inspected.

Bayonne. (Population, 32,772.)

[For comparison with other cities in Class III, see p. 36.]

\section{A. C. Torman, health inspector.}

Abont 1,800 gallons of milk is used daily, which is an average per capita consumption of 0.50 pint. Milk is sold from 130 stores and 35 wagons. The farthest distance from which it is supplied is 40 miles. Four herds are in the city, including abont 125 cows.

The sanitary code of the board of health adopted in Narch, 1899, refers to milk. Milk venders must obtain a permit costing s.2. The sale of adulterated, ete, milk is prohibited. The milk standard is 12 per cent solids, 3 per cent fat.

There is no milk inspector and no samples of milk have been examined for composition, but all the city herds have been inspected. 
Atlantic City. (Population, 27,838.)

[For comparison with other eities in Class III, see p. 36.]

H. C. Beck, health inspector.

Milk is sold from 30 stores and 50 wagons. Glass bottles, filled mostly in the city, are used extensively in the delivery of milk. Little or mo milk is pasteurized. The retail price of milk is so cents per quart throughout the year, producers receiving 4 cents per yuart. There are a few well-eonducted dairies near the city, hut their product is not sold at an arlvance in price. The total milk supply is receiverl hy railway, the longest shipment being 50 miles.

Nothing is expented by the aty in the supervision of its milk supply, this work being under State officials.

Passaic. (Population, 27,777.)

[For eomparison with other cities in Class III, see I. 36.]

J. Payne Lowe, D. V. S., veterinary inspector.

The retail price of milk is 5 to 8 cents per quart throughout the year. The milk from one "model dairy" is sold at an atranced price. Within the city limits there are $4: 3$ herds, including 122 ("ows. ()ver two-thirds of the total milk supply is received by railway, the longest shipment being 100 miles.

The veterinary inspector gives a part of his time to the supervision of the milk supply. During the past year samples of milk were examined by the lactometer; no bacteriological examinations were mate; all the city herds were inspected, but none of the dairy farms.

It is urged that some provisions lee made by which health athorities in the districts where milk is promberl would report npon comblitions of herde, methods of handling milk, ete.

\section{New Brunswick. (Population, 20,006.)}

[For comparison with other cities in Class IV, see p. 40.]

Fenry R. Baldwin, M. D., president of the board of health.

The daily eomsumption of milk is estimated as 1,250 gallons, or an average of 0.50 pint pere "apita. Milk is sold from alyent:30 stores and :30 wagons. Ahout one-fifth is delivered in grlass hottles, am these are filled at the farm. Pastenrizerl milk is used only to a limited extent. The retail price of milk is 4 to 6 cents per quart in summer and 5 to 8 cents in winter, producers receiving 3 cents and $3 \frac{1}{2}$ cents in the two seasons. The milk from one "model dairy" is sold for 6 cents in summer and 8 cents in winter. Within the city limits there are 5 herds, including 70 cows, and milk is sent in from about 55 dairy farms, all within 6 miles of the city.

The city has no milk ordinance.

Nothing is alpropriated by the aity for the supervision of its milk supply. During the past year 3,500 samples were examined by the Babcock test, and 2 of the 60 dairy herds were inspected. The sale of milk from the well-enducted dairy belonging to the State agricultural college has had a marked effect in hringing about improvement in the city supply.

Recent improvement in the milk supply is due to better care and feeding of cows and to greater cleanliness of dairies.

Montclair. (Population, 13,962.)

[For comparison with other cities in Class IV, see p. 40.]

MI. O. Leighton, health inspector.

The daily consumption of milk is estimated as 860 gallons, or 0.49 pint per eapita. Little or no skimmed milk is sold. Milk is sold from 12 stores and 32 wagons. All the milk is delivered in grass bottles and almost all of these are filled at the farms. No milk is pasteurized. The retail price is 7 to 12 cents per quart throughout the year, prorlucers receiving 2 to 3.3 cents. The min from is "morlet dairies" is sold 
for 8 to 12 cents per (quart. Within the city limits there are 4 herds, including 35 cows, and milk is sent in from 24 dairy farms. About 20 per cent is received by railway, the longest shipment being 400 miles. Quite a large part of the supply comes from Chenango County, N. Y.

An ordinance adopted in March, 18!s, refers to milk. Persons selling milk must reginter with the board of health. ('ow stables must be properly leneated and constructed and be kept clean. Cow must be free from dangerous disease, be kept clean, and their udders washerl and wiped before each milking. Attendants must personally be clean and not exposed to contagions divease. Nilk must be removed to separate room at once after milking and be cooled in water. Nilk utensils must be washed in pure water and soda or soap, and be sterilized.

The milk ordinance is given in full in $\Lambda$ ppendix I (p. 175).

About $\$ 300$ is expended ammually in the supervision of the milk supply, two officials giving a part of their time to this work. During the jast year 166 samples of milk were examined by lactometer, Babock test, and gravimetric analysis; the same number was examinerl for bacterial content; all the rity herds and all the dairy farms were inspected each month. The results of chemical and bacteriological examinations of milk and accounts of conclitions found at dairies are published in the annual reports of the board of health, together with the names and addresses of the dairymen whose products and places are referred to. The reports are widely distributed, and real hy many citizens. The statement of the conditions found at one dairy is as follows: Large, light stable; goor drainage, and kept in excellent condition. ('enent floors and ilrops. Alout 20 eattle, reonlarly attended by a veterinarian. Milk conled over fatent conler and hottled immerliately. Ttensils sterilized with steam.

The supervision by the milk commissiom, referred to in the statement under Newark, extends to a portion of the milk sold in Montclair, and has had ensiderable effect in raising the standard of the supply of this city.

Recent improvements are due to the observance of better methods at producing dairies. Further improvement would undoubtedly follow if the actual facto in connection with different dairies were published in the newspapers.

In a paper upon "The importance of bacterial "ounts in the sanitary supervision of milk supplies" the health inspector presents, in an interesting manner, the results of his study of the subject. His investigations extented over a period of two or three years, and proved to his satisfaction that the sanitary condition of dairies can be safely judged hy the number of bacteria in the product. All the samples of milk which he examined in this comnection had heen bottled at the dairies, and so far as possible they were taken from the evening milking, their age, when examined, being twelve to fifteen hours; in some cases they were older. Regarding his experiments and conclusions he writes as follows:

"The time covered by the work is three successive years from September to June. The bacteria were grown upon gelatin, and each culture was allowerl to grow nearly to the point of liquefaction so that the slow-growing colonies would have all the time possible to increase to the counting size:

TABLE 1.-Average resulls.

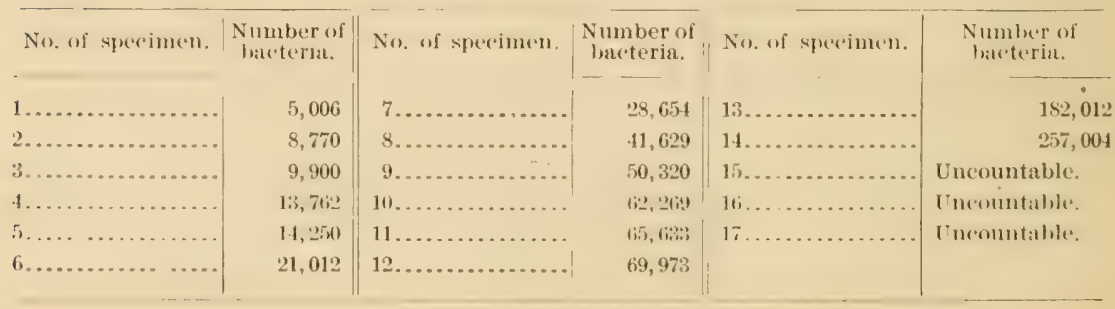


"Table No. 1 contains the average results of the determinations for each dairy during the whole term. Examination shows that the figures range from 5,006 in No. 1 to uncountahle in the last three; also that the list divides itself into three classes: Nos. 1-5, or those having a count helow 15,000; Nos. 8-12, or those running from 40,000 to 70,000 ; and, after a long interval, those dairies having an average of 180,000 and upward. Nos. 6 and 7 do not appear to be in any class, having a position intermediate hetween the first and second "lasses. A pussible reason for the eccentric position of these two dairies may be drawn from considerations which are to follow.

"Table No. 2 inclutes the results of the examinations which, taken togrether, make the averages for the dairies in the first class above described.

"The number of the dairy aceording to its succession is set at the top of the record of determinations, while the average in each case is set at the bottom.

TABLE 2.-First class; individual results.

\begin{tabular}{|c|c|c|c|c|}
\hline No. 1. & No. 2. & No. 3. & No. 4. & No, 5. \\
\hline 2,366 & 9,500 & 6,800 & 2,000 & 96,700 \\
\hline 5,800 & 1,900 & 6,400 & 4,200 & 7,700 \\
\hline 5,800 & 11,600 & 3,500 & 6,200 & 25,250 \\
\hline 5,000 & ${ }^{22}, 500$ & 2,200 & 12,700 & 12,900 \\
\hline 3,600 & 4,300 & 34,700 & 11,200 & 8,300 \\
\hline 2,800 & 6,300 & 2,800 & 8,800 & 2,000 \\
\hline 8,000 & 16,800 & 12,000 & 34,600 & 3, 600 \\
\hline 4,000 & 9,600 & 30,300 & 29,600 & 1,500 \\
\hline 3,400 & 13,500 & $10,9 C 0$ & . & 2,800 \\
\hline 3,500 & 8,000 & 7,600 & & 21,200 \\
\hline 6,700 & 13,300 & 1,600 & & 18,400 \\
\hline 5,800 & 17,600 & 3,800 & & 7,300 \\
\hline 5,800 & 600 & 7,300 & & 6,300 \\
\hline 5,450 & 700 & 8,700 & & 6,100 \\
\hline 6,600 & $3,6^{2} 20$ & & & 16,800 \\
\hline 4,600 & 3,620 & & & 6,800 \\
\hline \multirow[t]{4}{*}{5,100} & 11,560 & & & 8,600 \\
\hline & 9,840 & & & \\
\hline & 4,300 & & & \\
\hline & 5,300 & & & \\
\hline 5,006 & 8,770 & 9,900 & 13,762 & 14,250 \\
\hline
\end{tabular}

"Representing dairy No. 1 are the results of seventeen examinations, ranging from: 2,866 to 8,000 , and showing a remarkalble degree of uniformity thromghout. It is evident that whatever may be the conditions to produce these results, those conditions are miform. This seems to be exemplified, though less imperfectly, in the remaining columns of the table. Note in No. 2 that some of the determinations are lower than any in No. 1, but there is a wider range of figures, and some of the leterminations are above the 15,000 limit which marks this class. Nos. 3 and 4 are similar. No. 5 starts with the abnormally high count of 96,70 , but does not approach it again in the remainder of the list. It is evident that a remarkable change took place in the conditions within and surrounding this dairy after the first examination.

"Inspection of the dairies which these diagrams represent would show that Nos. 1, 2, and $t$ are very similar, and are of the highest type of dairy excellence. The stables are built upon elevated situations, where good drainage can bes secured. Inside the stables there is ample provision for light and ventilation, while the floors and manure troughs are built in such a manner and of such materials as will facili- 
tate cleaning. The atthe in these stahles are carefully groomed, for upon wholesome food, and regularly attended hy a veterinarian. The attendants employed are kept personally clean, and are provided with every facility for maintaining their cleanly condition throughout the inilking period. Of highest importance are the dairy houses in comnection with these first three establishments. In them are provided tight steam chests, in which all utensils necessary in the preparation of the product for the market are exposed to steam under pressure and thoroughly sterilized. The other principal features in connertion with the dairy homes are the coolers over which the milk flows as soon as it is drawn from the cows, from whence it goes to the bottler and is bottled immediately.

"Dairy No. 3 differs from the first two and the fourth only in this respect: The milk is raised hy different farmers in a clistrict, who sell it to a company which takes charge of the bottling and final delivery to the consumer. The condition of all branches of the process is, however, in no wise different in its sanitary and hygienic features from Nos. 1, 2, and 4.

"Dairy No. 5 differs from the first four in that the latter are the results of the expenditure of a large amount of money. There have been installed within them numerous devices to produce facility and comonny, as well as cleanliness in handling the product. From this it might be supposed that it is only in dairies of this character that we are able to procure low counts. Such, however, is not the case. Of course, it is easier to keep clean in a palace than in a hovel, yet it must ba admitted that cleanlines is not an imposibility even in the latter place. Inary No. 5 consists of low, old-fashioned stables, which at first glance exhibit nothing fatvorable, but within which close inspection will reveal the vigilanee of the owner. In spite of the mugh projections, innumerable (racks, and all the disadvantages common to combly stables, there are evidences of care and attention everywhere. The explanation to

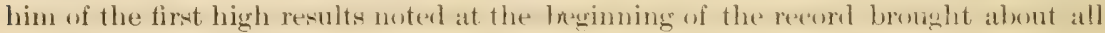
the alterations suggented. The owner is an ideal daingman in spite of his purerty.

TABLe 3.-Individual results.

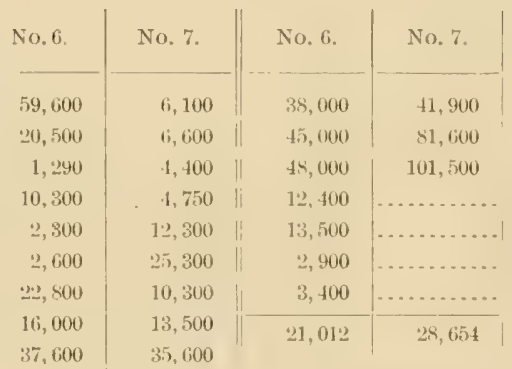

"Considering, now, the two dairies which were intermediate between the first and second classes, it will be seen that for dairy No. 6, in the table immerliately above, there are widely varying results, generally high am spasmolically low; a columm of figures without uniformity and with extremes which are bewildering when compared with the table of the first class of dairies.

"It has been observed that costly stables and expensive equipment are not indispensable for procuring clean milk and low bacterial counts. It is also true that the possession of all these does not insure the best results. Number 6 is a dairy which should belong to the first class, having clean, light, well-made stahles and carefully (rhosen attle, and a complete sterilizing and bottling equipment. It first thought it contradicts what has gone before, but if one should watch the dairy in operation 
for several days he would learn that the proprietors have many interests outside of the dairy inclosure, and are fond of many diversions. Consequently, the work is tow often left without their ane, and the employees, heing possessed of their full complement of human frailties, are not in good form at those times. Milking is done carelessly, cooling and bottling deferrent, and cattle go mugromed. Vigilanee there comes only in spasmodical waves.

"In dairy No. 7, Table 3, the list starts out very evenly, with low counts, which wonll, if continuerl, have placed the dairy well within the first class. The premises at dirst presented a neat, wholesone appearance, quite in keeping with the record mate at that time. Those who are acquainted with the owner know that he has experiences sormo in his family and alveraity in his worldly affairs; a man who has, moler the stress of this condition, beome careless and indifferent. The ready-made somm which this statement has is quite appreciable to the writer, yet these conditions do actually exist and are well known in the neighborhood in which he lives. The stables, once a model of neatness, have gradually assumed a meaner aspect, and the "attle, once su well-roumled, have berome rough, ill-kempt, and angular. The man's 'omdition is stmuper upon his features, is evident in his personal appearance, and ean be seen even in his driveway and door-yard. From the foregoing it therefore heennes plain that low results, concindent with prosperous times and the high ches which followes atversity, make an average which conforms neither to the one condition nor to the other.

TABLE 4.-Second class; individual resulls.

\begin{tabular}{|c|c|c|c|c|}
\hline No. 8. & No. 9. & No. 10. & No. 11. & No. 12. \\
\hline 16,600 & 36,750 & 390,000 & 72,600 & 33,300 \\
\hline 16,100 & 72,600 & 9,850 & 15,700 & 35,100 \\
\hline (i1, 800 & 7,800 & 7,600 & 19,937 & 23,000 \\
\hline 61,350 & 299,450 & 7,700 & 126,300 & 44,350 \\
\hline 19,600 & 16,200 & 81,700 & 107,500 & 400,000 \\
\hline 14,000 & 39,000 & 9,600 & 85,500 & 40,000 \\
\hline $1: 0,000$ & 10,700 & 8,800 & 83,200 & 12,400 \\
\hline 89,000 & 16,000 & 82,900 & 125,400 & 60,000 \\
\hline 50,400 & 20,500 & & 93,600 & 55,000 \\
\hline 45,300 & 13,500 & & 42,000 & 76,300 \\
\hline $41,0<0$ & 7,800 & & 43,300 & 81,200 \\
\hline 43,000 & 9,000 & & 16,900 & 12,900 \\
\hline & 30,100 & & 17,800 & 6,100 \\
\hline & $(39,0(x)$ & & $\cdots$ & $\ldots \ldots$ \\
\hline & 86,100 & & & \\
\hline 41,629 & $50,3 \geq 0$ & 62,269 & 65,633 & 69,973 \\
\hline
\end{tabular}

"Passing to the second class of dairies, it is seen from Table No. 4 that the averages extend from 41,629 to 69,973 . Those who have been engaged in dairy inspection, even to a small extent, know that dairy farmers as a class are poor in money but wonderfully rich in good intentions. There are many old stables which are kept very dean with shosel and hrom, and in which cattle are treaterl arcording to the golden rule. There are supplienl no sterilizer, nu improved cooler, no chert" floors, hut the farmer is always doing his best with the means at his disposal. II cools his milk by standing the can containing it in a tub of water; he washes his utensils as clean as possible with water and soap, and he keeps himself and his employees personally clean. Such cases are common, where a man tries to compen-

"Chert floor is a smooth cement floor. 
sate with muscle labor for that which he has not money to purchase. Such instances are represented in the second class. In the results there is little uniformity; oreasionally there is a low count which seems to be the result of a haply combination of good effort and good fortune. And so it is that there is lacking in the records of these dairies the uniformity which appeared so distinctively in Tabie No. 2. Favorable conditions come and go in the dairy business, just as in other vorations, and with no devies with which to overcome the numerous difliculties which arise before one who attemptr to produce an honest product, there can not he placed any great dependence upon the uniform excellence of the milk.

"A comparison between these dairies and dairy No. 5 is instructive. Structurally, the former are generally no poorer than the latter, yet if we look closely into the existing conditions we will find that in theme stables of the second class the whole atmosphere is inferior. The cattle look rougher and dirtier, accumulations of manure will more often collect upon the sides of the stables, the milk bottles, when ready for filling, shine less brightly, and the owners themselves appear not as tidy as the owner of No. 5. The matter of personal appearance in a dairyman is extremely significant in indicating the quality of that man's product. If the owners of the dairies here described should be arranged in a line accorling to their personal appearance the order of succession would very closely follow the bacterial order here given:

TABLe 5.-Third class; individual results.

\begin{tabular}{|c|c|c|c|c|}
\hline No. 13. & No. 14. & No. 15. & No. 16. & No. 17. \\
\hline 72,600 & 48,000 & Uneomntable. & 431,900 & 114,300 \\
\hline 59,400 & 299,000 & 80,000 & 275,500 & 19,550 \\
\hline 404,700 & 178,000 & 62,400 & 17,300 & 22,800 \\
\hline 455,000 & 583,000 & 120,800 & 12,500 & 156,000 \\
\hline 37,600 & 720,000 & 60,000 & Uncountable. & 53,000 \\
\hline 33,800 & 800,000 & Uncountable. & 19,900 & Uncountable. \\
\hline 25,300 & 120,000 & Uncountable. & 20,500 & Uneountable. \\
\hline 67,700 & 160,000 & 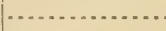 & 130,000 & \\
\hline & 22,000 & . & Uneountable. & \\
\hline & 25,600 & & 17,000 & \\
\hline & 31,500 & & & \\
\hline ( & 96,000 & & & \\
\hline 182,012 & 257,004 & & & \\
\hline
\end{tabular}

"The consideration of the third class of dairies introduces the discussion of the two factors which lie at the bottom of conditions in dairies totally bat. The first is dense ignorance and total unfitness of the man for the business; men who, perchance, have failed in every other eapacity by which they have been measured during life; men of foul habits and disgusting personality, whom we would not tolerate in the meanest capacity about our homes or in our places of business. Such are the men who take a part in the production of one of our most important food supplies. The serond factor responsible for hat results in a dairy is vicion:s indifference and sordid epposition to decency on the part of producers who are really intelligent and capable. With these it is considered meritorions to violate, as far an is lewally safe, the ordinance and wishes of the sanitary authorities. To such people the voice of an instrutor of hygienic dairying is aver the volos of a medhlesmeopprestor, and is to be met only by opposition.

"A good example of the results obtained by the totally igmonat dairyman may 
be seen in the record of No. 14. The owner of this dairy is good natured, stupid, and lazy, and is therefore a hard man to manage. He seems perfectly willing to lie down and be kicked at any time, and then, bearing you no ill will, and doubting not the wirdom of your procedure, he will go on just as before. The improvement that is noted in the latter part of his record is the result of extensive structural improvements in the stable. But as the effect of renovation gralually wore away, and the man relapsed into long-imbued habits, the record took a corresponding trend toward the old high average.

"In conclusion it may les satd, that the correspondence which exists hetween the result of the numerical determinations of hacteria and the conditions under which each supply is produced, are most striking when the dairies themselves are visited. Verbal descriptions and pictorial presentations are inarlecuate to complete in the mind the principle involved. These determinations, as well as the results of the physical and chemical test, have been published, each under the name of the dairyman in the annual reports of the Montclair board of health. They have brought the facts before the people in no uncertain manner, and the people have profited largely from it. Those who have appeared favorably in these reports have been blessed with increased trade, while on the other hand, many of the slovenly ones have found their business unprofitable. In addition to this, the improvements which have been made to the dairies, both in structure and in methods of procedure, are ton numerous to mention here. Laws and ordinances accomplish their part in bringing our milk supplies up to the point where they are respectable, lut it has been the experience of the writer that nothing is quite so effectual as fearles, truthful publicity.

"From the foregoing results, we are able to come to but one conclusion-i. e., that the number of bacteria per culde centincter in a given sample of milk forms an absolute indicator, by which the care and cleanliness to which the product has been subjected from the time it is drawn to its delivery into the hands of the analyst may be cletermined. In reply to the authoritative statements mentioned in the leginning, the writer can simply proint to these results and declare that if all this be coineidence, then coincidence must be predetermined."

\section{NEW MEXICO.}

Compiled laws of 1897 - sections $124+$ to 1257 refer to foods. No person shall knowingly sell a danaged or altered foud without the purchaser being fully informed.

\section{NEW YORK.}

Charles A. Wieting, commissioner of agriculture, Albany.

Laws of 1893 , chapter 338 (chap. 33 G. L.), article 1 , sections 1 to 12 , and article 2 , sections 20 to :5, amented, refer to milk. The state department of agriculture is charged with the execution of law relating to agricultural products. Samples must be taken in duplieate, ete. No person shall sell adulterated milk, meaning milk that is from eows within fifteen days hefore and five days after parturition, milk from animak fed on distillery waste or any putrefying substance, milk from cow in crowded or unhealthy condition, or nilk to which water or any foreign sulstance has been added. Preservatives are prohibiterl. Pure milk is defined as sweet and unalulterated; pure crean is that taken from such milk. The milk stamlari is 12 per cent solids, 3 per cent fat. Fxcept in New Tork and Kings comnties, skimmed milk is permitted when chean and wholesnme and sold for what it is, hut it can be sold only in the county where produced or an adjoining county. Milk cans, ete, holding market milk and rooms where it is stored must be kept elean and sanitary; but this provision does not apply to cities of the first class. No person shall wse the eans of 
another without the owner's consent, or remove therefrom or mar his name or mark. Condensed milk must he marle from pure and wholesome milk, a standard heing fixed, and all packages, shall be labeled with the name of the manufarturer, et.

Laws of 1901, volume 2, rhapter 429: Impure, unhealthy, arlulteraterl, etc., milk must not bes suplied to butter or cheese factories. Babock glassware userl in making milk tests for the basis of payment must first be examines and markesl hy the director of the New York agrienltural experiment station.

For the purpose of enforeing the laws and performing other work charged to it, the department of agrieulture has placerl an assistant commissioner in each we the 10 divisions into which the State has been divided, and among other duties these officials exeedute state laws relating to milk. They do not collect statisties relative to vity and town milk supply, hut so far as possible, they inspect milk sold in ritiess and town, and risit milk stations for the purpose of inspecting milk, ete., always going to such stations when requested to do so. Their visits are irregular. Milk is tested with lactometer, and, if suspicious, duplicate samples are taken for analysisone for the state and one for the owner. Inspectors visit farms suspected of heing in had orler. Bacteriological examinations are ocassionally made hy the analysts at the State agrieultural college.

In some of the large rities the department's agents inspect milk almost daily. In Albany the department has a wagon especially fitterl up with facilities for making quick tests, and it is out each rlay, sometimes going to neighloring towns. Tsually the milk in every can in the peddler's wagon is tested. In one summer month 740 cans were examined in Albany and only 3 suspected samples taken. Agents send detailed reports of work done to the department each week.

The number of prosecutions under the milk law in District I, inclueling 7 comntiess in the central atstern portion of the state in the year 1900, is shown hy the following:

\begin{tabular}{|c|c|c|}
\hline ...... 13 & Schenectady .......... 10 & Cohoes ... \\
\hline Albany ........... 15 & Mechanicsville........ & Stillwater .......... \\
\hline East Greenbush...... 3 & Round Lake......... . . & Ainsterdam... \\
\hline Milford .......... & Eagleville . . . . . . . . . & Richfield .... \\
\hline Beckmanstowr ...... & Pepacton ............. & Rensselaer. \\
\hline
\end{tabular}

New York. (Population, 3,4:37,202.)

[For comparison with other cities in Class I, see p. 2Х.]

Herman Betz, M. D., acting chief inspector, division of food inspection.

C. Golderman, secretary pro tem of the department of health.

The daily onsumption of milk, as computerl in the year 1901, was :33:3, 856 gallons, or an average of 0.78 pint per capita, bevides 4,000 gallons of cream. No skimmed milk was used. In reference to this apparently large consumption of milk, the following explanations are offererl: There is a floatin " population in New York ('ity of at least :300,000. Ahout 150,000 perwons living in outlying distriets spend the businexs hours in the dity; shoppers from neightoring towns and states number about 50,000 lere tay; there are many publie institutions where milk is nsed largely in the daily diet; prersons of some nationalities use mulh milk on aceount of its cheapmess; and a large amount is taken out of the eity by dining cars and vessels.

Milk is sold from about 12,000 stores and 4,000 wagons. About one-sixth of the supply comes to the aity in bottles which are tillew in creameries and bottling plants in the country, and which are generally shipped in boxes holding 12 quarts each. Probably as much more milk is bottled in the city. Perhaps 5 per cent of the total amount is pasteurized, and this treatment is increasing in favor. The retail price of milk is 6 cents per quart in summer and 8 cents in winter, producers receiving 21 to 
3 cents in summer and 3 to $3 \frac{3}{4}$ cents in winter." The milk from a few "model dairies" is sold throughout the year for 12 t, 15 cents per cuart. There are within the city limits 5,500 "herds," incluling 23,200 milch cows; 3,500 dairy farms send milk into the city. Eighty-five per cent or more of the total supply is received by rail over a dozen different lines, the longest shipment being 350 miles.

Section 59, and 63 to 67, incluwive, from the sanitary corde of laws, govern the sale of milk. In addition to these, regulations and rules have been arlopted. No milk shall be receiver or sold without a permit from the board of health. Permits must be conspicunusly pusted in stores and carried in wagons, which latter must show wagon number and permit number precerled hy the words "Department of health." Unwholesnme or arlulterated milk; "swill milk;" milk with any alderl foreign sul,stance; milk from animals kept for the most part in stables, or fed on distillery waste; and milk from diseased cows, from cows within fifteen days before or five days after calving, or from (ow kept in a (rowderl or unhealthy andition, is prohil)iterl, and may he seizerl and destroyerl. The milk standarl is 1'2 per cent solirds, 3 per cent fat. Skinmerl milk or milk from which any part of its cream has been removed is prohibited. Condensed milk must be made from pure milk, 25 per cent of the milk solisls must be fat, and no foreign substance except sugar can be ardiderl. Cream must be from pure milk amb contain no foreign substance. Milk must not be transferred from cans to other vesels on the streets, or ferries, or in degots, except when "transferred to vessel of purchaser at time of delivery." Vessels in which milk is kept must be covered so ats to "xclude dust and other impurities. Milk must not he kept for sale, nor bottled in a rom used for sleeping or domestic purposes, nor in al romm opening into the same. Before use, wilk bottles must bes washerl with a lontwater cleaning solution and then with hot water; they may be filled only at the dairy or creamery or in a room in the city properly protected to prevent contamination from dust. Eight rules published with the ordinanee and rexulations refer to certain miscellanems details, smeh as the storage of the milk, the construetion and care of the ice box, the use of ice in milk, etc. In a short circular intenderl to be sent to milk dealers whenever orasion ariven, the health degartment ralls sperial attention to a few important requirements of the law, principally in reference to aduiteration.

"The following statistics are taken from the Milk Reporter:

Total number of cans of milk, cream, and condensed milk received in the New York murket monthiy during 1902, and the average price of milk per quart each month.

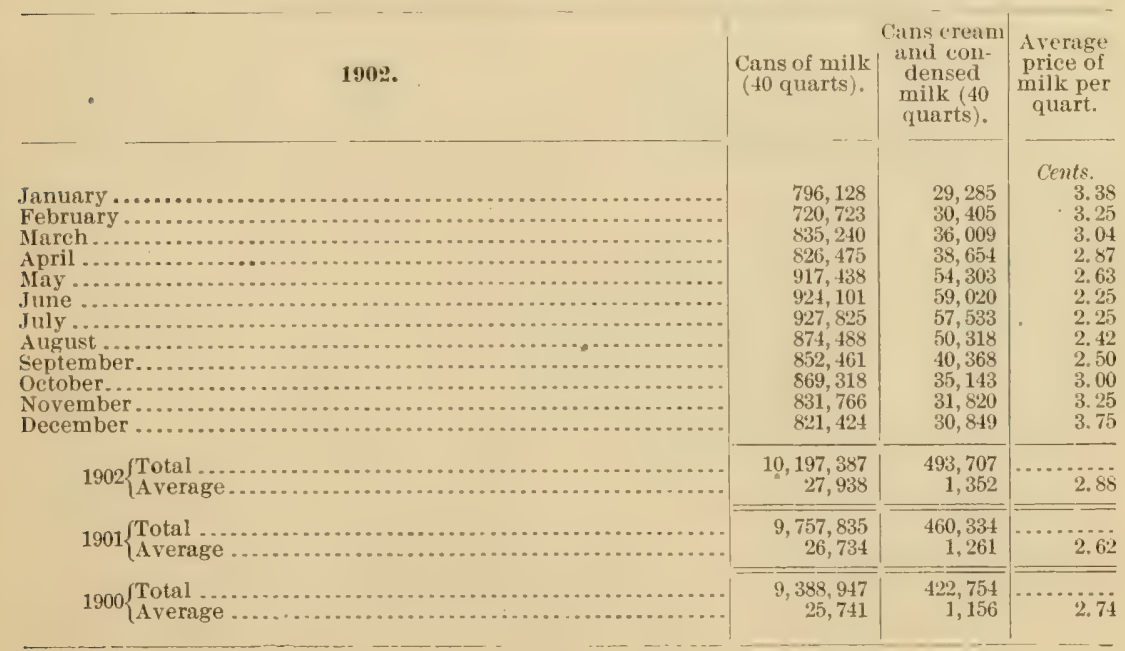


Rules and regulations governing the sale of milk are given in full in Appendix I (p. 165).

The amount expended annually in the supervision of the milk supply is included in the general appropriation to the rlepartment of health and can not be stated separately. Twelve officials-inspectors, chemists, and assistant cheinists-give their entire time to this work. During the last year of record 78,344 specimens of milk were examined; 1,313 samples were collected for analysis; 448 quarts of adulterated milk were destroyed; 560 of the 5,500 city dairy herds were inspected; 6,843 cows were examined; and 127 cows were condemned. Published reports for other recent years show much more work along these lines; for example, the report for 1899 (pp. 63 and 71) contains the following:

Milk inspections.

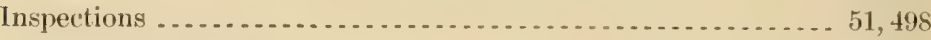

Specimens examined.... . . . . . . . . . . . . . . . . . . . . . 50,457

Samples of milk . . . . . . . . . . . . . . . . . . . . . . . . . . . . . 945

Citizens' complaints received.......................... 286

Original complaints by inspectors. ....................... 81

Citizens' complaints returned for orders . . . . . . . . . . . . . . . . 37

Citizens' complaints returned as negative................. 225

Citizens' complaints under observation .................... 2

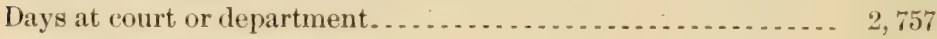

Special day inspections ............................ 10,310

Early morning inspections ............................ 335

Nights of special work ................................ 48

Quarts of adulterated milk destroyed ................... 95

Days in country or at laboratory ....................... 559

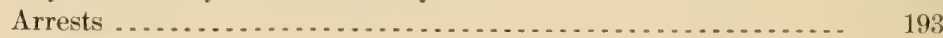

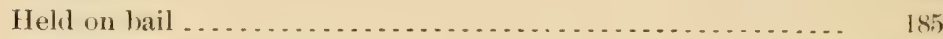

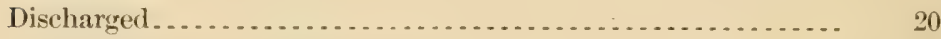

Trials at special or general sessions . . . . . . . . . . . . . . . . 180

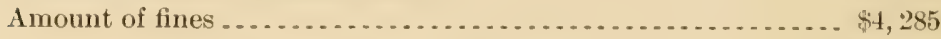

Inspection of cous.

Inspections of premises

Herds examined. . . . . . . . . . . . . . . . . . . . . . . . . . 461

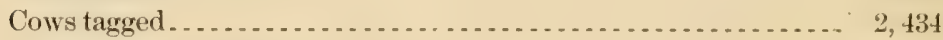

Temperatures taken .............................. 22, 421

Cows examined (tuberculin test) . . . . . . . . . . . . . . . . . 2, 580

Cows examined (tuberculin test), negative.............. 2,513

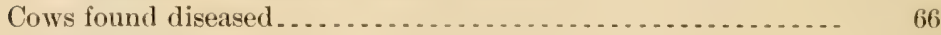

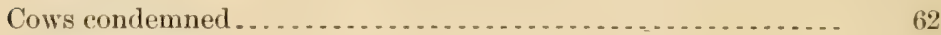

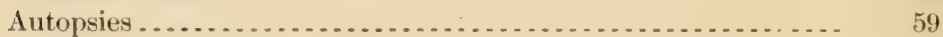

Citizens' complaints received.......................... 75

Citizens' complaints returned for orders.................. 5

'Citizens' complaints returned as negative.................. 68

Citizens' complaints under observation ................... 1

Original complaints by inspectors....................... 3

Days at court or department. . . . . . . . .

Nights special work. . . . . . . . . . . . . . $59 . \ldots \ldots \ldots$

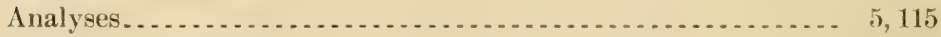

Experimental analyses............................... 764

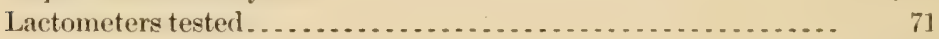

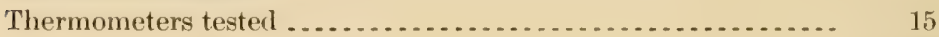

Days at court or department . . . . . . . . . . . . . . . . . 
The form for applieation to sell milk and the special-information form for milk sellers are shown in Appendix IV (p. 192).

The forms for milk-store permit and milk-wagon permit are shown in Appendix IV (p. 200).

The department of health has issued two instructive circulars regarding the production of pure nilk and the proper manner of handling it. Mention should be made alsen of the nilk commission of the medical society of the county of New York, which has undertaken to increase the supply and demand for high-grade milk. The work of this commission has alrearly shown very satisfactory results. It js referred to at length in an article entitled "Market milk: A plan for its improvement," which was publiwher in the Seventeenth Annual Report of the Bureau of Animal Industry.

The Rockefeller Institute for Medical Research early declared one of its purposes to be attention to matters of public: loggiene and a sturly was marle ly it, in 1901, of some of the questions relating to the milk supply of New York City. A partial report has heen publisher of the work accomplisher. Apecial attention was paid to the bacteria in the milk supply of the city, with reference to the number and charater of these germs at different times and the changes which occur hetween the milking of the cows and the delivery to consumers. An attempt was made to examine the conditions prevailing at producing farms, but the number visited was so manifestly inadeguate and the inspections nade were of such a character, judged from the report, that this branch of the investigation was merely suggestive in its result, and somewhat mislealing. Much more practical in plan, more efficient in execution, and more effective in result was a systematic investigation of the manner in which infants living in tenement houses in the city were ferl upon milk during the hot months. The reporters for the institute concluded that the most hopeful work in improving the milk supply of this city was being done through the milk (ommission alrealy mentioned and by the efforts of a few milk-supply companies and some enterprising individual dealers.

There has been recent decided improvement in the composition and cleanliness of the nilk supply. Nexiled proposed improvementy include regular inspections of farms and dairies, expecially at milking time; animals to be kept under more sanitary conditions; stables to be (leaner; milk to be shipped as soon as possible after milking.

\section{Buffalo. (Population, 352,387.)}

[For comparison with other cities in Class I, see p. 28.]

Edward Clark, M. D., and William B. May, M. D., milk inspectors.

The daily consumption of milk is estimated as 31,000 gallons, or 0.70 pint per capita. The daily consumption of skimmed milk is estimated as 10,000 gallons. Milk is sold from 1,200 stores and 529 wagons. About one-third of the supply is delivered in glass bottles, and these are filled in the city stores. A limited amount of pasteurized milk is used. It seems to be gaining in favor. The retail price of milk is 6 cents per (uart throughout the year, the producers receiving on the farm $2 \frac{1}{2}$ and 3 cents, respectively, in the summer and winter seasons. The product of a few dairies in the vicinity of the city which are conducted in an up-to-date manner is sold for 7 cents per yuart throughout the year. Within the city limits there are 22 heris of milch cows, including 340 head. Milk is sent into the city from 656 dairy farms.

The city ordinances relating to the supply and distribution of milk are quite lengthy. The sections on this subject, as published by the department of health in 1897, are Nos. 9, $87-97,100,237$, and 238 . A permit must be obtained from the department of health (fee, 1 ) for keeping cows within the city limits, but no person can keep more than 1 cow unless his "premises are in proportion of 1 acre of land 
to each and every cow ahove the number of 1." No jerson ('an 1)ring milk into the city for sale without a written permit from the health department (fee, \$:3); permit will not be issued until a satisfactory statement showing applicant's residence, number of cows, ete., has been filed. A license from the nayor is required for selling milk; the fee for each rehide is $\$ 2$. Licenses and permits must be renewed each May; they are revocalole for cause. Retail dealers, grocers, and hakers must display a sign showing from whom their milk is obtained. Milk wagons must show linense numbers, ete., and in summer months must be covered. The law prohibits the sale of impure or alulteraterl milk, including the product of diseawed (ows and "or)ws that for the most part are kept tied up in the stables," and cows ferl on garbage or other

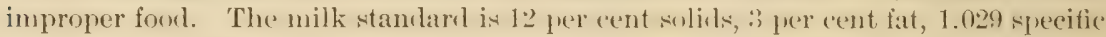
gravity. Skimmed milk may be sold if in a plainly marked vessel and does not contain a less percentage of casein and salts than is contained in whole milk. The construction of milk rooms and milk boxes must conform to preseribcd regulations. Milk cans nust the cleaned hefore being returned to the dairy. The removal of milk bottles from a house where at contagious disease exists and the filling of louttles on a delivery wagon are prohibited.

About $\$ 2,000$ is expended annually in the supervision of the milk supply. Two inspectors give all of their time to this work, and the city chemist a part of his time. During the last year 1,022 samples of milk were examined by lactometer; 6t by Babcock test and gravimetrie analysis; bateriologival examination was marle of :3 anples; and all of the herds within the city limits were twice inspected. A medical nilk commission has exercised considerable influenere towarl the inprovenent of the eity's milk supply hy giving special eneouragement to the interested in the production and sale of the highest grade of milk.

Among the recent improvements in the milk supply of the city the following is

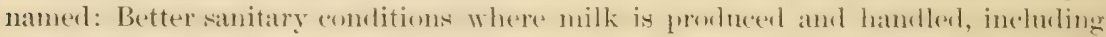
the practice of cleaning cans before they are retumed to the dairy farms. Needed improvements, as given, include thoromgh inswetion of all wairy farms semding milk into the city, the requirement that milk shall be cooled immediately after milking, refrigerator cars for shipment, and provison to protect milk from the heat when it is standing on the railroad platforms awaiting trains.

Rochester. (Population, 162,608.)

[For comparison with other eities in Class I, see p. 28.]

$\mathrm{V}^{*}$. O. Marshall, meat and milk inspector.

Estimated average amount of milk used daily, 17,000 gallons, or 0.83 pint per capita, besides some skimmed milk and cream. The milk is distributed from 75 stores and 275 wagons. There sems to be little interest manifesterl in pastenrization. The retail price of milk is 5 cents per quart in summer and 6 cents in winter, the producer receiving one-half these amount; skimmerl milk is sold for $2 \frac{1}{2}$ cents per quart. The milk of 10 well-conducted dairies in the vicinity is sold for 6 cent, per quart in summer and 8 cents in winter. Six herds, including 90 cows, are within the city limits, and milk is sent in from 200 dairy farms. Two-thirds of the total supply is shipped by rail, the farthest distance being 45 miles.

Ordinances Nos. 16, 17, and 18 (date?) refer to the milk supply. A license from the health department is required for the sale of milk, and its number must be shown wherever milk is sold. Its cost is $\$ 3$ per year, and it is revocable for cause. Special care is required in the selection of persons licensed. Aifulterated or monolesome milk, milk from cows diseased or "confinest for the most part" in stahlew, or fed on swill, brewery grains, distillery waste, or fermented food, or milk from cows fifteen days before or five days after calving, is forbidden. The milk standare is 12 per cent solide, 3 per cent fat. Skimmerl milk is allowed if plainly labelerl. Within 
the built-up portion of the city no one can keep more than 1 cow to a city lot 33 by 150 feet, and in the outlying portions of the city not more than 15 cuws for each acre of land, except by special permission of the health department. Stahles within the city must be kept clean, be well ventilated, and have 800 cubic feet of air space for each cow; the floor must be well drained; cows must be well herlderl and kept elean; and every cow must be allowed to go out doors at least two hours every day.

Ordinance section regulating the number of cows to los kept in the city is criven in Appendix I (p. 180).

The city expends amnually alout $8 t, 000$ for the supervision of the milk supply. Two officials-a milk inspector and chemist-give their entire time to this work. They examined cluring the past year 4,254 samples by lactometer and Babcock test; 204 samples hy gravimetric analysis; and 335 samples for bacterial content; and inspected all of the herds in the city, and 175 of the 200 dairy farms. The average butter-fat content of samples examinerl in 1900 was 3.91 per cent. In a study of the dirt content of milk as shown by the number of bacteria, it was found there were relatively fewer bacteria in summer than in the cold season, the relation heing $1: 3.5$. This is explained by the increased care necessarily given to milk in the warm weather to prevent its souring. In connection with some other work, the numbers oi bacteria per cubic centimeter in $2+$ samples of milk are given; four times they exceeded 5,000,000 and in four samples they were fewer than 100,000), the lowest number being 15,000

The most marked imporement recently male in the quality of the milk supply is due to inereased cleanliness in its production. It is recommencled that the use of swill feer be stopperl; that milk le mixed so that all cans from wne dairy will test alike; and that greater cleanliness be observed.

\section{Syracuse. (Population, 108,374.)}

[For comparison with other cities in Class I, see p. 28.]

F. E. Engelhardt, milk inspector and chemist.

The estimaterl average amount of milk used daily is $10,20()$ gallons, or 0.75 pint per (apita, lesicles 800 gallons of skimmerl milk and 250 gallons of cream. Milk is distributer from 340 stores and 195 wagoms. While the prictice of 11 ing glass bottles has greatly decreased during the past two years, there are yet ahout "2,500 in daily use, and these are filled on the farms and in one large milk-hamolling establishment in the ('ity. About 200 gallons of milk is pastenrized claily, ant its nee is inmeasing. The

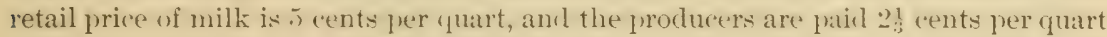
throughout the year. About 40 dairies are said to be conducted in a satisfactory manner. Only 1 of them, however, which guarantees its milk to contain 4.5 per cent of fat, receives more than the market price; its milk is sold for 8 cents. There are 14 dairy herds in the city, induling 176 cows; 217 dairies send milk into the city; only about 1 per cent is receiverl by railway, the lomgest shipment being 8 miles.

Articles VI and XVII, sections 4, 19, and 20, and the special milk laws of the sanitary code of the department of health, 1901, refer to milk. The milk inspeetor must, twice a year, visit all farms prolneing milk for sale in the city and insuect cans, water sulply, feeds, and the sanitary condition of stalles. License fee for the sale of milk is $\$ 10(?)$. Before license is granterl, persons sending milk to the city must file a certificate from a competent veterinarian, showing that his cows are free from disease. Impure or adulterated milk; milk from cows within five lays after (alving; milk from cows ferl on unwholesone food, or milk with any arled foreign substance, is prohibited. Persons working in a dairy shall not come in contact with persons having a contagious disease. Milk "ans on milk wagons, used in retailing skimmerl milk, sour milk, buttermilk, or "left" milk, shall he jainterl redhlish hown. Permit must be obtained for the sale of hottlerl milk. To bottles shall be filled with milk except

$$
25839-\text { No. } 46-03-9
$$


at a dairy, and all hottles must be properly sterilized before being again used. An ordinance has been passed requiring that all cows supplying the city with milk be submitted to the tuberculin test. The health officer, in a circulat letter dated November 12,1900 , requires special care in the production and handling of milk; cleanly practices which should be observed in dairies are described.

The anmual appropriation for the supervision of the city milk supply is $\$ 1,400$; $\$ 300$ of this is for laboratory expenses, and $\$ 1,100$ is for the salary of one officer-the milk inspector and chemist. During the vear 1902, 10,6:30 samples of milk were examined, all by lactometer, and doubtful cases by the Baberck test and gravimetric analysis, 120 analyses being made; 12 milk samples were found to be below the legal standard; $t$ cans of milk were condemmed and returned to the farms; 19 milk cans, 41 can covers, and 30 dippers were also conrlemmed. All the dairy heris and farms furnishing the city with milk were inspected during the year, and 1 was put under quarantine; 3,410 cows on 200 farms were examined for tuberculosis, use being made of the tuberculin test; 20 were found to be diseased. I recent anmal report of the milk inspector shows in detail the amount of work accomplished. It contains, also, much interesting information regarding the ways that milk becomes contaminated, and shows what methods should be followed to insure its purity. Such a report must be of much value in the hands of producers and dealers.

The milk association has done much to improve the supply and rlistribution of milk in this city. It has marle it possible for the milk depots to have on hand at all times properly pasteurizerl and unpasteurized milk and cream, skimmed nilk, huttermilk, cottage cheese, and fresh butter. These products are fresh and clean. Whenever outside perdlers are short of milk they are usually supplied by the association. The details of the work are conducted on hygienic principles.

Recent markerl improvements in the milk supply are due to better care of the stables and greater cleanliness in handling milk. The need of rigid restrittions against the use of adulterants and the much-arlvertised preservatives is emphasizerl. A competent person should oceasionally inspect the dairy farms and impart information as to the best methods of producing and handling milk.

\section{Albany. (Population, 94,151.)}

[For comparison with other cities in Class II, see p. 32.]

George L. Flanders, assistant State commissioner of agriculture.

The daily consumption of milk is estimated as $8,02.2$ gallons, or an average of 0.68 pint per capita, hesides 1,468 gallons of skimmerl milk and 213 gallons of eream. Milk is sold from 105 stores and 188 wagons. Only a small jart of the milk supply is delivered in glass bottles, and there are fillex in the city. (Ine firmi pasteurizes milk, but this practice is not gaining in favor. The retail price of milk is 6 cents per quart throughout the year, producers receiving :3 cents. There are no "model dairies" in the vicinity. Within the city limits there are 25 herds, including from 4 to 40 cows each, or a total of 366 cows, and milk is sent in from 150 dairy farms. One-fourth of the total supply is receiver by railway, the longest shipment heing 62 miles.

Rules and regulations adopted by the health dejartment in March, 1897, supplement the State laws regarding the city milk supply. License for the sale of milk is issued free of rharge. Cows must not be watered from wells in barnyards. Hand of milkers and milk utensils must be thoroughly cleaned. Milk shall not be handled by peroms exposed to or suffering from a contagions disease. Fottles must not be filled in the street, in ears, at railroad stations, or in any place where dust may get into the milk. Nor can milk be stored or bottled in living rooms, except. at the residence of customer.

The supervision of the city milk supply comes under State authority. During 
the past year 12,000 samples of milk were examined in the streets hy the lactometer, and occasional samples were examined by the Bahcock test and hy gravimetric analysis; a few bacteriological examinations were made; farms are inspected when there is special cause showing that this is necessary.

The establishment of a milk commission is under consideration by the county medical society. The object of such a commission would he the encouragement of the production of pure milk. A member of the committee of the medical society inquiring into this subject is quoted as saying: "This is being clone for our own protection, as we doctors are freciuently asked what milk dealers we would recomment, and, without data of our own, our recommendation can be little more than a suggestion. It is the design of this committee to ascertain who sells the best milk and have that used by the families where we are called. In this way we believe the public will soon find out where the best milk can he obtainerl, and there will then be a general demand for it." The committee will point out to dairymen what improvements can be made and encourage such improvements.

\section{Troy and Lansingburg. (Population, 73,246.)}

[For comparison with other cities in Class II, see p. 32.]

The daily consumption of milk is estimated as 6,000 gallons, or an average of 0.66 pint per capita, hesides 750 gallons of skimmerd milk. Milk is sold from nearly all of the small grocery stores and also from 120 wagons. About 15 per cent of the retail trade is supplied in glass bottles, filled in the city. Alont 12 per cent of the milk is pasteurized, and this treatment is increasing in favor. The retail price of milk is 6 cents per guart throughont the rear, the producer receiving 23 cents in summer and $3 \frac{1}{4}$ cents in winter. There are no "model dairies" near the city. Milk is received from 200 dairy farms, 12 per cent coming by railway, the longest shipment being 50 miles.

State authorities supervise the milk supply. The neet is felt of a closer examination of cows, farms, and water supply.

\section{Utica. (Population, 56,383.)}

[For comparison with other cities in class II, see p. 32.]

Wallace Clarke, health officer.

George C. Hodges, chemist, New Hartford.

The daily consumption of milk is estimated as 5,000 gallons, or an average of 0.71 pint per capita, besides 300 gallons of skimmed milk and 150 gallons of cream. Milk is sold from 60 stores and 210 wagons. About one-fourth of the total supply is delivered in glass bottles, which are filled at the producing farms. No milk is pasteurized. The retail price of milk is 5 cents per quart in summer and 6 cents in winter, producers receiving 2 and $2 \frac{1}{2}$ cents summer and winter, respectively. There are 2 or 3 especially well-conducted dairies near the city, but their milk is not sold for an extra price. There are 5 herds, including 50 cows, within the city limits, and milk i.s lorought to the eity in wagons, from 125 dairy farms, the longest haul being 10 miles.

Board of health regulations Nos. 18, 19, 20, and 50 refer to milk. Persons selling milk must register with the city clerk. Adulterated, etc., milk or cream is prohibited. Milk cans in delivery wagons must be protected from the sun. Bottles must be filled only at the dairy or place of general supply. The milk standard is 12 per cent solids, 3 per cent fat. Regulation No. 50, consisting of 21 rules for the conduct of dairies, is printed on a heavy cardboard and must be posted in the barn, dairy, and place of business of each person selling milk or cream. Persons exposed to or suffering from a contagious disease must not handle the milk supply. Rooms where 
milk is kept must be properly located. Skimmed milk must be in a can or receptacle painted a distinct blue color.

About $\$ 600$ is expended annually in the supervision of the milk supply, one inspector giving his entire time to this work. During the past year 50 samples of milk were examinerl by lactometer and Babcock test, suspected ones by gravimetric analysis; one bacteriological examination was marle; all the city herds and all the dairy farms were inspected.

\section{Yonkers. (Population, 47,931.)}

[For comparison with other eities in Class III, see p. 36.]

Clark A. Sloan, milk inspector.

The daily consumption of milk is estimated as 4,000 gallons, or 0.67 pint per eapita, hesides 40 gallons of eream. To skimmerl milk is sold. Milk is delivered from 208 stores and 56 wagons. About one-third of the milk retailed from wagons is delivered in glass lottles, fillerl mostly in the city. One firm pasteurized about 250 yuarts claily during June, July, August, and September. The retail price of milk is 5 to 7 cents per quart in summer and 6 to 7 cents in winter, producers receiving $2 \frac{1}{2}$ to 3 cents in summer and 3 to 4 cents in winter. The milk from 3 "model dairies" near the city is sold for 8 to 10 cents pere quart throughout the year. Within the city limits there are 28 herds, including 648 cows, and milk is sent in from $5 t$ dairy farms. About one-half of the milk is receivel hy raibay, the longest shipment being s.) miles.

Board of health regulations, seetions 48 to 61 , and an amendment frsised in April, 1900, refer to milk. Licenses for the sale of milk are granted free of charge. Adulterated, impure, etc., milk is prohibited. Brewers' grains may be fed if fresh. Bottled milk must not be lelivered where there is a contagious rlisease, and hottles must be washed before being refillexl. The milk standard is 12 fer cent solirds, 3 per cent fat. Skimmed milk must be labeled.

There is expended annually $\$ 2,500$ in the supervision of the milk supply. One inspector, chemint, and bacteriologist gives his entire time to this work, and a reterinary inspector part of his time. During the past year 123 milk samples were analyzer gravimetrically; t:3 were examined hateriologically for puss cells and bacterial content; all the city herds and 6 of the $5+$ dairy farms were inspected.

The form for prohibiting and permitting the use of bottles is shown in Appendix IV (p. 209).

There has been a marked improvement in the character of the milk supply, due to an increase in the amount of milk delivered in bottles, and better sanitary conditions at dairy premises. It is proposed that stores be compelled to handle only bottlerl milk.

\section{Binghamton. (Population, 39,647.)}

[For comparison with other cities in Class III, see 1. 36.]

Williain H. Abbott, secretary of the health department.

The daily consumption of milk is estimated as 2,520 gallons, or 0.51 pint per capita, besides 215 gallons of skimmed milk and 250 gallons of cream. Milk is sold from about 50 stores and 72 wagons. Fifty per cent of the milk is delivered in glass bottles, some filled at the farms and some in the city, and about 50 per cent is pasteurized, the practice incerasing. The retail price of milk is cents per puart throughout the year, the producers receiving 2 cents or less per quart in the summer season. The milk from a few specially well-conducted dairies is sold for 5 to 6 cents per quart. There are no dairy herds within the city limits. A small part of the milk from the dairy farms within a radius of 10 miles is brought to the city by trolley cars. 
Ordinances prohibit the sale of impure milk.

There is no milk inspector and nothing is expended by the city in the supervision of its milk supply. The bourd of health takes action when complaints are received. During the past year certain individuals made hacteriological examinations of 6 samples of milk.

\section{Elmira. (Population, 35,672.)}

[For comparison with other cities in Class III, see p. 36.]

Jacob Miller, city meat and milk inspector.

The daily consumption of milk is cstimated as 5,000 galloms, or 1.12 pints per capita. Milk is sold from 25 stores and 100 wagons. Glass bottles, some filled at the farms and some in the eity, are used largely in the delivery of milk. The retail price of milk is 5 cents per quart throughout the year, producers receiving 2 ? cents amd :3 cents in the two seasons. Four dairies are conducted in an especially satisfactory manner, but their milk is not sold for an advanced price. Within the city limits there are 8 herds, including 170 cows, and milk is sent in from 150 dairy farms within 6 miles of the city.

One official gives a part of his time to the supervision of the milk supply. During the past year all of the dairies sending milk into the city were inspected; a number of milk samples were examined by lactometer: none were examined hacteriologically.

It is stated that dairies should be kept in a more sanitary comelition, and more care should be taken as to the cleanliness of milk vessels.

A milk commission has recently been extablisberl for the purpose of encouraging the production and use of pure milk.

\section{Schenectady. (Population, 31,682.)}

[For comparison with other eities in Class III, see p. 36.]

William T. Clute, health officer.

The daily consumption of milk is estimated as 2,000 gallons, or 0.51 pint per capita. Milk is sold from 8 stores and $3 t$ wagons. A small portion is delivered in glass bottles, some filled in the city and some at the farms. No milk is pastenrizerl; this treatment was tried but discontinued. The retail price is 5 cents per quart in summer and 6 cents in winter, producers receiving $2 \frac{1}{2}$ and $: 3$ cents in the two seasons. There are no "model dairies" near the city. Within the city limits there are 3 herds, including 20 cows. About 260 gallons of milk is reecered daily by railway, the longest shipment being 18 miles.

Only a small amount is expendel by the city in the supervision of the milk supply. During the past year 500 samples of milk were examined by the lactometer; no bacteriological examinations were made; nome of the city herds or clairy farms were inspected.

There has been a recent improvement in the composition of the milk supply. The inspector recommends that the sanitary conditions of dairies be placed under the supervision of the board of health.

\section{Auburn. (Population, 30,345.)}

[For comparison with other cities in Class III, see p. 36.]

R. A. Dyer, acting milk inspector.

The daily consumption of mik is estimated as 3,000 gallons, or 0.79 pint per capita, besides 50 gallons of skimmed milk and 50 galions of cream. Milk is sold from 4 stores and 60 wagons, and about 10 per cent of it is delivered in glass bottles, which are filled at the farms. Sixty gallons of milk is pasteurized daily, and the milk thus 
treated is increasing in favor. The retail price is 5 cents per yuart throughout the year, the producers receiving $2 \frac{1}{2}$ cents. Within the city limits there are 5 herds, including 230 cows, and milk is sent in from 50 dairy farms, all within a radius of 6 miles.

('ity ordinances regulate the milk supply. The milk inspector must inspert all places where milk is produced or sold. Cow stables must be well constructerl, kept dean, and cows' must be given pure water. Adulterated, ete., milk and milk produced or handled where there is a contagious disease is prohibited.

I) ring the past year 4.50 samples of milk were examined for cream volume, and 160 by the Babork test; no bacteriological examinations were mate. In 1899, 421 eream tests were narle, showing an average of 17.5 per cent of crean by volume; 204 fat tests were made by the Babcock machine with an average of 4.2 per cent fat; 18 of the 50 dairy farms were visited.

The inspector suggests that the milk supply might be improved if dairy farms were inspereter under the direction of the state department of agrieulture, which has facilities for making bacteriological as well as chemical examinations of milk.

Watertown. (Population, 21,696.)

[For comparison with other eities in Class IV, see p. 40.]

Thomas Burns, veterinary surgeon.

The daily consumption of milk is extimated as 2,400 gallons, or 0.88 pint per capita, besides 750 gallons of skimmed milk and 150 gallons of cream. Milk is sold from 15 stores: and 40 wagons. Seven per cent of it is delivered in glass bottles, filled both in the city and at the farms. A small quantity is pasteurized, and the practice is increasing. The retail price of milk is 5 cents per quart throughout the year, producers receiving $2 \frac{1}{2}$ cents. Within the city there are " 14 herds, including 18 cows," and milk is brought in wagons from 37 dairy farms, the longest haul being 7 miles.

There is expended annually $\$ 750$ in the supervision of the milk supply, two officials giving a part of their time to this work. During the past year 850 samples were examined by lactometer, Babcock test, and gravimetric analysis. No bacteriological examinations were made. All the city herds and all the dairy farms were inspected. An effort is being made to induce all dairymen to adopt the tuberculin test.

Recent improvement in the supply is due to better dairy rations and better methods for the care and delivery of milk.

Mount Vernon. (Population, 21,228.)

[For comparison with other cities in Class IV, see p. 40.]

N. Eugene Smith, M. D., health officer.

The daily consumption of milk is estimated as 3,000 gallons, or 1.18 pints per capita, besides 350 gallons of cream. In explanation of the large consumption of milk, it is stated that large amounts are used in institutions the inmates of which are not numbered in the population of the city. No skimmed milk is sold. Milk is sold from 15 stores and 60 wagons. Nearly one-third of it is delivered in glass hottles, and these are filled at the receiving stations and by local dealers. A small amount is pastenrized, and this practice is increasing. The retail price is $7 \mathrm{to} 15$ cents per quart. in summer, and 8 to 15 cents in winter, producers receiving $1 \frac{1}{4}$ to 2 cents in summer and 3 cents in winter. The milk from 4 "model dairies" is sold for 8 to 15 cents per (puart throughout the year. Within the city linits there are 10 herds, including 100 cows, and milk is sent in from 90 dairy farms. One-third of the total supply is received by railway, the longest shipment being 75 miles.

The sanitary code of health, 1893 , sections 86 to 96 , refer to milk. License fee for the sale of milk is $\$ 1$. Aciulterated, ete., milk is frohibited. The milk standard is 
12 per cent solids, 3 per cent fat, and specific gravity not less than 1.02\%) ('ans and wagens from which skimmed milk is sold must he lalueled. Milk-elelivery wagons must be covered during the months of June, July, and August. Cows must not be ferl on garbage, swill, ete. Stores must post in a conspicuous place the names of perrons furnishing milk.

There is expented amnually 8500 in the supervision of the milk supply. J)uring the past year 40 samples of milk were examined by lactometer, Babcock test, and gravimetric analysis; 275 hacteriological examinations were marte for typhoid bacili, etc; all the city herds and all the dairy farms were inspected.

Rerently there has been an improvement in the quality of the milk suphly. Further inprovement would result if inspections were more frequent and if lisenses viere revoked wherever the milk is not being properly produced or handled.

\section{Lockport. (Population, 16,581.)}

[For comparison with other eities in Class IV, see p. 40.]

C. A. Warren, agent of the New York State department of agriculture.

The daily consumption of milk is estimated as 900 gallons, or an average of 0.43 pint per capita, besides 25 gallons of skimmed milk and 20) gallons of cream. Milk is sold from 30 stores and 24 wasons. Abont 10 per rent of it is lelivered in glass bottles filled both in the city and at the farms; none is pasteurized. The retail price is 5 cents per quart in summer and 6 cents in winter, producers receiving $2 \frac{1}{2}$ cents and 3 cents in the two seasons. There are no "molel dairies" near the city. Within the city limits there are 2 herds, including 14 cows, and milk is brought in wagons from 22 dairy farms, the longest haul being 6 miles.

An ordinance adopted January, 1887, refers to milk. License fee for the sale of milk is $\$ 1$ to $\$ 10$ for each person selling from wagons, the amount in each case to be fixed by the mayor, and $\$ 1$ for each person selling from a store or shop or peddling it in a small way.

The milk supply is under the supervision of State authorities, the city appropriating nothing for this work. During the past year about 1,000 samples of milk were examined by lactometer; 40 samples by the Babcock test; no bacteriological examinations were made; the aity herds and 12 of the 22 dairy farms were inspected.

Rome. (Population, 15,343.)

[For comparison with other cities in Class IV, see p. 40.]

J. M. Currie, V. S., meat and milk inspector.

The daily consumption of milk is estimated as 1,000 yallons, or 0.52 pint per capita. Milk is sold from 4 stores and 26 wagons. About one-fourth of it is delivered in glass bottles, filled usually at the farms; nome is pastentizerl. The retail price is 4 cents per quart in summer and 5 cents in winter, producers receiving 2 cents and $2 \frac{1}{2}$ cents in the two seasons. There are no "model dairies" near the city. Within the eity limits there are 3 herds, including 65 (owws, and milk is sent in from 36 dairy farms within a radius of 6 miles.

The meat and milk inspector (salary $\$ 800$ ) gives almout one-half of his time to the supervision of the milk supply. During the past year 106 samples were examinerl by lactometer and Babcock test. All the city herds and dairy farms were inspected.

Recent improvement is due to cleaner barns, better cattle fords, and more sanitary methods of milking. It is recommended that milk dealers be required to obtain licenses, and that coupon tickets employed in making regular retail sales he destroyed after being used once. 


\section{NORTH CAROLINA.}

Public laws of 1899, (hapter 86, refers to foods. It is unlawful to sell adulterated food, which is defined at length. The board of agriculture shall examine samples of fool and may publish results. Solicitor shall prosecute for violations reported by the commissioner of agriculture.

\section{NORTH DAKOTA.}

E. E. Kaufman, assistant dairy and food commissioner, Fargo.

Laws of 1899 , chapter 72 , refers to milk. The enforcement of this law is charged to the aswistant state dairy and food crmmissioner. Persons selling from vehicles milk from more than 4 cows in any city or town of 1,000 or more inhabitants must obtain license from the assistant commissioner. License fore is sl annually, and all licenses expire in June. ('ertain information must he furnished, and changes of employees must he reporterl. Vehicles shall be narked with license number and name and place of business of owner. License is necessary also for selling milk from a store or stand; fee $\$ 1$. It is unlawful to sell milk that is adulterated, unwholesome, etc; milk from an aninal diseared or havine ulcers, ete.; milk from a cow within fifteen days hefore and five days atter larturition; nilk from cows kept in an unhealthy manner, or erean from any such milk. Fkimmed milk shall be sold only for what it is. The milk standard is 12 per cent solids, 3 per cent fat; the cream standard is 15 per cent fat.

In the year 1900 the assistant dairy commisioner iscued 3i) licenses for the sale of milk in s cities and town. Funds not being available, no systenatic inspection was made, and as no complaints were reeeived no samples of milk were taken for examination. The dairies supplying milk to three or four cities were inspected. In cities where licenses have been taken out, it is estinated that 650 cows supply milk to 1,950 private families, 40 hotels, 30 restaurants and lunch counters, 30 boarding houses, and 20 soda fomtains; the average amount of milk reyuired per month is 25,000 gallons, cream 50 gallons, and skimmed milk 1,900 gallons.

The form for report upon inspection of dairies and herds is shown in Appendix IV (p. 196).

\section{OHIO.}

Joseph E. Blackburn, State dairy and food commissioner, Columbus.

Ohio Laws of 1859 , volume 86 , page 229; and 1886 , volume 83 , page 120 , amencled, and page 178 , sections !) to 13 , refer to milk, ete. The einforcement of laws relating to foods and drink: is charged to the State dairy and food commiswioner. It is unlawful to sell milk to which water or any foreign substance has been added, or milk from diseased cows. The milk standard is 12 per cent solids, 3 per cent fat, except in May and June, when it is 113 per cent solisk. Skimmed milk may be cold from cans plainly labeled. Cows producing market milk shall not be kept in a cramped or unhealthy comlition or fed upon foud that will produce unwholerome milk. Condensed milk shall he mate from pure unskimmerl milk, and be plainly labeled, etc.

Ohio Laws of 1884 -volume 81 , jage 67 , anended, refers to foods. It forbids the sale of any food that is adulterated, which term is defined at length.

The annual report of the dairy and food commissoner shows that during the past year 22 samples of milk were examined under his direction; 11 of these were from Canton and the remainder from 8 other towns. Only 3 of the samples contained more than 12 per cent total solids, most of them being badly adulterated. 


\section{Cleveland. (Population, 381,768.)}

[For comparison with other eities in Class I, see p. 28.]

Charles H. Stone, jr., inspector of food.

The average daily consmption of milk is estimated as 21, 490 gallons, or 0.45 jint pere capita, besides 1,000 gallons of skimmed milk and 500 gallons of eream. Milk is sold from 1,200 stores and 580 wagons. About one-third the total supply is delivered in glass bottles, and these are filled in the city. Very little milk is pasteurized, but there seems to be a growing deinand for it. The retail price of milk is 5 cents per quart in summer and 6 cents in winter. There are 2 well-onducted dairies near the city which sell their product for 6 cents per quart in summer and 7 cents in the winter. Within the city limits there are 31 dairy herds, including 225 cows. Milk is sent in from 650 dairy farms, the longest shipment being 65 miles.

There is no references to a milk ordinance in the special report of the ford inspector upon the city milk supply.

The city expends in the supervision of its forl supply about 83,000 annually, one food inspector, two assistants, and one sanitary uflicer giving their entire time to this work. It is impossible to state what portion of the expenditure is in the interest of the milk supply. During the year 6,666 samples of milk were examined by the Babcock test; 300 samples for pathogenic bacteria; and all the city milch cows and 250 of the 650 dairy farms were inspected.

Recent improvements are due to better stabling facilities ior mileh cows and to more careful hanlling of the milk. A better knowledge of the care of milk is needed alike by the producer, peddler, and consumer.

\section{Cincinnati. (Population, 325,902.)}

[Hor comparison with other cities in Class I, see p. 28.]

\section{J. Stewart Hagen, M. D., milk inspector.}

The daily consumption of milk is estimated as 25,000 gallons, or 0.61 pint per capita. It is said that about half of the milk supply of the eity is controlled by one large concern. Milk is sold from about 200 stcres and 200 wagrons. (ilass jars are used only by 3 or 4 milk dealers; they are filled in the city. Milk is pasteurized by two or three concerns and the practice is increasing. The retail price of milk throughout the year is 6 cents per quart, producers being paid half as much. The product of 3 especially well-conducted dairies near the city is sold for 8 cents per guart. Within the city limits there are about 40 dairy herds, including 1,400 head. About 200 dairy farms send milk into the city. Appoximately 25 per cent of the milk supply is shipped by railway, the most distant point of supply being 100 miles away.

Ni) milk ordinance for (incinnati haw been reen, but the milk inspector reports the milk standard to be 12 per cent solids, 3.1 per cent fat.

The annual expenditure for the supervision of the city milk supply is about $\$ 1,200$. One officer, as dairy and milk inspector, devotes his entire time to the duties of the office. During the year 600 samples were examined by the Babcock test; no bacteriological examinations were marle; all the herds in the city and 150 of the 200 dairy farms were inspected.

The milk supply has recently shown a little improvement on acconnt of the increase of the portion that is produced in the country. There should be a rigid inspection for milk containing preservatives, and dairies within the city should be moved to districts where pasturage is available. 
Toledo. (Population, 131,822.)

[For comparison with other cities in Class I, see p. 28.]

William H. Schurtz, meat and milk inspector.

The daily consumption of milk is estimated as 9,650 gallons, or 0.59 pint per capita. Milk is sold from 221 stores and 253 wagons. Glass bottles are used in the delivery of milk, some of them being filler in the country and others in the city. The practice of pasteurizing milk is new and is increasing rapidly. The retail price of milk is 5 cents per quart in smmer and 6 cents in winter, and the producer on the farm realizes 3 cents per quart in summer and 4 cents in winter. There is 1 so(alled "model dairy" in this locality, whose product sells at 8 cents per cuart in summer and 10 cents in winter. Within the city there are 41 dairy herds, including 769 cows, and milk is sent into the city from 202 dairy farms. About one-third of the total milk supply is received by railway, the longest shipment being 80 miles.

An ordinance of 26 sections, passed in November, 1900, regulates the sale of milk and cream. A permit to sell milk or cream must be obtained from the board of police commissioners. One dollar must be paid for each conveyance, and each must show permit number and name of dealer. Permits expire the first of the year and are revocable for cause. When application for one is made, certain information regarding the source of the milk supply, wagons to be used in delivery, etc., must. be filed. Pernit will not be issued until authorities are satisfied, after inspection, with the sanitary conditions of the producing dairien, but while the matter is being considered the applicant may carry on his business. The milk inspector must examine for tubereulosis and other diseases all eows supplying milk for city trade which are in Lucas County, those outside of the county to be examined by some local persons acceptable to the board of health. The tuberculin test may be used. All animals shall be tagged to show results of their examination. Dairy premises must be kept reasonably clean. Names of dairymen supplying milk must be posted in stores. The milk standard is 12 per cent solids, 3 per cent fat, except in May and June, when it is $11 \frac{1}{2}$ per cent solids. Skimmed milk may be sold if in vessels plainly labeled and from delivery wagons properly marked. The use of preservatives is prohibited. Filthy milk, milk or cream from diseased cows or cows fed on slops, milk produced in a place where a contagious disease exists, or handled by a person recently so exposed, is prohibited, and may be confiscated if offered for sale.

About $\$ 1,250$ is expended annually in the supervision of the city milk supply, and one inspector gives his entire time to this work. During the year 450 samples of milk were examined by gravimetric analysis; there were 43 prosecutions and 42 convictions of persons selling milk and cream adulterated by preservatives and otherwise; 14 bacteriological examinations were made of milk from cows having tuberculosis, actinomyensis, and (ow pox; all of the herds within the city and 131 of the 202 dairy farms sending milk into the city were inspected. In the preceding year 106 dairies were inspected and 293 of the 2,914 (ows were found to be unfit for producing milk.

There has recently been a decrease in the sale of adulterated, skimmed, or preserved milk. Government inspectors should have supervision of dairies producing market milk.

The applieation for permit to sell milk, upon the back of which the milk ordinance is printed, ealls for the following information: Name of applicant and residence; location of dairy or dairies from which applicant obtains his milk and name of owner of such dairy or dairies; number of cows in dairy from which applicant obtains his milk; manner of disposing of milk. 
Columbus. (Population, 125,560.)

[For comparison with other eities in Class I, see p. 28.]

W. D. Deuschle, M. D., superintendent of the division of health.

The daily consumption of milk is estimated as 6,397 gallons, or 0.41 pint per capita. The amounts of skimmed milk and cream are not known. Milk is sold from 134 stores and 286 wagons. (ilass bottles filled at the producing fams are used quite extensively in the delivery of milk. The practice of pasteurizing is just bexinning and is growing in favor. The retail price of milk is 6 cents and the wholesale teents per quart throughout the year. There are several dairies near the city conducted on a better plan than others, but their milk is not sold at an extra price. There are only a few milch cows kept within the city limits, the greater part of the milk supply coming from 191 dairy farms. Only a small portion of the milk supply is shipped into the city by rail, the longest shipment being 40 miles.

Sections 109, 114-118, 120 (amended), and 133 of ordinance No. 6169 refer to the milk supply. A permit to sell milk must be obtained from the board of health. It is issued free and on egndition that only pure milk will be handled. Permit number and location of dairy must be shown on wagons, and names of dairymen supplying milk must be posted in stores. The sale of adulterated milk-milk from diseased cows or cows fed upon swill, etc.-is prohibited. The milk standard is 12 per cent solicls, 3 per cent fat, except in May and June, when it is 11 per cent solids, 2.5 per cent fat. Milk below the standard, including skimmed milk, may be sold if plainly marked. Cows in the city must be kept in buildings having goud floors, and from April to September they must not be confined any other time than from $6 \mathbf{~ p}$. $\mathbf{m}$. to 6 a. m. City cow stables must be thoroughly cleaned daily from April to October, and twice a week from November to March, and stables yards must be kept clean.

About $\$ 1,200$ is expended annually in the supervision of the milk supply. One milk inspector and one bacteriologist give their entire time to this work. During the past year 456 samples of milk were examined by lactometer and the Babcock test, and a fer examinations were made for typhoid and tubercle bacilli. No inspection of the few herds in the city or of the dairy farms is reported. (Seventy-eight herds were inspected the year previous.)

Recent marked improvements have been shown in the purity and quality of the milk. Suggested improvements include the inspection by a competent veterinarian of all herds for tuberculosis, the licensing of all milk dealers, the more frequent sanitary inspection of dairies, and more chemical and bacteriological examinations of milk.

\section{Dayton. (Population, 85,333.)}

[For comparison with other cities in Class II, see p. 32.]

Nelson Emmons, sr., clerk of the board of health.

The daily consumption of milk is estimated as 6,500 gallons, or an average of 0.61 pint per capita, besides 200 gallons of skimmed milk and 150 gallons of cream. Milk is sold from about 300 stores and 100 wagons. A large amount of the milk supply is delivered in glass bottles which are filled at the farms. Little or no milk is pasteurized. The retail price is 5 to 6 cents per quart throughout the year, the producers receiving $3_{4}^{3}$ cents. The milk from 3 especially well-conducted dairies near the city is sold for 7 cents per quart. There are 194 milch cows, in 15 heris, within the city limits. Fifty dairy farms send in milk; about one-half is received by railway (steam and electric), the longest shipment being 20 miles.

The city has no milk ordinance.

No appropriation is marle by the city for the supervision of its milk supply. The sanitary police and meat inspector has given a part of his time to the work. During 
the past year 5 milk samples were examined for preservatives; all the eity herds and 37 of the 50 dairy farms were inspected.

It is proposed that the city shonld have a veterinary surgeon as a dairy inspector, and an ordinance requiring milk dealers to be licensed.

\section{Youngstown. (Population, 44,885.)}

[For comparison with other cities in Class III, see p. 36.]

\section{A. Banks, food inspector.}

Estimated daily consumption of milk is 2,000 gallons, or 0.36 pint per capita. Milk is sold from 45 stores and 60 wagons. Two-thirds of it is delivered in glass bottles filled at the produring farms. I small quantity of milk is pasteurized; this practice is increasing. Milk is retailed at 6 cents per fuart in summer and 8 cents in winter, producers receiving 3 and 4 cents in the two seasons. There are a few spe(ially well-conlucted dairies near the city, but they do not receive an extra price for their milk. There are no dairy herds within the city limits. Forty dairy farms send in milk. Only a small portion is received by railway, the longest shipment being 15 miles.

About $\$ 100$ is expended ammally in the supervision of the milk supply, the food inspector giving a fart of his time to this work. During the past year 109 samples of milk were examined hy the centrifugal method; 12 hacteriological examinations were made; no farms were inspected. It is said that formaldehyde is used extensively during the hot weather to prevent souring.

A needed improvement is the licensing of all milk dealers.

Akron. (Population, 42,728.)

[For comparison with other cities in Class III, see p. 36.]

II. W. Hoye, milk inspector.

The daily consumption of milk is estimated as 3,000 gallons, or 0.56 pint per capita, besides 100 gallons of eream. Milk is sold from 75 stores and 88 wagons. One-sixth of the total supuly is delivered in grlass bottles, most of which are fillerl at the farms. No milk is pasteurized. Milk is retailed at 5 cents jer quart in summer and is cents in winter. There are no "model dairies" near the city. Within the city limits there are 2 herds, including 25 cows, and milk is sent in from 60 dairy farms. Four hundred gallons of milk is received by railway daily, the longest shipment heing 20 miles.

There is expended annually $\$ 300 \mathrm{in}$ the supervision of the milk supply, one official giving a part of his time to this work. During the past year 580 samples were examined by lactometer and lactoscope; no bateriological examinations were male; the city herds and 54 of the 60 dairy farms were inspected.

Springfield. (P'opulation, 38,253.)

[For comparison with other cities in Class III, see 1 . 36.]

Henry H. Seys, M. D., health officer.

This city has no milk ordinance, and there is no inspection of the milk supply. Milk is sold for 5 to 6 cents per quart throughout the year. Two dairies, better conducter than others, receive 6 cents jeer guart for their product. The longest distance milk is sent to the city is 8 miles.

\section{Canton. (Population, 30,667.)}

[For comparison with other cities in Class III, see p. 36.]

James Sell, milk inspector.

The daily consmption of milk is estinated an 2,000 gallons, or 0.52 pint per capita. Milk is sold from 70 wagons. About 10 per cent of the milk is delivered in glass 
bottles, filled mostly at the farms. One firm pasteurizes milk, and the practice is increasing very slowly. The retail price of milk is 5 cents per quart throughout the year, producers receiving 3 cents. Within the city limits there are 3 herds, including 41 cows, and milk is sent in from dairy farms within a radius of 10 miles.

State laws supplemented by hoard of health rules govern the sale of milk. Persons selling milk must have a permit.

There is expended antually 8700 by the city in the supervision of its milk supply, two officials - a food and dairy inspector and a milk inspector-giving a part of their time to this work. During the past year milk samples were examined by the lactometer. The city herds and all the dairy farms were inspected.

Hamilton. (Population, 23,914.)

[For comparison with other cities in Class IV, see p. 42.]

A. L. Smedley, M. D, health officer.

The daily consumption of milk is estimated as 1,027 gallons, or 0.34 pint per capita. nilk is sold from to stores and 32 wagons. About 3.5 per cent is delivered in glases bottles, half of these being filled at the farms, the rest in the city. About 5 per cent of the total supply is pastenrized; the practice is not increasing. The retail price is 6 cents per quart throughout the year. There are no "model dairies" near the city. Within the city there are 21 herds, including 73 cows, and milk is brought in wagons from 26 dairy farms, the longest haul being 6 miles.

The health department, with an appropriation of $\$ 1,500$ for all its work, has supervision over the milk supply. During the past year 162 samples of milk were examined by the lactometer and Babork test, and by chemical tests for preservatives; two examinations were mate for tuhercle hacilli; $1: 3$ (ity herds and 16 of the 26 dairy farms were inspected.

Recent improvement in the milk supply is due to the decreased use of preservatives. It is recommenderl that the sale of milk in butcher shops be prohibiterl; that milk in grocery stores be kent in separate refrigerating hoxes; and that no cows be kept within the city limits.

Warren. (Population, 8,529.)

[For comparison with other cities in Class IV, see pp. 42.]

Thomas B. Webb, sanitary policeman and food inspector.

The daily (onsumption of milk is e-timaterl as 64.5 gallons, or 0.60 pint per capita, besides 20 gallons of skimmed milk and 20 gallons of cream. Milk is sold from 1 store and 11 wagons. About 30 per cent of the milk is delivered in glass bottles, half of these being filled in the city and the rest at the farms; none is pasteurized. The retail price is 5 cents per quart throughout the year, producers receiving $2 \frac{1}{2}$ to 3 cents in summer and 3 cents in winter. The milk from 5 dairies, conducted in a better manner than others, is sold at the regular price. Within the city limits there is 1 herd ( 24 cows), and milk is received from 16 dairy farms. In summer about 3 per cent is shipped by railway, the longest shipment being 15 miles.

Secs. Nos. 66 to 72 of the sanitary code of January, 1896, refer to milk. Milk licene fes is 50 cents, but persons having only 1 cow are exempt. Impure, arlulterated, etc., milk is prohibiterl. Skimmed milk must he labeled. Milk must be from cows inspected and found to be bealthy.

Fothing is appropriated by the city for the supervision of its milk supply. The dairies pay for the inspection. During the past year 123 muples of milk were examined by the Babcock test; 2 :amples were tested for preservatives; no bacteriolngical examinations were made; the city herd and the dairy farms were inspected.

Recent improvement is due to better food and water supply of dairies, ventilation, and cleanliness of stables, the semiannul inspection of dairies, and the publication in the daily papers of the monthly fat tests. 
Fostoria. (Population, 7,730.)

[For comparison with other cities in Class IV, see p. 42.]

E. A. Schubert, milk inspector.

The daily consumption of milk is estimated as 400 gallons, or 0.41 pint per capita, besides 25 gallons of skimmerl milk and 10 gallons of (ream. Milk is wold from 10 stores and 8 wagons. $A$ small portion of it is delivered in glass bottles, and these are filled at the farms. Some milk is pasteurized, and the practice is increasing. The retail price is 5 cents per quart in summer and 6 cents in winter, prorlucers receiving 3 and $3 \frac{1}{2}$ cents in the two seasons. The milk from 2 well-conducted dairies is sold for 6 cents in summer and 7 cents in winter. Within the city limits there is "1 herd, including 125 cows," and milk is hrought in wagons from 6 dairy farms, the longest haul being 3 miles.

There is expended annually $\$ 200$ in the supervision of the milk supply, one official giving a part of his time to this work. During the past year 108 samples were examined by lactometer, Bahcock test, and gravimetric analysis; 3 bacteriological examinations were marle; all the eity cows and all the dairy farms were inspected.

Recent improvement in the milk supply is due to better feed and to the introduction of a better grade of cattle.

\section{OKLAHOMA.}

Compiler statutes of 1893 , (hapter 25 , article 36 , seetion 16 , and article 50 , sections 1,2 , and 8 , and chapter 8 , section 4, refer to milk, foods, ete. The board of health shall destroy any impure article of food oifered for sale. Milk from a "cow not in proper condition of health," or any milk adulterated by water or a deleterious substance, or colored, shall not be sold or delivered. The adulteration of food or drink with framblent intent is a mistemeanor. The buyer shall be informed if provisions are diseased or unwholesome.

\section{OREGON.}

J. W. Bailey, State dairy and food commissioner, Portland.

An act approved February 27, 1901, refers to milk, foods, etc., and its enforcement is charged to the State dairy and food commiswioner. The chemist of the State agricultural college shall aweist hy making analyses. Justices' courts have concurrent jurisliction. The dairy and food commiswioner shall inspert dairy herds, methods of feeding, ete, as often as pussible. The dairy and food commissioner shall keep a list of all persons selling milk or cream in cities of 10,000 or more inhabitants. Such perons shall secure from the ('ommiswioner a metal plate giving name, ete., for attachment to each wagon, and shall report changes of management or location. The State veterinarian shal! be notified of diseased cows. Owners must give proper attention to dairies found in a filthy or unhealthy condition, when so directed by the commis. sioner. Milch cows in stables shall be allowerl 800 culic feet of air space each; when facing each other, shall not be closer than 10 feet. Stables shall be well rentilated and kept in a healthful condition. It is unlawful to sell any unclean, diseased, or unwholesome food or drink. The sale of milk from cows within fifteen days before and five days after parturition, or from eows fed on unwholesome food, is forbiden. The use of certain preservatives in milk or cream is prohibited. No adulterated food or drink shall besold unleses plainly marked to show its true character. Such articles are defined in detail, and include milk having less than 12 per cent solids or 3 per

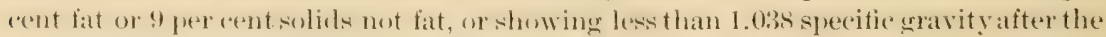
removal of the cream. Manure must not he allowed to acoumulate within 150 feet of any barn where dairy cows are stabled. 


\section{Portland. (Population, 90,426.)}

[For comparison with other cities in Class II, see p. 32.]

\section{J. W. Bailey, State dairy and food commissioner.}

Th: daily consumption of milk is estimated as 7,500 gallons, or an average of 0.66 pint per capita. Milk is sold from 25 stores and 150 wagons. Only a very small portion of the milk supply is delivered in hottles, and these are filled in the eity. Little or no milk is pasteurized. The retail price is 5 cents per quart in summer and 5 to $7 \frac{1}{2}$ cents in winter, producers receiving $2 \frac{1}{2}$ cents in summer and $2 \frac{1}{2}$ to 3 cents in winter. There are no "model dairies" near the city. Within the city limits there are 45 herds, including 240 cows, and milk is brought in wagons from dairy farms within a radius of 8 miles.

The eity has no milk ordinance, the milk supply being regulated by State laws.

The city makes no appropriation for the supervision of its milk supply. The little work accomplished along this line is done by the State dairy and foor commission. During the past year 75 milk samples were examined by the Babcock test and by gravimetric analysis; no bacteriological examinations were made; 20 of the 45 city herds and 15 dairy farms were inspected.

The commissioner believes that the daily press, by arouning an interest in the subject, might bring about a much needed improvement in the milk supply.

\section{PENNSYLVANIA.}

John Hamilton, secretary of agriculture, Harrisburg.

Session of 1895 , No. 258; 1893, No. 96; 1885, No. 186; 1878, No. 183; and 1869, No. 56 , refer to milk, etc. The dairy and food commissioner $1 \mathrm{~s}$ charged with the enforcement of laws concerning dairy products. The councils of cities and boroughs are anthorizert to provide for milk inspection. Persons pedtling milk in cities or villages of over 1,000 inhahitants must have the vehicle markesl with name of owner and locality where milk is produced. To person shall knowingly sell adulterated or unwholesome milk. The addition of ice $t o$ milk is declared an adulteration, and milk from animals fed on distillery waste, ete., is declarerl to be impure. The sale, in cities of the second and third classes, of milk to which water or any other foreign substance has heen added, or milk from diseased (ows (or groats) or cows fed on any putrefying substance is forbidden. In such cities the milk stantard is 12.5 per cent solids, 3 per cent fat, specifie gravity at $60^{\circ}$ F. between 1.029 and 1.033 ; and skimmed milk may be sold if plainly marked, its standard being 6 per cent cream by volume, 2.5 per cent fat, specific gravity at $60^{\circ} \mathrm{F}$. between 1.032 and $1.03 \pi$. It is the duty of bureaus of health in cities of the second and third classes to register all dairies and milk depots and to require owners' names to be placesl upon vehicles delivering milk, and to prevent the sale of adulterated milk.

Session of 1895 , No. 233 , refers to fonds. It forbids the sale of food that is adulterated, which term is defined at length.

Although the supervision of the milk supply of cities is largely under local hoards of health, some work along this line has been aceomplished by the State department of agriculture.

A bacteriological examination of the milk supply of several cities was made in 1897 and reported upon in the annual report of the department. A recent report of the dairy and food commissioner shows that in 6 months 287 samples of milk from 18 cities and towns and 4 samples of cream from "2 eities were examined. One hundred and ninety-seven of the milk samples and 3 of the cream samples were foumd to be of gool composition; 25 milk samples were skinmed, :32 wateresl, 4:2 preserved, and 3 colored. In the majority of cases the milk samples were taken from perldlers or milk depots. 


\section{Philadelphia. (Population, 1,293,697.)}

[For comparison with other eities in Class I, see p. 28.]

William J. Byrnes, chief inspector of milk.

It is extimater that 75,000 gallons of milk are used daily, or an average of 0.46 pint per capita. Little skimmed milk is used. Milk is sold in about 1,500 stores and served from about 2,000 wagons. A large number of glass jars are used in the retail trade, most of them being filled in the city. Only a small part of the mills is pasteurizerl. The retail price of milk in the summer and winter is 6 and 8 cents per quart, respectively. Farmers are paid for their milk, $a$ delivered in the city, $2 \frac{1}{2}$ to 3 cents per quart $b$ in the summer period, and $3 \frac{1}{2}$ to 4 cents in the winter. The two periods vary in length in lifferent years; for instance, in 1901 the summer period extended over only three months. A few first-class dairies are in the vicinity of Philadelphia and their milk lorings an extra price. Abont 500 her's, including 5,000 cows, are within the city linits. Milk is sent into the city from alout 2,500 dairy farms; almost all of it comes by rail, the most distant point of supply being 200 miles away. A large portion of the milk supply is received from the adjoining States-New York, New Jersey, Maryland, and Delaware.

The few State laws which apply to the nilk supply of Philadelphia are supplemented by an ordinance of 10 sections, approver Septemlex 2:3, 1890. This prohibits the sale of adulterated or impure milk, including the procluct of animals kept in a crowled or unhealthy condition, or fed on distillery waste usually called "swill," or any substance in a state of putrefaction or of an unwholesome nature; and milk which has been exposerl to the emanations of a person sick with a contagious disease, and milk from tuherculous cow. The milk standard is 12 ver cent milk solids and 8.5 per cent solids not fat. Skimmert milk may he sold if its container is plainly labeled. It must contain at least 8.5 per cent of milk solids, exclusive of fat. (By a supreme court decision, there is no legal distinction between partially and wholly or separator-skimmed milk.) The director of the department of public safety is required to appoint an inspector of milk and the necessary assistants, analyste, clerks, and collectors of samples for the enforcement of this orlinance through the board of health. The officers are given authority to examine suspecterl milk wherever found, and, if their test shows it to be adulterated, 'to pour it out or return it to the consignor. Samples must be taken in duplicate. The inspector shall each month publish, in such city newspapers as are willing to give space, a full list of all whose milk was testerl the previons month and the results of the analyes, with notes, to show the extent of deficiency of samples below standard.

The last section of the ordinance states that no person shall he liable for violation

"The monthly prices, from 1899 to 1901, received by shippers per quart for milk delivered in the city, treight prepaid, as annomeed by the Philadelphia Milk Exchange and reported by The Milk Reporter, are as follows:

\begin{tabular}{|c|c|c|c|c|c|c|c|}
\hline Month. & 1899. & 1900. & 1901. & Month. & 1899. & 1900. & 1901. \\
\hline 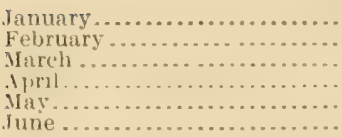 & \begin{tabular}{l|l}
$3 \frac{1}{2}$ \\
$3 \frac{1}{2}$ \\
$3 \frac{1}{2}$ \\
33 \\
$3 \frac{1}{2}$ \\
$2 \frac{1}{2}$ \\
$2 \frac{1}{2}$
\end{tabular} & \begin{tabular}{l|l}
4 \\
$3 \frac{1}{2}$ \\
$3 \frac{1}{2}$ \\
31 \\
$3 \frac{1}{2}$ \\
$3 \frac{1}{2}$ \\
$3 \frac{1}{2}$
\end{tabular} & $\begin{array}{l}3 \frac{1}{2} \\
3 \frac{1}{2} \\
3 \frac{1}{2} \\
3: 1 \\
3 \frac{1}{2} \\
3\end{array}$ & 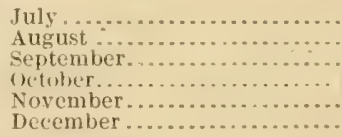 & $\begin{array}{l}3 \\
3 \\
3 \frac{1}{2} \\
31 \\
4 \\
4 \\
4\end{array}$ & $\begin{array}{l}3 \frac{1}{2} \\
3 \frac{1}{2} \\
3 \frac{1}{2} \\
3 \frac{2}{2} \\
4 \\
4\end{array}$ & \\
\hline
\end{tabular}

$b$ In wholesale transactions the "dry" quart is used. 
if he shows to the satisfaction of the magistrate or court that he could not have ascertained that the milk was impure, etc.

The amount expended by the eity in the supervision of the milk supply the past year was $\$ 9,580$. Ten officials, including a chief milk inspector, assistant inspectors, and collectors of samples, give their entire time to this work. During the year $47,0 \% 2$ samples were tested by the lactometer, and 95 samples were analyzed to obtain evidence for prosecutions. The lactometer samples represented 1,684,768 quarts, of which 21,384 , or 1.25 per cent, were condemned for adulteration with Water, 267 for being skimmed, 480 for containing formaldehyde, and 4 for containing coloring matter (annatto). Practically half of the condemnations were upon the railroad receiving platforms, and in such cases, the shippers being beyond the jurisdiction of the inspector, the condemned milk was reshipped with a certificate of condemnation, and the dealer accustomed to handle the product of the dairy was warned not to receive later shipments unless free from adulteration. The percentages of milk examined that was condemned in each month of the year were as follows:

\begin{tabular}{|c|c|c|}
\hline January .... . . . . . . 1.73 & May.. & September......... \\
\hline 1.03 & .1 .82 & October ......... \\
\hline & 1.88 & nber. \\
\hline & August & December ..... \\
\hline
\end{tabular}

It is claimed, on the basis of many analyes, that the entire city milk supply will average over 13 per cent total solids and over \pm per c'ent fat. During the year 390 samples were examined for pus cells, pathogenic germs, etc:; these included numerous samples of milk obtained from houses where there were typhoid fever cases, which were examined with negative results. During the year all the dairies within the city limits were inspected; nothing is known of the conditions obtaining on many of the supplying farms which are beyond the city limits. Thesucessful work of the milk commission of the Pediatric society is described in the article "Aarket Milk: A plan for its improvement." $\iota$

The forms for recording data regarding preliminary inspections of milk are shown in Appendix IV (p. 205).

The form for notice of condemnation of milk and stub for same are shown in Appendix IV (p. 207).

The milk supply has improved in quality, records showing that the percentage found adulterated has fallen from 11.15 in 1892 to abunt 1.50 in 1900 . Suggesterl improvements include legislation proviling for a higher standard for milk and for periodical, thorough, veterinary and santary inspection of dairy cattle and dairy farms, and the awarding of certificates where conditions are found to hes satisfictory. It is believed that the most practical way to provide for the inspection of dairies, especially those in other states, is to require each clairyman to secure a jermit before commeneing to sell milk in the city, the permit to be based upon the conditions at his dairy and to be revocable.

\section{Pittsburg. (Population, 321,616.)}

[For comparison with other cities un Class I, see p. 28.]

Albert H. Edwards, meat and milk inspector.

Estimated average amount of milk used dauly is 30,000 gallons (including the milk and cream used in the Ice-cream business), or 0.75 pint per capita. Milk is distributed from 1,230 stores and 425 warons About 1,000 gallons is pasterursed; this treatment, however, does not seem to be gainng in lavor. Inly a small part of the milk is delivered in bottles, and they are filled in the city. The retail proe ot muk

"Serenteenth Anmual Report of Bureau of Anmual Industry, pl). 158-193;,

$25839-$ No. $46-03-10$ 
is 6 to 8 cents per quart in summer and 8 to 10 cents in winter, producers on the farm being paid 3 cents and $33_{4}^{3}$ cents in the two seasons. There are 3 or 4 "model dairies" near the eity, the milk from which is sold at 10 cents jer quart throughout the year. There are 241 dairy herds within the city limits. About 90 per cent of the milk supply is receiver by railway, the longest shipment being 50 miles.

The city publishes State laws referring to market milk.

In the supervision of its milk supply the city expends amnually about $\$ 3,000$. one official, an assistant milk inspector, gives his entire time to the work, and another a part of his tine. During the year 4,997 samples of milk were examined by Babeock test and gravimetric analysis; no bacteriological examinations were made.

The most marked recent improvement has been in facilities for caring for milk. sugrested improvements include thorough inspection of all dairy farms and eattle, sterilizing or thorough scalding of all milk vessels, and examination of eattle for tuberculosis twice a year.

Allegheny. (Population, 129,896.)

[For comparison with other eities in Class I, see 1). 28.]

John Lippert, meat and milk inspector.

It is etimated that 5,000 gallons of milk are nserl daily, an average of 0.31 pint per (apita. Milk is distributed from 160 stores and 400 wagons. The few bottles nsed in its delivery are filled in the eity. A eonsideralle portion of the milk supply is pasteurized, and the use of such is increasing. The retail price of milk is 6 eents per yuart in summer and 8 cents in winter; the producers on the farm receive 3 and 43 cents per quart in the two seasons. Within the city limits there are 38 heris, including 500 cows. Milk is sent into the eity from 90 dairy farms; alwut two-thirds comes by railway, and the longest shipment is 150 miles.

The city has no milk ordinance; the State laws alone regulate the milk supply.

There is expended annually $\$ 2,700$ in the supervision of the city milk supply. ()ne inspector and one bacteriologist give all or a large part of their time to this work. Ahout 2,000 sumples were examined for lat content and 180 for tuberele and typhoid bacilli, and all of the dairies in the city were inspected during the past year.

The enactment of milk ordinances is strongly recommended.

Scranton. (P'opulation, 102,026.)

[For comparison with other cities in Class I, see p. 28.]

Fred. J. Widmayer, food and milk inspector.

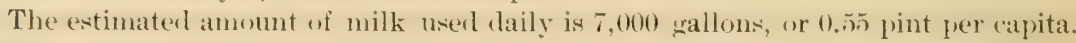
Milk is distributed from 170 stores and 125 wagons, and about 75 per cent of it is delivered in glass jars. A number of the large concerns, handling perhaps half of the jars, do their bottling at milk-receiving stations in the country. Little, if any, pasteurized milk is used. The retail price of milk is 6 cents per quart in summer and 7 cents in winter, proluers receiving $1_{4}^{3}$ cents in summer and $2_{-5}^{7}$ ("ents in winter. No dairy near the vity is conducterl in what might be ealled an entirely satisfactory manner. There are only two herds within the eity limits; they include 25 cows. Milk is sent into the eity from abont 400 dairy farms, the most distant being 30 miles.

The nilk supply is regulated by State laws applying to dities of the second and thirc classes, and by a few sections enacted several years ago by the city board of health. The latter provide as follows: The sale of adulteraterl milk, milk with any foreign substance added, or milk "from cows fed upon brewery grains or other deleterious substances," is prohibited. "Wholesale and retail dealers are recpuired to procure licenses annually from the batrd of health and display same prominently. 
All milk eans must be numbered, and cans containing skimmed milk must be plainly labeler. Delivery wagons shall show the name of owner and number of license.

About $\$ 1,200$ per year is expended hy the city in the supervision of its milk supply. One food and milk inspector gives his entire time to this work. In the past year 2,612 samples of milk were examined by the lactometer and the Baberek test; no baeteriological examinations were marle. None of the dairies, either within or outside the city, have been inspected.

There has recently been a decrease in the practice of adulterating milk by the addition of water. Needed improvements as given include the extencion of the inspector's authority to dairies heyond the city limits, frequent inspection of those dairies, and regulations as to the use of ensilage and brewers' grains.

\section{Reading. (Population, 78,961.)}

[For comparison with other cities in Class II, see p. 32.]

Peter Texter, market commissioner.

The daily consumption of milk is estimated as 4,200 gallons, or an arerage of 0.43 pint per capita, besides 1,400 gallons of skimmed milk and 175 gallons of cream. Milk is sold from about 20 stores and 145 wagons. A very small anount of milk is delivered in glass bottles, and these are filled at the farms. One-seventh of the milk is pasteurized, and the practice is gaining in faror. The consumers pay 6 cents and the producers receive :3 cents per quart for milk throughout the year. There are no herrls within the city limits. Milk is brought to the eity in wagons from 1 th dairy farms, the longest haul being 8 miles.

The eity prints State laws regulating the milk supply.

There is expended annually 8185 in the supervision of the milk supply. The market commissioner gives a part of his time to this work. During the past year 121 samples of milk were examined by the lactometer; no hacteriological examinations were made.

\section{Erie. (Population, 52,733.)}

[For comparison with other eities in Class II, see p. 32.]

J. K. Hallock, secretary of the board of health.

The daily eonsumption of milk is estimated as 3,600 gallons, or an average of 0.54 pint per capita, besides 250 gallons of skimmesl milk and 150 gallons of cream. Milk is sold from 123 stores and 78 wagons. A very linited amount of milk is delivered in glass bottles which are filled at the producing farms and in the eity. Very little milk is pasteurized, and the pratice is not increasing. The retail price of milk is 5 cents per yuart throughout the year, producers receiving $2 ! 3$ and 233 'ents in summer and winter, respectively. There are no "model dairies" near the city. Within the city there are 3 herds, including 25 cows. Wagons bring in milk from 100 dairy farms, the longest haul being 15 miles.

Rules and regulations (17 sections) of the hoard of health refer to the eity milk supply. Permits for the sale of milk or cream are issued free of charge. Adulterated, etc., milk is prohibiterl. Cows supplying milk must be examined hy a veterinarian (not necessarily with the tuberculin test) within one year. ('ow stahles must be clean and, like milk rooms, must be properly located and constructed. From June to September milk and cream vehicles must be ecpuiplesl with ice boxes. Milk bottles, etc., must be properly cleaned after use, and must not be taken from at yuarantined house without the permission of the boarl of health. Persons exposed to or suffering from contagions disase must not handle milk or crean for sale. The food inspector must inspect, at least once a month, all stores and wagons from which milk is sold and take samples therefrom for analysis.

For the full text of the rules and regulations of the boatril of health conerening the? milk supply, see Appendix I (p. 17t). 
During the past year 1,758 samples of milk were examined hy the Babock test, and by gravimetric analysis, the lactometer being used in a fuw instances. No hacteriological examinations were made. All the city herds and all the dairy farms were inspected. The large number of samples examined shows that the law recpuiring the inspection of each dealer's milk once a month is well observed.

The form used for application for milk license is shown in Appendix IV (p. 189). The form for report upon inspection of dairies is shown in Appendix IV (p. 196).

\section{Wilkesbarre. (Population, 51,721.)}

[For comparison with other cities in Class II, see p. 32.]

Walter Davis, M. D., water and milk inspector.

The daily eonsumption of milk is estimated as "2, syo gallons, or an average of 0.45 pint per capita. This is sold from about 40 stores and 60 wagons. Only one dealer supplies milk in grass hottles, and these are filled some in the city and some in the country. A very small quantity of milk is pasteurized; and the practice is not increasing. The retail price of milk is 6 cents per quart in summer and 8 cents in winter, producers receiving $2 \frac{1}{2}$ cents and $3 \frac{1}{2}$ cents in the two seasons. A few dairies are conducted in a very satisfactory manner, but receive no advance in price for their product. There are no city herds. Fifty-three dairy farms near the city furnish. about one-half of the total supply; the balance is received by railway, the longest shipment being 130 miles.

An ordinance adopted in October, 1896, supplements the State laws in regard to the milk supply. Persons selling milk must register with the water and milk inspector and report to him the location of dairy farms.

The water and milk inspector (salary, $\$ 300$ ) gives a part of his time to the supervision of the milk supply. During the jast year 350 -amples of milk were examined by the lactometer, and suspected samples hy the labcock test; and the 53 nearby dairy farms were inspected. On 15 farms conditions were found to be satisfactory, on 21 fairly satisfactory, and on the remainder unsatisfactory.

A milk laboratory and a dairy inspector are much needed.

\section{Harrisburg. (Population, 50,167.)}

[For comparison with other cities in Class II, see p. 32.]

The daily consumption of milk is estimated as 2,500 gallons, or an average of 0.40

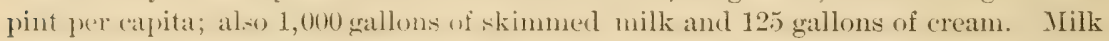
is sold from 12 stores and 75 wagons. About 5 per cent of the total supply is delivered in grass bottles, and these are filled in the city. No milk is pasteurized. The retail price is 5 to 6 cents per quart in summer and 6 cents in winter, producers receiving :3 rents and 4 cents in the two seasons. The milk from one especially well-eonducted dairy is sold for 7 cents per quart throughout the year. Within the city limits there are 2 dairy herds, including 20 head, and milk is sent in from 90 dairy farms. Only about 8 per cent of the milk supply is received by railway, the longest shipment being 15 miles.

The city exercises practically no supervision over its milk supply.

It has been suggested that the best way to improve the quality of the milk is to bring to the attention of the public the advantages of pure milk and encourage those who produce it; and that flagrant violations of the milk laws should be promptly prosecuted.

\section{Lancaster. (Population, $41,459$.}

[For comparison with other c1ties in Class III, see p. 38.]

II. W. Raub, secretary and physician of the board of health.

The estimated daily consumption of milk is 1 , solo gallons, or 0.35 pint per apita, besides 50 gallens of cream. Milk is sold from 12, stores, 96 wagons; and 50 private 
houses. Three-fourths of the milk is delivered in glass bottles, half of these being filled on the farms and the rest in the city. Ahout 150 gallons of nilk is pasteurized daily, which practice is increasing very slowly. The retail price of milk is 5 to 6 cents per quart throughout the year, jroducers receiving $2 ! 3$ to 3 cents. About 10 dairies are conducted in a satisfactory manner, their milk being sold at the rexglar price. Within the city limits there are 58 milch cows, kept in 28 stables, and milk is sent in from 145 dairy farms. (Only 58 gallons of milk is received daily by railway, the longest shipment being 14 miles.

State laws, supplemented by eity ordinances, govern the milk suphly. The milk inspector is authorized to destroy all impure and adulterated milk. License fee for the sale of milk is $\$ 1$, and $\$ 1$ for each wagon after the first.

During the past year only $\$ \$$ was expended by the city in the supervision of its milk supply: 505 milk samples were examined 'sy the lactometer and Babcock test; all the eity herils and 80 of the 145 dairy farms were inspected. The secrets ry of the hoard of health in 1895 made a thorough inspection of all the dairies producing milk for use in the city.

His annual report gives an interesting aceount of the conclitions moler which the milk supply is produced, and includes the following statement:

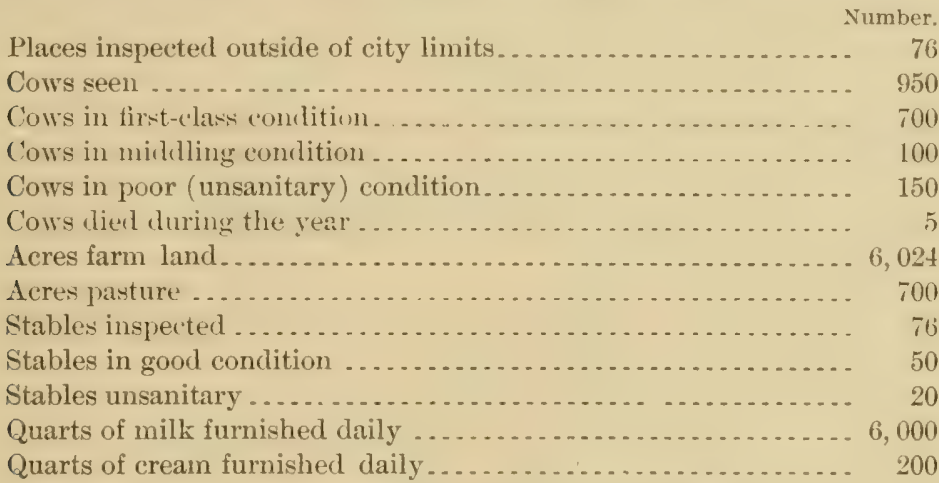

Food used. Corn, chop, bran, ship stuff, malt, and pasture:

Places using malt with other food ................... 22

Places using malt alone ............................ 2

Places using pasturage alone........................ 2

Total milk houses inspected............................. 68

Total milk houses, sanitary and best condition .............. 55

Total milk houses, good (ventilation wanting) ............... 13

Cans and vessels for milking and storing almost all neat, clean, and well cared for.

Recent improvement has been shown in the cleanliness of stables and care in handling milk. A law regulating the samitary condition of dairies is said to be much needed.

Altoona. (Population, 38,973.)

[For comparison with other cities in Class III, see p. 36.]

J. D. Miller, health officer.

Estimated daily consumption of milk is 3,500 gallons, or 0.72 pint per capita. Milk is sold from 25 stores and 40 wagons. Four dairies deliver milk in slass bottles, and the are filled both in the city and at the farms. Little or no milk is pasteurized. The retail price of milk is 6 cents per quart in summer and 7 cents in winter, producers receiving 4 and 5 cents in the two seasons. Within the city limits there are 2 herds, including 20 cows. About 50 per cent of the milk is receiverl by railway, the longest shipment being 15 miles. 
Nothing is expenterl by the city in the supervision of its milk supply. During the past year 36 samples of milk were analyzed hy the State chemist, and no bacteriological examinations were made.

A recent improvement in the quality of the milk is due to a decrease in the use of formaldehyde.

\section{Johnstown. (Population, 35,936.)}

No reply to inquiries was received.

\section{Allentown. (Population, 35,416.)}

[For comparison with other cities in Class III, see p. 36.]

Morris F. Cawley, health officer.

Milk retails at 6 cents per quart throughout the year.

The (ity does practically no inspection work, and no record of the milk supply is kept. During the past year 40 milk samples were examined hy Marchand's test.

\section{McKeesport. (Population, 34,227.)}

[For comparison with other eities in Class III, see p. 38.]

A. C. Wallace, secretary of the board of health.

The estimated daily consumption of milk is 2,000 gallons, or 0.47 pint per capita. Milk is sold from a number of stores and 50 wagons. Within the city limits there are 15 herds, including $30 \mathrm{cows}$, and about 12 dairy farms send milk into the city, the longest distance being 5 miles.

During the past year no inspection work has been done.

\section{Chester. (Population, 33,988.)}

[For comparison with other cities in Class III, see p. 38.]

IV. G. Monroe, secretary of the board of health.

The daily consumption of milk is estimated as 1,625 gallons, or 0.38 pint per capita, besides 600 galloms of skimmed milk. Milk is sold from 28 stores and 59 wagons. Retail price of milk is 6 cents per quart in summer and 8 cents in winter, producers receiving 3 and 4 (ents, respectively. Milk is supplied from 70 dairy farms. One hmolred gallons is received by railway daily, the longest shipment heing 10 miles.

The eity has no milk inspector.

York. (Population, 33,708.)

[For comparison with other cities in Class III, see p. 38.]

Francis X. Weil, M. D., health officer.

Estimated daily consumption of milk is 1,350 gallons, or 0.32 pint per capita, hesides 150 gallons of skimmert milk and 25 gallons of eream. Milk is sold from almut 25 stores and to wagons. Three-fourths of the milk supply is delivered in glass hottles filled in the city. Pasteurized milk is delivered by only 1 wagon, and its wese is not increasing. Nilk is retailed at 5 cents per quart throughout the year, producers being paid 3 cents. There are no "model dairies" near the city, and no dairy herds within the city limite. Milk is sent in from 28 dairy farms, all within 8 miles of the city; none is received by railway.

The city has an ordinance forbidling the sale of adulteraterl milk, but exereises no supervision over its milk supply. 


\section{Williamsport. (P'opulation, 28,757.)}

[For comparison with other cities in Class III, see 1). 38.]

C. W. Youngman, M.D., health ofticer.

Estimated daily consumption of milk is 875 gallons, or 0.24 jint per capita. Mlilk is sold from 14 stores and 90 wagons. Ahout ome-half is delivered in glasy bottles filled at the farms. No milk is pasteurized. Retail price of milk is 5 cents per quart in summer and 6 cents in winter, producers receiving 21 and 3 cents, respectively. The milk from 3 well-conducted dairies near the city is sold at the regular price. Within the eity limits there are 4 herds, incluling 25 enw, and milk is sent in from 127 dairy farms. About one-seventh is received by railway, the longest shipment being 50 miles.

The health officer (salary $\$ 1,000$ ) gives a part of his time to the supervision of the (ity milk supply. During the past year 73 milk samples were examined by lactometer and crean gauge; no hacteriological examinations were marle; all the eity herds and all the dairy farms were inspecterl. A report of the conditions obtaining at the dairy farms is published annually in the daily papers by the hoard of health. The dairies are divicled into three classes: The first includes those having everything necessary for the production of good milk, the second those less well eupiphed, and the third includes dairies having the poorest equipment.

\section{Newcastle. (Population, 28,339.)}

[For comparison with other eities in Class III, see p. 38.]

W. H. Vance, health officer.

The estimated daily consumption of milk is 700 gallons, or 0.20 pint per capita, besides 150 gallons of skimmerl milk and 150 gallons of cream. Milk is sold from about 75 stores and 75 wagons, and is retailed at 6 ('ents per quart in summer and 7 cents in winter. There are no dairy herly within the eity limits. Milk is sent in from 75 dairy farms, all within a radius of 7 miles of the city.

The city has no milk ordinanee and exercises no supervision over its milk supply.

Easton. (Population, 25,238.)

No reply to inquiries was received.

Lebanon. (Population, 17,628.)

[For comparison with other cities in Class IV, see p. 42.]

W. L. Brunner, secretary of the board of health.

The daily consumption of milk is estimated as 1,500 gallons, or an arerage of 0.68 pint per (apita, hesides 200 gallons of skimmed milk and 300 gallons of cream. Milk is sold from 45 wagons, a large anount being delivered in glass bottles filled both at the farms and in the city. No milk is pasteurized. The retail price is 6 cents per quart throughout the year, producers receiving 2 cents and 3 cents in the two seasons. There are no "model dairies" near the eity. Within the city limits there are 15 herds, including about 60 cows, and milk is brought in wagons from 60 dairy farms, the longest hanl being 8 miles.

The city has no milk ordinance.

About $\$ 100$ is expended annually in the supervision of the milk supply. During the past year 70 samples of milk were examined by the Babcock test, no bacteriological examinations were made; 12 of the 15 city herds, but none of the dairy farms, were inspected. 


\section{Meadville. (Population, 10.291.)}

[For comparison with other cities in Class IV, see p. 42.]

\section{Courtney MeLean, V. S., milk inspector.}

The daily consumption of milk is estimated as 875 gallons, or 0.68 pint per capita. Milk is sold from 2 stores and 30 wagons. Perhaps one-fifth of it is delivered in glass bottles, most of these being filled at the farms; none is pasteurized. The retail price is 6 cents per quart throughout the year, producers receiving 3 cents. There are no "model dairieg" near the city. Milk is brought in wagon from 30 dairy farms ( 489 cows), the longest haul being 4 miles.

There is no herd within the city.

Board of health rules Nos. 9, 36, 50, and 56-66 refer to milk. Any person wishing to sell milk must apply for an inspertion of his cattle, anpointments, ete, and agree to observe certain regulations. The milk inspector must, previous to the issuing of permits, and annually, inspect all dairies, cows, and appointments for supplying milk for sale in the city. Milk from diseased cows, adulterated milk, etc., is prohibited. The milk standard is 12.5 per cent solids, 3.5 per cent fat, specific gravity between 1.029 and 1.03:3. Milk exposed to infection hy contagions disease shall not be sold.

There is expended ammally $\$ 200$ in the supervision of the milk supply, one official giving a part of his time to this work. During the past year 976 samples were examined by lactometer and Baberck test; no hacteriological exaninations were made; all the dairy farms were insperted. The milk inspector has published, in a little pramphlet, the milk regulations, together with fractical suggestions for the guidance of dairymen. These cover the stabling, feeding, and care of cattle, and the care of milk.

The form used for making application for inspection is shown in Appendix IV (p. 189).

Recently more care in cooling and cleaner methods have obtained at dairies. It is stated that inspections should be more frequent and that the rules should be enforced requiring the "xclusion of unhealthy cows from dairy herds, the proper care and handling of milk, etc.

Phœenixville. (Population, 9,196.)

[For comparison with other cities in Class IV, see p, 42.]

E. M. Massinger, V. S., veterinary inspector.

The daily consumption of milk is estimated as 725 gallons, or 0.63 pint per capita, besides 30 gallons of skimmed milk and 10 gallons of cream. Milk is sold from is stores and 37 wagons. About one-third of the dealers deliver milk in glass bottles filled at the farms: nome is pastenrized. The retal price is 5 cents per quart through. out the year, producers receiving 2 to $2 \frac{1}{2}$ cents in summer and 3 to $3 \frac{1}{2}$ cents in winter. Within the city limits there are 7 herds, including about 60 cows, and milk is brought in wagons from 55 dairy farms, the longest haul being 5 miles.

An ordinance in effect July, 1894, refers to milk. License is required for the sale of milk. Impure, adulterated, ete, milk is prohibited, and may be destroyed. The milk standard is 12.5 per cent solids, 3 per cent fat, specific gravity not less than 1.029. Skimmed milk must be labeled and contain 2.5 per cent fat, 6 per cent of cream by volume.

About $\$ 200$ is expended in the supervision of the milk supply. During the past year 496 samples were examined by the lactometer, and 8 of the 55 dairy farms were inspected.

The inspector recomments an ordinamee excluding all tulerenlous cows from dairy herds. 


\section{RHODE ISLAND.}

General laws of 1896 , chater 147 ; amt laws of 1896 , chapter 333 ; and 1900 , chajter 785 , refer to milk, ete. The mayor and aldermen of any city and the council of any town may select milk inspectors; in Providence this is compuisory. Notice of the selection shall be published. Inspeetors shall record names and arldreseses of persons selling milk, take samples of milk supposed to the impure, etc. They may appoint sample collectors. Chiefs of police, milk insperetors, sperial constables, etc., may prosecute. The sale of milk from eow ferl upen distillery refuse or other deleterious substance, or milk from diseased rows or milk to which water or any foreign sulstance has been adrled, is forhidelen. The milk standart is 12 per rent solisls, 2.5 per cent fat. Skimmed milk nust be plainly labeled. The name and ardress of any person convicterl shall he mblisherl in his town or county. Milk is required to be sold by wine measure, and measures used in its sale must be sealed.

\section{Providence. (Population, 175,597.)}

[For Comparison with other eities in Class I, see p. 28.]

Walter $\mathrm{O}$. Scott, inspector of milk.

The daily receipts of milk is estimated as 22,000 gallons, or 1 pint per capita, besides a small anount of skimmed milk and quite a large amount of cream. The amount of milk consumed as such ean not be definitely stated herausta al large portion of the receipts is used in the butterine factories located in the city; also the ofticial records are kept in such a manner that milk which is wholesaled may be recorded more than once. Milk is sold from 1,200 shops and 500 wagons. Glass bottles are used in the delivery of 3 per cent of the milk and 99 per cent of the cream, the former being bottled at the producing farms and the latter in the city. Little or no attention is given to the pasteurization of milk. The retail price of milk is 5 to 8 cents per quart in summer and 6 to 8 cents in winter. There are 6 or 8 dairies in this locality conducted in a satisfactory manner, but not receiving an extra price for their milk. The number of cows in the city is not known. It is estimated that one-third of the total milk supply is receiver by railway, the longest shipment being 60 miles.

State laws are depended upon to regulate the milk supply.

The supervision of the riilk supply costs the city about $\$ 6,000$ annually. Four officials-an inspector, two collectors of samples, and one clerk- give their entire time to the work. During less than half of the past year 3,178 samples of milk were examined either by the Babcock test or gravimetric analysis, or both. During the year examinations were made of 200 samples to determine bacterial content.

According to the milk inspector, the percentage of milk-that is, adulteratedfound for sale in stores has fallen from $28.67 \mathrm{in} 1898$ to $11.79 \mathrm{in} 1901$, and in the same period the pereentage of alulterated milk found on wagons has fallen from 17.12 to 7.34. During this time the prosecutions averaged in number about 6 per month. The city milk inspector appenrs at prosecutions only as a witness. Milkmen are prosecuted without warning if their milk contains less than 11.50 per cent total soliks, and storekeepers are prosecuted without warning when their milk shows less than 11 per cent total solids, and after warning if below 11.5 per cent. The milk inspector's report contains much interesting matter regarding the production and handling of milk, and quite a full discussion of the work performed in his office.

Forms for keeping the recorils of the milk inspector's oftice by the "card system" are shown in Appendix IV (p. 210).

Needed improvements as given inclule the raising of the legal standard for milk to 3.5 per cent fat; the adoption of standards for cream and skimmed milk; the licensing of dealers so that dishonest persons an be kept out of the business; the 
delivery of milk to the consumer just as it is put up at the dairy or store, thereby preventing its being turned from one vessel to another on wagons in open air; the extablishment of a State dairy burean to have supervision of all the dairy interests of the State.

\section{Pawtucket. (Population, 39,231.)}

[For comparison with other eities in Class III, see p. 38.]

A. J. Johnson, jr., inspector of milk.

Estimated daily comsumption of milk is 2,955 gallons, or 0.60 pint per capita, besiles 75 gallons of skimmed milk. This is sold from 80 stores and 125 wagons. (ilass bottles, filled at the farms, are used largely in the delivery of milk. No milk is pasteurized. The retail price of milk is 5 to 6 cents per quart in summer and 6 to 7 cents in winter, producers heing paid 3 cents and $3 \frac{1}{2}$ cents, respectively. The milk from two "model dairies" is sold at 7 cents per quart throughout the year. There are no dairy herds in the city. Milk is sent in from 200 dairy farms. Only about 2 per cent is received by railway, the longest shipment being 5 miles.

About $\$ 400$ is expenderl annually by the eity in the supervision of its milk supply, the milk inspector giving a part of his time to this work. During the past year 300 samples of milk were examined by lactometer and gravimetric analysis; no hacteriological examinations were made; one dairy farm was inspected.

Recently the milk has improved in composition. It is recommented that milk dealers be licensed, so that the privilege to sell milk (an be denied those who evade the law.

\section{Woonsocket. (Population, 28,204.)}

[For comparison with other cities in Class III, see p. 38.]

William C. Mason, city clerk.

This city has no ordinance regulating its milk supply, and information on this subject is not obtainable.

\section{SOUTH CAROLINA.}

Acts of 1896, No. 96, sections 1 and 2, refer to milk. It is unlawful for any person knowingly to sell impure or adulterated milk or milk from animals aliseased or having ulcers, etc. The milk standard is 8.5 per cent solids not fat, 3 per cent fat. Skimmed milk and buttermilk, when sold, must not be misrepresented.

\section{Charleston. (Population, 55,807.)}

[For comparison with other cities in Class II, see p. 32.]

\section{J. Mercier Green, M. D; health ofticer.}

The daily consumption of milk is given as 720 gallons, or an average of 0.10 pint per capita, hesides 8 gallons of skimmed milk and 1 gallon of cream. In cxplanation of this apparently low ("onsumption, it is stated that many private families keep from 1 to 12 cows and dispose of milk and cream. The quantity of milk produced by these cows is unknown, and is not included in the above estimate. Milk is sold from ti wagons. Only a very small quantity of milk is deliveresl in ghlass bottles, and little or none is pastemized. The retail price of milk is 8 cents per quart throughout the year. There are no "model dairies" near the city. No milk is shipped in by railway, the greater part of it being brought in boats from the near-by islands.

The city expends nothing for milk inspection. During the past year the board of health made bateriologieal (xammations of 27 samples of milk; none of the herds within the city was insperted and only 1 dairy farm ontside the city was insinected.

The pastage and enforesenent of an ordinane regulating the procluetion and handling of milk is said to be much needed. 


\section{SOUTH DAKOTA.}

C. I'. Sherwood, State food and dairy commissioner, Desmet.

Laws of 1897 , chapter 65 , anended, and 1899 , chapter 89 , sections 23 to 29 , and an act approved March 7, 1901, refer to foods and milk. The fool and dairy commissioner shall enforce food and dairy laws, and may take sumples for analysis, ete. Chemists at State institutions shall analyze samples. Cows for production of market milk shall not be kept in an unhealthy condition or fed upon food that will produce impure or unwholesome milk. It is unlawful to sell, without fully informing the buyer, any food that is adulterated, which term is defined at length.

\section{TENNESSEE.}

Public acts of 1897 , chapter 45 , refers to foods, and prohihits the sale of any food that is adulterated, which term is defined at length.

\section{Memphis. (Population, 102,320.)}

[For comparison with other cities in Class I, see p. 28.]

Felix Paquin, chemist and bacteriologist.

The daily consumption of milk is estimated as 6,400 gallons, or 0.05 pint per. capita. Milk is sold from 40 stores (including hotels, ete.) and 168 wagons. There are no large milk depots in the city. Glass bottles are used in the delivery of about one-third of the milk, and they are filled at the producing farms. The entire product of one dairy is pasteurized, and finds ready sale. Consmers pay 6 cents per quart for milk throughout the year. There is one comparatively extra well conducted dairy in the locality which receives 8 cents per quart for its product. One hundred and eighty-eight dairy farms, having 3,554 cows, send milk into the city, quite a large amount of which is received by railway, the longest shipment being 527 miles.

According to reports there were within the city limits in the year 1899 , 105 herds, including 891 cows; 55 of these "herds" consisted of from 1 to 3 cows each, which were kept for private use, and there were 115 dairy farm, having 1,723 cows, sending milk into the city. The longest distance milk was then sent to the rity was 212 miles.

An ordinance passed in July, 1898, regulates the milk supply. Permit from the board of health is required for the sale of milk or any other dairy product. The permit number and name of dairyman must be shown on delivery wagons. The ordinance prohibits the sale of alulterated or unwholesome milk, including milk from animals diseased or kept under crowded or uncleanly conditions, or fed on distillery waste or other unhealthy food, or watered with polluted water; milk drawn from cows fifteen days before or five days after alving; milk which has been in containers that were dirty or were washed with polluted water; milk from which cream has been removed; and milk containing an antiseptic. The milk standard is 12 per cent solids, 3 per cent fat.

A copy of the milk ordinance is shown in Appendix I (p. 173).

About $\$ 1,200$ is expended annually in the supervision of the city milk supply. One chemist and bacteriologist and 1 inspector of dairies and collector of milk samples give a part of their time to this work. During the year 1,083 samples were examined by the Babeock test, chemical analysis, microscopically, and bacteriologically; 36 examinations were made for pus cells and the bacilli of tuberculosis and typhoid fever; and 153 dairy farms were inspected. For the adulteration of milk 46 warrants were issued, and fines to the amount of $\$ 710$ were imposed; 13 cows were destroyed on account of tuberculosis.

In the previous year 1,529 samples of milk were tester for fat by the Bahcork test 
and 486 samples were examined for water and total solid content, preservatives, and microscopically for foreign substances; 11 lacteriological examinations were made; all of the city herds and 13 of the 188 dairies ontside of the city. about which complaints had been made, were inspected; 49 warrants were iswled for alulterating, use of preservatives, etc.; $\$ 505$ in fines were imposed.

There has been great inprovement in the quality of milk since the city inspection commenced about three years ago. It was then common to find 50 per cent added water and the free use of preservatives. Needed improvements include more frequent inspection of dairy farms and herds, the nes of tubereulin where tuberculosis is susperted, more severe penalties for violation of the milk laws, and better methods of handling milk from its production to its sale.

Nashville. (Population, 80,865.)

[For comparison with other cities in Class II, see p. 32.]

Larkin Smith, M. D., eity health oflicer.

The daily consumption of milk is estimaterl as 6,502 galloms, or an average of 0.67 pint per capita. Milk is sold from 13 stores and 198 wagons. There are no herds of milch cows within the city limits. Milk is sent in from 193 dairy farms, including 3,401 cows. Only a very small portion is shipped in by railway, the longest shipment being 18 miles.

An ordinance regulates the milk supply. Permits for the sale of pure milk are issued free of charge. Adulterated, impure, etc., milk is prohibited. The milk standard is 12.5 per cent total solids. skimmed milk must he plainly labeled. Buttermilk may be sold.

During the past year 2,570 samples were eximined for total solids and preservatives; no bacteriological examinations were mate, and none of the dairy farms were inspected.

The permit for selling milk has printed upon it a full copy of the milk ordinance.

Knoxville. (Population, 32,637.)

No reply to inquiries was received.

Chattanooga. (Population, 30,154.)

[For comparison with other cities in Class III, see p. 38.]

C. A. Baker, clerk of the board of health.

This rity has no milk inspector, and information reararding its milk supply is not available.

\section{TEXAS.}

Penal (ode, 1895, page 80 , chapter 2, article $4: 3:$, defines the milk from a diseased cow as adulteraterl.

San Antonio. (Population, 53,321.)

[For comparison with other cities in Class II, see p. 32.]

F. Pascal, M. D., health oflicer.

The retail price of milk is 8 cents per quart in summer and 10 cents in winter. One dairy near the city is said to be conducted in an entirely satisfactory manner.

An ordinance adopted in July, 1901, refers to milk. Milk dealers must have a permit; fee, \$1. Each milk vehicle must bear a metal tag or plate furnished by the city clerk. The sale of adulterated milk is prohibited.

There is practically no supervision of the milk supply. 


\section{MILK SUPPLY OF TWO HUNDRED CJTIES.}

\section{Houston. (Population, 44,633.)}

[For comparison with other cities in Class III, see p. 38.]

J. B. Massie, MI. D., city health officer.

The estimated daily consumption of milk is 3,800 gallons, or 0.68 pint per capita, besides 100 gallons skimmed milk and 200 gallons of cream. This is sold from 3 stores and 109 wagons. Gilass bottles are not used in the delivery of milk. The retail price of milk is 5 cents per quart throughout the year. There are no dairies near the city conducted in an entirely satisfactory manner. Within the city limits there are 19 heris, including 269 cows, and milk is brought to the city in wagons from 128 dairy farms, the longest haul being 6 miles.

An ordinance adopted in May, 1900, governs the sale of milk. Separate permits are issued free for each place of general sale or storage. The sale of inpure, adulterated, etc, milk is prohibited. The milk standard is 12 per cent solids, 3.2 per cent fat. Carrying swill, garbage, ete., upon milk wagons is forloidden. Nilk coming from outside the city must he exposed for inspection. Condensed milk and buttermilk must be from pure milk. In condensed milk the milk solids shall be equivalent $t_{1}$ 12 per cent solids" in crude milk, and 26.5 per cent of the solids shall he fat.

About 8960 is expended annually ly the city in the supervision of its milk supply, one milk and dairy inspector giving his entire time to this work. During the past year 4,775 samples of milk were examined hy the lactometer and Bahcock test; no bacteriological examinations were mate; all the city herds and all the dairy farms were inspected.

Ordinance sections defining the terms adulterated, etc., and referring to milk brought into the city are given in Appendix I (p. 178).

There has been an improvement in the grade of cattle feed userl and in the care of cattle.

\section{Dallas. (Population, 42,638.)}

[For comparison with other cities in Class III, see p. 38.]

\section{J. H. Florence, health officer.}

The estimated daily consumption of milk is 5,250 gallons, or 0.98 pint per capita. Milk is sold from 3 stores and 175 wagons. Ten per cent of the milk is delivered in glass bottles, some filled at the farms, other in the city. One establishment in the (ity pasteurizes milk and the practice is increasing. Milk is retailed at 4 to 5 cents per (yuart throughout the year. There are no dairy herds within the city. IIlk is brought to the city in wagons from 150 dairy farms, within a radius of 8 miles.

The anount expented in the supervision of the eity milk supply is not kept separate from the other expenditures of the board of health. During the past year milk samples were examined by the lactometer; all the dairy farms were inspecter. The watering of milk and use of boric acid are common forms of adulteration.

Galveston. (Population, 37,789.)

[For comparison with other cities in Class 11I, see p. 38.]

C. H. Wilkinson, health physician.

Ahout 5 per cent of the milk is delivered in glass bottles, but none is pasteurized. Milk retails for as high as 15 cents per quart throughout the year. Within the city limits there are 10 herks, inclurling 50 cows. About 10 per cent of the total milk supply is received by railway, the longest shipment being 29 miles.

The eity has no milk ordinances, and exercises no supervision over its milk supply, but 8 of the city herds were examined during the past year.

As a means of improving the milk supply consumers are urged to patronize honest dairymen whose methods are cleanly. 
Fort Worth. (Population, 26,688.)

[For comparison with other cities in Class III, see p. 38.]

H. C. Whitehead, M. D., city health officer.

The city has no milk inspector and no regulations regarding the milk supply, except a general provision referring to milk exposed for sale.

\section{UTAH.}

Moroni Heiner, State dairy and food commissioner, Morgan City.

Laws of 1896, chapter 60, sections 1 to 5 , and laws 1897, chapter 54, refer to milk, etc. The dairy commissioner is chargerl with the enforcement of all laws concerning dairy products. County attorneys shall assist. It is unlawful to sell as pure any milk that is adulteraterl, skimmed, or impure, which includes milk from a cow within 20 days before and 5 days after parturition or from a cow that has a direase, ulcers, etc. Skimmed milk must be plainly marked; its standard is 9 per cent solids not fat. Standard tests and lactometers may be used to determine quality. Preservatives are prohibited.

Salt Lake City. (1'opulation, 53,5:31.)

[For comparison with other cities in Class II, see p. 33.]

Horace H. Smith, clerk of the board of health.

The daily consumption of milk is estimated as 2,300 gallons, or an average of 0.34 pint per capita. This is sold from 20 stores and 57 wagons. Seventy dairymen hold permits from the hoard of health. Abont two-thirds of the milk is delivered in glass bottles filled in the eity. Fifty per cent of the total supply is pasteurized and the practice is increasing. The retail price of milk is 5 cents per quart throughout the year, producers receiving 21 to 21 cents in summer and $2 \frac{1}{2}$ cents in winter. The milk from two esperially well-ronducted dairies is sold at the regular price. About 1,000 gallons of milk is producerl hy cows kept by private families. In addition to these there are within the city limits 25 herds, including 250 cows. The longest shipment of milk to the city by railway is 35 miles.

An ordinance adopted in August, 1894, amends a previous milk ordinance. Permits for the sale of pure milk are granterl after the premises, cows, and milk vessels have been inspeeted and a sample of the milk has heen analyzed. Yearly license fee shall be paicl as follows: On daily wales of not more than 2 gallons, 81 ; on daily sales of 2 gallons and not more than 5 gallons, $\$ 3$; on each arlditional 5 gallons or part thereof sold daily, 5.50. Adulteraterl, etc., milk is prohibited. The milk standard is total solids, 12 per cent; fat, 3 per cent; solids not fat, 9 per cent; ash, 0.68 per cent.

During the past year the office of food inspector was abolished, and there has since been very little supervision of the milk supply. Forty samples of milk were examined by the lactometer and Babcock test, and 15 were tested for preservatives.

The form for report upon inspection of dairies is shown in Appendix IV (p. 196).

Recent improvements in the milk are attributed largely to the decreased use of brewers' malt and the increase in the practice of pasteurization. The present need, as stated, is the instruction of milk producers in cleanly methods.

\section{VERMONT.}

Statutes of 1894, rections 43010, 48207 to 4331, and 4975; laws of 1898 , Nos. S1 and 115 , refer to milk, ete. No person shall sell milk that is diluted with water, adulterated, or skimmed. The milk standard is 12.5 per cent total solids, 9.25) per cent solids not fat, except $11 \mathrm{May}$ and June, when it is 12 per cent total solids. Results of analyses 
at the State auricuitural experiment station are competent evidence for prosecution. Milk tests for the basis of payments must be accurate, and persons making such tests must hold certificates. Wine measure is the standard measure. The state board of health is authorized to make chemical and bacteriological examinations of milk.

\section{VIRGINIA.}

Acts of 1899-1900-page 694 , chapter 655, refers to fooks. It provides that the State board of asciculture shall examine samples of foods and may pulblish results. It forbids the sale of any food that is adulterated, which term is defined at length.

\section{Richmond. (Population, 85,050.)}

[For comparison with other cities in Class II, see ]. 332.]

John A. Haley, secretary of the board of health.

The daily consumption of milk is estimated as 4,000 gallons, or an average of 0.38 pint per capita, hesides 100 gallons of cream. Milk is sold from 100 stores and 150 wagons. Glass bottles, filled in the city, are userl in the delivery of a small portion of the milk supply. No milk is pasteurized. The retail price of milk is 6 cents per quart throughout the year, producers receiving $3 \frac{1}{2}$ cents. There are no "model dairies" near the city, nor are there any dairy herds within the city limits. Milk is supplied from 150 dairy fatrms. Five per cent is received ly railway, the longest shipment being 35 miles.

There is no inspection of milk or dairies.

Norfolk. (Population, 46,624.)

[For comparison with other cities in Class III, see p. 38.]

A. P. Pannill, secretary of the board of health.

This city has no milk ordinance and no milk inspector, and does not exercise supervision over the milk supply.

\section{WASHINGTON.}

E. A. McDonald, State dairy and food commissioner, Seattle.

Laws of 1899-chapter 43 refers to milk, ete. It is the duty of the State dairy commissioner to enforce all laws relating to dairy products. Chemists at State institutions shall make analyses. Attorney-general and county attorneys shall give legal assistance. Persons selling milk in cities and towns must obtain a license annually in June, from the dairy commissioner, at a cost of s1. A separate license is reyuired for each rehicle, and the latter must show license number and owner's nane and business address. It is unlawful to sell as pure any milk that is impure, adulterated, or skimmed, including milk known to he from cows diseased or having ulcers, etc, or within fifteen days before and four days after jarturition; milk from cows kept in an unhealthy condition or ferl on distillery waste or other putrefying wr unhealthful sul)stance; milk exposed to contamination by persons or animals, or milk to wheh preservatives have been added. And it is unlawful to sell cream from mpure or diseased milk. The milk standard is 8 per cent solids not fat, 3 per cent fat. The eream standard is 18 per cent fat. Nkimmed milk may be sold only when plainly marked. Proprietors of dairies and all milk venders must report to the daury commissioner the amount of milk handled. Milk dealers must have their cans markerl to show capacity.

Laws of 1899-chapter 113 refers to foods. It forbids the sale of food that is adulterated, and this term is defined at length, 
There were 391 licenses issued by the dairy commissoner in the past year. By counties they were as follows:

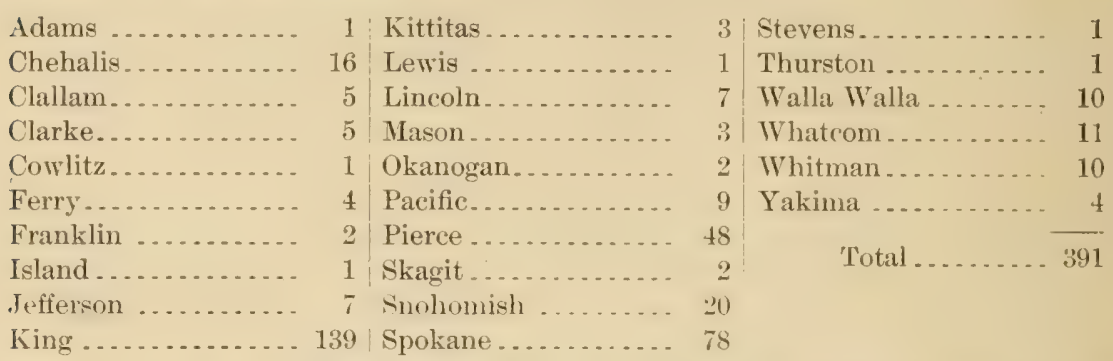

Forty-four samples of milk have been analyzed and all of them found to be unadulterated.

\section{Seattle. (Population, 80,671.)}

[For comparison with other cities in Class II, see p. 32.]

M. E. A. McKechnie, M. D., health officer.

L. M. Woodcock, milk and dairy inspector.

The daily consumption of milk is estimated as 9,200 gallons, or an average of 0.91 pint ler capita, besirle 400 gallons of skimmed milk and 700 gallons of cream. Milk is sold from 142 stores and 87 wagons. A very limited amount of milk is delivered in glass bottles, and these are filled in the city. Only one firm pasteurizes milk, and the practice is not increasing. The retail price of milk is is cents fer quart in smmmer and 7 cents in winter, producers receiving $2 \frac{1}{2}$ cents and $3 \frac{1}{2}$ cents in the two seasons. There are no "model dairies" near the city. Within the eity limits there are 21 herds, including 400 cows, and milk is sent in from 76 dairy farms. About two-thirds of the total milk supply is receiver hy ralway, the longest shipment heing $4+$ miles.

The milk standard is said to be 3 per cent fat, 9 per cent other solids.

About $\$ 1,200$ is expented amnually in the supervision of the city milk supply, one official-a milk and dairy inspector-giving hisentire time to this work. During the past year 2,400 milk samples were examinerl hy the Baboock test; 117 samples were analyzed gravimetrically; no bacteriological examinations were marle; all the city herds and all the dairy farms were inspected.

Recently there has been a marked decrease in the sale of adulterated milk. Needed improvements, as given, include hetter dairy huildings and greater care in the production and handling of milk.

\section{Tacoma. (Population, 37,714.)}

[For comparison with other cities in Class III, see [. 38.]

Harry H. Collier, deputy State dairy commissioner.

The number of cows supplying milk to Tacoma is 1,100 , and these are included in 21 herds. Two hundred and six milk samples were tested in six months in the past year.

\section{Spokane. (Population, 36,848.)}

[For comparison with other cities in Class I1I, see p. 33.]

James Bullivant, V. S., deputy State dairy commissioner.

The estimated daily consumption of milk is 2,500 gallons, or 0.54 pint per capita; also 200 gallons of eream. Milk is sold from 8 stores and 45 wagons. About onelifth of the milk is delivered in erlasy bottles, filled in the city, by 3 or 4 dealer. 
One dairy during the hot months pasteurizes milk. The retail price of milk is 6 cents per quart in summer and 8 cents in winter, producers receiving $3 \frac{3}{4}$ cents in the summer season. There are no "model dairies" near the city. Within the city limits there are 6 herds, including 200 cows. The longest shipment of milk to the city is 50 miles.

During the past year 650 samples of milk were examined by the Babcock test; all of the city herds but none of the dairy farms were inspected; and $1 \mathrm{cow}$ was examined for tuberculosis.

\section{WEST VIRGINIA.}

Code of 1891 , chapter 150 , section 20 , refers to foods. It is unlawful to sell any article of food or drink that is not what it is represented to be.

\section{Wheeling. (Population, 38,878.)}

[For comparison with other cities in Class III, see p. 38.]

S. L. Jepson, M. D., ex-health officer.

The daily consumption of milk is estimated as 4,000 gallons, or 0.82 pint per capita, besides a small quantity of skimmerl milk and 400 gallons of cream. Milk is sold from 140 stores and 120 wagons. Glass bottles are not used to a very great extent in the delivery of milk. They are filled some at the farms and some in the city. Milk is pasteurized only when preseriber by physicians. The retail price of milk is 6 cents per quart in summer and 8 cents in winter, producers receiving 3 and 4 cents, respectively. There are no "model diairies" near the city. Within the city limits there are 10 herds, including 100 (")ws, and milk is sent in from 125 dairy farms. About one-third of the milk is received by railway, the longest shipment being 30 miles.

The city has mo milk ordinane, and no supervision is exercised over its milk supply.

The health officer believes that all milk dealers should be licensed, a milk standard should be fixed, and dairies should be inspected by a city ufficial.

\section{WISCONSIN.}

H. C. Adams, State dairy and food commissioner, Madison.

The dairy laws have been compiled and in 1894 they were published in 22 sections by the State dairy and food commissioner. It is the duty of that officer to enforce laws regarding dairy products. County district attorneys shall assist. Necessary authority is given for inspections, samples may be taken (duplicate to owner when requested), etc. It is unlawful to sell as pure any milk that is impure, adulterated, or unwholesome, including diluted or skimmed milk, milk from a cow known to be within fifteen days before or four days after parturition, or having ulcers, etc. And it is unlawful to sell milk that was handled in unclean vessels, or milk from cows that are diseased, kept in unsanitary coulitions, or fed on unwholesome food, or refuse or slops from a distillery or vinegar factory, unlesw such slop "be mixed with other dry sanitary grain or food to a consistency of a thick mush;" or milk to which a preservative or any foreign substance has been added; but viscogen or sucrate of lime may be used to restore viscosity to pasteurized milk or cream if its use is made known. The milk standard is 3 per cent fat.

The sale of any adulterated ford is prohibited, such an article being defined at length.

So far as its limited force permits, the dairy and food commission cooperates with local authorities in the supervision of the market milk supply. Last year State 
anthorities marle examinations in Milwankee, Wausau, Janesville, Madison, Watertown, Racine, Kienosha, and Merrill. A few years ago brief statements of conditions fouml at dairies were published in the commissioner's annual report. The statements relating to two dairies-a good one and a poor one (names of persons being here omitted) - are as follows:

Number of ('ows, 32; condition of stock, good, clean; condition of stables, clean; utensils, clean; feed, brewers' grains, corn feed, clover hay; well water. A good, clean dairy. Inspected (second visit) April 7, 1898.

Number of cows, 9; condition of stock, very dirty, manure on hips and belly; condition of stables, dirty; utensils not seen; feed, brewers' grains, middlings, and hay; city water. Sickness prevented proper care; so informed by proprietor. No improvement since March 29, 1898. Drainage poor. Inspected February 27, 1899.

The commissioner's report shows, also, that a large number of samples of milk delivered to butter and cheese factories, as well as to cities and towns, have been examinerl for fat content. A few bacteriological examinations have been made by the bacteriologist of the State University.

It is estimated that not 10 per cent of the milk sold is delivered in glass bottles and probably not more than 1 per cent of the total is pasteurized; this latter treatment is increasing. The arerage retail price of milk in cities and towns varies from 4 to 6 cents. Nilwankee is the only city in which any considerable portion of the milk supply is handled by middlemen, and the country producers supplying that city receive an average of about $2 \frac{1}{2}$ cents per quart for their milk.

Recent improvements in the milk supply are due to better dairy cattle, producing a higher gratle of milk, and improved methods of caring for cows and handling milk.

\section{Milwaukee. (Population, 285,315.)}

[For comparison with other cities in Class I, see p. 28.]

W. C. Bennett, M. D., analyst.

The daily consumption of milk is estimated as 25,000 gallons, or 0.70 pint per capita, hesides 600 gallons of cream and an unknown quantity of skimmed milk. IIilk is sold from about 500 stores and 600 wagons. About one-tenth of the supply is delivered in glass bottles, and these are filled in the city. Trade in pasteurized milk is unimportant. The retail price of milk is 5 cents per quart in summer and 5 to 6 cents in winter, the producers receiving 2 cents in summer and 21 cents in winter. There are no "model dairies" in or near the city. Within the city limits there are 117 rairy herd, including fit:; head; the number of dairy farms sending milk into the city is unknown. About one-fourth of the entire supply is received by rail, the longest shipment being 72 miles.

An ordinance adopted hy the city council October, 1891, requires that each jerson dealing in milk shall procure a license from the health commissioner who must first be satisfed with the sanitary condition of the dairy premises of the applicant; license fe'e, s1. Covered delivery wagons must be used during the entire year. Adulterated and skimmerl milk, milk from cows fed on distillery waste or other unwholesome food, milk from any place where there is a contagious disease, or milk from tuberculous cow; is prohibitel. The use of wholesome brewers' grains is allowed. The milk stanlare is 12 jer cent solids, 9 per cent solids not fat. Inspectors are anthorizer to pour illegal milk upon the ground. Skimmed milk may be sold, if in vessels plainly labeled; it must contain 9 per cent solids not fat.

The ortinance section requiring covering on milk delivery vehicles is shown in Appendix I (p. 179).

About $\$ 1,500$ is expended amnually in the supervision of the eity milk supply, the entire time of no one officer being given to this work. During the past year a large number of rimples of milk were examined for fat content by the Babcock test; no 
samples were examined bacteriologically; 70 of the 117 leerls within the city limits were inspected; none of those out of the city were inspected.

There has been a slight improvenent in the compusition and cleanliness of milk. Vected improvements include the application of the tulerenlin test, so far as practicable; a municipal milk farm and laboratory to proulucenilk for infints' nse; more perfect control of the sanitary comditions at the dairies outsile of the city limits; more economical delivery, and an intelligent enforcement of the milk laws and ordinances.

Superior. (Population, 31,091.)

[For comparison with other cities in Class III, see p. 38.]

J. MI. Ruggles, secretary of the board of health.

Milk is sold from 2 stores and about +1 ) wagons. Alunt $2-7$ herds, including over 400 cows, are within the city limits, and milk is rent in from dairy farms as far distant as 140 miles form the city.

Board of health ordinanes, sections 47 to 52 , refor to milk. License fee for sale of milk is 50 cents for each store and (alch wagon. Adulterated, etc.. milk is prohib)ited. The milk stamlard shall from time to time he fixerl by the board of health, but is subject to change by the common council.

The meat and milk inspertor's monthly reint is mublisherl in the eity papers, and shows the names of dairymen visited, the number of cows kept by them, the percent of fat in their milk, the kinds of feed used, the surese wi water supply, and the general appearance of the stock and barns.

Racine. (Population, 29,102.)

[For comparison with other cities in Class 1II, see p. 38.]

Fred Pfister, health officer.

The estimated daily consumption of milk is 1,800 galloms, or 0.49 pint per cappita, besides 100 gallons of skimmerd nilk and 50 gallons of aream. Milk is sold from 20 stores and 40 wagons. About 15 per cent of the milk supply is delivered in glass bottles filled at the farms, hut none is pasteturized. The retail price of milk is 5 cents per quart throughout the year, froluers being paid 21 cents. There are no dairy herds within the city limits. Dilk is imought in wagons from 50 dairy farmo, the longest haul being 8 miles.

The city expends nothing in the supervision of its milk supply. During the past year 10 samples were examined hy the Babcrek test, lactometer, and pycmometer; no bacteriological examinations were made, and none of the dairy herds were inspected.

It is sail that several well-conducted dairies near the ('Ity, supplying milk to a proprietary fool company, have hy their example assisted in l ringing ahout improvements in other dairies.

La Crosse. (Population, 28,895.)

[For comparison with other cities in Class 1II, see p. 38.]

Richard D. Murphy, health ofticer:

The daily consumption of milk is estimated as 1,000 gallons, or 0.28 pint per capita, besides 100 gallons of skimmed milk and 100 gallons of (ream. Milk is sold from 50 stores and 30 wagons. Five per cent of the milk is delivered in glass bottles tilled at the farms. None is pasteurized. The retail price of milk is 5 cents per quart throughout the year. The milk from one "model dairy" is sold tor 6 cents per quart. Milk is sent in from 16 dairy farms, all within $1 \frac{1}{2}$ miles of the city.

The city exercises no supervision over its milk supply. 
Oshkosh. (Population, 28,284.)

No reply to inquiries was received.

\section{Greenbay. (Population, 18,684.)}

[For comparison with other cities in Class IV, sce p. 42.]

F. H. Thibodo, health officer.

The daily consumption of milk is estimated as 600 gallons, or 0.26 pint per capita, besides 60 gallons of (rean. In explanation of this apparently low eonsumption it is stated that a great many families keep their own cows, and the milk from these is not included in the alove estimate. Milk is sold from 1 store and 28 wagons. Several dairymen deliver milk in glass hottles, and these are filled at the farms. The retail price is 5 cents per cuart throughont the year, producers receiving 3 cents. There are no "model dairies" near the city. Within the city limits there are 8 herds, including 120 cows, and milk is brought in wagons as far as 8 miles.

Ordinance of June, 1894, and hoard of health rulew, March, 1894, sections 10 to 17 , refer to milk. License fee for the sale of milk is 82 , but persons keeping 1 or 2 cows in the city are exempt. Detivery wagons nust be covered from $A$ pril 1 to December 1. Impure, adulterated, $14 \cdot$, milk is prohibited. The standard is 12 per cent solids, 9 per cent solids not fat. Skimmed milk must be labeled and contain 9 per cent solids not fat. Cows nust be given wholemome food and water. Employees must be free from contagious disease. Dairy premises and apparatus must he kept clean. Milk tickets must not be taken from a plate where a contagious disease exists.

The health department has supervision over the milk supply. During the past year 12 samples of milk were examined hy lactometer and Babcock test and doubtful samples by gravimetric analysis; no bacteriological examinations were made; all the city herds and 20 dairy farms were inspected.

Recent improvement in the quality of the milk is due to a better grade of cows.

\section{Marinette. (Population, 16,195.)}

[For comparison with other cities in Class IV, see p. 42.]

\section{T. J. Redelings, health commissioner.}

The daily consmuption of milk is estimated as 464 gallons, or 0.29 pint per capita, besicles 12 yallons of crean. In explanation of this low consumption of milk it is stated that about 200 cows are kept by private families, and the milk from these is not included in the above estimate. Milk is sold from 3 stores and 23 wagons. Very little of it is delivered in glass bottles, and these are filled at the farms. Some families fastenrize their own milk supply. The retail price of milk is 5 cents per quart in summer and 6 cents in winter, producers selling their own product. There are no "model dairies" near the dity. Within the dity there are 8 herds, including 105 cows, and milk is sent in from 15 dairy farms (237 cows). About one-tenth of the supply is received by railway, the longest shipment being 96 miles.

Ordinance No. 117, July, 1901, having 26 sections, refers to milk. License fee for the sale of milk or cream is $\$ 1$ for each wagon, store, etc; each wagon after the first, \$1. Licenses are issued only after the health commissioner is satisfied with the sanitary comditions of the dairy premises. Impure, adnlterated, etce, milk is prohibiterl. The milk standard is 12 per pent solisls, a pere cent solick not fat. Skimmed milk must be labeled and contain 9 per cent solids not fat. Sour milk must be labederl. Milk vehicles mut he overed from 1 pril 1 to December 1 . Stables must. he whitewashed once a year. Cows must he fed upon wholesome food and be given pure water; be insweted in Jamuary, July, and September of each year; and every April they must be tested with tubereulin. The ordinance includes 15 rules regard- 
ing the management of dairies. Milk tickets must unt he taken from places where there is a contagious disease, and the commutation, or punch, ticket must be userl.

The health commissioner supervises the milk suplyly. During the past year 82 samples were examined by lactometer and Babcock test. No bacteriological examinations were made. All the city herds and all the dairy farms were inspecter. of 105 cows voluntarily subjected to the tubereulin test, 6 reacted and were killed by State officers.

Recent improvement is due to cleanliness at stables am the prompt cooling of milk. Needed improvements as given include the extahlishment of sterilizing stations for all milk, the use of the tubereulin test for all cows, and the sprearling of information relating to the care of dairies.

Waukesha. (Population, 7,419.)

[For comparison with other cities in Class IV, see p. 42.]

Hugo Philler, M. D., health commissioner.

The daily consumption of milk is estimated as 395 gallons, or an average of 0.43 pint per capita. Milk is sold from 15 wagons, and alsut one-fifth of it is lelivered in glass bottles. Very little milk is pasteurized, and the practic't is not increasing. The retail price is 6 cents per quart thronghont the year. Within the city limits there are 2 herds, including 40 cows, am milk is sent in from 13 dairy farms within 3 miles of the city limits.

About $\$ 150$ is expended ammully toward the supervision of the milk supply as the salary to the health commissioner. During the past year 350 samples of milk were examined by lactometer and Babcock test, special attention being giren to preservatives; and 3 samples were examined bacteriologically for tubercle bacilli.

\section{WYOMING.}

Rerised statutes, 1899, sections 2644,5109 , and 5110 , refer to milk and fords. Milk is exempted from the list of articles that can not be sold on Sundays. The adulteration of any article of foud or drink with fraudulent intent or sale of same or knowingly selling any unwholesome article of food or drink is a misdemeanor.

\section{APPENDIX I.}

The following are the milk ordinances entire of six cities, and miscellaneous selected sections from numerous others:

\section{New York City.}

The following are sections from the Sanitary Code, and regulations and rules as published by the board of health of the city of New York:

Extract from Sanitary Code of Laws Governing the Sale of Milk.

SECTrox 59. That no person shall have at any place where milk, hutter, or cheese is kept for sale, nor shall at any place, sell, deliver, or offer, or have for sale, or keep for use, nor shall any perwon hring or send to said eity any unwhlesone, skimmed, watered, or adulteraterl milk, or milk known as "swill milk," or milk from (")ws or other animals that for the most part have been kept in stables wr that have been fed in whole or in part on swill, or milk from sick or diseaserl cows or other animals, or any butter or cheese marle from any such milk, or any unwholesome butter or cheese. 
SEc. 63. No milk which has heen watered, adulterated, reduced, or changed in any respect by the ardition of water, or other substance, or by the removal of cream, shall be brought into, held, kept, or offered for sale at any place in the city of New York, nor shall anyone keep, have, or offer for sale in the said city any such milk.

The term "adulterated," when so used in this section, means:

First. Milk containing more than 88 per cent of water or fluids.

Second. Milk containing less than 12 per cent of milk solids.

Third. Milk containing less than 3 per cent of fats.

Fourth. Milk drawn from animals within fifteen days before or five days after parturition.

Fifth. Milk drawn from animals ferl on distillery waste, or any sulstance in a state of fermentation or putrefaction, or on any unhealthy food.

Sixth. Milk drawn from cows kept in a crowded or unhealthy condition.

Seventh. Milk from which any part of the cream has been removed.

Eighth. Milk which has been adulterated with water or any other fluid, or to which has been added, or into which has been introduced, any foreign substance whatever.

SEC : 64. Any milk found to be arlulterated, either by the addition of water or other substances, or by the removal of crean, or which has been lrought into, or is held or uffered for sale in the city of New York contrary to the provisions of section 6:3 of the Sanitary Code, may beseized and destroyed by any inspector, or other officer of this department authorized to inspect milk.

SEC. 65. Nocondensed milk which is adulterated shall he brought into, held, kept, or offered for sale at any place in the city of New York, nor shall anyone have, keep, or offer for sale in said city any such condenserl milk. The words " condensed milk" mean pure milk from which any part of the water has been removed, or pure milk from which any part of the water has been removed and to which surars have been added. The term "arlulterated," when used in this section, refors to condensed milk in which the amount of fat is less than 25 per cent of the milk solids contained therein, or to which any foreign substance whatever has been arded, excepting sugars, as in preserved milks.

SEC , 66. No milk shall be receiver, held, kept, offered for sale, or delivered in the city of New York without a permit in writing from the board of health and subject to the conditions thereof.

SEc. 67. No cream that is adulterated shall he brought into, held, kept, or offered for sale in the city of New York, mor shall anyone keep, have, or offer for sale in sair city any such cream. The term "cream" means the fatty portions of pure milk which rise to the surface when the milk is left at rest, or which is separated hy other means. The term "adulterated," when used in this section, refers to cream to which any foreign substance whatever has been added.

\section{REGULATIONS.}

(1) Milk shall not be kept for sale or stored in any room used for sleeping or domestic purposes or opening into the same.

(2) Milk must not be transferred from cans to bottles or other vessels on streets or on ferries or at depots, except when transferred to ressel of purchaser at time of delivery.

(3) Milk shall not be sold in bottles except under the following rules:

Bottles must be washed (lean with a hot water solution of soap, or soda, or some other alkali, and then with hot water before filling with milk.

Bottles must not be filled exeept at the dairy or creamery, and in the city only in rooms so mituaterl as to prevent the contamination of the milk by dust from the streets or other impurities. 
Bottles must not be washed or filled with milk in any rom userl for sleeping or domestic purposes or opening into the same.

(t) The ressel in which milk is kept for sale must be so protecterl by means of a suitable eover or covered receptacle and so placed in the store as to prevent dust from the street or other impurities falling into it.

(5) Store permits must be posted in stores so that they (an he eavily seen at all times.

(6) Wagon permits to be carried on the wagons at all times when engaged in the sale, transportation, or delivery of milk.

(7) The number of wagon and the number of permit, the latter to be precerded by the words "Department of Health Permit," must he painted on both silis of the wagon in letters.2 inches in length and one-half inch in width, and in some contrasting color to that of the wagon.

(8) If any changes are made in the information given on application blank, the department must be immediately notified.

\section{Rules for Handing and KeEping Milk.}

(1) Milk should be kept in some place where dust and other impurities can not fall into it, such as a box with tight-fitting cover-preferably an ice box.

(2) The milk should be kept at as low a temperature as posible, not above $50^{\circ} \mathrm{F}$.

(3) After the day's sales are over, the measures and utensils usert in the sale of milk should be thoroughly cleaned with boiling water, to which a small amount of soda has been added in the proportion of one tablespoonful of washing solla to a gallon of water.

(4) The overflow pipe from the ice box in which the milk is kept must not be connected directly with the drainpipe or sewer, but must discharge into an open, water-supplied, properly-trapped, sewer-connected sink. (See section $t 1$ of the Sanitary Code.)

(5) The ice box in which the milk is kept should be cleaned, by scrubbing ont with hot soda solution made as in No. 3, at least twice a week.

(6) In selling milk, stir up the contents of the can thoroughly before measuring ont the amount desirerl. This will prevent unintentional skimming. In this way the last quart of milk sold from the can will contain as much cream as the first quart sold.

(7) It sometimes happens that in cold weather the milk may be delivered to the dealer more or less frozen. If such is the case, detach the ice from the side of the can and gently heat the contents until the ice is all melted. If there is much ice in the can it is absolutely necessary to do this before selling the milk, otherwise the lipuid part dipped out and sold at first will contain more of the solic part of the milk and cream, while the ice remaining and consisting principally of water will after a time melt, and the result will be milk containing more water than pure milk, and this might be enough to appear as though the milk had been adulterated with water.

(8) Do not place ice in the milk if it is desired to cool it or keej it cold, as the ice will melt and you will then have adulterated the milk with water.

\section{City of Washington, D. C.}

Regulations for the Government of Dairies and Dairy Farms.

\section{Office Commissioners of the District of Columbia, Washington, July $31,1897$.}

Ordered, That the following regulations made by the health officer of the District of Columbia, pursuant to the requirements of section 11 of "An act to regulate the sale of milk in the District of Columbia, and for other purposes," approved March 2, 
1895, in lieu of the regulations on the same subject made and approved June 26, 1895, are hereby approved:

Section 1. No building or space shall the used for dairy purposes which is not well lighted and ventilated, which is not provided with a suital, le floor, and, if such room or space be a cellar or subcellar, or be locater in a cellar or subellar, which is not properly concreted, guttered, and drained.

SEC. 2. No dairy shall be located or maintained within any kitchen, wash room, work shop, or inhabited room, nor in proximity to any water-chet, privy, cesspool or urinal, nor in any room or space which is not of such size and construction as to permit the entire separation of all milk and milk products, both in the process of handling and storing the same, from all probable sources of contamination, either by dirt, noxious gases, infective organisms, or substances or anything liable to alter unnecessarily the quality of such milk or milk products.

SEc. 3. Every person maintaining a dairy shall provide for the use thereof, and shall use, a sufficient number of receptacles, marle of nonalsorhent material, for the reception, storage, and delivery of milk, and shall (ause them to be kept clean and wholesome at all times; and having delivered any such receptacle to a consumer shall not again use the same for the reception, storage, or delivery of milk or cream in any form until it has been, to his personal knowledge, properly cleaned after such use.

SEc. 4. Every person maintaining a dairy shall provide for the we thereof a supply of pure and suitable water, sufficient for the proper washing of all cans, bottles, and appliances.

SEc. 5. Every person maintaining a dairy thall keep the same and all appurtenances thereto clean and wholesome at all times, and shall change the water in the coolers at least once each day.

Sec. 6. No building shall he used for stabling cows for dairy purposes which is not well lighted, rentilated, drained, and constructed, or which is not provided with stalls or with proper stanchions for anchoring the (ows so) arranged as to allow not less than three and one-half feet width of space for each milch cow; or which is not provided with good and sufficient facilities for feeding the animals in a cleanly manner; or which contains less than six hundred culic feet clear space for each cow, unless the use of such building for stabling cows for dairy purposes has been authorized prior to the promulgation of these regulations, in which case it shall contain not less than five hundred cubic feet clear air space for each cow.

SEc. 7. No room shall be used for stabling cows for dairy purposes which contains any water-closet, privy, cesspool, urinal, or manure pit; nor shall any fowl, hog, horse, sheep, or goat be kept in any room used therefor.

SEc. 8. Every person using any premises for keeping cows for dairy purposes shall, when so directed by the health oflicer, erect and maintain in the stable, stall, shed, or yard commected therewith one or more proper receptacles for drinking water for such cows, and shall keep the same supplied with clean, fresh water and none other.

SEc. 9. Every person using any premises for keeping cows for dairy purposes shall keep the entire premises clean and in good repair and the buildings well painted or whitewashed.

SEc. 10. Every person using any premises for keeping cows for dairy purposes shall cause the dung to be removerl from the stables at least twice daily, and always within one hour preceding every milking of the cows; and shall not allow any aceumulation of dung within the building oceupied hy the cows, but shall, whenever in the opinion of the health officer it is reguired by local conclitions and surroundings, provide temporary storage for the same and for other refuse in a separate place, which shall be covered, and which, when $\mathrm{x}$ ordered hy sat health ofticer, whall be a water-tight receptacle.

SEc. 11. Every person keeping cows for dairy purposes within the eity of Wash- 
ington or its more densely populater suburbs, or elsewhere in the I)istrict of Columbia, if, in the opinion of the health officer, local conditions require it, shall cause the inclosure in which such cows are kept to be graded and drainerl so as to keep the surface reasonably dry and to prevent the accumulation of water therein, except as may be permitted for the purpose of supplying drinking water; and shall not permit any garbage, urine, fecal matter or similar substance to be placed or to remain in such inclosure, nor any open drain to run through it.

SEc. 12. Every person keeping cows for the production of milk for sale shall cause them to be kept clean and wholesome at all times, and shall canse the teats, and, if necessary, the udder, to be carefully cleaned by brushing, washing, or wiping before milking, and shall cause each such cow to be properly fecl and watered.

SEC. 13. Any person using any premises for keeping cows for dairy purposes shall provide and use a sufficient number of receptacles, of nonabsorlent material, for the reception, storage, and delivery of milk, and shall keep then clean and wholesome at all times, and at milking time shall remove each receptacle, as som as fillerd, from the stable or room in which the cows are kept; nor shall any milk or cream be stored or kept within any room used for stabling cows or other domestic animals.

SEC. 14. It shall be the duty of every person having charge or control of any premises upon which cows are kept to notify the health ofticer of the District of Columbia of the existence of any contagions or infections disease among such cows, by letter delivered or mailed, within twenty-four hours after the discovery thereof, and to thoroughly isolate any cow or cows so diseased or which may reasnnaly be believed to be infected, and to exereise such other precautions as may he directed, in writing, by said health officer.

SEc. 15. Niilkers and those engaged in the handling of milk or eream shall maintain strict cleanliness of their hands and persons while nilking and while so engaged. It shall he the duty of every person holding a permit to maintain a dairy or dairy farm to enforce this regulation in reference to such persons as may assist them in the maintenance thereof.

SEc. 16. That any person violating any of the foregoing regulations shall, on conviction thereof in the police court, be punished by a fine of not more than ten dollars for each and every such offense, to be collected as other fines and penalties are collected.

SEc. 17. That the regulations for the government of dairies or dairy farms in the District of Columbia promulgated June 26, 1895, are hereby repealed."

\section{Louisville, $\mathbf{K y}$.}

ss Be it ordained by the general council of the city of Louisville:

Section 1. That no person shall bring or send into the city for sale any milk without a permit to do so from the health officer, said permit to be furniwhed gratuitously by the health officer to all applicants, and to be renewed in the month of January of each year to be valid.

SEc. 2. All milk wagons shall have the name of the owner am the number of the wagon or vehicle painted thereon plainly and legibly.

SEc. 3. All grocers, bakers, and other persons having or offering for sale milk shall at all times keep the name or names of the dairyman or dairy company from whom the milk for sale was obtained posted up in a conspicuons place wherever such milk may be sold or kept for sale.

SEC. 4. No milk which is unwholesome or which has been watered, aclulterated, reduced, or changed in any respect by the addition of water or other substance, or by the removal of cream, shall be brought into, held, kept, or offered for sale at any

" The milk and food laws of the District of Columbia are published in full on pages 576-581 of the Fourteenth Annual Report of the Bureau of Animal Industry. 
place in the city of Lonisville, nor shall anyone keep, have, or offer for sale in the said city any such milk, except as provided for in this ordinance.

Sec. 5. The terms "adulterated or unwholesome," as used in this ordinance, are held to mean in this ordinance:

First. Milk containing more than 88 per centum of water or fluids.

Second. Milk containing less than 12 per centum of milk solids.

Thirl. Milk containing less than 3 per centum of fats or laving a specific gravity of less than 1.029 .

Fourth. Milk drawn from animals within fifteen days before or ten days after parturition.

Fifth. Milk drawn from animals fed on distillery waste, or any substance in a state of fermentation or putrefaction, or on any unhealthy food or drink.

Sixth. Milk drawn from cows kept in a crowded or unhealthy condition.

Seventh. Milk from which any part of the cream has been removed.

Eighth. Milk which has been adulterated with water, or any other fluid, or to which has been artled, or into which has been introduced, any foreign substance whatever.

Ninth. Cream sold or offered or kept for sale as such must contain at least 20 per rentum butter fat.

SEC. 6. No dealer in milk, by himself or his agents, shall sell, or have in his possession with ntent to sell, milk from which cream has been removed in part or in whole, unless sold as skimmed milk, and unless there shall appear in a conspicuous place on both sides of the rehicle from which such milk is sold the words "Skinmed milk," distinctly and legibly made in letters not less than 1 inch in height; nor shall any dealer in milk, nor his agent or agents, sell as skimmed milk any milk which has a less pereentage of rasein and salts than that containes in unskimmed milk.

SEC. 7. Every dealer in milk selling such skimmed milk shall, on each and every vessel from which he sells, have attached in front and side a notice stating in legible letters that such skimmed milk is for sale.

SEC. 8. Any person who offers for sale milk, skimmed or unskimmed, in the eity of Lonisville, whether a resiclent or nomresident, shall furnish a sample of such milk to any officer representing the health repartment of the city of Lonisville who may request the same for the purpose of examination or analysis.

SEc: 9. No dealer in milk, or his agents, shall serve milk in bottles to any dwelling or other house that has in it any contagions disease or diseases, or that is placarded hy the health officer for contugious diseave or diseases, until said placard has been removed hy the proper authorities; nor shall any person remove from such dwelling or house any bottle or receptacle which has been or is used for the purpose of receiving or storing milk. No person suffering from, or who has knowingly, within a period of twenty days, heen exposed to, diphtheria, scarlet fever, erysipelas, smallpox, or other dangerous contagions disease, shall work or assist in or about any dairy or dairy farm; no proprietor, manager, or superintentent of any dairy or dairy farm who supplies milk to the citizens of Lonisville, Ky, shall knowingly permit any person suffering, or exposed as aforesaid, to work or assist in or alout said dairy or dairy farm.

SEC. 10. The health ofticer shall unt iswne a permit to any person to sell milk in the eity of Louisville who does not furnish once in every three months the health department with a certificate from a duly gualified veterinary surgeon to the effect. that the eattle from which the milk he proposes to sell is obtained are entirely free from disease, and said certificates shall le kept on file in the health department, and shall embrace a descriptive enumeration of the cattle examined. The health oflicer may rexuire the tubermlin test if any herd is suspected of infection with tuberculosis.

SEC. 11. Exery person maintaining a dairy shall keep the same and all appurte- 
nances thereto clean and wholesome at all times, and shall change the water in the coolers at least once in each day, and no building or space shall he user for dairy purposes which is not well lighted and ventilated and which is not provided with a suitable floor and properly dramed, or which eontains less than 600 cubie feet clear space for each cow.

SEC. 12. Every person using premises for keeping cows for dairy purposes shall keep the entire premises clean and in good repair and the hulldings well painted or whitewashed, and no accumulation of dung shall he allowed, hut shall he remover at least twice daily, and one hour preceding every milking of the cows.

SEC. 13. Vilkers and those engagerl in the handling of milk or cream shall maintain strict eleanliness of their hands and persons while milking or while so engaged.

SEc. 14. Every person keeping cows for the production of milk for sale shall cause them to be kept clean and wholesume at all times, and shall cause the teats, and, if necessary, the udder, to be carefully cleamed by brushing, washing, or wiping hefore milking, and sha:l cause each of such cows to be properly fed and watered.

Sec. 15. Any person using any prenises for keeping cows for dairy purposes shall provide and use a sufficient number of receptacles of nonalsorbent material for the reception, storage, and delivery of milk, and shall keep them clean and wholesome at all times, and at milking time shall remove each receptacle as som as filled from the stable or room in which the cows are kept; nor shall any milk or cream be stored or kept within any room neet for stabling cows or other domestic animals.

SEC. 16. It shall be the duty of every lerson having charge or control of any premises upon which cows are kept to notify the health officer of the city of Lonisville, of the existence of any contagious or infectious disease among such cows, by letter delivered or mailed within twenty-four hours after the disovery thereof, and to thoroughly isolate any cow or cows so diveased, or which he maty reasonably believe to be infected, and to exereise such other precautions as may be lirected, in writing, by said health officer.

SEC. 17. All dairies from which milk is offered for sale in the city of Louisville shall be open at all times to the inspection of the health officer of the eity of Louisville, or any officer representing him.

Sec. 18. That any person, firm, company, or corporation who shall violate any of the provisions of this ordinanee shall he fined for earh offense not leses than $\$ 20$ nor exceeding $\$ 100$.

SEc. 19. This ordinance shall take effect from and after its passage.

\section{Indianapolis, Ind.}

Rules and Regulations for tme Cark and Managentent of Dairies Adopted by the Board of Public Health and Charities.

(1) No building shall be user for stabling cows for dairy purposes which is not well lighted, ventilated, drained, and constructed.

(2) No building shall be userl for stabling cows for dairy purposes which is not provided with a suitable floor, laid with proper grades and channels to carry off all drainage. If a public sewer abuts the premises upon which such builings are situated, they shall be connected therewith and furnished with proper sanitary traps.

(3) No building shall be used for stabling cows for dairy purposes which is not provided with good and sullicient feeding troughs or boxes, and with a covered watertight receptacle outside the building for the reception of dung or other refuse.

(4) No water-closet, privy, cesspool, urinal, inhabited room, or workshop shall be located within any building or sherl used for stabling cows for dairy purposes or for the storage of milk or cream; nor shall any fowl, hog, horse, sheep, or goat be kept in any room used for such purpose.

(5) No space in buildings or sheds used for stabling cows shall be less than 500 cubic feet for each cow, and the stalls therefor shall not be less than 4 feet in width. 
(6) It shall be the duty of each person ming any prenisery for keeping cows for dairy purposes to keep such premises thoroughly dean and in gond repair and well painted or whitewashed at all times.

(7) It shall be the duty of each person using any premises for keeping aws for dairy purposes to cause the huilding in which cows are kept to he thoroughly cleaned and to remove all dung from the premises, so as to prevent its accumulation in great quantities.

(8) Every person keeping cows for the production of millk for sale shall cause every cow to be cleaned every day and to be properly fed and watered.

(9) Every person using any premises for keeping cows shall canse the yard used in connection therewith to be provided with a proper receptacle for drinking water for such cows; none but fresh, clean water to be used in such receptacle.

(10) Any inclosure in which cows are kept shall the grated and drained so as to keep the surface reasonably dry and to prevent the accumulation of water therein, except as may be permitted for the purpose of supplying trinking water; no garlage, urine, fecal matter, or similar substances shall be placerl or allowert to remain in such inclosure, and no open drain shall be allowed to run through it.

(11) Any person using any premises for keeping cow for dairy purposes shall provide and use a sufficient number of receptacles, marte of nonahorbent materials, for the reception, storage, and delivery of milk, and shall cause all milk to be removed without delay from the room in which the cows are kept.

(12) No milk shall he kept in ice hoxes or refrigerators which are in any way connected with sewers or cesspools, nor shall any milk be kept in the same compartment of any ice hox or refrigerator in which meats or other articles of foud are kept.

(13) All cans, measures, and other recentacles fur milk whall he stullexl with boiling water or live steam daily; they must not he rinserl in cold water hefore using, for the water may not he pure, and some of it remaining in the vesels nay contaminate the milk. All milk cans coming from dairies to dealere must he projerly cleaned as above before returning to producer, thoroughly airenl, and kept turned upside rown in a cool place.

(14) All milk shall be strained through wire-eloth straines and shall be cooled to $58^{\circ}$ within forty-five minutes after it is drawn from the cow. In winter weather said cooler shall he guarded against freezing. The milk whall nut exeerel $60^{\circ}$ when delivered to the consumer or dealer.

(15) All milk cans delivered to creameries or dealers in the city shall be covered with air-tight lids, and when conveyed in open wagons shall be covered with (anvas while being so conveyed; said canvas to be kept clean by frequent washing.

(16) All stripping, as well as first part of milk, shall be delivered. The night's and morning's milk shall not tre mixed. To milk shall he deliverest that is taken from a cow that has calved within twelve days or from a cow that will come in or calve inside of sixty days.

(17) Cows shall not be ferl on feed which will inmart a disagreeable flavor to milk or upon any food which will not produce milk of a standard richness, or any sour, damaged feed or ensilage.

(18) It shall be the duty of any person having charge or control of any premises upon which cows are kept to notify the secretary of the hoard of health of the existence of any contagions or infections diveare amoner such cows immediately upon the discovery thereof, and to thoroughly isolite any cow or aws affected, and to exercise such other precautions as may be directed, in writing, by the said secretary.

(19) It shall be the duty of any person owning or having control of cows used for the production of milk for sale or exchange to submit sald (ow to the tubereulin test for tuberculosis on the written orter of the secretary of the heari of health.

(20) It shall be the duty of any person having charge or control of any premises

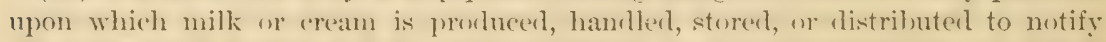
the secretary of the board of health immerliately upon the discovery of any ase of 
Asiatic cholera, cruup, diphtheria, measles, membranous croup, scarlet fever, smallpox, typhoid fever, typhus fever, or any other contagious or infections diseases upon such fremises. No milk or eream shall be sold, exchanged, given away, or in any other manner distributed from such infectious premises until all danger of spread of disease shall he removed and the secretary certifies to that effect. No person who attends cows or milks them, or who has the care or handling of vessels for the sale, storage, or clistribution of milk or cream, shall enter any place or premises wherein exists any of the diseases mentioned herein; nor shall any such have any communication, direct or inclirect, with any person who revides in or is an occupant of such infected place. Strict cleanliness of the hands and person of milkers and those engaged in the handling of milk or cream, and of the bodies of cows, especially of the udders and teats, numst be enforced at all times, to the end that no impurity or foreign substance may be adderl to the milk or cream, such addition being declared adulteration by the statute.

(21) No person shall add water or any other foreign sulstances to milk or cream offered or intended for sale or exchange. Milk offered for sale as whole milk or sold as such which contains more than 87 per cent of watery fluid or less than 13 per eent of milk solids, including $3 . \overline{7}$ per cent of butter fat, $a$ is prima facie watered, and such watering is declared an alulteration by the ordinance, the punishment for which is a fine of not less than $\$ 25$ for each and every offense.

\section{Memphis, Tenn.}

Milk Ordinance. ${ }^{\varpi}$

\section{Be it oidained by the legislative council of the city of Memphis, That-}

SECTion 1. No milk, buttermilk, or cream, or other dairy products shall be receiverl, held, kent, offered for sale, or lelivered in the city of Memphis without [the dealer] first obtaining a permit in writing from the board of health, and subject to the conditions thereof.

SEC. 2. No person shall have at any place, sell, deliver, or offer for sale, or keep for use, or bring or send to said city, milk or other dairy products which are unwholesome or adulterater with any substance, or from diseaserl animals, or from animals which are kept in uncleanly and unsanitary stables or stable yards, or from animals which are ferl on distillery waste or other unwholesome food, or watered with polluted water, or from dairy farms or other places where attendants are affected with or exposed to contagious or infectious diseases.

SEc. 3. Milk shall be termed unwholesome-

(a) When drawn from animals within fifteen days before or five days after parturition.

(b) When drawn from animals fed on distillery or other unhealthy food or watered with polluted water.

(c) When drawn from animals kept in a crowded or in unhealthy conditions.

(d) When obtained from dairy farms or other places where attendants are affected with or exposed to contagious or infectious diseases.

SEc. 4. Milk shall be termed adulterated-

(a) When it contains more than 88 per cent of water or other fluid.

(b) When it contains less than 12 per cent of milk solids.

(c) When it contains less than 3 per cent of fats.

(d) When water, or antiseptic, or other substance has been added.

(e) When any part of the cream has been removed.

(f) When placed in containers which are dirty or have been washed with polluted water.

a The milk standard has heen lowered by a State law to 12 per cent solids, 3 per cent fat.-H. E. A.

$b$ This ordinance is printed on the reverse side of the milk license. 
SEC. 5. It shall be the duty of the sanitary officers to obtain samples of milk, buttermilk, or cream from milk dealers whenever requested to by any citizen or orilered to do so by the hoard of health; sairl samples, together with name and address of dealers or drivers, are to be sent to the city chemist for analysis.

SEC. 6. All wagons shall have painted thereon, in plain, legible manner, the name of the dairy or owner thereof and the number of the wagon; and anyone selling or offering for wale milk, cream, or buttermilk without having a permit, as provided for herein, or selling or offering for sale milk, cream, or buttermilk, or other dairy proluct which is unwholesome or arlulterated, or in any way violating, as a whole or in part, the provisions of this ordinance within sairl city, shall be guilty of misdemeanor and subject the offenders to a fine of not less than $\$ 5$ nor more than $\$ 50$ for each and every offense.

This ordinance shall take effect from and after its passage.

Passed July 13, 1898.

\section{Erie, Pa.}

Rules and Regulations of the Board of Health Concerning the Mrle Supply.

SECTIOx 1. No person or persons shall sell milk or cream in the city of Erie without first, annually hefore the 1st day of July, registering with the board of health his or their name or names, together with the location of their route or place of business and the name of the owner of and the location of the dairy from which they obtain said milk or cream, and obtaining from the boarl a jermit to carry on such business, which fermit shall be issued without charge and shall be displayed in every store or wagon from which said milk or cream is sold.

SEc. 2. Every person or persons peddling milk or cream in the city of Erie shall have the wayn or other vehicle from which milk is sold inclosed and conspicuons. marker with his, her, or their names and the locality from which said milk or cream is obtained.

SEC. 3. No milk shall be sold, offered for sale, or distributed in the city of Erie unless the cow from which it is obtained have within one year been examined by a competent veterinarian and shown to the satisfaction of the board of health to be free from disease; but this dnew not necessarily mean that the tuberulin test must be employed.

SEc. 4. The quality of milk or cream offered for sale in this city shall be the same as is provided for by act of assembly, and skimmed milk shall not be sold except in the manner prescribed by such act.

SEC. 5. No milk or cream shall be sold by any person or persons in whose family or residence there is a rase of contagious or infectious disease or from any dairy in the vicinity of which there is such disease, except hy permission of and in the manner prescribed by the board.

SEC. 6. No milk shall be sold or exposed for sale in the city of Erie except milk sold from cows stabled under light, dry, and well-ventilaterl conditions, and in all other respects conforming to the reguirements set forth in the following rules:

Rule 1. Each cow shall have at least 3 feet in width of floor space when fastened in stanchions, and, in all cases where no adequate artificial means for ventilation are provided, each animal shall have an air space of at least 500 cubic feet.

Kule 2. All stables for shelter of said cattle shall be provided with a tight, dry floor. The mantre drop shall be water-tight, and if constructed of wond shall be asphalted, tarred, or otherwise made nonabsorbent.

finhe 3 . The walls and ceilings of said stables shall be whitewashed whenever it may be deemed necessary by the board of health.

linle f. Manure shall not be allowed to aceumulate in large quantities in stable yards nor near the buildings where the cattle are kept, and when stored temporarily in such places it shall be removerl at least once a month to a distance of at least 10 
feet from said stable. The stable yards shall be drained and kept in a clean, dry condition, and no accumulation of household garbage, vegretables, or nthe'r putrescible matter shall be allowed to remain or decay in said stable yards.

Rulr 5. Cattle shall at all times le kept in a clean conlition, and urlem shall be washed, hand-rubbed or wiped with a clean, damp cloth hefore each milking.

liule $;$. No milk shall be sold or offered for sale or distributed in the city of Erie olstained from any cow that has ealvecl within five days, or from a cow which will come in or calve within sixty days.

SEC. 7. No milk shall be sold or exposed for sale in the city of Erie excent milk obtained from cattle fed and watered under the following conditions: All food given to such cattle shall be goor and wholesome. Water supplied to cattle shall be pure and free from all contamination by stable or household drainage.

SEC. 8. All milkers and other attendants employerl in any dairy the milk from which is to be sold or offered for sale or delivered in the (ity of Erie shall be personally clean. Before milking or caring for the milk hands shall be wawherl and clothes changed or hrusherl, and no milk shall he delivered or sold or exposed for sale in said city produced from dairies wherein the foregoing regulations are not observed.

SEc. 9. To milk shall be kept for sale or distribution or handled, transferred from can, or stored in any stable or similar place, or in any room used wholly or in part for domestic or sleeping purposes.

SEC. 10. Milk shall be stored or recularly mixed, cooled, or poured from can to can only in a rom not directly connecter with a stable or stathles, providerl with a tight floor, and kept constantly neat and clean, the walls of the room being of such a nature as to allow easy and thorough cleaning.

SEC. 11. No animal, water-closet, or privy shall be in the aforesaid room or in any room connected directly therewith.

SEC. 12. Whenever milk is filtered or strained, cooled, or stored in a room, said room shall be such as is described in sections 9 and 10 .

Śx: 13. Nilk kept for sale in any store, shop, market, hakery, or other establishment thall he always kept in a covered cooler, box, or refrigerator, properly drained and cared for; and while therein shall be tightly corked or elosed, and only in such location and under such conditions as shall be approved by the hoard of health.

SEc: 14. All vehicles from which milk or cream is sold in this city shall, during the months of Jume, July, August, ant September, he expipperl with ice boxes, which shall be kept clean and which shall be of sufficient size.

SEc. 15. All cans, bottles, or vessels of any sort used in the sale, delivery, or distribution of milk to the consmer must be cleanerl and sterilized (hoiled, baked, sealded, or steamed) by the milk dealer before they are again used for the same purpose.

SEC. 16. To metallic or card ticket shall be need in connection with the sale or distribution of milk in the city of Erie, hut instead thereof a coupon ticket shall be employed, and such ticket shall he canceled and destroyed after heing once weel.

SEC. 17. Under no circumstances shall a milk dealer in the city of Erie, or his or her employee, take from a yuarantined house any money, can, buttle, etc, or enter such a house for any purpose whatever without written permission from the board of health.

\section{Montclair, N. J.}

An Ordinance Coxcernixg the Proptetion of Milk axd Regrlating Its Sile.

Be it ordained by the bourd of health of the tomen of ILontclair, in the county of Essed, as follous:

Sectron 1. Every person, corporation, or association of persons who now is or who hereafter shall he engaged in the sale or exposure for sale of milk within the town 
of Montclair, before selling or exposing the same for sale, shall furnish the board of health of the town of Montclair a true and complete statement as to the locality from which the milk so sold or exposed for sale is produced; also a full and complete list of the names and addresses of persons from whom the said milk is purchased, and the names and addresses of all persons to whom they are regularly selling or delivering milk within said town; said lists shall be furnisherl to the said board on the first days of January, April, July, and October of each calendar year, and at all other times when requested by the said board.

SEC. 2. No milk shall be sold or exposed for sale in the town of Montclair except milk from cows stabled under light, dry, and well-rentilated conditions, and in all other respects conforming to the requirements hereinafter set forth, viz:

(a) Each cow shall have at least 3 feet in width of floor space when fastened in stanchions, and in all cases where no adequate artificial means for ventilation are provided, each animal shall have an air space of at least 500 cubic feet.

(b) All stables for the shelter of said cattle shall be provided with a tight dry floor. The manure drop shall be water-tight, and if constructed of wood shall be asphalted, tarred, or otherwise made nonabsorbent.

(c) The walls and ceilings of said stables shall he whitewashed whenever it may be deemed necessary by this board of health.

(d) Manure shall not be allowed to accumulate in large quantities in stable yards nor near the buildings where the cattle are kept, and when stored temporarily in such places it shall be removerl at least once per month. The said stable yards shall be drained and kept in a clean dry condition, and no accumulation of household garbage, regetalle, or other putrescible matter shall be allowed to remain or decay in said stable yards.

(e) Cattle shall at all times be kept in a clean condition, and udders shall be washed, hand rubbel, or wiped with a clean damp cloth before each milking.

$(f)$ No milk shall be sold or offered for sale or distribution in the town of Montclair unless the cows from which it is obtained have within one year been examined by a competent veterinarian, and are free from diseases dangerous to the public health. But this shall not be construed as forbidding the sale or use of milk from cows not tested with tuberculin.

(g) No milk shall be sold or offered for sale or distributed in the town of Montclair obtained from any cow that has calved within ten days or from a cow which will come in or calve within sixty days.

Sec. 3. No milk shall be sold or exposed for sale in the town of Montclair except milk produced from cattle fed and watered under the following conditions: All food given to such cattle shall he fresh, sweet, and wholesome. The use of either distillery slops or fermented hrewers' grains is prohibited, and their presence on any dairy prenises will be considered sufficient cause for the excluwion of the milk from such dairy from sale or delivery in said town. Water supplied to cattle shall be pure and free from all contamination by stable or household drainage, and no well or spring in or adjoining any stable yard shall be used for watering said cattle.

SEC. 4. All milkers and other attendants employed in any dairy, the milk from which is to be sold or offeres for sale or delivered in said town, shall be personally clean. liefore entering upon their duties connected with the dairy, hands shall be washed, and clothes changed or brushed, and no milk shall be delivered or sold or exposed for sale in said town produced from dairies wherein the foregoing regulations are not enforced.

SEC, 5. Utensils used for the collection and transportation of milk shall, before heing used, be thoroughly washed with pure water and soda or soap, and then sterilized by boiling or steaming.

SEC: 15. Milk which is to le delivered or sold or offered for sale in said town shall, immediately upon being drawn from the cow, be removed from the stable to a room 
separate and apart from the said stable, and immediately cooled by submerging the vessel in which the milk is contained in cool water to a depth equal to that of the said milk in the vessel. The abover-mentioned room shall be properly ventilated and lighted and shall be used for no other purpose than that indicated above, and shall at all times be kept in a clean condition.

SEC. 7. The said milk shall the delivered in bottles unless permission for delivery in another manner shall he granted by said hoard. No tickets shall be used in connection with delivery of milk.

SEc. 8. If at any time any person on persons having any comnection with a dairy from which milk is delivered or sold or offered for sale in the town of Montelair, or any resident member of the fumily of any person so situated, shall be stricken with cholera, smallpox (including varioloid), diphtheria, membranous croup, yellow, typhus, typhoid, or searlet ferer, measles, or any other eommunicable disease that may hereafter be declared by this board to be dangerons to the public health, notice shall be given to said hoard immentiately hy the owner or owners of such dairy, and no milk produced from the dairy of any corporation, person, or association of persons failing to give the notice herẹin required shall hereafter he sold or exposed for sale or delivered in the town of Montelair until special permission therefor has been granted by said board.

SEC. 9. Any person, corporation, ol asseriation of persons violating any of the provisions of this ordinance shall, on conviction thereof, be liable to a penalty of not less than $\$ 10$ nor more than $\$ 100$.

Sec. 10. All ordinances or parts of ordinances inconsistent with the provisions of this ordinance are hereby repealed.

Passed March 24, 1898,

\section{Chicago, Ill.}

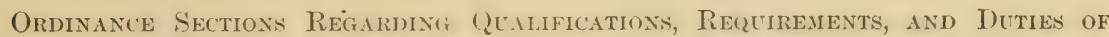
Milk Inspection Officials.

SEC. 934. There shall be appointed by the commissioner of health a superintendent and an assistant superintendent of the milk and food division. They shall be persons skilled in the science of analytical chemistry and bacteriology, and, before entering upon their duties, shall each execute a bond to the city of Chicago in the sum of $\$ 55,000$, with good and sufficient sureties to be approved by the mayor, conditioned for the faithful performance of the duties of their respective offices.

SEc. 936. There shall also be employed in the milk and food division of the department of health hereby created such assistants, employees, and inspectors as shall be deemed necessary by the commissioner of health, and they shall be under the direction of the superintendent and shall yerform such duties as are in this article provided and as the said superintendent may additionally direct. The inspectors employed under this article shall give a good and sufficient bond to the city of Chicago in the sum of $\$ 2,000$, to be approved by the mayor, and conditioned for the faithful performance of their duties.

\section{Ordinance Section Referring to Signs on Delivery Vehicles.}

SEc. 943. No milk or cream shall be sold, offered for sale, exposed for sale, exchanged, delivered, transported, conveyed, or carried on any wagon, carriage, or other vehicle unless the owner or owners thereof shall first obtain from the city clerk two painted netal plates s inches loner and + inches wide, on which shall be stamped the number corresponding to the license, and also the words "Chicago Milk Peddler," together with the year for which the license is issued, which plates the said licensed owner or owners shall cause to be se'urely fastened on the outside of each side of the box of his vehicle so licensed, or in a conspicuous place so that the same can be easily seen.

$25839-$ No. $46-03-12$ 


\section{Grand Rapids, Mich.}

\section{Ordinance Section Regarding Milk License Fees.}

SE: 2. Any person or persons desiring to sell, harter, or traftic in milk within the rity of Grand Rapids, on his or their application to the c1ty clerk of sairl city shall be licensed to do the same as hereinafter provided, and shall be granted a permit therefor upon the payment of the following license fee: For the selling of milk from wagons, \$5 per year; from milk earts propellerl by hami, \$I per year; from cans (arried by hand, 50 cents per year; for selling from dairies or creameries, \$5 per year; and for selling from private houses or restaurants and all other places, \$1 per year: Provided, howerer, That where more than one milk wagon is ownerl, operaterl, and controlled by the same person or firm, that a license fee of $\$ 2$ shall be charged for each arditional wagon, which said sum shall be paid to the city clerk and hy him paid to the city treasurer. Said license shall continue and be operative until the first MLnday in May nest ensuing the is:uance of the same, unless sooner revoked as hereinafter provided, and the license fees above provided shall be the same for a full year or for any part thereof: Provided, lowerer, That no fee shall be chargerl any farmer for such license or permit who does not rell any milk whatever except such as he produces from his own cows on his own farm.

\section{Houston, Tex.}

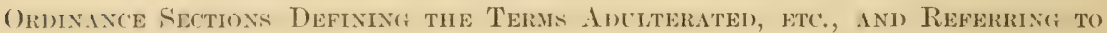
Milk Brought into the City.

SEC: 15. The terms adulterater, impure, unhealthy, and unwholesome, applied to milk or dairy products, and as used in this ordinance, mean-

(1) Milk containing less than 12 per centum of milk solids.

(2) Milk containing more than 88 per centum of water or fluids.

(3) Milk containing less than 3.2 per centum of fats.

(4) Nilk drawn from cows within fifteen days before or within five days after parturition.

(5) Milk drawn from cows fed on any unhealthy or unwholesome food.

(6) Milk drawn from cows kept in an mhealthy or msanitary condition, or from (ow affecterl with any form of disease, or from cows which are supplied with water which is impure or unwholesome.

(7) Milk from which any part of the eream has been removed.

(s) Milk which has been diluted with water or with any other fluid, or to which has been athed or into which has been introduced any foreign substance whatever.

(9) Milk drawn from cows, or by milkers that are themselves, in a condition of filth or uncleanliness.

(10) Any milk which is shown by analysis to contain any substance or substances of any dharacter whatsoever not natural or normal eonstituents of milk, or to have heen deprives either wholly or in part of any constituent naturally or normally contained in milk.

SEC: 2t. It whall be the duty of the owner or consignee of milk brought into the dity of IIonstum by land over any road or railroard leading into the city of Houston to canse the sante to be fendered and exposed for inspertion according to the require. ments of saicl health officer: Prorided, That said milk shall not be detained for inspection for a longer period than one hour. 


\section{Fall River, Mass.}

\section{Regulation 71, Referring to Skimimed Milk.}

SEc: 4. Skimmerl milk shall not be sold, exchangerl, or lelivererl within tho city of Fall River unless a special license therefor shall have heen first obtained from the board of health, which will be granted only on conclitions that the provisions of the? public statutes shall he olserved and that the words "Skimmerl Milk," the name of the licensee, and the number of the sperial license shall be painted on both sides of the wagon or other vehicle or can or veswel userl to conver or hold the milk, in letters and figures 2 inches in length and one-half inch in width and in some contrasting color to that of the wagon or can.

Fort Wayne, Ind.

\section{Ordinance Section Regarding Delivery of Skimmed Milk.}

Sro: 6. No skimmerl milk whall he sold, offered for sale, exchanged, delivered, transportecl, or carried in any watgon, carriage, or other vehicle unless the same is carried and containes in a can or vessel painted red, on which are conspicuously painter or printed the words "skimmerl Milk" in large, plain roman letters not less than 2 inches long.

\section{Milwaukee, Wis.}

\section{Ordinance Section Requiring Covering on Milk Delivery Vehicles.}

SEc. 4. No person or persons shall bring to or reliver milk in the city of Milwaukee for the purpose of retailing the same to consumers in the city of Milwakee in any open or uncovered wagon, cart, or converance of any kind; and all milk hereafter to be hronght to the eity of Milwanke to be retailed to consumers, or for that purpose to he deliverest in the city of Milwaukee, shall be hrought to sairl eity and delivered in cars, watems, or (arts s) ('omstructerl that the covering hereinbefore provided for shall not come in contact with the cans or vessels containing the milk, and shall protect such milk and the cans or vessels containing the same from the sun and rain, and, as far as practicable, from the dust and all the impurities of the air.

\section{Kansas City, Mo.}

\section{Ordinance Section Regarding Dairy Inspections.}

SEC. 1033. Examination of stables, lots, etc. It shall be the duty of the sanitary sergeant and the fwlicemen and eity chemist to at least onces every two months, and as much oftener as they think necessary and proper, inspect and examine all stables, lots, and pastures where cows are kept and fed whose milk or cream therefrom is sold in the eity; as also the fond such eows are ferl, and the health and condition of such cows, and make report thereof to the sanitary superintendent. If in their opinion any such cows are not fert on good and wholesome food or are kept in an unhealthy and barl condition, or such stahles and pasturesare not properly cleaned and kept so, then they shall so notify, verbally or in writing, the owner or keeper of such cows, stables, and pastures and also the persons who sell or offer for sale the milk or cream therefrom in the city. And if any such owner, keeper, or person shall not at once cease to milk any cow in an umhealthy and had condition, or shall refuse or neglect to at once proceed to clean such stables and pastures, the milk therefrom shall not be sold or offered for sale in the city until every objection thereto is abated and removed and kept so. Every person violating any provision in this section contained shall be deemerl guilty of a mistemeanor and on conviction shall be punished by a fine of not less than $\$ 50$ nor more than $\$ 500$. 


\section{Rochester, N. Y.}

Ordinance Section Regulating the Number of Cows to be Kept in the City.

Section 1. No person, firm, or corporation shall keep or allow to be kept in any building or on any grounds or premises of which such person, firm, or corporation shall he the owner, leswee, wr worupant, when such buildings, grounds, or premises are situater within the huilt-1up pertion sf the city of Rochester, more cows than 1 to a city lot of 33 feet by 150 feet, or space equal thereto, and no person, firm, or corporation shall keep or allow to be kept in any buikling or on any premises, of which such person, firm, or eorjuration shall be the owner, lessee, or ocenpant, where such builelings or premises are situated in the outlying portions of the eity, and where such premises are not suludivided into city lots or atually oceupied as such, more than 15 cows to each acre of land ownerl or oceupied by such person, firm, or corporation, without a permit from this department. Every permit isined under this ordinance shall be sulject to the rules, regulations, or ordinances of this department and may be revoked at pleasure of the department.

\section{San Francisco, Cal.}

\section{Ordinance Section Concerning Carrying Swill on Milk Defivery Vehicles.}

SEc. 9. It shall he unlawful for any person or persons, firm, or corporation to have or carry on any wagon or vehicle upon or from which milk or cream is being or is brought, arried, stored, deposited, sold, exchanged, delivered, or distributed or offered or expmesl for sale ur distribution as fond for any human heing, any swill, garbage, refuse, or any decaying or fermenting, putrefying, foul, unwholesome, noxious, or filthy matter, or any caus or receptacles containing any material or substance with which crem or milk might he diluted, adulterated, or rendered impure, unwholesome, or unhealthy.

\section{Denver, Colo.}

\section{Ordinance Section Regarding Notice of Use of Watered Mimk.}

SEC. 489. All pure milk shall be deemed to contain 12 per cent of milk solids, and any hotel, boarling house, or restaurant furnishing milk to their boarders, guests, or 'ustomers, or any of then, containing a le'ss yuantity of milk solids than 12 per cent, or a greater yuantity of water than 88 per cent, shall cause to be prosted and kept in a conspicuous place in the dining room where such milk is fumished for use a card with the words "Watered Milk" plainly printed thereon in large letters not less than : inches in length, so that the same may be plainly read from all parts of the room.

\section{Malden, Mass.}

\section{Ordinance Section Requiring the Publication of Names of Violators.}

SEc. 5. The inspector whall canse the name and place of business of every person comvicted of felling adultered milk or vinegar, or of having the same in his possession with intent to sell, to he published in two newspapers in the city or county. 


\section{APPENDIX U.}

The following is a copy of instructions sent out by an enterprising Boston milk contractor to the dairymen from whom his milk is obtained. Such an effort on the part of milk dealers to induce the observance of proper methods in the production and handling of milk is most commendable. Numerous dealers throughout the country have arlopted the same plan, using short original cireulars similar to this one. In some cases, upon special reyuest, the United states Departnent of Asrixulture has mailed appropriate Farmers' Bulletins to list of names of milk producers furnished for this purpose by those who are receiving and selling milk in cities.

\section{Suggestions and Rules for Dairymen Supplying Mrlk for Boston, Mass.}

Recent investigations of our milk supply have shown us the need of greater care on the part of the dairymen in the production of a cleaner and more sanitary milk. The following suggestions are those most necessary, and we earnestly hope will be carried out by you:

\section{A. WHITEWASHING COW STABLES OR "TIE-UPS."}

Whitewash acts as a mild antireptic and adils greatly to the general cleanliness and healthfulness of the stable. It should he applied both fall and spring, and it is thought by the associated hoards of health of llassachusetts that it should be required of all dairymen. It is gratifying to note that when whitewashing has been done in this way the farmers are very much pleased with the result.

\section{B. ENSILAGE.}

While ensilage is a very goor foor when fed in moderate quantities, there is a great tendency to feed too much of it and in that way injure the quality and flavor of the milk. It may be fert to the extent of one-half bushel per cow once a day directly after milking without injury to the milk.

Silos in the harn are manitary and fill the air with a very disagreeable odor. This is breathed by the cows, and is also absorbed by the milk, in that way injuring it permanently.

\section{MILKING AND CARE OF MILK.}

We call special attention to the fact that the cow's udder should be thoroughly cleanser by ruhbing with a damp eluth previons to milking, as any lonse dirt faliing into the pail causes the milk to spoil quickly, even though it is strained out immediately afterwards, as half of it dissolver in the milk, ant therefore can not be remover by straining. The milker's hands should also be retshed and dried just previous to milking, and should nerer be wet with the milk, as is the custom at present in some dairies. Milk will keep better if the first teaspoonful or two from each teat be milker on the floor or otherwise rejected, as this milk always contains the germs that cause quick souring. If we could inagine a portion of the milk removed directly from the cow's udder into an absolutely clean can, and covered with absolutely clean cotton batting one-fourth inch thick or more, this milk not having come in contact with the dust of the air or dairy utensils, it would keep in this way in perfect condition for weeks. Milk should be removed from the cow stable as soon as drawn, and should then be strained preferably through clean flannel and cooled as soon as possible to $40^{\circ} \mathrm{F}$. and held at that temperature, covered with a clean cloth until collected.

We again call attention to the fact that milk must be artificially cooled in winter 
as well as summer by placing the cans in cold water. Metal strainers soldered into the pail are objectionable, as it is almost impossible to keep them clean. Flannel for straining should be wrung out of hot water just before using.

\section{PAILS, CANS, AND STOPPLES.}

We have found that, while a dairy in general may be clean and eare taken with the milk, the latter sometimes fails to keep well. We have traced this trouble to pails, cans, and stopules. Milk pails should have all seams fillerl up flush with solder and should be thoroughly scalifed, waslierl in strong suds looth morning and night, and kept inverted until used for milking. (ans must he cleaned with briling sul sodu solution and rinsed with dean boiling water. Iinsing water from one can must not be used in rinsing another. If means are at hand they had also better be thoroughly steamed for ten minutes. This may he done by putting a quart of cleam water in the can and placing on the stove to boil. Do not attempt to wipe out the cans or pails, but let then dry in an inverted position. Wooden stopples should be hoiled in sal soda or solp powler solution for fifteen minntes and then rinsed thoroughly.

\section{E. INFECTIOUS DISEASES.}

Any disease of an infectious or contagions nature (typhoid fever, scarlet ferer, diphtheria, etc.), whether of the person handling the nilk or in his family, must be reported to ns at once, as several (ases have oc'urred in Somerville, Cambridge, and East Boston, where neglect to do this has resulted disastrously to the dealers.

\section{Keep this for future reference.}

\section{APPENDIX III.}

The following is a copy of an agreement made hetween the Medical Milk Commission of Escex County, N. J., and the party supplying milk according to its refuirements and receiving its indorsement (names of persons being here omitted):

Copy of the Agreement between the Medical Milk Commission of Essex
County, N. J., and C Caldwell, N. J.

[Dated May 19, 1893.]

The following agreement, made this 19th day of May, 1893, between ........... parties of the first part, and ............. New Jersey, party of the second part, wit asseth as follows: That the party of the second part doth herely lind hinself to a fulfilment of the provisions of this contract for and in consileration of the benefits hereinafter named by the parties of the first part.

Furthermore the following-named persons, ............ New Jersey, all acquaintances of the party of the seeond part, hereby aflix their signatures to this agreement, attest to the honor of the party of the second part, and hecome sureties for the execution of this agreement.

(1) The party of the seeond frart doth herehy arree to conduct surh parts of his dairy as may be hereinater namerl, collect, and handle its products in ronformity with the following code of repuirements, for and in consideration of the promised indorsement of the parties of the first part, as hereinafter inclieated. The milk thus produced shall he known ats certified milk, shall be designed especially for clinical purposes, and when at any time the demand shall he greater than the supply, and 
is required by a physician, either for infant feeding or the diet of the sick, it is hereby agreed that such shall be the preferred purchaser.

(2) The party of the second part further agrees to pay for chemical and bacteriological examinations of the aforesaid certified milk at such times as in the judgment of the parties of the first part is desirable.

(3) He also agrees to defray the cost of a bimonthly inspection of his dairy stock or oftener, if necessary, by a competent and approved veterinarian, all of which persons-namely, the chemist, the bacteriologist, the veterinary surgeon-shall be chosen by the parties of the first part, to whom they shall rencer their reports in writing.

(4) It is expressly understood and anreed that the party of the wecond part shall not pay more than the sum of $\$ 500$ in any one year for the services of chemist, bacteriologist, and veterinary surgeon, and the party of the first part shall linit the expense of such service to that amount. It is furthermore agreed that the party of the second part, on receipt of a certified copy of the reports of the experts, shall mail to the persons indicated by the parties of the first part, and not to others, a luplicate printed copy of the foresaid reports, bearing the signatures of the experts and the names of the physicians. The same to be issued at such intervals as in the julgment of the parties of the first part is desirable; also that the necessary expenditures for printing and circulation be met in the same way as herein provided for expert examinations.

\section{LOCATION OF LANDS.}

(5) It is hereby understood and agreed that the lands used by the owners, agents, or assigns of the dairy conducted by the party of the second part, and employert for pasturage, or any lands that may hereafter be acquired for such purposes, or such lands as may be used for the cultivation of hay or fodder, shall be subject to the approval of the parties of the first part.

\section{BUILDINGS,}

(6) It is also understood and agreed that the buildings, such as stables, creamery, dairy house, and spring house, shall be constructed after the most approverl style of architecture, in so far as construction may affect the health of the lairy stock or the character and conditions of the milk.

(7) That the buildings used for the housing of the animals shall he situatert on elevated ground and capable of being properly drained.

(8) Said buildings to be sheltered from cold winds, lighted, and ventilated according to approved hygienic methods. The builelings shall be construeted so as to favor the prompt and easy removal of waste products.

(9) The apartments used for the storage of either feed or fodder shatl be removert from possible contamination by stable waste or animal odors.

(10) All buildings shall, in addition to healthy location, approved construction, and proper ventilation, be kept free from animal or vegetable matter in a state or process of decomposition or decay, and always free from accumulations of dust or mold.

\section{THE WATER SUPPLY.}

(11) The dairy shall be supplied with an abundance of pure water.

(12) No water from shallow wells or springs holding surface drainage shall be used for watering stock, cooling milk, or cleaning vessels.

(13) Nor shall any well or spring be located within 300 feet of the stable.

\section{SURROUNDINGS,}

(14) It is further understood and agreed that the immediate surroundings of the buildings shall be kept in a condition of cleanliness and order. There shall not be 
allowed to accumulate in the vicinity any loose dirt, rublish, or decayed regetable or animal matter or animal waste.

(15) Nor shall there be within 300 yards of any building any constantly wet or marshy ground or stagnant pools of water.

(16) Nor shall there be kept within 300 yards of any building used for dairy purposes any fowl, hogs, horses, or other live stock.

(17) It is hereby understood and agreer that the following unhealthy conditions shall be a sufficient reason to exelude any animal from the herd used for any purpose in the aforesaid dairy: Any animal that is judged hy a competent observer to suffer from tuberculosis, even though the disease be localized in a part distant from the vital organs.

(18) Any animal with fever. Any animal suffering from septic absorption or other disease following or associated with parturition.

(19) Any animal suffering either from mammitis or mammary abscess.

(20) Any animal with persistent diarrhea or any other abnormal physical condition which could in any way be detrimental to the character of the milk.

(21) It is furthermore agreed that when an animal shall be found by a competent observer to be in a state of ill health, prejulicial either to the other animals in the herd or to human health, the same shall he removerl immediately, and if necessary shall be killed.

(22) It is also understood and agreed that the party of the second part shall exclude from the herd used for producing certified milk, immediately after discovery, any animal subject to the following comlitions: Any animal that was bred through consanguinity within a period of three generations.

(23) And from this time forth any animal of those bred hy the party of the second part, used for producing certified milk, that was not, as a heifer, kept sterile during its first twenty-seven months.

(24) Any phenomenal milker, except that glandular disease or tuberculosis has first been excluded by a competent observer.

(25) It is furthermore agreed that if at any time it is desired by the parties of the first part that a different breed of milch cows should be substituted for the one in use, in order that the standards of quality in the milk may be raised, the party of the second part will endeavor to carry the same into effect.

HOUSING AND CARE.

(26) It is furthermore agreed that the dairy stock employed in the production of certified milk shall be properly sheltered from the influence of weather and climate prejudicial to their health; also that the animals shall be kept clean, groomed every day, and treated kindly at all times.

(27) The waste products of the stable shall he removed so frequently, and the stable floor so thoroughly cleaned, that the same shall be as free as possible from animal odors.

(28) It is also agreed that no mileh cow shall be used for dairy purposes while in a state of excitement, either as a result, or during the period of, estrux, or which has been made nervous either by beating, whipping, kicking, prodding, or running.

FEEDING.

(29) It is hereby understood and agreed that the methods of feeding the cows furnishing the certified milk shall be subject to the approval of the parties of the first part. The feed and fodder shall consist only of nutritions and wholesome materials, such as grass, clover and timothy hay, whole grain, or the entire result of the grist. No materials shall be employerl which are or mat become injurious to the health of the animals. There shall not be ferl at any tine or in any quantity, either alone or mixed with other feed or fodder, hullw, screenings, wet or dry brewers' grains, oil 
cake, sour ensilage, the refuse from distilleries, glucose of starch factories, any waste by-product in the treatment of grain, low marsh grass, or any of the questionable or exhausted feeds or fodders employed either to increase the milking eapacity of the animal, or that will produce an impoverished milk, or that will impart to it umnatural odors or flavors. Nor shall the cows be allowed to eat green or worm-eaten fruit, poisonous weeds, or to drink poisonous or stagnant water.

COLLECTING AND HANDLING.

(30) It is furthermore understood and agreed that the cows from which is obtained certified milk shall be milked only in a clean building, and not in an illy ventilated stable containing foul odors and bad air.

(31) No animal furnishing certified milk shall be milked until the udder whall first have been cleaned in a manner approved by the parties of the first part.

(32) No person shall be allowed to draw the milk that has not, within fifteen minutes of the milking, first washed his or her hands, using soap and nail brush, and afterwards thoroughly rinsing the hands in clean water.

(33) The person or persons engaged in milking shall also be dresserl in clean orerclothes.

(34) No person shall be allowed to draw the milk who has been engaged with the care of horses in the same clothing or without first washing his hands.

(35) No milk shall be represented as certified milk that is not received from the udder into vessels, and from these into cooling cans, both of which are perfectly clean and dry, having been cleansed and heated at a temperature adequate to effect complete sterilization since the last milking and have been kept inverterl in a clean, dry, and odorless atmosphere.

(36) No milk shall be represented as certified milk that has not been passed through a sieve of wire or other cloth, either while milking or immediately thereafter, having not less than 100 meshes to the linear inch.

(37) No milk shall be represented as certified milk that does not consist of the entire contents of the udder at each milking, including the foremilk, middlings, and strippings.

(38) No milk shall be represented as certified milk that has been drawn from the animal at abnormal hours, such as midnight or noon, nor from any animal for a period of nine weeks before calving, or that has not been separated for nine days after parturition.

(39) No milk shall be represented as certified milk which has been exposed to the emanation or infection of any form of communicable disease, either in the person or persons handling the milk or by accidental contamination in eleaning milk containers, or by the association of any person engaged in handling the milk, with person or persons sick of contagious disease.

\section{PREPARATION FOR SHIPMENT.}

(40) It is hereby understood and agreed that all milk represented as certified milk shall receive every known detail of care that will promote its keeping qualities and favor its safe transportation.

(41) That the milk on being drawn from the cow shall be treated by ice or clean, cold water in motion, and proper aeration, in order, first, to remove its animal heat, and, second, to reduce its temperature to a point not above $50^{\circ}$ nor below $40^{\circ} \mathrm{F}$; said temperature to be acquired within forty-five minutes after milking and maintained within the above limits while held for shipment, during its transportation, and until it is delivered to the purchaser.

(42) That the cooling of the milk shall not be conducterl in the same huilding in which it is drawn, nor in an atmosphere containing dust or tainted with animal odors. 
(43) That all the foregoing provisions concerning the cleansing and condition of vessels or utensils shall be complied with in the said cooling process.

(4t) It is furthermore agreed that no milk shall be sepresented as certified milk that has been changed or reduced in any way by the aldition of water or any solid or liquid substance in or out of solution, or the subtraction or removal, in any manner, of any part thereof.

(45) It is herehy understond and agreed that all milk to be represented an certified milk shall be packed in flint glass quart jars immediately after it is cooled.

(46) Said jars to be of a pattern approved by the parties of the first part.

(47) It is furthermore agreed that the bottles or jary, before being used, shall be "leaned by hand, separately, with the aid of hot water, alkaline soaps, rotating brush and steam, and that they shall be rinsed in two separate baths of clean, hot water and then thoroughly drien and kept inverted until used, withont covers, in a clean dry atmosphere free from odors.

(48) It is agreed that the jars shall be filled ly a methox approved by the parties of the first part.

(49) That they shall be sealed, after all air has been excluded, by the most approved device for closing them.

(50) The buttles after heing filled shall be labeled across the cap, bearing the words "Certified milk," with the name of the dairyman, together with the date of milking.

(51) It is furthermore agreed that no milk shall be sold as certified milk that is more than three hours old when bottled nor more than twenty-four hours old when delivered.

TRANSPORTATION AND DELIVERY.

(52) It is hereby understood and agreed that the transportation and distribution of all milk represented as certified milk shall be conducted by the party of the second part, either in person or by persons employed by him.

(53) That in transit the milk shall not be exposerl to any of the foregoing prohibitory conditions.

(54) That it shall not be subjected to agitation.

(55) That it shall not be exposed to the heat of the sun.

(56) That the delivery wagons shall be so constructed that the required temperature of the milk may be maintained during transit.

(57) That before the wagons are filled for shipment the body, the trays, and compartments shall be flushed with boiling water.

(58) It is furthermore agreed that the distributing agents shall, during the transfer of the milk from the dairy to the purchaser, be subject to the following restrictions, namely, that they shall use no tobacco.

(59) That they shall take no intoxicating drinks.

(60) That they shall not collect the empty containers, nor receive money or milk "herks from houres in which an infections or contagious distase is known to exist.

(61) It is:alsu hereby agreed that the collection of empty hottles from places where infections or contagions disease is known to exist shall be made ly other persons than those employed to deliver the milk.

(62) That thene collections be made with wagons not employed in the distribution of the milk.

(6ii) That before these empty hottles shall be returned to the dairy they shall be carried to a separate building and first be suljected to the process of cleaning bottles indicated in a former clause of this contract.

(6it) It is heresty molerstood and anreed that if any further precautions or changes in methox calculated to improve the quality of milk or guard the sane from impurities or dangers is desired, that the party of the second part will cheerfully be gov- 
erned by such additional rules and regulations as may be laid down hy the parties of the first part.

(65) It is understood and agreed by the party of the second part, the sime binding the owners, agents, or assigns of the aforesaid dairy, that the proluct known as certified milk shall be under the following restrictions in its sale, namely: That until the amount required within the boundaries of Essex County shall first he supplied, it shall not be sold beyond these limits, except that the parties of the first part shall give their consent.

(66) It is furthermore agreed by the party of the second part, the same loinding the owners, agents, or assigns of the aforesaid dairy, that in the event of a failure to comply with any or all of the requirements of the foregoing contract, the party of the first part shall reserve the right to withdraw from the contract and jublish the fact in such manner as they deem best.

(67) Finally, it is understool and agreed that nothing in this contract shall prevent the abrogation of any of the provisions of the same by the parties of the first part, provided that it shall he done for the purpose of sulstituting other provisions designed to promote the objects of their organization.

(68) It is further understoxl and agreed by and between the frarties hereto that the party of the second part shall he at liberty to cancel this agreenent by giving two months' notice in writing of his rlesire to do so, in case of inability for any reason to comply with the terms of the same.

In witness whereof, the said parties have heremto set their hamds the day and year first above written.

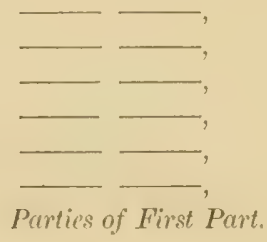

Party of Second Part.

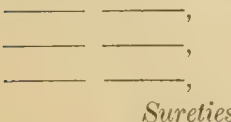

At frequent intervals reports upon the conditions of the dairy and quality of the milk are rendered to the commission hy experts appointed for this purpose.

\section{APPENDIX IV.}

Following are copies of blank forms used in the supervision of market milk. For brief discussion of them see page 22 . A suitable space for the answer to each question is always provided, but in the longer forms the spaces are here shortened. 


\section{Form for application for milk license, Cambridge, Mass.}

City of Cambridge. Office of Inspector of Milk, City ilati.

Application for Milk License.

Date of application, ....... Present license No.

Name (if a firm, give firm name and also individual members' names in full):

Address :

No. of teams: Driver.

Residence.

1.

2.

3.

4.

5.

No. of cans of milk sold per day in Cambridge $\left\{\begin{array}{l}\text { Wholesale, ....... } \\ \text { Retail, ....... }\end{array}\right.$

Cream, quarts, ........ Skimmed milk, cans, .......

Source of milk (if from a contractor, give name of contractor; if from farms, give the town or towns where they are located; if from your own furn, give location of dairy and number of cows kept.)

Signature of applieant:

Form for application for milk license, Chicago, Ill.

Department of Health, City of Chicago. Difision of Milk Inspection.

Application for Milik License.

STORE LICENSE.

Name, ...... Location of business place or places, ...... Number of wagons, ..... Number of cows,..... Description of wagon or wagons (number, inscription, and color), ......

Your attention is called to the section of the milk ordinance relating to applications for milk licenses:

"SEC. 17. (License, issue of, application for.) Licenses, shall be issued in the names of the applicants therefor. Before the iswuance of the license every vendor of milk or cream shall make written application therefor on a printed form provided for that purpose, on which shall be stated:

"First. The name, residence, and location of the business place or places of the applicant.

"Second. The number of cows, if any, owned or controlled by the applicant.

"Third. The number and deseription of each and every wagon, carriage, or other vehicle used in the milk or cream business.

"Fourth. If, after the issuance and delivery of the license, any change he marle in the location of the place of business of such licensere, notice thereof must forthwith be given to the chief of milk inspection."

\section{To tire City Coliector:}

Nignerl:

The above application is approved and issue of license is herehy recommented.

License No...... Commissioner of Health.

Note.-The form used in applying for wagon license is the same in all respects, except it is a different color. 


\section{Form for application for milk license, Erie, $\mathbf{P a .}$}

Application for Milik License.

\section{Board of Health,} Erie, $P(1, \ldots . . . . .$.

I hereby make application for permission to sell milk in the city of Frie, from a ......, subject to your rules and regulations.

The dairies from which I obtain milk are located in ...... township, and are owned by . ...... There are no injured or diseased cattle in the herd or herds from which said milk is olstainerl; and there are no cases of typhoid ferer, consumption, diphtheria, searlatina, wr other contagious or infectlous diseases in my house, family, or among my employees or in the home, family, or among the employees of the owner of said dairy or clairies. In case of the appearance of any of the above-mentioned diseases I will immerliately make report thereof to the hoard of health.

Name:

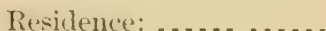

Sworn and subscribed before me this ...... day of . ....., .....

. . . . . Sictertury Bourd of Health.

\section{Form for application for inspection, Meadville, Pa.}

Application for Inspection.

To

Tnspector of Food and Milk for the City of Meadville, Pa.:

Desiring to sell milk to the citizens of Meatrille, Pa., I make applieation to you to insperet my cattle and appointments for the supply of milk, under the rules and regulations of the boaml of health of said city, and I herely agree to observe strictly the following renulations regarding the milk which I supply to all my customers:

No milk shall be delivered-

(1) From cows that are unhealthy; from cows receiving any kind of medicine; from enws with inflaned udler or with uditer or any part thereof in an abnormal condition from any cause; from cows while in heat, unless such cows are kept from the rest of the herd during that time; from cows within 60 days before or six days after calving.

(2) From cows that are ferl partially or wholly on turnips, cabbage, ensilage, brewery, or distillery malt, rancid foods, or any other kind of food that would deteriorate or taint the yuality of the milk; from cows supplied with bat or impture drinking water.

(3) Nor shall any milk be delivered which has been drawn from the cow more than fifteen hours, nor from which any part of the cream has been removed, or from which strippings have heen kept back; nor will I sell during the summer any milk which was milket prior to 5 o'clock in the afternoon, nor milk which differs in any way from fresh, sound, pure, unadulterated cow's milk.

(4) I also agree that I will not fumish milk from any cows unless they have been inspected by milk inspectur for Meatrille board of health, and that my cows are to be milked in the cleant possible manner, withont moistening the teats; that milkers' hands shall be kept clean, and udders wiped with a clean damp eloth just before milking. I alwo ayree that all ny milkers shall wear a clean outer garment, to be used for no other purpose than for milking, and to be worn at each milking.

I agree to remore eatch cow's milk immediately after milking from the stable and to strain, cool, and aerate all of my milk until the temperature is reduced to $58^{\circ} \mathrm{F}$. in less than 45 minutes by placing the cans in a tub or vat, said tub or vat to hold 
three times as much water as the quantity of milk to be cooled, water in said tub or vat to be renewed daily.

I agree that special care shall be taken to remove daily all manure from the stables and anything of a foul or unclean nature, and to keep my stables clean, and whitewash the same each fall and spring every year.

I agree to keep ny cow yards reasonably free from mud or manure, and that I will not stack manure against my cow stables at any time.

I agree should any member of my family or employee become sick with any contagions disease that I will immediately notify the health officer and milk inspector of the Meadville board of health.

I agree to notify the milk inspector of any dwelling placarded for contagious disease, if said building is occupied by persons to whom I sell milk.

I also agree that the Meadville board of health, or any member thereof, or any person in the employ of said board, shall have the right to visit at any time my premines for the purpose of inspecting the cows, stables, milk house, food and water supply, and take samples of milk at any time from my dairy or on my route, in order to see that the foregoing rules are observed.

Ilaving real the above, I hereby agree to all the provisions contained therein and herehy agree that the Mearlville board of health may revoke my permit for noncompliance of said provisions at any time.

Signed:.......... ,

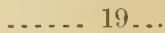

\section{Form for application for milk license, Iowa.}

\section{City Milk Dealer's Report for Year Ending July 4, 1901.}

The law refuires that the permit be taken out before selling milk or cream. Any one selling milk withont having the permit is subject to the penalties named in the law. See below. This department will not hold itself under obligations to send further notice, and action will begun at the discretion of the dairy commissioner after the 4 th day of July, 1901, without further notice.

REAI) THE LAW.

SEc: 2525. Permit.-Any person or corporation who shall sell milk or cream from a wagon, depot, or store, or sell or deliver milk or crean to a hotel or restaurant or hoarding house, or any public place in any such city, shall be considered a city milk dealer. No such city milk dealer shall sell milk or cream from a wagon, depot, or store in any such city without a written permit from the commissioner for each wagom, depot, or store operated by him, for which he shall pay annually one dollar. All permits shall expire on the fourth day of July of each year, and no permits shall be issued for less than one dollar.

SEc. 25:-7. Penallies. - Whoever shall violate any provisions of this chapter shall be punished by a fine not exceeding five hundred dollars, or by imprisonment in the county jail not exceeding six months, or by both such fine and imprisonment, at the discretion of the court.

Name of dealer, firm, or company. (Please write all names and addresses plainly.) ......

City, ...... Street and number or P. O. box, ......

Do you sell whole milk? ...... Cream? ...... Skimmed milk? ......

How many months in the year do you conduct your business? ......

How many families, hotels, etc., do you supply? Private families, ...... Hotels, ..... Restaurants and lunch counters, ...... Boarding houses, ...... Ice-cream parlors and soda fountains, ....... 
State average number of gallons milk sold per month. ...... gallons.

State average number of gallons cream sold per month. ...... gallons.

State average number of gallons skimmer nilk sold per month. ...... gallons.

Is the milk and cream which you sell delivered to you? ...... If so, give name of person from whom you receive the same. ...... Is he a retailer of milk? .....

If you produce your own milk, state average number of cows in your herd. .....

State number of Jerseys. . ...... Grade Jerseys. . . . . . .

Number of Holsteins. ...... Grade Holsteins. ......

Number of Shorthorns. ...... Grade Shorthorns. ......

Number of Red Polled. . ...... Grade Red Polled. ......

Number of cows of other breeds or common stock. ......

What is the number of persons employed in your dairy business? ......

Do you wholesale milk to others? ...... If so, give the names of all to whom you sell milk or cream. ......

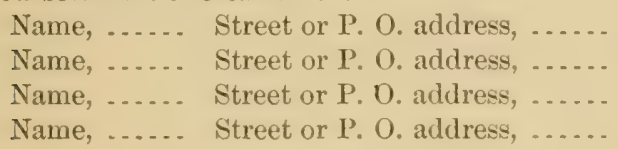

APPLICATION FOR PERMIT.

Note. - When more than one wagom, repot, or store is operated, each should be numbered from one up to the number used.

........... 1901.

......, State Dairy Commissioner, Des Moines, Iowa:

..... hereby make application for ..... permit.. to sell milk in the city of ......, Iowa, for the year ending July 4, 1902. The following is a memoranda of each depot, store, or wagon under the management of the undersigned:

...... street. Wagon No. 2 starts from No . . . . . . street. Store or shop located at No ...... street. Wagon No. 3 starts from No ..... street. Wagon No. 1 starts from No ..... street. Wagon No. 4 starts from No ...... street.

Herewith find inclosed a draft, postal money order, or express money order to the amount of ..... dollors, for which please forward the number of permits enumerated above.

Signature:

Note.-In all cases $\$ 1$ must accompany the application. This department will not assume or recognize any lows axising from remittances by cash or pustage stamps.

All permits expire July 4 of each year.

Form to accompany application for milk license, Haverhill, Mass.

City of Hayerhill, Office of Inspector of Milk.

To THE Milk DealeRs of Havermill:

Owing to the insanitary manner in which a great number of milk cows are kept and cared for, and the unwholesome and areless methols of some probucers in obtaining and caring for milk at the time of milking and immediately thereafter, it becomes the duty of the inspector of milk to hereby notify you that all applicants for milk licenses to sell milk within the limits of the city of Haverhill for the year beginning May 1, 1900, are repuested to have the producer from whom such milk is obtained fill out the following form:

Producer's name..... . To what dealer do you sell your milk?...... How many cows in your possession?..... I Iare they been inspected within the last six months? 
..... By whom?..... Give length of stable..... Give width of stable...... Give width from manger or "tie ups" to wall behind animals...... Give average height from floor to ceiling...... Number of windows facing north not obstructed ..... Size..... Number of windows facing south not obstructed...... Size ..... Number of windows facing east not obstructed..... Size..... Number of windows facing west not obstructed..... Size..... Is the stable open or (dised in front of animals?...... Is the stable well lighted?...... Is the stable in basement or cellar?...... When is the stable cleaned?..... What is done with the manure?..... Is there a cellar under barn?..... Is the cellar open or closed? ..... . Does the air in the stable seem good? or is it heavy or bad smelling?..... How is the stock watered?...... If from well, give its location in regard to barn ("ellar, manure yard, sink drain, privy vault, cesspool, or other source of possible contamination...... When is stock cleaned?...... What do you bed your milk cows on?...... Are they milked by clean and healthy attendants?...... Do you mix the milk from all your cows?. ..... How and where do you mix your milk?...... Are any of your cows sick or diseased at the present time? .....

\section{Form for application to sell milk, New York City, N. Y.}

$38 \mathrm{G}, 1899$.

No.....

Borovgit of Manhattan.

Application (STORe) No. 1.

To the Bodri) (fF Healti of the Departafent of Health of the City of New York:

The undersigned herely applies for a permit to sell fresh and condensed milk in the city of New York, and makes the following statement in accordance with the laws, rules, and regulations of the board of health of the department of health of the city of New York:

FRESH MILK.

Name, ...... Business, ...... Location, ...... Quarts sold per day...... From whom purchased $a \ldots$. Location, ...... Time of delivery, ..... Marks on can, ......

CONDENSED MILK.

From whom purchased, "..... Location, ..... Quarts sold per day, ..... Time of delivery, ...... Where is fresh or condensed milk kept during sale?...... How is ice box connected with sewer?..... Where located, ......

Signed, .............

Address, ..............

Dated New York ........, 189..

This form to accompany preceding blank when applicable, New York City, N. Y.

FORM $123 \mathrm{C}-1896$.

No.....

SPecial Information Brank No. 3.

Iilk purchased or ohtained from farmer, milk agent, creamery, condensary, or from farm belonging to applicant.

Name of milk agent, ...... Residence, ...... Name of farmer, owner of creamery or condensary, ...... Town, ..... County, ..... State,..... Shipping

"If purchaserl or obtained from farmer, milk agent, creamery, condensary, or from farm belonging to applicant, fill in special information blank No. 3 . 
station, ...... Railroad, ...... County, ...... State, ...... No. of cans per day, ...... Marks on cans, ...... Time shipped,..... What milking shipped, ..... Time in transit, ..... No. No uf enws, ..... Breerl, ...... ('ondition, ...... Food, ...... Housing, ...... If in the city, ...... Permit No..... Water supply for cows and where obtained, .....

iinnerl, ...........

Ardiresis, ...........

Dated New York, ......., 189..

Form for application to bring milk into the District of Columbia.

Health Departient, District of Columbia, Washington, .............

SII: The ate to regulate the wale of milk in the District of Columbia provides that "mo person shall hring or send into the Inistriet of (chlumbia for sale any milk without a permit of to do from the health officer of said I istrict, and that such permits shall be issued subject to the following conditions:

That none hut pure and unatulterated milk shall lee, with knowledgee of its impurity, brought into said District.

That in the mamagement of the dairy farm mun which the milk is problued, or of the dairy at which the milk is collecteil and stored prior to shipment, the applicant shall be governed by the remulations of the health oflice of the I)istrict of Columbia,

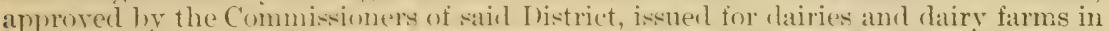
sairl District, when sairl reeglations der not conflict with the latw of the state in which said dairy or dairy farm is located.

The saicl dairy or dairy farm may be inspecterl at any tine without notice by the health officer of the District of ('olumh ia or his duly appointerl representatives.

The veterinarian's certificate must be from one who has regularly graduated from a veterinary medical college, or who practices under a license from a State examining board. If mable to secure the services of such, so state on your applicution blank, and all other condi-

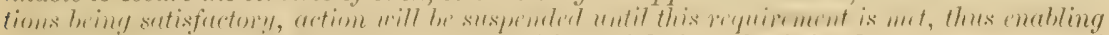
you to send or bring milk into the District vithout violation of existing luxt.

If you desire to bring or send milk into the District of Columbia for sale, please fill ont and sign the application helow and forward it to the health officer without delay. Permits will he issuerl, withont cost, as son as posihile after the receipt of the application.

The aphlication for and aceptance of a permit necessarily carries with it the acceptance of the conditions specified above. A copy of the regulations referred to is inclosed herewith.

Respectfully,

WM. C. WUODWARD, M. D.,

Health Officer.

$[1, \ldots . .$.

Applichtion for Permit to Seni) or Bring Milk into the District of Columbia.

To the Health Officer, D. C.

SIR: In compliance with "An act to regulate the sale of milk in the District of columbia, and for other purpuses," I herehy nake application for a permit to send or bring milk into sail District, from the premises describerl below, located ...... Number of shipments per day, ...... Total number of gallons, ...... . whole milk, skimmed milk, cream. Shipped in wagon, ......; boat, .....; B. and $O . R$. R., ..... ; B. and P. R. R, ..... Time of delivery, ..... Place of delivery, ..... Consigned to .......

$$
25839-N o \cdot 46-03-13
$$


Diuscription of Premises.

BUILDING.

Brick,

Frame, stories high. Condition, Is any part of it used for any other than dairy purposes? ...... If so, specify, in the space for remarks, what parts of it are so used, and the purposes for which used.

Room for cattle. -Size, ...... long, ...... wide, ...... high. Floor, kind, ......; condition, ...... Is it properly sloped and guttered? ...... What disposition is made of the drainage? ...... Ventilation and lighting. How accomplished? ...... Windows. How many? ...... Location, ...... Size, ..... A windows glazed? ...... Ventilators. How many? ...... Kind, ...... Location, ...... Size, ...... Doors. How many? ...... Location, ...... Stalls. Where located? ...... How many? ...... Size of each? ...... wide, ...... long, ...... wide, ...... long. Are animals of any kind other than cattle kept in this room? ...... If so, specify how many and what kind. ......

Feeding troughs or boxes.-How many? ...... Kind, ...... Location, ...... Condition, .......

Water troughs.-How many? ...... Kind, ...... Location, ...... Condition, ..... If water troughs are not used, how are cattle watered? ......

Source of water supply.-If from well, state location ...... Approximate depth ...... feet, and construction ...... Location of well with reference to nearest privy. State distance and slope of ground ...... Location of well with reference to place where dung is deposited. State distance and slope of ground ...... Has water any perceptible odor, color, or taste? ...... If so, describe ......

Receptacles for dung and other refuse.-How many? ...... Kind ...... Location ...... Condition .......

Receptacles for milk.-How many? ...... Kind ...... Condition ...... What provision is made for cleaning? ...... Is milk cooled immediately after milking? ..... If so, how? ......

BARNYARD,

Size ...... long ...... wide ...... Is it properly graded? ...... and drained? ...... Is it paved? ...... What disposition is made of the drainage? ...... What is its condition as to cleanliness, at time of inspection? ......

\section{PASTURE.}

Size of ..... Condition of ...... Is it supplied with drinking water for the cattle? ...... If so, from what source? ......

CATTLE.

How many milch cows are usually kept? ...... How many other cattle, if any, are kept in the same stable? ...... Kind of milch cows used ...... Condition of cows at time of inspection. General condition ...... Cleanliness, ete ...... Character of feed ......

PRIVY ACCOMMODATIONS.

How is human excreta from the premises disposed of? ...... Location of privy, if any? ...... Construction of privy ...... 
The above covers three pages of a four-page circular. On the last page provision is made for the certificate of the reterinarian who has examinerl the herd and premises described; also memorazda to appear on the outside fold when ready for filing. It is as follows:

To the Health Officer, D. C.

SIn: I have carefully examined the cattle upon the premises ahove referred to, and their condition is as follows:

Signature:..........

Address:

Personally appeared before me this

189. , the subseriber, who, being duly sworn, deposes and says that he is a veterinary surgeon, practicing in accordance with the laws of the State in which he resides, and that he has personally examined the cattle referred to in the above statement and knows them to be the same as are referrerl to in the application to which the certificate is appended, and that their condition is correctly described without evasion or concealment.

Signature: ............

Ailitres: $\quad$............

Forms entaining all the alowe puestions under "Deseription of premises" are used by inspectors for reporting conditions found on their visits.

Form for application to sell milk, Boston, Mass.

Application for License to Sell Milk in the City of Boston during the Year Ending May 31, 1900.

Name of applicant, ...... Residence (street and number, town), ...... Place of business, ...... Number of wagons used in delivery of milk, ..... Number of drivers employed,

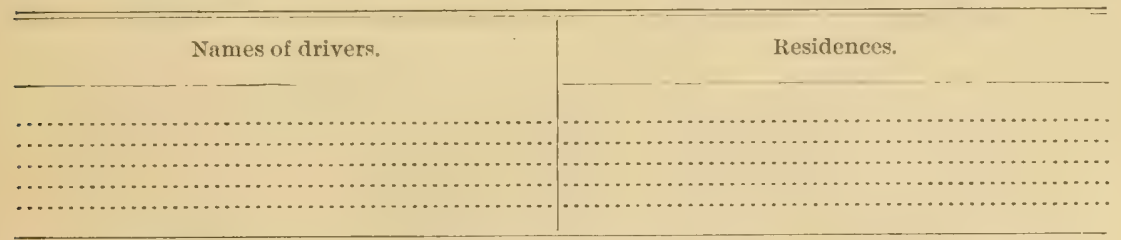

Section supplied,

Amount of milk raised (quarts),

Number of cows kept, ...... (If any, fill out Form 3.) Amount of milk bought (quarts), ..... Of whom bought, ...... Where delivered by him, ...... Hour delivered, ....... a.m.; ...... p. m. Where stored and handled after delivery, ...... Whether mixed, handled, or stored where cows, horses, or other animals are kept, or where manure is stored, ...... Whether mixed, handled, or stored in rooms used for domestic purposes or sleeping rooms, ..... Location of milk room, ...... How drained, . . ... Whether walls are tight and easily cleaned, ...... Whether floor is tight and easily cleanerl, ...... Thether appliances are at hand for washing or sterilizing all utensils, ...... Whether any water-closet, urinal, or privy is located in the room, ...... Whether ice-box or refrigerator drained, and how,......

The above is a correct statement.

Wituess ......

Signature ............

Boston ......

License issued ......

Number of license 
Form for report upon dairy and herd inspection in North Dakota.

State of NoRth Dakota,

Office of Assistant Dairy Commissioner, Official Dairy and Herd Inspection,

Date, ......

City, ....... County, ...... Location, ...... Dairyman's name,..... I'. O. address, ...... No cows, ...... No. license, ....... Condition of cows (flesh), ..... Condition of cows, sanitary, ...... Condition of cows, apparent health, ..... Condition of barn, ...... Ventilation of barr, ...... Condition of utensils, ...... Kind of feed, ...... Water, ...... Where milk is kept, ..... Method of delivery, ........ Breed of cows, ........ Tuberculin test, Remarks,

Inspector.

\section{Form for report upon inspection of dairies, Erie, Pa.}

INSPECTION OF DAIRT.

Date, ..... Owner, ...... Residence, ...... Name of tenant, ...... Location of dairy, ...... No. of wagons, ...... Section of eity supplied, ..... Examination of cows: No. clean, ...... No. unclean, ...... No. healthy, ...... No. unhealthy, ...... No. suspected, ...... How fed in summer, ...... How fed in winter, ..... How watered, ...... Disposition of at night, ..... Stable: Material, ...... size, . . . . . how ventilated, ...... drainage, ...... No. of stalls, ..... Disposition of manure: Temporary, ...... permanent, ...... Water supply: Source, ...... distance from house, ..... from stable, ...... from privy, ...... from manure pile, ...... Milkers: No.male, ...... No. female, ...... No. healthy, ...... No. unhealthy, ...... Sickness in family, ..... in neighborhood Milk: Where stored, ..... how hong, ..... in what, ...... how cooled, Remarks:

Inspectur.

Form for report upon inspection for dairies, Salt Lake City, Utah.

Datry AND Milk Report.

....., 189.. 1. Name of dairy, 4. Name of proprietor, ..... 5. Post-office address, ...... 6. Date of inspection,
$\ldots . .$. . Average quantity of milk sold per day, ..... 8. No. wagons, .....

3. Location, ......

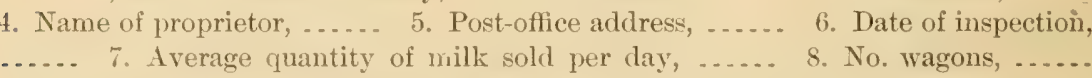
4. Name of proprietor, ..... 5. Post-office address, .....
..... 6. . . Date of inspection, 9. No. cows, ..... 10. Grade of cows, ..... 11. No. acres of pasturage, ...... 12. Condition of cows, ...... 13. Condition of milking utensils and how cleaned, ..... 14. General appearance of milkers and other employes, ..... 15. Water supply, ..... 16. General sanitary condition,..... 17. Quantity and kinds of food: Hay -alfalfa, ...... pounds per day; mixed, ...... pounds per day. Bran, ..... pounds per day. Shorts, ...... pounds per day, Malts, ...... pounds per day. Grains, ..... pounds per day. Beet pulp, ..... pounds per day. 18. Qnality of milk, ...... 19. Remarks......

ICat and Will: Thsprector.

Form for reporting conditions of dairies, Boston, Mass.

Statement of conditions under which cows are kept, and milk therefrom stored, on the premises of ......, at (town) ......., (State) ......, said milk being supplied by ...... to ....... for sale in the eity of Boston, Mass. 
NTABLF

Number of cows kept, ...... ; approximate air space per cow, ...... Whether cow stable is well lighted, ...... Whether cow stable is well ventilated,..... How drained, ...... Condition of floor, ...... Whether manure is stored in cellar, ...... If not in cellar, where stored? ......

\section{MILK ROOM.}

Whether milk is cooled, mixed, or stored where cows or other animals are kept, or where manure is stored, ...... Whether cooled, mixed, or stored in rooms used for domestic purposes or sleeping rooms, ...... Location of milk room, ...... Whether walls are tight and easily cleaned, ...... Whether floor is tight and easily cleaned, ...... Whether appliances are at hand for washing or sterilizing all utensils, ...... Whether any water-closet, urinal, or privy is located in the room, ......

\section{CONDITION OF COWS.}

Date of last examination of cows, ...... By whom examined, ...... Number examined, ...... Whether any cows were found to be diseased, ...... Whether any cows have been added since; and if so, how many? ...... Whether added cows were examined; and if so, when and by whom? ..... .

\section{SHIPMENT OF MILK.}

Amount of milk shipper, ...... To whom shipped, ...... How shipped, ...... Marks on cans, ......

The above is a correct statement.

Signature, ............

Arlilies, ...........

Witness, .....

Date',.....

Form for reporting conditions at dairies and methods of handling milk in New Jersey.

ReCord of DaIRY INSPECTION.

Board of Health of the State of New Jersey,

1. Name of dairyman, ...... (tenant-owner).

2. Post-office, township, county, ......

3. Location of dairy, ......

STABLE.

4. Size of stable, ......

5. Cubic feet per cow, ......

6. Stable well lighted? ......

7. Material, construction, and drainage of floor, ......

8. Method and frequency of cleaning, ......

9. Was stable clean at time of inspeetion? ...... .

10. Are side walls, ceilings, and ledges kept free from cobwebs and dust? ......

11. Ever lime washed?

\section{WATER SUPPLY.}

12. Sources of water supply for watering stock, ......

13. Sources of water supply for washing cans, bottles, and utensils, ......

14. Distance of well or spring from stable, ...... 
15. Distance from manure pile, ......

16. Distance from privy vault,

17. Distance from other sources of contamination, ......

18. Is well apparently liable to contamination?

19. Was sample of water taken for analysis?

20. Marks, ......

CATTLE.

21. Number of cows, .......

22. Breed, .......

23. State of health, ......

24. Ever examined?

25. By whom?

26. Date of last examination, ......

27. Were cows in a cleanly condition at time of inspection? ......

28. Amount, kind, and quality of feed used, ......

29. Cows pastured? ......

MANURE.

30. How and where stored? ......

31. How frequently removed? ......

32. Quantity of manure at time of this inspection,

UTENSIIS.

33. How washed and dried?

34. Where are the utensils washed?

35. Any appliance for sterilizing cans, pails, and dippers? ......

36. Bottles-how washed and dried? ......

COLLECTION OF MIJK.

37. Quantity of milk produced daily, ......

38. Are milkers' hands washed before milking? ......

39. Are clean garments put on? .......

40. Udders of cows cleaned? ...... 41. How? ......

42. When pail is full of milk what is done with it? ......

43. Where does the can stand? ......

44. Is can kept covered? .......

45. Is milk cooled? ....... 46. How? ......

47. How long after milking? ......

48. To what temperature? -.....

49. Is milk bottled?

50. How long after cooling? ......

51. Where is milk bottled?

52. Where is milk stored? .......

53. How long is milk stored before being shipped? ......

54 . Source of ice supply,

55. If shipped, to whom, and where?

DISTRIBUTION.

56. Temperature of milk when delivered to customers, ......

57. Quarts sold from cans, ......

58. Quarts sold in bottles, .......

59. Ever run short? .......

60. If so, where is supply obtained? ......

61. How many persons handle the milk? ......

62. All in good health?

63. Date of last sickness among persons on dairy premises,

64. Diseases,

65. Remarks 


\section{Form for notice which must be sent to the inspector when cows are added} to a dairy herd, Kansas City, Kans.

To MrLK Producers:

Tnder the milk inspection ordinance it is made unlaw ful for anyone, after his dairy is inspected, to add any cows to his dairy, unless, within twenty-fours hours, he shall notify the inspector of such addition. In case you shall add any cows to your inspected dairy, please fill out the following statement and promptly send it to the inspector of licenses, weights, and measures, City Hall, Kansas City, Kans.:

To the Inspector of Licenses, Weights, And Measures:

I have this day added ...... cows to my dairy kept at ......., and I hereby declare the cows so added to said dairy are each and all in a healthy condition.

Dairy Inspection No......

Sign here ......

\section{Form for placing in quarantine cows suspected of having tuberculosis, North Attleboro, Mass.}

Form No. 3 n. -95.

Order of Quarantine.

[Section 7, Chapter 491, Acts of 1891.]

ORIGINAI,

[To be delivered to owner or person in eharge.]

To be used only for cows in milk suspected of being tuberculons.

To

Town or eity of $\ldots . . ., \ldots, \ldots, 189$.

......, owner (or person in charge):

You are herely notified that, by virtne of the powers and authority in me vested by law, I have caused to be isolated and placed in quarantine in ...... upon your premises, to wit, ...... the milch cow deseribed as follows: ...... under suspicion of having the disease known as tubereulosis, a contagious disease under the law.

Tou and all other persons whom it may concern are hereby forbiden to remove the same from saicl place of quarantine for the purpose of slaughter or for any other purpose whatsoever, or otherwise to break said quarantine, until the further order of the local hoard of health, the cattle commission, or some one of its members.

You are notified that until this quarantine is removed said cow is deemed to be diseaverl. You are warned of the danger of using the milk therefrom, and are forbidden to sell or otherwise dispose of it in any market.

The Commonwealth will pay the actual expense of this quarantine which may be incurred after the tenth day, upon your returning to the hoard of cattle commissioners a satisfactory certificate of such expense.

[Use a separate order for each animal.]

......, Inspector.

REA1) THE O'THER SIIE.

(NoTE.-Upon the back of the form is printed in full the section of the law referred to above, relating to cattle quarantine.) 


\section{Form for milk-store permit, New York City, N. Y:}

DEPARTMENT OF IEALTh, UTT OF NET YoRK, Nell Jork, ......, 189..

Permit No.

is hereby authorized to sell milk, fresh and condensed, at. No. . . . . ., borough of Manhattan, under the laws, rules, and regulations of the forml of hulth of the department of health of the city of New York.

This permit is not transferable to any person or location other than above, and must be kept posted at all times in a conspicums place in this stora, and is revocable at the pleasure of the board.

By order of the board of health.

[Signed by the president and secretary.]

Form for milk-wagon permit, New York City, N. Y.

$39 \mathrm{G}-1899$.

Department of Health of the City of New York,

Borough of Manhattan,

Permit No.

New York, ......, 189..

..... residing at ...... borough of ...... is hereby authorized to sell fresh and condensed milk from wagon No. ...... in the city of New York, under the laws, rules, and regulations of the boarl of health of the department of health of said city. This permit is revocable at the pleasure of the board.

By order of the board of health.

......, Iresident.

......, Secretary.

Countersigned:

[Reverse side.]

This permit is roid if user for any wagn except the one dexignated on the face.

Driver's name .......

Residence.....

Borough of ......

NOT TRANSFERABLE.

Form for notification that license to sell milk must be secured.-Newton, Mass.

City of Nefyton, Departuent of Milk Inspection.

The public statutes provide (chapter $5 \%$, wection 4 ), that all persons before selling or offering for sale milk in any store, booth, stand, or market plate in any city must. be registered in the books of the milk inspector, and a license fee of fifty cents is required.

As you are reported as engaged in the sale of milk, and not registered, you are hereby notified that unless the provisions of the statute are complied with forthwith you will be complained of and liable to a fine not exceeding twenty dollars.

Please bring this notice with you.

Respectfully, Inspector of Milk. 


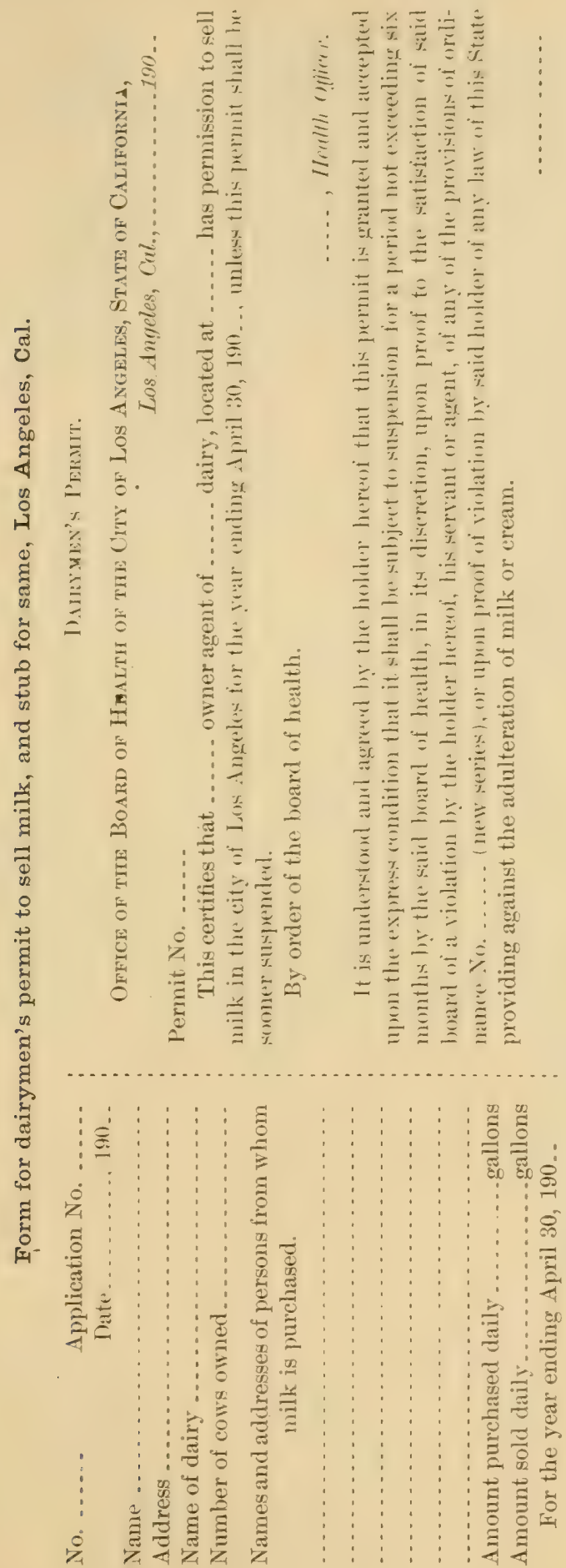




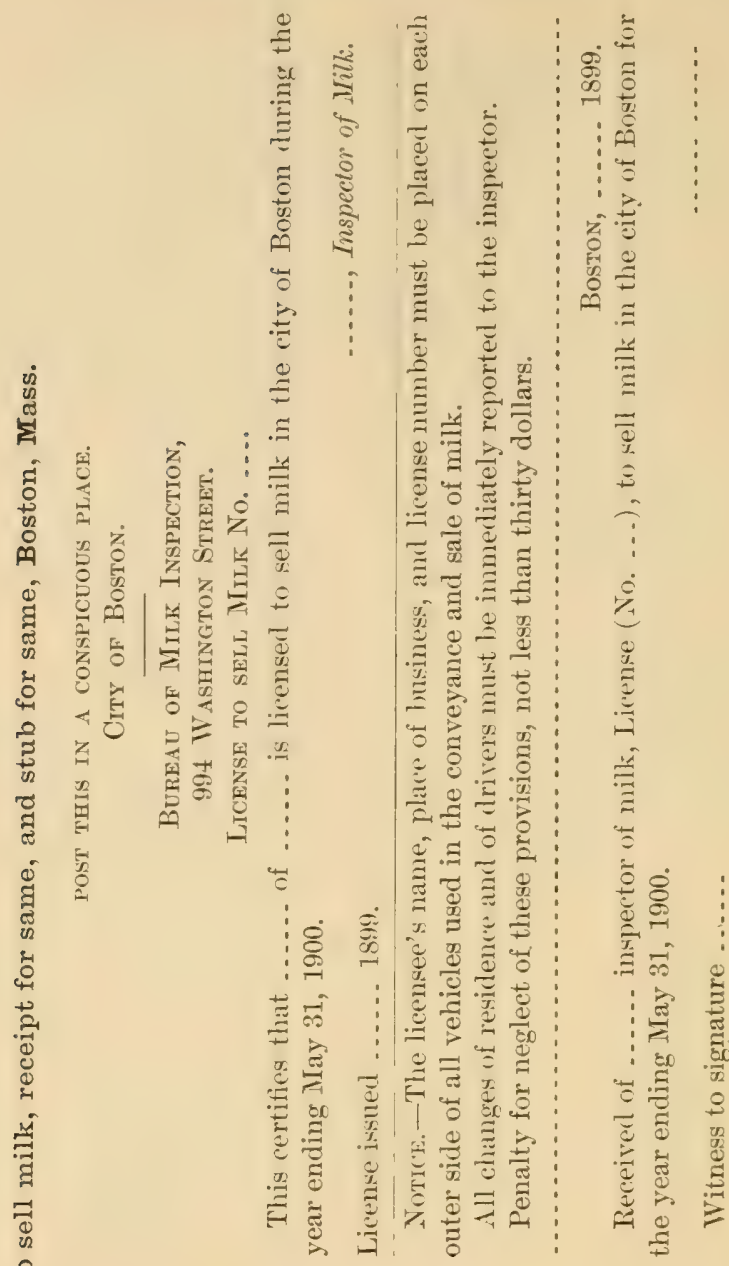

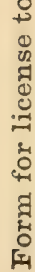

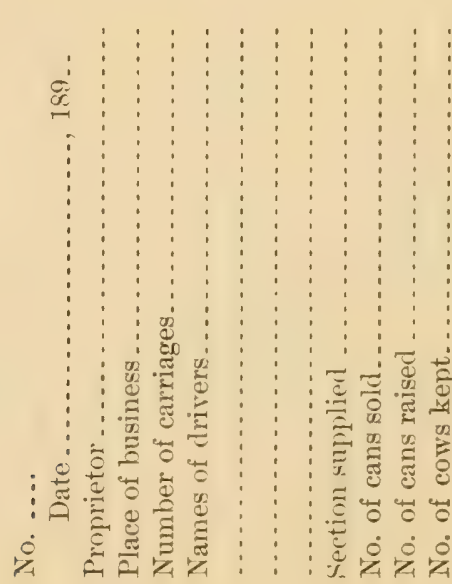


Form for notice to milk dealer to display license number on delivery wagons. Minneapolis, Minn.

(ORIGINAL.)

Mr.

Minneapolis, Minn., ..........., 190...

You are hereby notified that the law requires your name and location of dairy, with number of your city license, upon each vehicle used by you in selling milk.

Ten days' notice is hereby given you to comply with the law.

Inspector.

......, Commissioner of Health.

Forms for recording data regarding milk samples in Minnesota.

[Front.]

[Back.]

STATE DAIRY AND FOOD COMMISSION.

\section{Milk From Wagon.}

$$
\text { Date, ..........., } 189 \ldots
$$

Time......... m. ....... p. m.

Name on wagon......

Driver in charge......

Locality .......

Whether marked skimmed milk..... .

No. of cans on wagon......

Samples taken from.......qt. can.

License No.

No. on sample......

BABCOCK TEST.

Temp. ......

Specific gravity ......

Fat......

Sample delivered chemist.......189... ......, Inspector.
Anatysis.

Analysis No.

Specific gravity ...... .

Milk solids......

Not fat.....

Fat......

Ash......

Milk sugar......

Casein, etc. ......

Water:

Water added......

Color...... .

\section{REMARKS.}

Class

Note.-White cards are used for samples collected from wagons and yellow cards for samples collected from stores. 
Form for recording data regarding milk samples.-Worcester, Mass.

[This is printerl on the two sides of a thg, to he attached to the sample bottle.]

City of WORCEster.

MIIIK.

Agent.....

Date......

Time........ 10 ....... 1. m.

Town or city.....

street.....

$\dot{\text { I }}$ Name on wagon.....

License No.

Driver in charge

No. cants......

$\left\{\begin{array}{l}\text { Proprietor of store or restaurant..... } \\ \text { Of whom obtained } \ldots \ldots \\ \text { Time of delivery at store...... } \\ \text { Price sold at. .... }\end{array}\right.$

Sample taken from..... - quart can..... ...... marked "skimmed milk."

Other marks

Duplicate sample sealerd and deliverexd to

Receipt taken

Remilks.
City of Worcester. Milk Inspector's Departient, Room 2, City Hali.

Result of analysis:

Solids not fat. .....

Fat.....

Total sulicls.....

IVater.....

tiolor.....

Specific gravity ......

Cream by volume

Remarks.

Notified by postal of result of test. 
Form for recording data regarding milk samples.-Newark, N. J.

[An exact duplicate of this form is attached to it, one copy to be given to the person from whom the sample is taken, the other to be retained by the officer.]

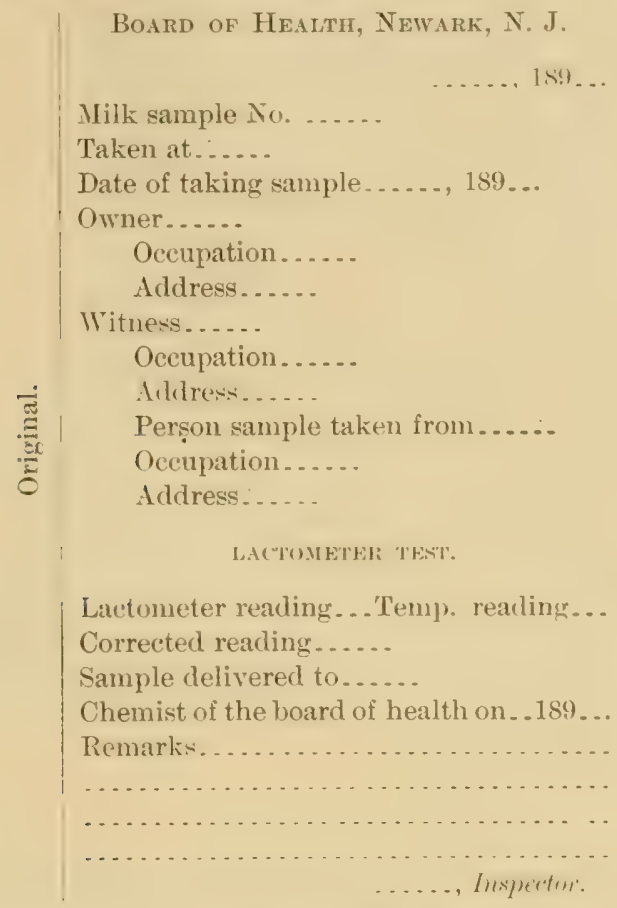

Form for recording data regarding preliminary inspections of milk, Philadelphia, Pa.

Date, ...... Hour, ......

Street and number,

Name of owner, ......

Business, ......

From whom purchased,

P. O. address,

\begin{tabular}{|c|c|c|c|c|c|c|}
\hline $\begin{array}{l}\text { Can } \\
\text { No. }\end{array}$ & $\begin{array}{c}\text { Amount } \\
\text { of } \\
\text { contents. }\end{array}$ & $\begin{array}{l}\text { Lactom- } \\
\text { eter. }\end{array}$ & $\begin{array}{l}\text { Temper- } \\
\text { ature. }\end{array}$ & $\begin{array}{l}\text { Lactom- } \\
\text { eter } \\
\text { at } 60^{\circ} \text {. }\end{array}$ & $\begin{array}{l}\text { Whole } \\
\text { milk. }\end{array}$ & $\begin{array}{l}\text { Skimmed } \\
\text { milk. }\end{array}$ \\
\hline 1 & & & & & & \\
\hline 2 & & & & & & \\
\hline 3 & & & & & & \\
\hline 4 & & & & & & \\
\hline
\end{tabular}

No. of inspection ......

Mark . on caul, . . . . .

REVARKS: 
Form for recording data regarding preliminary inspections of milk, Raltimore, IMd.

Health Department. Inspection of Milk at Railroad Stations.

Station.... Date..... Inspector......

No. of galls.... Whole M.... Skim M....

Cream......

In can

Marked\}......

Lact. reads ...... at ...... ${ }^{\circ} \mathrm{F}$. Action......

Form for notification of the taking of a sample, Newark, N. J.

To......

Department of Public Health, Newark, N. J., .....

Dear Sir: I liave taken a sample of milk for analysis from your store, ...... street, on this ...... day of ...... and divided said sample into two parts, and placed each part in a suitable ressel, duly sealerl and delivered, tendered at the time of such taking one part to you, ......., and in pursuance of the statute in such case made and provided (being the act of April 14, 1891). I deliver to you this statement in writing, and state that the cause of said sample having been taken is that the sair milk contains more than eighty-eight (88) per centum of watery fluids and less than twelve (12) per centum of milk solids.

Milk Inspector.

Form for reporting analyses of milk samples, Worcester, Mass.

[I'rinted on postal cards.]

City of Worcester, Department of Milk Inspechion, Room 2, City Hall.

As per the provisions of chapter 169 , acts of 1899 , we notify you that the samples taken from ...... have shown the following:

Fat, .......

Solids,

Cream by volume, .......

Specific gravity, .......

Milk Inspector.

Form to be attached to a can from which milk has been spilled, Baltimore, Md.

By Direction of the Healti Departanet of Baltimore City.

The ("ontents of this can have been exannined and found not to aceord with recpuirements of ordinance No. 87, approved May 16, 1894, and have therefore been destroyed under the provision of ordinance No. 130, approved July 9, 1894.

Gallons spilled ...... at ...... station. Date, ...... by ...... Inspector. 
Form for notice of condemnation of milk and stub for same, Philadelphia, Pa.

[Stub for blank below.]

Board of Health, Office of Chief Inspector of Milk. City Hall, Room 513.

No.

Philadelphia, ......, $190 \ldots$

...... quarts (gallons......) of milk condemned in the possession or custody of

Residence, ......

Sample delivered to......

....., Chief Inspector of Milk.

per ......., Asst. Inspector.

Bonid of Healiti. Oftice of Cimef Inspector of Mrlk. City Hall, Room 513.

No.

$$
\text { Ihiludelphin, ......, 191)... }
$$

I hereby certify that I have this day inspected and condemned ...... quants (gallons ......) of milk, in the possession or custody of ......, place of business, ......., and taken samples of same for examination and proof, one of which I have returned to said ......., as required by ordinance.

$$
\begin{aligned}
& \text { per ......., Chief Inspector of Milk. } \\
& \text { Ast. Inspector. }
\end{aligned}
$$

Form for recording inspection of milk depots, New Jersey.

Board of Health of the State of New Jersey. Record of Inspection of Milk Defot.

1. [Date of inspection.]...... 2. [Name of place.]...... 3. [Name of dealer.] ...... 4. [Street and number.]...... 5. How is the milk stored?..... 6. How are cans, bottles, and utensils washerl?..... 7. Any appliances for sterilizing can, bottles, and utensils?..... 8. Quantity of milk sold daily...... 9. Is can kept covered?..... 10. How is milk cooled?..... 11. Temperature of milk when sold..... 12. Where is the regular supply of milk obtained?..... 13. When short, where is the supply obtained?..... 14. How many persons handle the milk?..... 15. Are all in good health?...... 16. Date of last sickness on premises..... 17. Name of disease..... 18. Source of ice supply ..... 19. Source of water supply..... 20. Was sample taken for analysis? ..... 21. Marks...... 22. .......

Signature of Inspector.

Form for recording inspection of stores, etc., Fall River, Mass.

Office of the Board of Healti, Fall River, Mass.

Inspection of Storeas, Bootus, Stands, etc.

Where milk is received, held, kept, bottled, canned, stored, or offered for sale by Mr. ......, of ...... (Made in accordance with the demands of an ordinance ent1tled, "Relating to the sale of milk in the city of Fall River, Mass, and regulation No. 71 of the board of health of said Fall River.") Location of store, booth, or stand? 
Description of store, booth, or stand? ...... Description of bottling or canning room? ....... Is license to sell milk conspicuously posted? ...... Approximate quantity of milk sold daily? ...... Provision for keeping the milk from contamination? ...... Condition of receptacle in which milk vessels and measures are kept? ...... Condition of milk cans and other vessels used? ...... Condition of measures used? ...... General sanitary condition of store? ...... Sanitary condition of surroundings? ......

SOURCE OF MILK SUPPLY.

Name.

Address.

NAME ANI) ADIDRESS OF PERSONS TO WHOM MIIK IS IDELIVERED TO BE RESOLD.

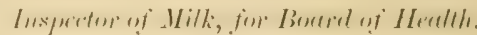

Form for record of inspections of wagons, etc., Fall River, Mass.

Office of the Board of Healti, Falu River, Mass.

INSPECTION OF WAgoNs, Venicles, etc.,

User to convey milk, or from which milk is sold or delivered by Mr. ......, of

(Made in accordance with the demands of an ordinance entitled, "Relating to the sale of milk in the city of Fall River, Mass, and regulation No. 71 of the board of health of said city." ) Number of license? ..... Is name of licensee and number of license painted on wagon according to regulation 71 ? ..... Is license carried on the wagon? ...... . Name and address of driver of wagon at time of inspection? ...... Approximate quantity of milk sold or delivered daily? ...... How much, if any, is sold to dealers to be resold? ...... Provision for keeping the milk from contamination? ...... Condition of receptacle in which milk vessels and measures are kept? ...... Condition of milk cans and other vessels used to hold milk? ...... Condition of milk measures and other utensils? ......

SOURCE OF MILK NUP'LY.

Name.

Address.

XAUE AND ADDRESG OF PERSONS TO WJOA MILK IS IDELIVEREI TO BE RFSOLD.

Inspected ....., $18 \ldots$ 
Forms for prohibiting and permitting the use of bottles, Yonkers, N. Y.

Office of the Board of Health,

Yoxkeтs, . .. Y........ 1 1s!...

Mr. .......

DEAr Sir: You are hereby notified that there is a case of ...... in the family of $\ldots . . . . . .$. street, and that, in pursuauce of article 14 , section 30 , of the sanitary code, you will he required to discontinue the furnishing of receptades for the delivery of milk into said family until you shall have heen notified hy this loard that the danger from contagion is passed.

Respectfully, , Milk Inspector.

11. I). Inersitent.

OFFICE OF THE BOARI) OF IIEATTIT, Yoxkens, X. Y......, 1s!...

Mr.

DeAr Sir: Permission is hereby given for the delivery of milk into the family of ............. street, in dealers' receptacles, as the danger from contagion on these premises has passed.

Respectfully, , Milk Inspertor.

M. I., President.

\section{Form for notification of violation of the law, Washington, D. C.}

Any objection to this notice should be tiled with the health ofticer before the expiration of the time allowed for making the changes specitied.

No. ......

Hehlei Depirthent, District of Colimbi.,

Dam axi Damy Farm Ixspertiox.

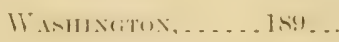

Mr. .....

Sin: Your attention is called to the following violations of the regulations for the govermment of dairies and dairy farms, which have been found to exist upon your premises:

You are hereby notified to correct the same within ..... days from the date of service of this notice.

By order of the health officer.

Inspector of Duiries and Intir?! Firms.

Form for warning against the sale of adulterated milk, Holyoke, Mass.

CitY of HoLYoke,

OfFice of INApector of Mitk, Correr of MaIx AND Mosmer Streets, No...... HOLYKE, . . . ., 190-.

You are hereby notified that a sample of ..... lusarked ......, recently obtained from you was found on analysis to be adulterated. You are respertfully warned that the obtaining of another such sample will be followed hy proserution acourding to law.

Respectfully, yours, Insprector.

$25839-$ No. $46-03-1 \div$ 
Forms for keeping the records of the milk inspector's office by the "card system," Providence, R. I.

Time,

MLK FROM NTORE.

Proprietor's name

No. Sample from

Milkman o. on sample can

Clerk Seal

Can narked skimmed milk Whether measure marked

Sample sealed and delivered to Collector Remarks Whether at all frozen

Name,

I)itte,

Aildress Anal. No.

Nilkman Taken from

Sp.

Milk sugar.

Fat Casein

Total Acirlity

S. N. F ("olor, etce - -

Ash

Remarks

No...... Nime

Places of hwiness.

Store.

bakery

Liestanrant

Lunch rart

Milkmen

Quantity week day

Whether eream is sold
Time delivered

Whether skimmed milk is sold

street.

The untersigned herehy makes application that his name be recomed in the inspector of milk's book as a milk dealer in the city of Providence, for the year ending February 1, 1901.

Signed

By

$\mathrm{O}$ 





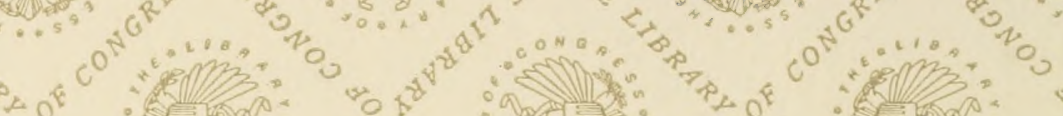

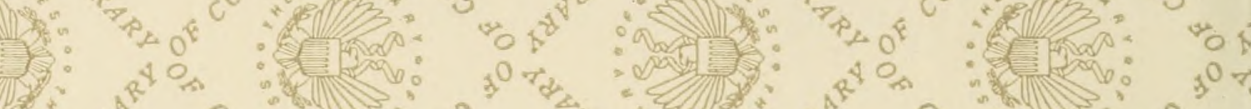
से कs of

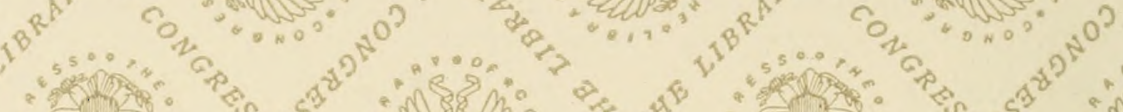

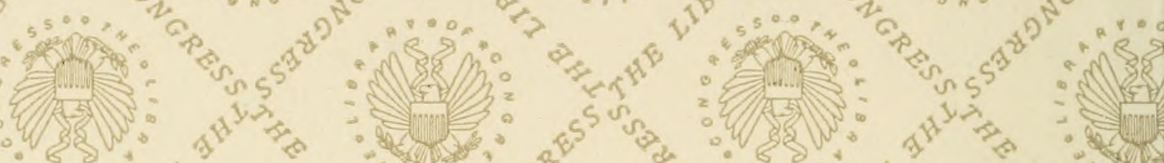
$0.040^{2}$ Ona

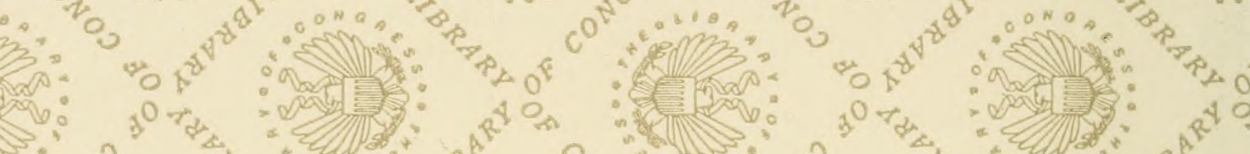

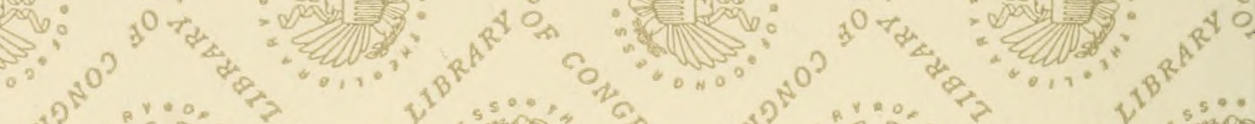
$5^{2}$ : की

2):

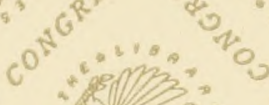

$40 \mathrm{O}$

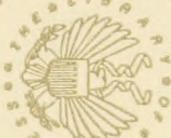

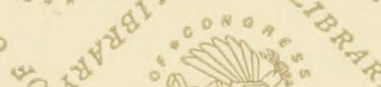

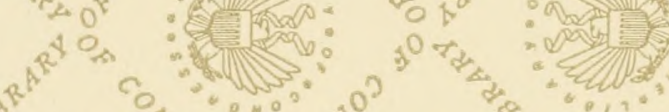

in 8900

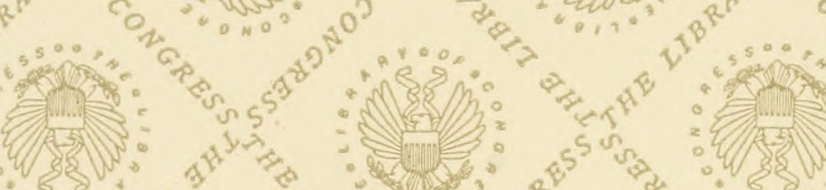
(4)

$\rho^{2}$

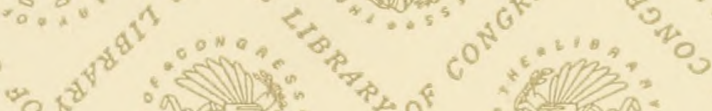

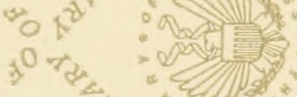

40

(e)

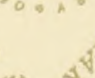

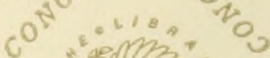

$\sin ^{50}$ 


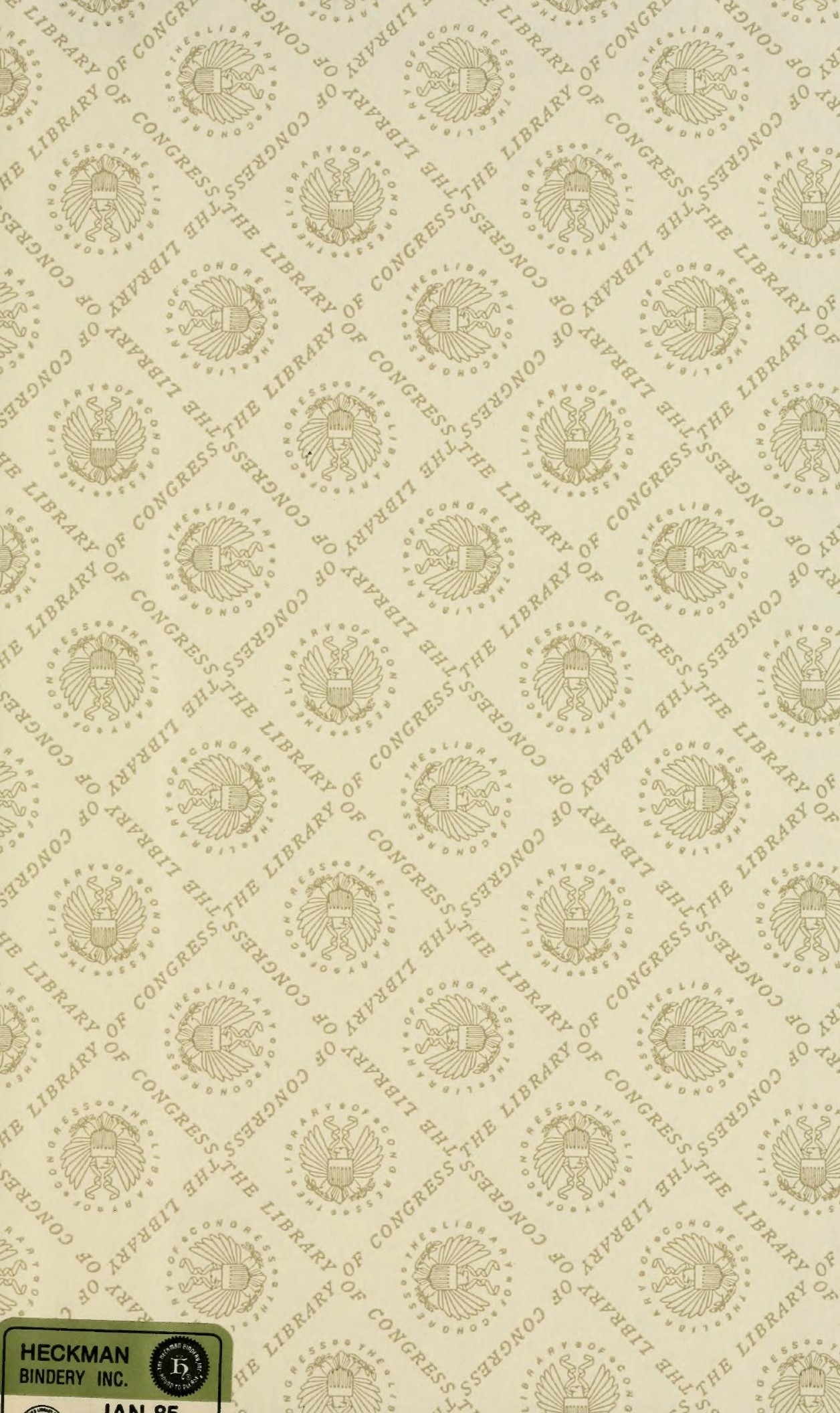


LIBRARY OF CONGRESS

||||||||||||||||||||||||||||||||||||||||||||

||||||||||||||||||||||||||||||||||||||||||||||||||||||| 00008959055 